\title{
Critiquing the Enlightenment: Beethoven's Music in Early Romanticism
}

\author{
Peter Tirrell D'Elia \\ Chatham, Massachusetts
}

Master of Arts, Tufts University, 2009
Bachelor of Arts, Harvard University, 2007

A Dissertation presented to the Graduate Faculty of the University of Virginia in Candidacy for the Degree of Doctor of Philosophy

Department of Music

University of Virginia

August 2016 
1. Introduction: Beethoven, Early Romanticism, and the Enlightenment Inheritance

2. Beethoven's "Bizarre Manner" and "Strange Difficulties": His Early Piano Sonatas as Critique of Enlightenment Reason

5. Recordings of Beethoven's Piano Sonata Op. 10, No. 2 in Context: A Comparison of Playing Style and Changing Notions about Beethoven's Compositional Style 


\section{Introduction}

\section{Beyond Binaries: Beethoven, Early Romanticism, and the Inheritance of the Enlightenment}

Today, Beethoven is often portrayed as a champion of the progressive Enlightenment and a foe of the regressive Romantics. However, those who hold this position rely on an anachronistic concept of Romanticism, one at odds with the Early Romanticism of Beethoven's young adulthood. The goal of this project is to show the implications of a more fine-grained understanding of Early Romanticism for the interpretation of Beethoven and his works. I present a series of musical analyses to illustrate this new understanding, examining works that have received less scholarly attention, including his early sonatas, his oratorio, and his Goethe songs. In addition, I analyze recordings of Beethoven's music in the 20th century to demonstrate the power that the traditional, binary-based understanding of Romanticism has continued to exercise in the performance practice of his work. This introductory chapter provides an overview of Early Romanticism, followed by a political history of Romanticism, and finally a discussion of how these politics have penetrated musicological scholarship.

\section{Revolutionaries or Reactionaries? The Early Romantics and the Enlightenment}

Rather than a single philosophy or politics, the first years of the Romantic movement encompass a variety of viewpoints often at odds with those of its later phases. Further complicating this is the fact that the beginnings of Romanticism are murky, and it was defined as a movement only in retrospect. Because of this, the claim that its early years constituted a movement at all has been disputed. ${ }^{1}$ However, some writings are often accepted to represent the

\footnotetext{
${ }^{1}$ Gerhard Schultz has written about the various emergences of the word "Romantic" toward the end of the eighteenth century. He points out that the idea of a "Romantic School" was first put into writing by its conservative
} 
beginnings of a Romantic movement. Among these, Friedrich Schlegel's (1772-1829)

formulation of Romantic poetry from 1798 stands out as one of the most prominent:

Romantic poetry is a progressive universal poetry. Its aim is not simply to reunite all the separate genres of poetry and for poetry to make contact with philosophy and rhetoric. It also wants to, and should, combine and fuse poetry and prose, inspiration and criticism, the poetry of art and that of nature; to make poetry lively and sociable, and to make life and society poetic, to poeticize wit, to fill and saturate the forms of art with decent educational material of every kind and to animate them with vibrations of humour. ${ }^{2}$

Because Schlegel, along with the group of literary critics and philosophers with whom he associated, seemed to be self-consciously developing a distinct philosophical and artistic program at this time, their writings from the end of the eighteenth century have come to be accepted as the seminal works of what we now consider Romanticism. Schlegel's group first came together in 1797, gathering to discuss politics, religion, philosophy, and art. First meeting in Berlin in the salons of Henriette Herz (1764-1847) and Rahel Levin (1771-1833), they later met at the house of August Wilhelm Schlegel (1767-1845) in Jena. The members of the group included the Schlegel brothers A.W. and Friedrich, Wilhelm Heinrich Wackenroder (17731801), Ludwig Tieck (1773-1853), Friedrich Wilhelm Joseph Schelling (1775-1854), Ernst Daniel Schleiermacher (1768-1834), and Friedrich von Hardenberg (1772-1801), known as Novalis. As a group, they represented a variety of intellectual pursuits and training: Schelling was a philosopher, A.W. Schlegel a literary critic, Schleiermacher a theologian, Novalis a poet

enemies in the first decade of the nineteenth century. These aesthetic conservatives, including Johann Heinrich Voss (1751-1826) and Jens Baggesen (1764-1826), resisted the Romantics' push to include medieval and modern literature and art along with the Greek and Roman classics and so grouped together a number of writers in the negatively polemical terms "Romantik" and "Romantische Schule." See Gerhard Schultz, "The Genesis of German Romanticism," in The Literature of German Romanticism, ed. Dennis F. Mahoney (Rochester, NY: Camden House, 2004): 33.

2 "Die romantische Poesie ist eine progressive Universalpoesie. Ihre Bestimmung ist nicht bloß, alle getrennten Gattungen der Poesie wieder zu vereinigen und die Poesie mit der Philosophie und Rhetorik in Berührung zu setzen. Sie will und soll auch Poesie und Prosa, Genialität und Kritik, Kunstpoesie und Naturpoesie bald mischen, bald verschmelzen, die Poesie lebendig und gesellig und das Leben und die Gesellschaft poetisch machen, den Witz poetisieren und die Formen der Kunst mit gediegnem Bildungsstoff jeder Art anfüllen und sättigen und durch die Schwingungen des Humors beseelen." Fragment no. 116, Kritische Friedrich-Schlegel-Ausgabe Vol. 2 (München: F. Schöningh, 1958): 182. 
and political theorist, Tieck and Wackenroder, novelists. The members from this time period are now often called the Frühromantiker, the Early Romantics.

Among the frequent topics under discussion in their salons were problems that had emerged in philosophical thought toward the end of the century. A major philosophical problem, following the writings of Immanuel Kant (1724-1804) and an event termed the "pantheism controversy" by historian of philosophy Frederick C. Beiser, was the realization that reason, followed to its conclusions, resulted first in skepticism and ultimately in nihilism. The pantheism controversy, which had begun as a dispute among the philosophers F.H. Jacobi, Moses Mendelssohn, and Gotthold Lessing, addressed this problem, centering on the question of whether reason must be not only ignored, but also rejected, in order to retain one's beliefs. The controversy pitted Jacobi, who rejected reason in order to preserve his beliefs, against Lessing and Mendelssohn, who argued for the necessity of adhering to reason even when it led to giving up certain beliefs. The Early Romantics came down on the side of reason, insisting on the individual's obligation to use his critical faculties to examine all aspects of life and the world and to live according to their conclusions. ${ }^{3}$

Kant's philosophical writings also addressed the problem of the limits of reason. In order to save the epistemological potential of reason, he argued that knowledge was constructed by the mind, and that while we cannot truly know reality, the "thing in itself" (ding-an-sich), our mental processes parallel the workings of reality and so give us an accurate portrait of it. His philosophy, while helping to rescue reason, also sharply circumscribed its power. The Early Romantics accepted Kant's epistemology and the more radical ideas of his follower Johann

\footnotetext{
${ }^{3}$ For more on the pantheism controversy, see Frederick C. Beiser, The Fate of Reason: German Philosophy from Kant to Fichte (Harvard University Press, 1987): 61-79.
} 
Gottlieb Fichte (1762-1814), which posits the reflective self as the origin of all knowledge, while applying their ideas to all critical writing. ${ }^{4}$ F. Schlegel and Novalis, maintaining that reason must provide a balance to the potential chaos of inspiration, ${ }^{5}$ concluded that the best way to do this was through radical criticism, in which reason must reflect upon and criticize even itself. As Richard Littlejohns writes:

What the Early Romantics rejected was not reason but what might be termed "pseudorationalism," that naïve empiricism practiced by the dictatorial critic and publisher Friedrich Nicolai (1733-1811) and fellow epigones of the Aufklärung in Berlin, who had debased rational debate into risible pedantry and utilitarianism. The "harmonisch Platten" (harmonious dullards), as both Friedrich Schlegel and Novalis call them, are a major target for the Early Romantics: those sober positivists who in their obsession with common sense and moderation "level out" and "harmonize" everything original, unconventional or paradoxical. The Early Romantics do not reject knowledge, just the opposite: extending the Aufklärung belief in human perfectibility, they insist that reasoned thought cannot stand still, but in an everlasting state of flux must question its own assumptions and build on them dialectically. ${ }^{6}$

As they were formulating their solution to the newly articulated limits of human reason, the Early Romantics also grappled with the destructive effects of the French Revolution. One consequence of post-Kantian philosophy, the result of its separation of the individual ego from knowable reality, had been the philosophical separation of the modern subject from the social and natural world. The French Revolution replicated this process of separation on a visceral

\footnotetext{
${ }^{4}$ Kant and Fichte's contributions are described in Azade Seyhan, "What is Romanticism, and Where did it Come From?" In The Cambridge Companion to German Romanticism, ed. Nicholas Saul (Cambridge University Press, 2009): 1-20.

${ }^{5}$ See Richard Littlejohns, "Early Romanticism," in The Literature of German Romantics (Camden House, 2004$): 61$.

${ }^{6}$ Littlejohns, 62. In addition, Azade Seyhan writes that "Romanticism has often been viewed as a critique of Enlightenment modernity and a paradigm shift that problematised the entire conceptual framework of the age. However, in the German context, Romanticism cannot be seen as a movement that reacted to and replaced the German Enlightenment. Rather, the intellectual thrust of the Romantic movement in Germany arose from the critical practice instituted by the Enlightenment itself" (emphasis added). Azade Seyhan, "What is Romanticism, and Where did it Come From?"
} 
level, further dividing and atomizing society. ${ }^{7}$ Thus, while the Early Romantics supported the principles of the Revolution, they also dealt with its divisive effects. As Azade Seyhan writes:

\begin{abstract}
Although the French Revolution, which Friedrich Schlegel regarded 'an almost universal earthquake' in the political order, was initially met with enthusiasm by German thinkers who yearned for a consolidation of Germany's discontinuous and fragmented political landscape, by 1794 it had come to represent the loss of a once whole world. German Romanticism's real and symbolic links to the French Revolution inhere both in the passion generated by ideals of equality, fraternity and freedom that resounded beyond French borders in 1789 and in mourning an irretrievably lost world of unity and harmony... Romanticism can thus be seen as originating in our human anxiety about the interlinked crises of the political turmoil that engulfed Europe and the limits of understanding introduced by Immanuel Kant's critiques. ${ }^{8}$
\end{abstract}

Thus, the Early Romantics attempted to find solutions to the political crisis provoked by the French Revolution as well as the philosophical problems resulting from the limits of human reason. Politically, they were moderates, neither revolutionaries nor reactionaries, who strove to formulate answers to some of the most difficult questions of the time. As Frederick Beiser writes:

There is indeed much in romantic political thought that remains attractive and that still deserves serious consideration today. The romantics insisted on the value of community; yet they never lost sight of the importance of individual liberty and self-realization. They stressed the value of tradition and history; but they did not lapse into the irrational defense of prejudice of Burke and De Maistre. They recognized the critical value of reason; but they never ignored its destructive consequences. ${ }^{9}$

The dual ambition to reunite the modern subject and to develop a philosophy and practice for critical reflection are two major strands of Early Romantic thinking that sets them apart from both the Aufklärer before them and the later Romantics after them. Unwilling to reaffirm the

\footnotetext{
${ }^{7}$ An elaboration of some of the problems that the Early Romantics found in some of the ideas and new social practices leading to the French Revolution, including egoism, materialism, and the division of labor, can be found in Frederick C. Beiser, Enlightenment, Revolution, and Romanticism: The Genesis of Modern German Political Thought, 1790-1800 (Harvard University Press, 1992): 233-35.

${ }^{8}$ Seyhan, "What is Romanticism, and Where did it Come From?"

${ }^{9}$ Beiser, Enlightenment, Revolution, and Romanticism: 223. Azade Seyhan comes to much the same conclusion about the concerns of the Early Romantics, writing that "German Romanticism's real and symbolic links to the French Revolution inhere both in the passion generated by ideals of equality, fraternity and freedom that resounded beyond French borders in 1789 and in mourning an irretrievably lost world of unity and harmony." See Azade Seyhan, "What is Romanticism, and Where did it Come From?"
} 
prejudice that some of their forerunners, including Joseph de Maistre and Edmund Burke, had insisted was necessary, the Early Romantics looked to the power of art as the means to achieve these goals. ${ }^{10}$ Art was reasonable, yet was also able to transcend reason's limitations. Unlike philosophy, which could only break apart, analyze, and critique, art had the ability to create and to unify. Friedrich Schlegel saw in art the potential to create a community, to reestablish a sense of belonging that philosophy and science had broken down. Part of its ability to bring people together into a larger community lay in its potential to educate, its Bildung. ${ }^{11}$ Bildung, the moral formation of the individual, had been a crucial goal for the ideal society of the Aufklärer, an importance that Schlegel retained in his own writing. ${ }^{12}$ In seeing in art the possibility of Bildung, Schlegel followed Friedrich Schiller (1759-1805), whose Über naive und sentimentalische Dichtung convinced the younger writer of the moral potential of modern art. But Schlegel went beyond Schiller, theorizing that the highest good to which art aspired, for the sake of Bildung, was the infinite, or the absolute. For Schlegel, the absolute consisted of freedom and equality for all, a balance of reason and nature, in the kingdom of God on Earth. And while the infinite could never be fully realized, it could be approached through constant striving. As Seyhan writes,

By emphasising Idealist philosophy's inability to grasp the absolute securely within a method, the early Romantics credit art with the power of representing the unrepresentable, in other words, to intimate the absolute that eluded all reason. As Friedrich Schlegel famously remarked, ['the absolute, because it is inexpressible, can only be expressed allegorically']...Romanticism came to view expressive freedom in life, writing and art as an end toward which humanity had to strive in order to rise above mere physical and natural existence." 13

\footnotetext{
${ }^{10}$ For more on de Maistre, see Carolina Armenteros and Richard A. Lebrun, eds., Joseph de Maistre and the Legacy of the Enlightenment (Oxford: Voltaire Foundation, 2011). For Burke on prejudice, see Edmund Burke, Reflections on the Revolution in France (Baltimore: Penguin Classics, 1986): 183-84.

${ }^{11}$ See Schlegel's Vorlesungun über Transcendentalphilosophie, from 1800, in Kritische Friedrich-Schlegel-Ausgabe.

${ }^{12}$ Because there is no English equivalent, I will refer to the writers of the German Enlightenment as the "Aufklärer."

${ }^{13}$ Seyhan, "What is Romanticism, and Where did it Come From?" For another elaboration on this idea, see Beiser, Enlightenment, Revolution, and Romanticism, 258-59. For more on the aestheticism of Early Romanticism, including an attempt to philosophically unite the post-Enlightenment period using the impact of the French
} 
Thus, the Early Romantics looked optimistically to art to encourage critical reflection and as a potential source of meaning for the disenchanted modern subject. For them, art offered the potential for moral development and improvement, whose fulfillment was to be hoped for in the future. This sense of optimism, which was shared between the Early Romantics and the Aufklärer, further separates Early Romanticism from its later manifestations, which eventually gave in to pessimism. The turning point between optimism and pessimism, according to both Richard Littlejohns and Nicholas Saul, lay between 1800 and 1810, when "a snowballing sense of disenchantment and disillusionment" finally turned into a realization of "the foundationlessness of human convictions."14

\section{Romanticism: A Political History}

Despite the commitment of Schlegel and the Frühromantiker to freedom, reason, and individuality, throughout the $19^{\text {th }}$ and $20^{\text {th }}$ centuries, Romanticism has often been portrayed as a backward, fundamentally conservative movement, committed instead to authoritarianism and irrationality. A short history of politicized and appropriated Romanticism will help us to understand why it is still often understood in this way. ${ }^{15}$ This understanding of Romanticism can be traced to the 1820s, when Johan Wolfgang von Goethe (1749-1832) famously uttered

\footnotetext{
Revolution and the idea of secularization, see Nicholas Saul, "Aesthetic Humanism (1790-1830)," in The Cambridge History of German Literature, ed. Helen Watanabe-O'Kelly (Cambridge: Cambridge University Press, 1997): 202-71. ${ }^{14}$ Richard Littlejohns, "Crossing a Threshold: The Example of German Romanticism," in Schwellen: Germanistische Erkundungen einer Metapher, eds. N. Saul, D. Steuer, F. Möbus (Würzburg: Königshausen \& Neumann, 1999): 15263. Nicholas Saul, "Aesthetic Humanism (1790-1830)."

${ }^{15}$ This discussion is a synthesis of my own readings along with those of Beiser, Enlightenment, Revolution, and Romanticism, 222-27.
} 
"Classicism is health, Romanticism is sickness" (Klassisch ist das Gesunde, romantisch das Kranke), a maxim that was published posthumously. ${ }^{16}$

In the 1830s, German liberal thinkers attacked Romanticism for its political conservativism, as well as the association of its leaders with Klemens von Metternich (17731859), the Austrian statesman who heavily censored and spied on his citizens. The most prominent of these liberals was Heinrich Heine (1797-1856), who portrayed Romanticism in his Die romantische Schule (1833) as a reactionary movement, writing that it was "nothing else than the reawakening of the poetry of the Middle Ages. ${ }^{, 17}$ Heine considered Romanticism to be an aesthetic reaction to Classicism, but also a political reaction to the French revolution and modernity as a whole. By aligning its aesthetics with what he branded its backward politics, Heine also set the stage for Romanticism's future association with repressive politics. Fellow German liberal Arnold Ruge (1802-1880) followed Heine's lead in 1844 with his Deutschfranzösische Jahrbücher, in which he associated the Romantics with the "Christian-German restoration principle. ${ }^{\prime 18}$ On the other side, the later Romantic Eichendorff embraced this characterization, writing in 1846 in his Geschichte der neuern romantischen Poesie in Deutschland that the Early Romantics were "knights of Christendom waging war against prevalent rationalism in youthful, fiery inspiration." 19

Heine and Ruge have some justification for their arguments. Friedrich Schlegel, an important member of the Early Romantic movement, evolved into a conservative who worked with Metternich as he aged. Some of the younger Romantics at the time adopted conservative

\footnotetext{
${ }^{16}$ Johann Wolfgang von Goethe, The Maxims and Reflections of Goethe, trans. Bailey Saunders (New York: Macmillan, 1906): 166.

${ }^{17}$ Heinrich Heine, Die romantische Schule, Kritische Ausgabe, ed. H. Weidmann (Stuttgart, 1976), 10.

${ }^{18}$ Arnold Ruge, "Plan der Deutsch-französische Jahrbücher," in Werke (Mannheim, 1848), IX, 145-160.

${ }^{19}$ Joseph von Eichendorff, Sämtliche Werke: Historisch-kritische Ausgabe, edited by Wolfram Mauser (Regensburg: Habbel, 1962), 8.1: 22. Cited in Littlejohns, "Early Romanticism," 61.
} 
views as well, expressing their support for the unity of church and state and a strict social hierarchy. However, there are two lingering problems with Heine and Ruge's influential views. First, they establish over-simplified, politicized binaries between Classicism and Romanticism, drawing a connection between Classicism and progressive thinking, and between Romanticism and regressive thinking. As historian of philosophy Frederick C. Beiser writes:

While the classicist is a humanist who thinks that the end of humanity is realized only here on earth, the romantic is a Christian who believes that this end is fulfilled only in heaven. The basic authority of the classicist is reason, while that of the romantic is faith. And whereas the political ideal of the humanist is freedom and self-realization, that of the romantic is subordination to church and hierarchy. ${ }^{20}$

Beyond simplistic binaries, the second problem with Heine and Ruge's descriptions is anachronism. The Romantic movement began as a small group of young German literary intellectuals in Jena in the late 1790s. It had evolved significantly over the course of the decades, often in direct contradiction to earlier manifestations. Heine and Ruge characterized the entire movement without taking into account this development. The accuracy of their description is thus dependent upon the Romanticism of the 1830s, and applies little to its early phase at the turn of the 19th century.

Despite, or perhaps because of, their oversimplified account, Heine and Ruge's binary stuck, and more than a century later we can still find evidence of its politicization. Thus, in 1972, the eminent British scholar T.J. Reed's survey essay on the "Goethezeit" characterized German Romanticism, in contrast to Goethe and Schiller's Classicism, as essentially backward, "a premature undermining of great gains, an unnecessary reversion to immaturity, revolution by

\footnotetext{
${ }^{20}$ Beiser, Enlightenment, Revolution, and Romanticism, p. 224.
} 
retrogression." Reed's diagnosis pointed to all aspects of the movement, including "its aesthetic, philosophical, religious, social and political tendencies." 21

Earlier in the twentieth century, a similarly politicized distinction was formulated between Romanticism and the Enlightenment. Some of the Nazis adopted Romanticism for their own uses, contrasting it with the Enlightenment rather than with Classicism. Nazi writer and editor of the Zeitschrift für Deutschkunde Walther Linden, for example, traced the intellectual genealogy of the Nazis back to the Romantics. In a journal article from 1933, "Reassessment of German Romanticism” (Umwertung der deutschen Romantik), Linden argued that Romanticism is the source of all of the goals and ideals of National Socialism. Linden also contrasted Romanticism with the Enlightenment, not with Classicism as Heine and Ruge did, equating the former with an orderly communitarianism palatable to the Nazis and the latter with a dangerous individualism. $^{22}$

Linden's ideas, including his opposition of Romanticism to the Enlightenment and his appropriation of Romanticism into the intellectual genealogy of the Nazis, also appear on the other side of the political spectrum in the writings of American academics. The intellectual historian A.O. Lovejoy (1873-1962) traced a line between Romanticism and Nazism in his 1941 article "The Meaning of Romanticism for the Historian of Ideas," ${ }^{23}$ while also using Linden's distinction between the Enlightenment and Romanticism. He identified three important ideas of Romanticism — organicism, dynamism, and diversitarianism — which were distinct from those of the Aufklärung. He then theorized an inevitable development of these ideas that draws a straight

\footnotetext{
${ }^{21}$ T.J. Reed, "The 'Goethezeit,"” in Germany: A Companion to German Studies, ed. Malcolm Pasley (London: Methuen, 1972), 516.

${ }^{22}$ Walther Linden, “Umwertung der deutschen Romantik," Zeitschrift für Deutschkunde 47(1933): 243-75.

${ }^{23}$ A.O. Lovejoy, "The Meaning of Romanticism for the Historian of Ideas," Journal of the History of Ideas 2/3 (June 1941): 257-78.
} 
line from Romanticism to Nazism, what he called "a certain specific historical connection between the intellectual revolution of the Romantic period and the tragic spectacle of Europe in $1940 ., 24$

The problem here is not so much the inaccuracy of the blanket characterizations of the Romantics as it is the arbitrariness of the historical theorizing. Linden, realizing that there was too great a contrast between early and late Romanticism to ignore, drew a distinction between the individuality and aestheticism of its early iteration with the religion and communitarianism of later Romanticism. He then decided that the later version was the essence of Romanticism, apparently arbitrarily. Lovejoy committed an historical fallacy of causation, establishing a chain of events in his history of ideas to draw the line backward from Nazism to Romanticism, then portrayed it as a line forward, from Romanticism to Nazism.

This politicized polarization between the Enlightenment and Romanticism has remained a strong undercurrent in scholarship. Perhaps the most obvious example of this can be seen in the debate about the existence of a "Counter-Enlightenment," a term which designates an explicitly reactionary mode of thought, contemporary with the Enlightenment and representing the intellectual precursor to Romanticism. ${ }^{25}$ The stakes of this debate, which are remarkably similar to those of the Classicism/Romanticism and Enlightenment/Romanticism contests, were laid out most powerfully over the career of the intellectual historian Isaiah Berlin (1909-1997), who identified certain eighteenth-century thinkers as enemies of the Enlightenment. One of these, J.G. Hamann (1730-1788), he characterized thus:

\footnotetext{
${ }^{24}$ Ibid, 278.

${ }^{25}$ For a survey of this debate, see Joseph Mali, et al. "Isaiah Berlin's Counter-Enlightenment," Transactions of the American Philosophical Society 93/5 (2003).
} 
The most passionate, consistent, extreme and implacable enemy of the Enlightenment and, in particular, of all forms of rationalism of his time (he lived and died in the eighteenth century) was Johann Georg Hamann. His influence, direct and indirect, upon the romantic revolt against universalism and scientific method in any guise was considerable and perhaps crucial [italics added]. ${ }^{26}$

In this first paragraph of his book on Hamann, Berlin draws the starkest of divides between Hamann and the Enlightenment, and also builds an affinity between this "enemy" and Romanticism. The dividing line comes in familiar terms of the regressive and repressive: for Berlin, Hamann is an enemy of "all forms of rationalism" as well as science. He is also a divider of people, who just like the Romantics is "against universalism."27

More recently, the idea of the Counter-Enlightenment has come to be used ever more explicitly as a term that designates a reactionary mode of politics, in journalism as well as in academic writing. In an article about Isaiah Berlin's role in helping to disseminate the idea of the Counter-Enlightenment, Germanist Robert E. Norton notes that a 2004 New York Times article connects the Counter-Enlightenment to radical Islam. Norton goes on to show that the idea of the Counter-Enlightenment originated in German Nationalist writings from the early twentieth century, whose exponents valued an "irrationalism" led by Hamann and Herder against the "calculating, measuring, appraising understanding" of the Enlightenment. ${ }^{28}$ As Norton wrote in 2007:

As an explanatory paradigm, if not in actual name, the "Counter-Enlightenment" came into existence much later than the Enlightenment itself and was part of an ideological program carried out in the guise of historical analysis. It did not arise as a merely neutral designation, a value-free explanatory term. It was, rather, a fundamentally partisan

\footnotetext{
${ }^{26}$ Isaiah Berlin, The Magus of the North: J.G. Hamann and the Origins of Modern Irrationalism, (John Murray: 1993), 1.

${ }^{27}$ For a discussion of the historical validity of Berlin's characterizations of Hamann and other CounterEnlightenment figures, see Frederick Beiser's "Berlin and the German Counter-Enlightenment," Transactions of the American Philosophical Society 93/5 (2003): 105-116.

${ }^{28}$ Robert E. Norton, "The Myth of the Counter-Enlightenment," Journal of the History of Ideas 68/4 (October 2007): 654-55. Norton identifies these ideas in the writings of German nationalists Herman Nohl and Rudolf Unger. These quotes are taken from Unger's book, Hamann und die Aufklärung (Jena: Eugen Diederichs, 1911), 235-36.
} 
construct from the very beginning, one designed to shape the present through an activist, which is to say ideologically biased, reading of the past. At its inception, the notion of the Counter-Enlightenment, which seems merely to describe contemporary, that is eighteenth-century, opposition to the Enlightenment, was in fact fashioned as a weapon in a twentieth-century campaign to destroy it. ${ }^{29}$

The "ideological program" to which Norton refers is that of the German nationalists. Norton also points out that the term Counter-Enlightenment was a later coinage, but that its exponents, most prominently Isaiah Berlin, adopted the same language and positions as the earlier German nationalists while leaping to the other side of the ideological divide.

We now have three politicized binary oppositions which have surfaced at different times, but all of which represent nearly identical ideological stances and use nearly identical language. While the politics of the Counter-Enlightenment are plain to see today, the more subtle politicization of Classicism, the Enlightenment, and Romanticism has often lain hidden under a layer of coded rhetoric. This rhetoric has used terms which, to today's liberal academic, favor Classicism and the Enlightenment over Romanticism and the Counter-Enlightenment. When the debate is cast as a progressive, reasonable and freedom-loving Enlightenment against a reactionary, irrational, and repressive Romanticism, the Enlightenment always wins. The influence of this rhetoric on musicological writing is evident in an otherwise brilliant article by Maynard Solomon, who outlines the history of the oversimplified binary, but who nonetheless uses the same stigmatizing language as Berlin about the Early Romantics. He writes, for example, of their interest in "the irrational," and rightly associates them with reason but also with “the darker currents of existence." Solomon also acknowledges the problems of Beethoven's

\footnotetext{
${ }^{29}$ Ibid. Norton notes the "creeping institutionalization" of the term, citing Darrin McMahon's Enemies of the Enlightenment: The French Counter-Enlightenment and the Making of Modernity (New York: Oxford University Press, 2001), whose title was modeled from Berlin's book on Hamann, and Graeme Garrard's Rousseau's CounterEnlightenment: A Republican Critique of the Philosophes (Albany: State University of New York, 2003), both written in the new millennium.
} 
participation in the Classical-Romantic framework and especially his association with

Classicism, writing that "the unrelenting view of Beethoven as a classicist has tended to close off serious consideration of his intellectual and musical receptivity to post-classical and postEnlightenment ideas and imagery.", 30

In much musicological discourse, however, the politics of the binary have been mostly missed, while its language and principles are still used to describe musical styles. The "Classical" entry in the Grove Encyclopedia, for example, describes the term in various ways and includes some of its history, but fails to address the history of its politics. And while Maynard Solomon and Scott Burnham are two writers who have recognized the history of the Classical and Romantic dispute as it has taken place within music discourse, they have not recognized its stigmatizing language or the broader politics to which the terms refer. While the existence of such a politics might be unremarkable, even expected, what is most noteworthy is its almost complete invisibility in writing on the subject. Whether or not they recognize it, musicologists have been working within this politicized binary. ${ }^{31}$

This brings us to Beethoven, who has straddled the divide for so long. Cast as a Romantic by E.T.A. Hoffmann and Richard Wagner in the nineteenth century, Beethoven was reformulated as a Classicist in the twentieth century, a composer whose music exemplified formalist principles. ${ }^{32}$ Charles Rosen's The Classical Style: Haydn, Mozart, Beethoven from 1971 most powerfully expresses this viewpoint. He writes of the symmetry, balance, and clarity of his

\footnotetext{
30 See Maynard Solomon, "Beethoven: Beyond Classicism," in The Beethoven Quartet Companion, Robert Winter and Robert Martin, eds. (Berkeley: University of California Press, 1994): 59-76.

${ }^{31}$ See Maynard Solomon, "Beethoven: Beyond Classicism"; and Scott Burnham, "The Four Ages of Beethoven: Critical Reception and the Canonic Composer," in The Cambridge Companion to Beethoven, ed. Glenn Stanley (Cambridge: Cambridge University Press, 2000): 272-91.

32 Burnham, "The Four Ages of Beethoven."
} 
Classical style, presenting it as a unified aesthetic with a "logical coherence." ${ }^{, 33}$ As formalism ran into its ideological critics, however, Beethoven's music began shifting out of its purview. Instead, the composer has more recently been migrating to the Enlightenment. As Scott Burnham's “Beethoven: Posthumous Influence and Reception" entry in the Grove Encyclopedia notes, "[Kinderman and Solomon] argue strongly against the persistent notion of Beethoven's music as a timeless aesthetic force, [that is, Rosen's formalist Classicism], agreeing instead that it performs specific cultural work". This specific cultural work is nothing other than "the nature of [Beethoven's] relation to Enlightenment thought." But as we have seen, in turning from Classicism to the Enlightenment, Solomon and Kinderman do not necessarily overcome the underlying politics. In fact, in their writings on Beethoven, these scholars retain the political binary that I have outlined above, utilizing the same imagery of Enlightenment progress, freedom, and reason against Romantic regression, irrationality, and repression.

The association of Beethoven with the Enlightenment supplants his Classicism, yet retains its politics. Maynard Solomon's biography Beethoven from 1977 emphasizes the composer's receptivity to Enlightenment ideas, including “the ideals of fraternity, freedom of thought, social justice, and moral improvement," turning to Heine's writings for support of his claims. ${ }^{34}$ William Kinderman's monograph, Beethoven, seeks to connect the composer to a broader historical context, arguing that his music must be understood beyond "a merely personal or national style." Kinderman's answer is "Beethoven's deep roots in the Enlightenment,"35 a term which he connects to concepts of freedom and progress, peppering references to such ideals while referencing the Enlightenment throughout his biography. He also connects all of these,

\footnotetext{
${ }^{33}$ Charles Rosen, The Classical Style: Haydn, Mozart, Beethoven, (New York: The Viking Press, 1971): 57-63.

${ }^{34}$ Maynard Solomon, Beethoven, (Schirmer Books, 1977): 52-53.

${ }^{35}$ William Kinderman, Beethoven (Berkeley: University of California Press, 1995): 3.
} 
along with Beethoven, to a secular humanism that he contrasts to religious dogma. ${ }^{36}$ In the 2006 edition of A History of Western Music, Grout, Palisca, and Burkholder follow these writers, pointing out that Beethoven "was aware of Enlightenment ideals." ${ }^{37}$ Most recently, Jan Swafford's Beethoven: Anguish and Triumph continues to distance Beethoven from Romanticism, writing that "Beethoven, for his part, did not share that spirit; he never really absorbed the Romantic age." 38 He also draws much of the same contrast between the Enlightenment and Romanticism:

If the resonating ideas of the Enlightenment were reason, truth, nature, order, and objectivity, those of the coming Romantics would be the subjective, the instinctive, the uncanny, the sublime, and nature in its great and terrible face... The Aufklärung looked to a radiant future of social and scientific perfection; the Romantics looked to the fabled, mysterious, unreachable past. The eighteenth century longed for freedom and happiness. The nineteenth century was caught up not in longing toward an end but in longing for the delirium and pain of longing itself. ${ }^{39}$

Carl Dahlhaus also places Beethoven in a pre-Romantic context while addressing the new aesthetics of the Early Romantics in his The Idea of Absolute Music. He argues that their new aesthetic paradigm for music, articulated by Tieck and Wackenroder, precedes any repertory for which it fits. Instead, Dahlhaus argues that E.T.A. Hoffmann's writings on Beethoven's later music define the first truly Romantic music, over a decade after the writings of Tieck and Wackenroder: “...Tieck's metaphysics of instrumental music, which was originally coined in response to works by Johann Friedrich Reichardt, did not find an adequate object until E.T.A.

\footnotetext{
${ }^{36}$ ibid, 128-130, 302-303, and especially 307. Secular humanism against religious dogma is yet another aspect of the politicized opposition that is the focus of this chapter. The idea that Beethoven stands for secular humanism against religion has its own history, and Solomon also draws this contrast in his biography. See Solomon's Beethoven, 53-54. For a discussion of the history of Beethoven as a secular humanist, see Ruth Solie, "Beethoven as a Secular Humanist: Ideology and the Ninth Symphony in Nineteenth-Century Criticism." In Explorations of Music, the Arts, and Ideas: Essays in Honor of Leonard B. Meyer, eds. Eugene Narmour and Ruth A. Solie (Stuyvesant, NY: Pendragon Press, 1988): 1-42.

${ }^{37}$ Donald J. Grout, Claude V. Palisca, and J. Peter Burkholder, eds., A History of Western Music, 7th edition (New York: W.W. Norton, 2006): 571.

38 Jan Swafford, Beethoven: Anguish and Triumph (New York: Houghton Mifflin Harcourt, 2014): 51.

${ }^{39}$ Ibid, 53.
} 
Hoffmann borrowed Tieck's language in order to do justice to Beethoven. ${ }^{״ 40}$ By taking this tack, Dahlhaus avoids having to consider how the music written in the years surrounding the turn of the nineteenth century might align with Early Romantic writings, and thus perpetuates the divide between the progressive Enlightenment and regressive Romanticism.

Some recent studies have placed Beethoven in new, post-Enlightenment contexts. In his Beethoven After Napoleon: Political Romanticism in the Late Works, Stephen Rumph proposes a new relationship between late Beethoven and the politics of his time. While the later works have often been seen as the product of a reclusive Beethoven who set himself apart from the world, Rumph argues that they actually correspond to the conservative political Romanticism espoused by the later writings of Friedrich Schlegel and Adam Müller. ${ }^{41}$ Similarly, Nicholas Mathew has argued against the lopsided association of Beethoven with the Enlightenment. Mathew's book, Political Beethoven, reconsiders Beethoven's explicitly political compositions, many of which have often been relegated to the margins of his output because of their incompatibility with a formalist aesthetic paradigm. In writing on the numerous aesthetic dismissals of his wartime compositions, Mathew notes that "in the context of scholarship that continues to promote an image of Beethoven as a lifelong Enlightenment radical (despite much evidence to the contrary), these wartime compositions appear to be uncomfortable or perhaps merely judicious ideological compromises — examples of an artist allowing himself to be swept along by history." ${ }^{42}$

\footnotetext{
${ }^{40}$ Carl Dahlhaus, The Idea of Absolute Music, trans. Roger Lustig (Chicago: University of Chicago Press, 1989): 90. Writing on this subject, Mark Evan Bonds notes that other, earlier authors put forth the same thesis: "See Hugo Goldschmidt...where Wackenroder is called 'a prophet' whose theories 'do not fit any music of the time'..." See Bonds, "Idealism and the Aesthetics of Instrumental Music at the Turn of the Nineteenth Century," Journal of the American Musicological Society 50 2/3 (Summer-Autumn 1997): 389, note 6.

${ }^{41}$ Stephen Rumph, Beethoven after Napoleon: Political Romanticism in the Late Works, (Berkeley: University of California Press, 2004): 2-6.

${ }^{42}$ Nicholas Mathew, Political Beethoven, (Cambridge: Cambridge University Press, 2013): 6.
} 
Like the writings of Rumph and Mathew, this dissertation assumes that Beethoven's music resonates with the political philosophies of his time and can be fruitfully explored as such. However, while these writers largely adopt the politics of a regressive Romanticism in the context of Beethoven's later works, here I explore a positive alternative in the complexities of Early Romantic writing, proposing that even Beethoven's early music shares much with the concerns of the Early Romantics. Taking this view opens up previously understudied works, like his oratorio Christus am Ölberge and his Goethe songs, to contextual analysis which leads to a deeper understanding of their historical position and a deeper appreciation of their aesthetic richness. Like the writings of the Early Romantics, Beethoven's art acts as a medium for selfreflection and self-criticism, points the way toward a sense of unity and meaning for the alienated modern subject, and expresses an optimism that acknowledges pain and suffering.

The chapters proceed in chronological order, beginning with the 1790s, through the early years of the first decade of the 1800s, and concluding with songs from later in that decade. Chapter 1 deals with the early sonatas, showing how they can be read to share common concerns with the literary Frühromantiker. These concerns include a skepticism with the perspicuity of language and a commitment to exposing the artifices of their respective arts-novels, plays, and poetry for the Frühromantiker, and music for Beethoven. Chapter 2 turns to Beethoven's only oratorio, Christus am Ölberge, comparing it to that of the Enlightenment oratorio Der Tod Jesu by C.H. Graun. This chapter explores the figure of Jesus in each, exposing the fault line running between Enlightenment-era oratorio and Beethoven's more individualistic, alienated view of society. Chapter 3 delves into Beethoven's songs, particularly those of Goethe, to see how Beethoven interprets the meaning of Goethe's poetry through his music, and how far he is 
removed at this point from Enlightenment song. Chapter 4 explores the legacy of the ClassicalRomantic binary through recordings of Beethoven's piano sonatas. 


\section{Beethoven's "Bizarre Manner" and "Strange Difficulties": His Early Piano Sonatas as Critique of Enlightenment Reason}

In the Allgemeine Musikalische Zeitung of 9 October 1799, the article on Beethoven's Op. 10 set of piano sonatas expresses ambivalence. On the one hand, the composer is "a man of genius, has originality, and goes entirely his own way." On the other, Beethoven's "abundance of ideas...too often still causes him to pile up ideas without restraint and to arrange them by means of a bizarre manner so as to bring about an obscure artificiality or an artificial obscurity..." Similarly, in an 1803 review of his Op. 31 set of piano sonatas, the reviewer complains that "some themes are brought forth without any connection. Thus, instead of one totality, they contain three to four totalities that have either a ridiculous or no relationship at all to each other," adding that the sonatas are "occasionally bizarre." In 1798, composer and critic W.J. Tomaschek attended a concert in which Beethoven played. His notes on the concert include the following: Beethoven's "frequent bold leaps from one motive to another, whereby organic association, a gradual development of ideas, is disrupted...Not infrequently, the impartial listener is violently dislodged from his supremely blissful mood. ${ }^{4344}$

Charges of excessive difficulty were also common in the reviews from Beethoven's early career, adding to those of obscurity. In a review from 1799, the writer opines that:

...these quite peculiar sonatas, overladen with strange difficulties..." "It is undeniable that Mr. van Beethoven goes his own way. But what a bizarre, laborious way! Studied, studied, and perpetually studied, and no nature, no song...There is obstinacy for which we feel little interest, a striving for rare modulations, a repugnance against customary

\footnotetext{
${ }^{43}$ Only the first two sonatas of the set were published at first, in 1803. The three were published together in 1804. Wayne M. Senner, et al, eds., The Critical Reception of Beethoven by His German Contemporaries, Vol. I (Lincoln: University of Nebraska Press, 1999), 187. For more examples of common criticisms of Beethoven, see p. 164, from 1803: “Impartial connoisseurs were not as pleased with Beethoven's most recent fortepiano works that, they perceived, conspicuously strove to be unusual and original, only too often at the cost of beauty."

${ }^{44}$ The Critical Reception of Beethoven by His German Contemporaries, Vol. I, 135.
} 
associations, a piling on of difficulty upon difficulty so that one loses all patience and enjoyment." 45

Though his early reviewers objected to the difficulty of his compositions, Beethoven himself strongly valued the idea, writing that "what is difficult is also beautiful, good, great and so forth," and that calling a work difficult is "the most lavish praise that can be bestowed."46

While modern scholarship tends to ignore such reviews, the objections raised in them provide us with more than colorful musical invective; they allow us a window into the quickly changing aesthetic theory of the time. In fact, the difficulty and obscurity of some of Beethoven's early sonatas actually accord with the emerging early Romantic aesthetic, which was being formulated as the eighteenth century drew to a close. In the space of just a few years, this aesthetic reversed prevalent notions of what constituted legitimate artistic practice. Much maligned by Enlightenment art critics, the concepts of difficulty and obscurity were reappraised, becoming highly valued by Beethoven's Romantic contemporaries Friedrich Schlegel (17721829) and Ludwig Tieck (1773-1853). These philosopher-artists theorized difficulty and obscurity as critical ideas and techniques with a political purpose, meant to critique what they saw as the insufficiency of the reasonable, perspicuous discourse of the German Enlightenment.

Though their media were different, the effects of the early Romantics' writings and of Beethoven's early sonatas are strikingly similar; both from the last years of the 1790s, their obscurity and difficulty caused offense among the critical press. In what follows, I first evaluate some of the features of Beethoven's early sonatas which may have provoked such frequently vicious reactions from the press and compare them to those of Haydn; I then discuss how the

\footnotetext{
${ }^{45}$ The Critical Reception of Beethoven by His German Contemporaries, Vol. I, 145.

${ }^{46}$ Barry Cooper, ed., The Beethoven Compendium (New York: Thames and Hudson, 1992), 143. From Emily Anderson, trans., Letters (New York: Saint Martin's Press, 1961), Letter 749.
} 
concepts of obscurity and difficulty were revalued in the writings of Schlegel and Tieck, showing how their transformation quickly surfaced within the critical press in reviews of Beethoven's music; I continue by elaborating the critical intention behind these ideas, tracing their roots to the writings of the Enlightenment critic Johann Georg Hamann (1730-1788); finally, I explore more of Beethoven's early sonatas using the expanded concepts of difficulty and obscurity taken from Hamann, Schlegel and Tieck. By placing several of Beethoven's works squarely within the conceptual space shared with the trio of writers, I suggest that his sonatas participated in the critical phase of early Romanticism.

The artistic world of Beethoven's youth was dominated by a rhetorical aesthetic model. Rhetoric, particularly its element of delivery, maintained a particularly strong association with music in the discourse-obsessed eighteenth century Enlightenment. ${ }^{47}$ Beethoven learned the rhetorical theory of the ancients through his study of the music treatises of Johann Mattheson, Johann Philipp Kirnberger, and Emanuel Bach as well as through direct reading of the Greek and Roman writers. $^{48}$

Within this paradigm, clarity was an important parameter for judging the success of compositions. The aesthetician Johann Georg Sulzer understood clarity to be an alwayscomprehensible presentation which ensured uninhibited communication between composer and listener. In his Allgemeine Theorie der Schöne Künste (General Theory of Beautiful Art), Sulzer compares the "plan" of a composition to the speech of a rhetorician, writing that "[a speaker]

\footnotetext{
${ }^{47}$ My definition of rhetoric comes from the "Rhetoric" entry in the Oxford Companion to Music. In assuming the importance of rhetoric for late eighteenth century music composition and reception, I am joining the company of Tom Beghin and Sander M. Goldberg, who write that "The question for us here is not whether but what a rhetorical sensibility contributes to the understanding of music's conception, performance, and reception in the eighteenth century." See Beghin and Goldberg, eds., Haydn and the Performance of Rhetoric (Chicago: University of Chicago Press, 2007): 5.

${ }^{48}$ George Barth, The Pianist as Orator: Beethoven and the Transformation of Keyboard Style (Ithaca: Cornell University Press, 1992): 6.
} 
will find the most persuasive arguments and ideas for his particular purpose, which is to say, an argument that convinces us completely on account of its great clarity." Sulzer further elaborates that the parts of a composition "must be precisely connected and enchained in larger sections." 49 This makes it clear that compositional clarity, like a coherent spoken argument, must hold between sections so that the connections, where incomprehension is most likely, should be easily understood by the listener.

For reviewers, too, compositional clarity was a criterion on which to judge music. A confounding of clarity resulted in "bizarrerie," a term that often criticized the plan of the composition. Mary Sue Morrow shows this opposition in a review of a set of sonatas by Louis Abeille from 1793. The reviewer writes that the set contains "a certain something that could be called bizarre and that disturbs the clarity," a comment that Morrow takes to be "perhaps a reference to the desirability of a perceptible musical structure." Worded in Sulzerian terms, the bizarre musical structure likely came from the lack of properly "enchained" sections. ${ }^{50}$ The repeated references to the bizarre in reviews of Beethoven's sonatas that we have seen, therefore, most likely refer to confounding transitions between sections, which we will explore later.

Haydn's music was often compared to effective rhetoric; he was admired for the way in which he was able to coherently link together contrasting sections of music. Tom Beghin and Sander M. Goldberg, for example, cite Giuseppe Carpani, who wrote in 1812 that Haydn's music contains "a true arsenal of oratory arms, covering the whole range of what is possible within today's theory of music"; they also quote Stendahl's Life of Haydn from 1818, which compares

\footnotetext{
${ }^{49}$ Nancy Baker and Thomas Christensen, Aesthetics and the Art of Musical Composition in the German Enlightenment: Selected Writings of Johann Georg Sulzer and Heinrich Christoph Koch, (Cambridge University Press, 1995): 69-70. In the General Theory of Beautiful Art, Sulzer also has entries on "klarheit" and "helldunkel." ${ }^{50}$ Mary Sue Morrow, German Music Criticism in the Late Eighteenth Century: Aesthetic Issues in Instrumental Music, (Cambridge University Press, 1997): 68.
} 
musical figures to "the anti-thesis and metonymy in rhetoric." Contemporary comparisons to effective rhetoric are a testament to the way in which Haydn's music clearly develops and connects with itself, much like Sulzer's “argument that convinces us completely on account of its great clarity."

Haydn's keyboard sonatas provide examples of his seemingly effortless ability to subtly bind sections together. One way they achieve this is through well-camouflaged modulations to the dominant, which changes one important musical parameter while maintaining the comprehensibility of others. In the first movement of Hob. 49 in E-flat major, the transition passage from measure 13-24 spins out his modulation from E flat to B flat. The first accidental, a $\mathrm{b}$ natural at measure 17, is the leading tone of the $\mathrm{V} / \mathrm{V} / \mathrm{V}$ of $\mathrm{E}$ flat, a tone far removed from the home key. Despite this, the passage is made entirely comprehensible by its continuity in the motivic and melodic realms; both hands retain the same rhythmic pattern in measure 17 as in the previous four measures, and the melodic line continues upward as it continues its crescendo to the apex at measure 19. The continuity established through these means allows the listener to focus on the motivic and melodic components of the music while also making implicit sense of the changing tonality. ${ }^{52}$

Similarly, in the transition passage, measures 11-17, of the first movement of the Sonata in E-flat major, Hob. 52, Haydn uses the same devices of motivic repetition and melodic direction to enact a modulation to the dominant; here, the melody slowly descends chromatically

\footnotetext{
${ }^{51}$ Haydn and the Performance of Rhetoric, p. 4.

${ }^{52}$ See example 1.
} 
while the left hand repeats its dotted motivic rhythm, until it finds its footing on an $f$ pedal point and completes its modulation to B flat by measure $17 .^{53}$

In the Sonata in C major, Hob. 50, Haydn takes a different route to the dominant, this time making use of the harmonies on strong beats. After alternating between tonic and dominant harmonies each half measure from mm. 8-13, he doubles the harmonic rhythm from mm. 13, beat three, through m. 14, then slows it down to once per measure for mm. 15 and 16. Finally, he doubles the harmonic rhythm once again in measures 17-19, ending on a half cadence on the dominant. The result of these many harmonic rhythm changes is that the dominant harmony gets played on the strong beats for the final three measures, which helps to effect a modulation. Haydn combines this shift with the insertion of important chromatic alterations at measure 16, setting the harmonic ground for the modulation of the next few measures. ${ }^{54}$

The Sonata in B-flat major, Hob. 41, provides examples of Haydn's harmonic surprises. The transition to the dominant follows a straightforward path; at $\mathrm{m}$. 20, after a half cadence that suggests a return to B flat major but leaves open a change of key, Haydn introduces a partially new theme in the dominant. At m. 25, however, he inserts a sudden shift to the parallel minor while also changing the affect through a new theme and texture. All of these changes are unexpected; they are made comprehensible only through the parallel relationship of $\mathrm{f}$ minor to the $f$ major of the previous four measures. A similar surprising change occurs at the beginning of the development, m. 56, at which point Haydn changes key without preparation to the flat six

\footnotetext{
${ }^{53}$ See example 2.

${ }^{54}$ See example 3.
} 
scale degree. The harmonic surprise here is abated, though, by the continuity in theme from the previous measure. $^{55}$

The strong association between Haydn's music and effective rhetoric distanced his music from the emerging early Romantic aesthetic in the first years of the nineteenth century, a detachment which manifests in the writings of music critics at the time. On this topic, James Webster cites the 1801 writings of Johann Carl Friedrich Triest on the similarities and differences between Haydn and the early Romantic writer Jean Paul Richter. For Triest, the important distinction is that Jean Paul's works exhibit a "chaotic design," while for the composer, "transparent representation is not the least of Haydn's virtues." This contrast between writer and composer is telling; here, it is the design of Haydn's works, the Sulzerian comprehensibility of connections between parts of the composition, which separates the older composer from the Romantic writer. ${ }^{56}$

The aesthetic distance between oration and Romanticism would later become marked by a hierarchy; the new Romanticism would decisively trump the older rhetorical ideal. Mark Evan Bonds points this out using the 1810 writings of lawyer and author Ignaz Theodor Ferdinand Arnold, who regards with suspicion Haydn's abilities as a musical orator. Arnold writes that Haydn "knows so cunningly just how to use this [true] statement that he can soon convince us of anything he desires, even if it is the exact opposite of the original statement." Arnold draws a contrast between Haydn and Mozart, the latter whose superior music he believes to represent "an extremely abstract science... a true mathematics of the spirit." ${ }^{, 57}$ Arnold's hierarchy of composers

\footnotetext{
${ }^{55}$ See example 4.

56 James Webster, “Haydn: Style," in Grove Music Online.

57 Mark Evan Bonds, "Rhetoric versus Truth: Listening to Haydn in the Age of Beethoven," in Haydn and the Performance of Rhetoric, ed. Tom Beghin and Sander M. Goldberg (University of Chicago Press, 2007): 114-16.
} 
was completed with the addition of Beethoven by E.T.A. Hoffmann, who placed the younger composer at the top, with Haydn still at the bottom, of the trio of composers in his 1810 review of the fifth symphony.

By 1810 , the incompatibility of the two aesthetics had become clear, and Beethoven's music, the embodiment of new over old, had shed its troubled relationship with the old. The early, impassioned objections of the AmZ reviewers had given way to writings expressing adoration in the style of Hoffmann. Quickly forgotten in the wave of Romanticism that swept German-speaking Europe in the first decade of the nineteenth century and never recovered, the difficult connection between Beethoven's music and the aesthetic world of the Enlightenment remains underexplored. But an awareness of the ways in which Beethoven's piano sonatas fail to adhere to contemporary aesthetic standards opens up a broader understanding of the Early Romantic challenge to the Enlightenment.

Beethoven grew up within the rhetorical aesthetic paradigm with its emphasis on clarity, and he knew its requirements well. He must have understood as well as Haydn that a listener's failure to comprehend music was the fault of the composer, and that communicative clarity, especially when transitioning between "thoughts" or sections of music, was of the utmost importance. ${ }^{58}$ His first set of three sonatas, Op. 2, dedicated to his teacher Haydn, testifies to his efforts to emulate the famously comprehensible works of the older composer. In particular, the transition passages of all three make use of some of Haydn's techniques and are readily comprehensible.

\footnotetext{
${ }^{58}$ Bonds, "Rhetoric versus Truth," 109-128. Bonds talks about the assumptions that changed in listening in the first decade of the nineteenth century, in particular the idea that the responsibility of comprehensibility lay with the composer.
} 
In Op. 2, No. 1, the important modulatory work of the transition passage in the first movement is complete by measure 20 , where Beethoven reaches a dominant pedal of his goal key of A flat. Measures 11-14 do most of the heavy lifting; measure 11 begins on an F second inversion chord, and measure 14 sees the strong arrival, from a dominant seventh chord, of the A flat harmony. In between, Beethoven uses the D flat pitch in the soprano, changing its function to become the important seventh of A flat. This is a very subtle use of this pitch, and he hides it within the familiar turn to further mask the work that it is doing. Throughout, Beethoven uses the triplet turn motive present from the beginning, thus creating a sense of Haydnesque continuity. ${ }^{59}$

In the first movement of Op. 2, No. 2, the transition passage from mm. 32-46 establishes the modulation to the dominant of the dominant, B major. Beethoven maintains the contrapuntal rising triplet-sixteenth and descending eighth motives while adding important accidentals at measure 38 that move the modulation to the B major harmony. At the same time, he writes the 14 measures as one long phrase that climaxes at measure 39 , just after he introduces the accidentals, thereby strengthening the rhetorical bond between key areas. ${ }^{60}$

The first movement of Beethoven's third sonata in the set, Op. 2, No. 3, continues the examples of the other two; the transitional material, from mm. 13-21, repeats itself three times and the third time modulates to the dominant. After it has successfully cadenced on the dominant at $\mathrm{m} .26$, however, Beethoven begins a new theme on the parallel minor; the unprepared tonality combined with new musical material lacks a strong coherence with the preceding section, but

\footnotetext{
${ }^{59}$ See example 5.

${ }^{60}$ See example 6.
} 
rather disrupts the clarity of their relationship. The parallel tonic relationship provides a tenuous thread between sections. ${ }^{61}$

Haydn's sonatas offer some precedent for this moment, as we saw in example 5. However, Beethoven's next set of sonatas, his Op. 10, continues to question the clarity of transitions in ways unforeseeable in Haydn's works. The review of Beethoven's Op. 10 in the AmZ is particularly adamant about the incoherence of the transitional material; the writer notes that the composer's "abundance of ideas...too often still causes him to pile up ideas without restraint and to arrange them by means of a bizarre manner so as to bring about an obscure artificiality or an artificial obscurity...” Indeed, in the Op. 10 sonatas, Beethoven disrupts listeners' expectations about musical connections ever more intrusively. In these sonatas, the composer shows his boldness in defying the aesthetic tradition into which he was born, writing movements that lack even the most basic of transitions between themes or key areas.

The third movement of Op. 10 No. 1 contains a bare structural seam that makes the relationships between sections difficult to understand. At $\mathrm{m}$. 16, the half cadence on $\mathrm{G}$ major that pauses the energetic opening group precedes the more placid E flat major second theme. There is no transition here between key areas, themes or affects. Instead, the opposite occurs; by beginning with a cross-relation, a B flat that clashes with the preceding $\mathrm{G}$ major harmony, the new theme highlights the structural seam, thus pointing to its awkwardness instead of hiding it. ${ }^{62}$

A favorite of Beethoven's, Op. 10 No. 2 contains much that is difficult to understand and to play. ${ }^{63}$ The first movement's transition to the second theme is probably what initially caused

\footnotetext{
${ }^{61}$ See example 7.

62 See example 8.

63 Donald Francis Tovey notes that this was one of Beethoven's favorites in his A Companion to Beethoven's Pianoforte Sonatas (London: Associated Board of the R.A.M. and the R.C.M., 1931).
} 
offense in the press, and is a key to interpreting its other peculiarities. This passage, at mm. 1518 , suddenly changes mood as a way to highlight the upcoming second theme. The rinforzato at m. 15, the sudden forte at m. 16, and the thrice-repeated augmented sixth chord all sound unfriendly after the jolly, slightly wistful piano opening. The pleasant mood returns just as quickly, however; at m. 18, the piano dynamic, rising melodic line and smooth accompaniment of the second theme recall the gentle phrase from $\mathrm{mm}$. 5-8. These few forceful measures seem to poke fun at the structural moment here; they emphasize the absence of what should be a transition to a new theme and a modulation to a new key. ${ }^{64}$

This abrupt shift, placed prominently near the beginning of the sonata, disregards the decorum of Haydn's sonatas. There is no transitional material; after the full stop at m. 18, Beethoven begins a new theme in an unprepared key. Whereas Haydn often carries the listener to a new key using subtle techniques, Beethoven here throws subtlety out the window. The prominent placement, siren-like repetition of the augmented sixth figure, and sudden change of mood of mm. 15-18 counters the polite rhetorical conventions of Haydn's sonatas and instead focuses attention on the fact of this movement's rudeness.

Following this first instance of vulgarity, the music continues to be impolite in different ways. Its accompaniment figures, for example, grow progressively faster and more difficult as the exposition develops, potentially frustrating and offending the sight-reader. After the opening measures contain a simple quarter-note chordal accompaniment, the more difficult sixteenth-note accompaniment pattern at measure 18 gives way to an even faster triplet pattern at $\mathrm{m}$. 30; at mm. 55-64, the seemingly random fluctuation between triplet and the fastest quadruplet accompaniment patterns might confound an unprepared sight-reader.

\footnotetext{
${ }^{64}$ See example 9.
} 
Other features of its keyboard technique make this movement particularly frustrating to execute. At mm. 46-50, for example, the harmonic simplicity belies the complicated patterning of both hands. Each of these four measures subtly changes the pattern; the not quite exact repetition makes it more difficult than if it had been completely different. In addition, the jumping two-note chords in the right hand undermine any attempt to arrive at an easy fingering. Instead, the passage requires the hand to jump several times to awkward positions.

Beethoven also plays with phrasing patterns, either exaggerating or disrupting the shape of the melodic line through dynamic markings. He overstates the natural phrasing pattern at $\mathrm{m}$. 21 and again at $\mathrm{m} .25$, where the peak of the phrase receives a s $f$ in an exaggeration of the shape of the phrase. Inversely, at m. 31, the sf on the c" places weight on the pick-up to the short sixteenth-note gesture, a half beat before the more natural emphasis at the downbeat of the descending gesture. He repeats this off-balance phrasing five times. A few measures later, he exaggerates the natural phrasing of a similar gesture in the left hand, beginning at the last half beat of $\mathrm{m} .41$ and going to $\mathrm{m} .44$.

Frequent attempts to arrive at a goal, followed by their failure, undergirds much of this exposition. At m. 29, for example, the third repetition of the phrases with the exaggerated shapes seems as if it drives toward a peak. Here, there is an expectation of movement; it is modulating, it receives a ff dynamic, and it continues the upward motion of the melodic line of the phrase. Instead of culminating in a cadence, however, it backs away at $\mathrm{m}$. 30. This failure to culminate immediately recurs between $\mathrm{mm} .30$ and 35 , with an intensification of rhythm and register yielding only a weak melodic line at $\mathrm{mm}$. 36-37. 
These obscurities and difficulties have been noticed and addressed before. William Kinderman, for example, offers analyses of several pieces that exhibit these traits, showing how Beethoven in Op. 10 No. 2 "revel[s]...in the unexpected, the incongruous, and the grotesque," or alternatively, how in Op. 10 No. 3 he searches for "music that seeks and discovers its own basic material.",65

Kinderman's analyses, while insightful, contextualize Beethoven's music within the tradition of the polite, Enlightened discourse exemplified by the witty music of Haydn and the refined, satirical novels of Sterne. As we have seen, however, Beethoven's music was not received as if it were a model of mannered humor; instead, it offended the sensibilities of the critics. By ignoring the contemporary critical reception that was so insulted by these works, Kinderman passes over an important part of the meaning of these sonatas.

Friedrich Schlegel addresses the issue of obscurity in art in his essay "On Incomprehensibility" from 1800. Written in response to criticisms that Schlegel's journal, the Athenaeum, was obscure and difficult to understand, the essay argues for the importance of difficulty in art. ${ }^{66}$ Schlegel's argument contains three major threads: the first point is that the journal is meant to function as a forum which explores the very possibility of clear communication using language, a project that he continues within the essay; the second claim is that easily comprehensible, reasonable discourse is not only unattainable, but is also undesirable, for there is an aspect of the human spirit that resists perfect comprehensibility and whose value lies in mystery; and his third contention holds that difficulty in art serves as a catalyst for artistic, and ultimately social, progress.

\footnotetext{
${ }^{65}$ William Kinderman, "Beethoven's High Comic Style in Piano Sonatas of the 1790s, or Beethoven, Uncle Toby, and the "Muckcart-driver," Beethoven Forum 5 (1996): 130, 133.

${ }^{66}$ J.M. Bernstein, ed. Classic and Romantic German Aesthetics (Cambridge University Press, 2003): 297-307.
} 
Within the essay, the strains of argument unfold dynamically, for Schlegel attempts to make his points by demonstrating, in addition to stating, the fallacies of reasonable discourse. He does make the first point explicitly, writing that:

Of all things that have to do with communicating ideas, what could be more fascinating than the question of whether such communication is actually possible? And where could one find a better opportunity for carrying out a variety of experiments to test this possibility or impossibility than in either writing a journal like the Athenaeum oneself or else taking part in it as a reader? ${ }^{67}$

Schlegel continues by testing the possibility of communication within the essay. He writes obscurely, managing to leave open contradictory possibilities for interpretation, while also using lines of reasoning that ultimately go nowhere. For example, his introductory argument, consisting of the first six paragraphs of the essay, begins sincerely as Schlegel attempts to arrive at a universal language that is understandable by everybody. As the line of argumentation proceeds, however, the line between sincerity and irony becomes fuzzy. When his focus turns to Girtanner, an eighteenth-century physician who predicted that man would make gold by the nineteenth century, the tone has clearly become ridiculous. Ultimately, although he begins by stating his sincere hope in finding a common, universal language for the clarity of understanding, Schlegel only manages to conclude at the end of this section that Girtanner, being dead, can no longer hope to make gold; at most "one might extract with all possible artistry only so much iron out of him as might be necessary to immortalize his memory by way of a little medallion." ${ }^{\text {,68 }}$

Following this detour, Schlegel once again returns to sincerity, beginning a new section of the essay by attempting to show the reader his intention behind his famous fragment about the

\footnotetext{
${ }^{67}$ Ibid, 297.
}

${ }^{68} \mathrm{Ibid}, 300$. 
three tendencies. ${ }^{69}$ His main undertaking here is to define and to demonstrate irony, which he states he was using when he wrote the fragment. While this section begins in earnest, it too blurs the line between sincerity and irony as it progresses. Schlegel finds himself more and more lost in irony as he attempts to define its various flavors, from coarse, fine, and extra-fine, to dramatic irony, double irony, "when two lines of irony run parallel side-by-side without disturbing each other”, and finally, irony of irony, “if one can't disentangle oneself from irony anymore, as seems to be happening in this essay on incomprehensibility.",70

After these two attempts at comprehensibility, both of which culminate in a nearly nonsensical, ridiculous claim, Schlegel concedes that he has been unable to make himself understandable. This is where the essay takes an unexpected argumentative turn; rather than admit defeat to the Enlightenment value of intelligibility, Schlegel decides to argue instead for the positive value of incomprehensibility, writing, "[b]ut is incomprehensibility really something so unmitigatedly contemptible and evil? Methinks the salvation of families and nations rests upon it." He argues that both state systems and the happiness of man are, at their core, unsupportable by bare reason; they "would crumble the moment one subjected [them] to rational analysis." Instead, there always will be mysteries of understanding that are essential for the maintenance of social structure and individual coherence.

Schlegel further justifies his support for the positive value of incomprehensibility by arguing that it will help readers to strive for understanding, which will ultimately make them better people:

\footnotetext{
${ }^{69}$ In no. 216 of his Athenaeum Fragments, Schlegel wrote about "The French Revolution, Fichte's philosophy, and Goethe's Meister [as] the greatest tendencies of the age." Classic and Romantic German Aesthetics, 251.

${ }^{70}$ Classic and Romantic German Aesthetics, 305.
} 
Another consolation for the acknowledged incomprehensibility of the Athenaeum lies in the very fact of this acknowledgement, because precisely this has taught us that the evil was a passing one...Then the nineteenth century will indeed make a beginning of it and then the little riddle of the incomprehensibility of the Athenaeum will also be solved...Much hidden incomprehension will still erupt. But understanding too will reveal its omnipotence: understanding that ennobles disposition into character, elevates talent into genius, purifies one's feelings and artistic perceptions. Understanding itself will be understood, and people will at last see and admit that everyone can achieve the highest degree and that up to now humanity has been neither malicious nor stupid but simply clumsy and new.

Notwithstanding the possible irony in this passage, this is the culmination of Schlegel's argument in this essay; after two failed attempts at clear communication, he scraps his search for clarity and instead gives a defense of obscurity. As a way of understanding the obscurities of Beethoven's sonatas and their reception, this last is a most important point. By redefining artistic incomprehensibility as a means to achieve individual and social progress through the struggle to understand, Schlegel revalues a concept that the Enlightenment had denigrated.

Schlegel's revaluing of artistic obscurity in 1800 foretells a reversal of critical attitudes within the $A m Z$ soon after. While the first reviews of Beethoven's music, in 1798 and 1799, contained objections to the difficulty of understanding and performing it, this view changed suddenly over the next few years. The review of his Op. 26 and 27 piano sonatas in the AmZ from 1802 shows this transformed attitude toward Beethoven's music. The reviewer writes about the three as a group, remarking that:

Here, everything difficult and artistic is part of the expression and therefore the essential point. Whoever complains here....about the difficulty of the ideas or the execution is like those popular philosophers who insist on presenting any profound treatise in the language of polite conversation at tea. ${ }^{71}$

\footnotetext{
${ }^{71}$ As told by Robin Wallace, this shows a new attitude toward his music. Wallace speculates that this attitude may have come as a result of a veiled threat written by Beethoven in a letter to the publisher of the AmZ, Gottfried Christoph Härtel. In Beethoven's Critics, pp. 9-10.
} 
The reviewer's insistence on the value of difficulty lies in stark contrast to those reviews of just a few years before, in which the reviewers expressed exasperation and outrage against Beethoven's difficulties; it also reflects Schlegel's philosophical position on the importance of incomprehension for artistic and social progress. Difficulty, which had been simply an impediment to communication, now has a conceptual foundation which gives to it a new, meaningful potential. It is because of this change in attitude that the reviewer above can claim that the difficulty itself is "part of the expression," rather than simply an impediment to communication.

But there is more to the new aesthetic attitude in this pair of writings. The comment criticizing "the language of polite conversation" in the review is pointed, reflecting a negative revaluation of politeness. The earlier reviews had caused outrage precisely because Beethoven's Op. 10 sonatas exuded rudeness through their incomprehension; now, the value that comes from difficulty in understanding brings with it a corollary devaluing of politeness.

Schlegel's discussion of Girtanner from his essay above is another example of impolite discourse, a theme that returns often in his essay. Schlegel's rudeness is evident on a large scale in the very fact that he wrote an article defending his journal against accusations of incomprehensibility. It also surfaces repeatedly in his use of language; his metaphors are often inappropriately specific, his ironies sometimes lapse into sarcasm or mockery, and his juxtapositions of mystical and rational language confuses their assumed separation.

Ludwig Tieck's play Puss-in-Boots (Der Gestiefelte Kater) from 1797 expresses the difficulty and rudeness of this new aesthetic; furthermore, it enacts these values in ways that are similar to Beethoven's Op. 10 sonatas. Tieck writes a play-within-a-play, in which the 
"audience" represents a concert-going public whose job it is to determine if the author has created a work of good taste. ${ }^{72}$ The "play" itself contains only the skeleton of a plot, which is proclaimed in a monologue at the beginning of the first act. In a sentence, three brothers, whose father has died, all receive an inheritance; the youngest receives the family cat, who later surprises the brother by his ability to talk and promises him a fortune. After this monologue, the audience members immediately interrupt and declare that the story has been displayed too baldly. Instead of such a rude and artless exposition, they believe that the author should "slip the story cunningly under the spectator's feet, not throw it right in his teeth." ${ }^{, 73}$ As the play progresses, however, the situation only becomes more ludicrous, and the first act ends with a scene of almost all new characters who have little relation to the previous scenes. By this point, the cat has disappeared, and the original plot no longer seems relevant. After the first act ends, half of the "audience" confesses that the story makes no sense, while the other half has enjoyed the new characters.

The two most relevant aspects of Tieck's work for our purposes are its incomprehensibility and its critique of good taste, or politeness. On the former, the obscurity of the play is conveyed through incongruities and disruptions of all kinds, thus destroying assumed conventions in ever-broader terms. As the play continues past the first act, for example, "audience" members begin to interrupt more frequently; the "author" comes on stage again and again to appease the audience; some of the actors in the play-within-the-play break character, extemporize that the play is going too long, and even change out of their costumes; eventually, the set is torn down as the "audience" watches, and they throw rotten vegetables at the author.

\footnotetext{
${ }^{72}$ In the prologue, the "audience" repeatedly stresses, to the point of absurdity, that good taste is necessary for a successful play.

${ }^{73}$ Ludwig Tieck, Der gestiefelte Kater, ed. and trans. Gerald Gillespie (Austin: University of Texas Press, 1974), 45.
} 
The "audience" has decided that the "play" lacks coherence in any way, but the dissolution of the usual boundaries of the genre also leaves the reader disoriented. This incomprehensibility is an affront to the good taste of the reader, just as it undermines the polite sensibilities of the "audience." By breaking conventions that expose the workings of the play as a play, Tieck purposefully commits the same act of rudeness as Beethoven, whose Op. 10 sonatas similarly lay bare the mechanisms of music.

The rudeness and obscurity of these works, while interesting simply for the radical change in aesthetic that they represent, actually have a broader, critical, intention. More than a simple shift in aesthetic trends, the turn to obscurity and rudeness of Schlegel's writings, Tieck's plays, and Beethoven's sonatas offer up a pointed critique of central elements of Enlightenment discourse, including the Enlighteners' faith in reason and their uncritical acceptance of the transparency of language. Schlegel's likening of "philosophical words" to a "secret brotherhood" that "exert[s] the invisible power of the world spirit" hearkens to an idea of philosophy as its own religion, and his explicit questioning of the possibility of communication through language shows his interest in how ideas are constructed through language. ${ }^{74}$

The critique of limpid Enlightenment reason can be traced back to the works of the writer and critic Johann Georg Hamann (1730-1788), whose influence in the writings of Schlegel and Tieck continues to be little recognized. ${ }^{75}$ Hamann, greatly admired by such members of the early Romantic generation as Jean Paul Richter, F.W.J. Schelling, and Friedrich Schlegel himself, was

\footnotetext{
${ }^{74}$ Friedrich Schlegel, "On Incomprehensibility," in Classic and Romantic German Aesthetics, ed. J.M. Bernstein (Cambridge: Cambridge University Press, 2003), 298.

${ }^{75}$ Today Hamann remains a relatively unknown figure, although there has been a recent resurgence of Hamann scholarship. See John Betz, After Enlightenment: The Post-Secular Vision of J.G. Hamann (Malden, MA: WileyBlackwell Pub., 2009); also Robert Alan Sparling, Johann Georg Hamann and the Enlightenment Project (Toronto: University of Toronto Press, 2011). For a somewhat older but excellent contextualization of Hamann, see the discussion on the German Sturm und Drang in Frederick Beiser, The Fate of Reason: German Philosophy from Kant to Fichte (Cambridge: Harvard University Press, 1987).
} 
the first to enact a pointed critique of what he saw as the Enlightenment's faith in the absolute authority of reason. In addition to his admiration by the Early Romantics, Hamann was a friend of Kant and was highly esteemed by major figures of the late eighteenth and nineteenth centuries, including Goethe, Herder, Hegel, and Kierkegaard. ${ }^{76}$

Forty years before the generation of the early Romantics, Hamann wrote critiques of the Enlightenment that revolved around what he saw as the misuse of reason by the Enlighteners. For Hamann, the Enlightenment focus on clarity and the transparency of language is often no more than a seduction, a way to subtly convince the observer of a seemingly transparent, logical progression of ideas; instead, Hamann employs a deliberate obscurity in his language as a critique of the Enlightened style of discourse. Kenneth Haynes describes Hamann's use of language, commenting that:

The style he cultivated was the opposite of that of the Encyclopédie, obscure rather than perspicuous, personal and even private rather than disembodied and anonymous, erudite and sometimes obscene rather than polite and complaisant. The style was a reproach to the language used by Enlightenment writers; it was a critique of their language by means of his language. ${ }^{77}$

Through its obscurity, Hamann's style compels the reader to pay attention to his use of language as language. Haynes further remarks that:

Hamann cultivates a deliberate impurity. If philosophy desires to become independent of history and tradition, he writes with continual references to historical tradition; if it is concerned with truths that are independent of experience, he inserts the body and all its functions; if philosophy is to be reasonable, abstract, and transparent, his style will be

\footnotetext{
${ }^{76}$ Betz, After Enlightenment: The Post-Secular Vision of J.G. Hamann, 2. Goethe called Hamann "the brightest mind of his day." Hegel noted Hamann's "penetrating genius." Kierkegaard assessed him, along with Socrates, as "perhaps the most brilliant minds of all time."

77 Johann Georg Hamann, Writings on Philosophy and Language, ed. Kenneth Haynes (Cambridge: Cambridge University Press, 2007), viii.
} 
obscure, weighted with concrete details, strange; in his prose the fact of language, especially in its non-representational aspects, is centrally obtruded. ${ }^{78}$

The style of Hamann's writing, therefore, is central to his critique. Rather than employ lines of abstract, disembodied reasoning to argue against the authority of reason, Hamann intentionally writes obscurely and disjointedly. He inserts metaphors and allusions, quotes sacred scripture, and writes typologically; that is, his historical figures are often symbols that stand in for his contemporaries. An understanding of his texts requires considerable effort and extensive exegesis, and this is part of the point of his writing; for Hamann, the light of understanding only comes out of the darkness of incomprehension, an idea that will be taken up by Friedrich Schlegel and the Romantics.

Hamann uses obscurity as a way to emphasize the artificiality, the tangibility, and the constructed nature of language, another idea later developed by the early Romantics. By welding language to thought through his writing style, Hamann emphasizes that an independent faculty of reason, as distinct from its use within language, is nothing more than an imagined fabrication of the philosophes. As Gwen Griffith-Dickson elaborates:

Language is the embodiment of experience and tradition; as long as the ability to think rests on language, neither 'reason' nor 'philosophy' can be pure of the empirical, of experience, and of the experience of the others to whom we relate. It itself, for Hamann, embodies a relation: it itself is a 'union of opposites', of the aesthetic and the logical, the bodily and the intellectual; it unites the divisions Kant's Critique creates. For Hamann, in contrast to Kant, the question is therefore not so much 'what is reason?' as 'what is language?', as he writes in a letter. This is the ground of the paralogisms and antinomies that Kant raises in his Critique. Sharing Hume's empiricism and Berkeley's suspicion of universals and abstract terms, he concludes: "Hence it happens that one takes words for concepts, and concepts for the things themselves" (ZH 5, 264:34-265:1).

\footnotetext{
${ }^{78}$ ibid, xi.

${ }^{79}$ Gwen Griffith-Dickson, "Johann Georg Hamann", The Stanford Encyclopedia of Philosophy (Summer 2013 Edition), Edward N. Zalta (ed.), URL = <http://plato.stanford.edu/archives/sum2013/entries/hamann/>. The reference within the quotation refers to: Hamann, Johann Georg. Briefwechsel, edited by Walther Ziesemer and Arthur Henkel (from volume 4 on, edited by Henkel alone). 8 volumes. (Wiesbaden/ Frankfurt: Insel Verlag, 19551975).
} 
Hamann's writing, as a critique of Enlightenment reason, constitutes an aesthetic in itself. In addition to obscurity, disjointedness, and an intentionally delayed process of comprehension, it also includes sudden, clear, lightning-flashes of understanding through pithy phrases, as well as ironic sublimities, "his tendency precisely at the most sublime moments of his texts to indulge in the comical, the trivial, the fatuous, or even the obscene, thereby effecting an intentional 'break of style' or Stilbruch. ${ }^{, 80}$ Later, Friedrich Schlegel would similarly "delight in insoluble mixtures of anything antithetical: nature and art, poetry and prose, gravity and jest, one of the highest taboos of Enlightenment aesthetics." ${ }^{81}$ In "On Incomprehensibility," Schlegel performs a Hamannian "break of style" when his arguments build themselves up in seeming seriousness only to twice culminate in what is effectively nonsense. Tieck's "Puss-in-Boots" extends the spirit of the critique; the plot, characters, and set gradually unravel, as does the comprehension of the "audience" and the reader, thereby forcing us to notice the processes by which a "play" is constructed.

Following Hamann, Tieck, and Schlegel, Beethoven participates in the culture of their critique of Enlightenment reason through his Op. 10 sonatas. While the fact of their obscurity offends Enlightened ears, the method of their obscurity underscores the means by which music is constructed, emphasizes its processes, and forefronts its absurd elements. These sonatas, whose rudely incomprehensible passages compel a confrontation with music as music and whose difficulties ultimately yield understanding, are more understandable through the lens of Schlegel's argument, Tieck's play, and Hamann's stylistic critique of abstract reason.

\footnotetext{
${ }^{80}$ Betz, 11.

${ }^{81}$ Senner, et al. The Critical Reception of Beethoven by His German Contemporaries, 17.
} 
As yet another set of sonatas which offended reviewers, Beethoven's Op. 31 from 1802-3 continues to point out its own musical means and ways by "throw[ing] it right in the teeth" instead of "slip[ping] the story cunningly under the spectator's feet," as Tieck's audience member says. In the first movement of Op. 31 No. 1, Beethoven makes much of the modulation to the dominant. Measures 30-45 overwhelm the listener with a forte section of running octave sixteenth notes, whose direction points rather bluntly toward a modulation to the dominant. Measures 39-45 conclude the section with a bombastic, six-measure long d major arpeggio whose ultimate rinforzandoed, fermataed half cadence is absurdly inevitable. Afterward, Beethoven immediately dissipates the bombast with a return to the piano opening theme and the original key; the move to the dominant, so loudly proclaimed, never happens.

After building up this powerful expectation of a modulation to the dominant, the actual modulation, at measures 53-64, is to the remote key of B major; furthermore, it is surprisingly abrupt. Enacted through a third-relation on a forte chord, the transition consists of several repetitions of this third relation, a strategy that emphasizes the means by which Beethoven is modulating. The second theme comes rapidly afterward, with the only means of preparation through a trilled sixteenth-note passage. ${ }^{82}$

The piano sonata Op. 31, No. 3 presents a case of difficulty in comprehension followed by resolution. Like Op. 10, No. 2, the difficulty presents itself as a harmonic riddle; unlike Op. 10 , No. 2, the later sonata gives the riddle in the first notes, thereby leaving the listener without any context with which to work. Here, the question lies in the key of the piece, which remains a mystery until the eighth measure. Before this downbeat, the music seems to be playing a game of

\footnotetext{
${ }^{82}$ See example 10.
} 
slow harmonic enlightenment, revealing its harmonic secrets over several measures while often pausing for reflection.

The sonata opens with a first-inversion minor seventh chord, along with a short dotted rhythm figure, that is repeated in the second measure. The figure changes in the third measure, but the harmony remains the same. The fourth and fifth measures provide little clarification. Though the harmony changes in these two measures, the fully diminished chords could point to several different possible keys. By the end of the fifth measure, the only hint of direction comes in the rising melody from $\mathrm{f}^{f}$ to $\mathrm{f} \#$ in the treble and from $\mathrm{AA} b$ to AA in the bass. Without harmonic help, however, this hint is not enough to understand a key. The downbeat of measure six is a revelation; the second inversion major chord sounds like it could be a V six-four. Punctuated by a sforzando and a fermata, this moment is given special prominence, and rightly so, for it is the first harmony that gives a semblance of a key. Even here, though, the information remains scarce. Lingering on a second-inversion major chord, the only directional harmony in the first six measures, keeps the listener in the dark for a while longer. When tempo resumes at measure seven, we hear the same harmony, quickly moving to the first tonic harmony at measure eight. ${ }^{83}$

The mysterious key at the beginning of Op. 31 , No. 3 has been remarked upon before. It is a prominent feature of the sonata, partly because it begins the work, but also because of its unique nature. To begin a piece of music without revealing its key withholds one of the most important items that orients the listener. Without the key, understanding is impossible. It is an aspect of music that goes without saying, that is taken for granted, and that seems to come naturally. To withhold it is to point to it, and to point to a fundamental assumption is to take

\footnotetext{
${ }^{83}$ See example 11.
} 
away its power. In this way, this move of Beethoven's performs the same function as Tieck's removal of the fourth wall in Der gestiefelte Kater. Just as Tieck deconstructs the very idea of a play by pointing to its artifices, Beethoven reveals the artifice of the key in music.

Beethoven's image even today tends to transcend history. His position as a borderline Classical and Romantic composer is based on these categories which are not historically situated. The Grove Music Online characterizes Beethoven's influence thus:

Even nowadays, in the lapidary invocation of 'the three Bs', Beethoven is popularly imagined as rising above the historical terrain of Western music, linking Bach to Brahms.

The sheer drama and scope of Beethoven's most ambitious works fostered an overriding perception that his music coheres organically even to the point of inevitability. Beethoven's art registered as a sublime force of nature: here was a music that fully embodied the recently propounded shift in aesthetics from mimetic imitation of the products of nature to expressive emulation of her processes. The overmastering coherence felt in Beethoven's music became an imposing measure of the greatness of musical artworks. Not only individual works but whole genres in his output came to assume a wholeness and totality, as well as a sense of teleology: the symphonies, the string quartets and the piano sonatas are all treated as coherent narratives of creative development.

Beethoven's obscurity and difficulty cannot be contained within such ideas:

"overmastering coherence," "wholeness and totality," and "teleology" only accurately describe a part of Beethoven's oeuvre. What began in his sonatas, through their disruptions and incoherences, as a critique of rhetorical musical processes ultimately embodied exactly that same requirement of "coherence," only through the theory and lens of the later Romantics.

Modern scholarship ignores the early, negative reviews, and the related strong association of Beethoven's early sonatas with the Enlightenment critique of the early Romantics. Instead, there has been a contradiction between the current categorization of early Beethoven as a Classical composer who extends a tradition, and his reception as a stylistic rebel. 
John Daverio has written about the discrepancy between the emerging world of early Romantic aesthetics in which Beethoven wrote his first sonatas, and the older model of aesthetics which is typically used to describe his music. He remarks on this incongruity in Dahlhaus's monograph on the composer, writing that "Dahlhaus strives to frame his discussion of Beethoven's music within the classicizing aesthetics of the eighteenth century," while also noting Dahlhaus's 'dual tendency to distance Beethoven from the 'new,' 'esoteric' aesthetics of the early nineteenth century while at the same time drawing on its critical precepts. ${ }^{84,}$

The distancing of Beethoven from his own time has produced a much-discussed historical gap in Romantic repertoire, in which writings about music by early Romantics such as Tieck and Wackenroder supposedly precede the music that, written over a decade later, would be able to appropriately express them. ${ }^{85}$ This problem has been described by Mark Evan Bonds, who observes that this gap "has led several generations of twentieth-century scholars to stake out the remark-able ( $\mathrm{sic}$ ) position that the visionary outpourings of the late 1790s anticipated a body of music yet to be composed." 86

Yet, these discussions usually rest on a mystical understanding of Romanticism that derives from the “endless longing” of E.T.A. Hoffmann's famous 1810 review of Beethoven's fifth symphony. While Hoffmann developed his version of Romanticism out of earlier writings of Tieck and Wackenroder, it leaves out certain important characteristics of the earliest enunciations of the aesthetic. As it was first practiced by writers such as Tieck, Jean Paul

\footnotetext{
${ }^{84}$ John Daverio, "Dahlhaus's Beethoven and the Esoteric Aesthetics of the Early Nineteenth Century," Beethoven Forum 2/1(1993): 190.

${ }^{85}$ Bonds notes that this gap was created by "several generations of twentieth century scholars [who] stake out the remarkable position that the visionary outpourings of the late 1790 s anticipated a body of music yet to be composed," and that "Dahlhaus argued that the Romantic aesthetic preceded Romantic music."

${ }^{86}$ Mark Evan Bonds, "Idealism and the Aesthetics of Instrumental Music at the Turn of the Nineteenth Century," Journal of the American Musicological Society 50/2-3 (Summer-Fall, 1997): 388.
} 
Richter, and Friedrich Schlegel, Romanticism included a strongly critical component in addition to its Hoffmannian mysticism. When early Romanticism is understood to incorporate a criticism of Enlightenment reason, the "artificial obscurity" of Beethoven's early sonatas, as well as their vehemently critical reviews, make more sense in their time and help to fill the "gap" between repertoire and aesthetics from these years. 
Example 1: Haydn Keyboard Sonata Hob. 49

68

SONATE in Es

Für Maria Anna Edle v. Gennzinger

1. Juni 1790 Hoboken XVI:49
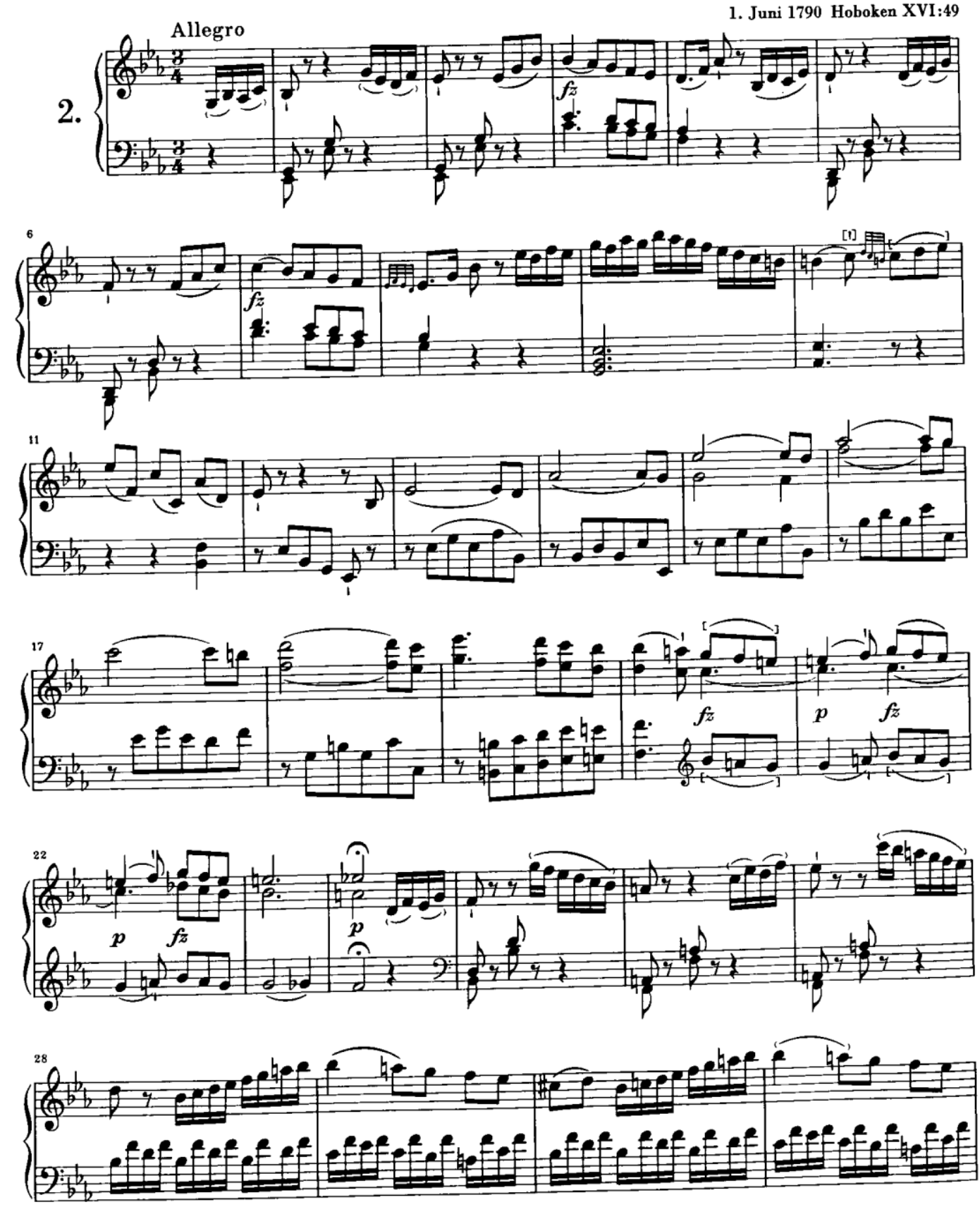
Example 2: Haydn Sonata in E-Flat Major, Hob. 52

84

DREI ENGLISCHE SONATEN
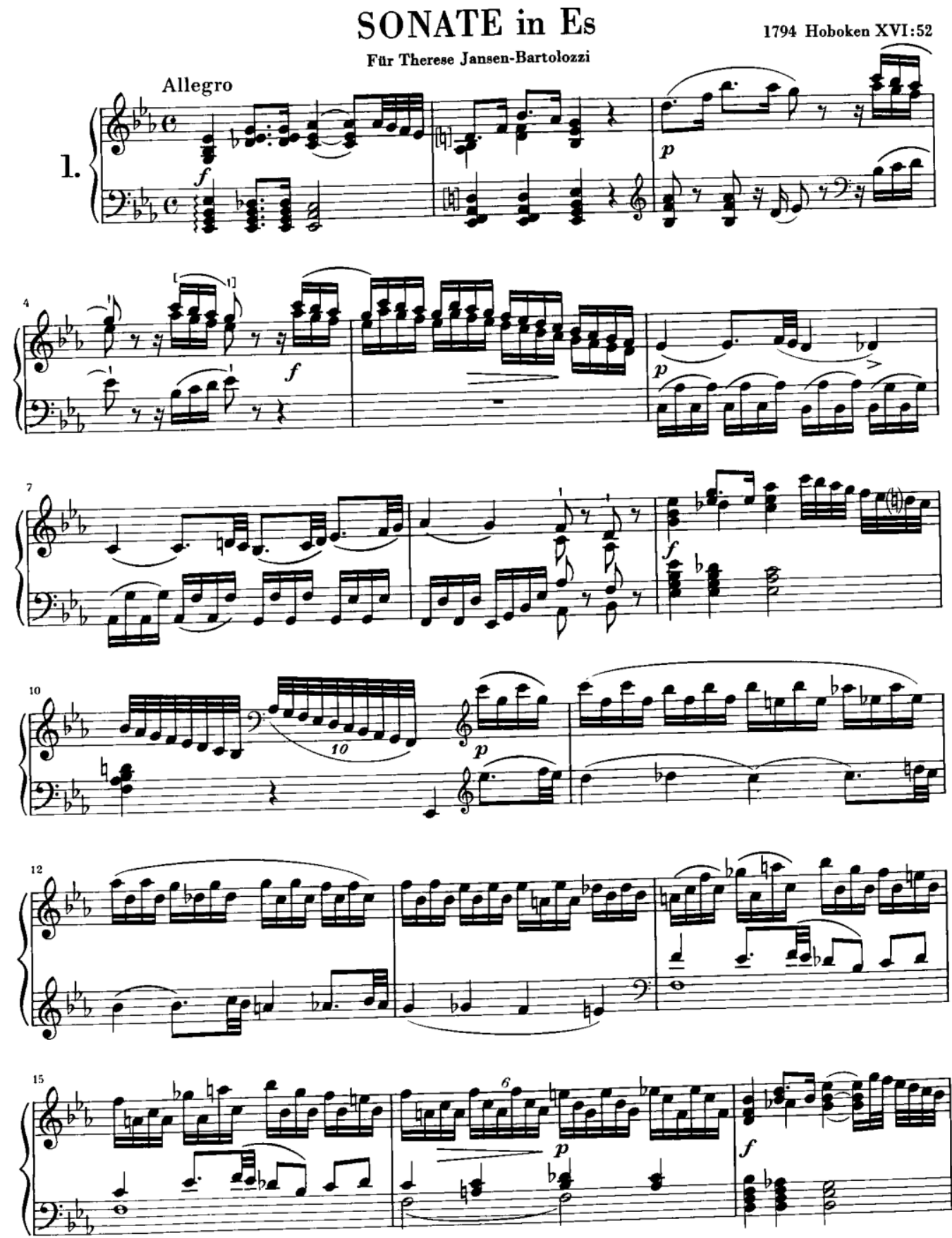
Example 3: Haydn Keyboard Sonata in C Major, Hob. 50

100

SONATE in C

Für Therese Jansen-Bartolozzi
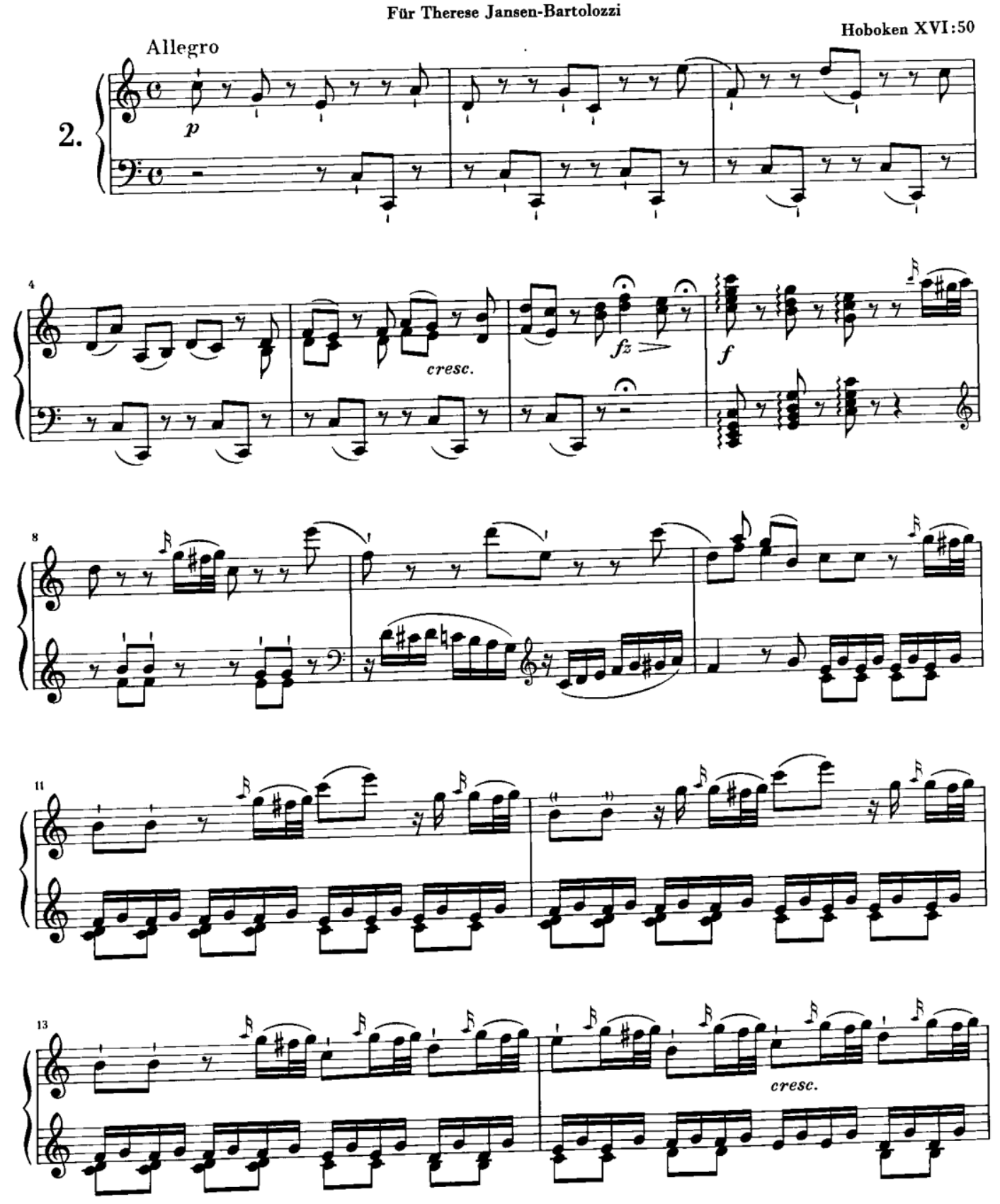
Example 4:Haydn Keyboard Sonata in B-Flat Major, Hob. 41

40

SONATE in B
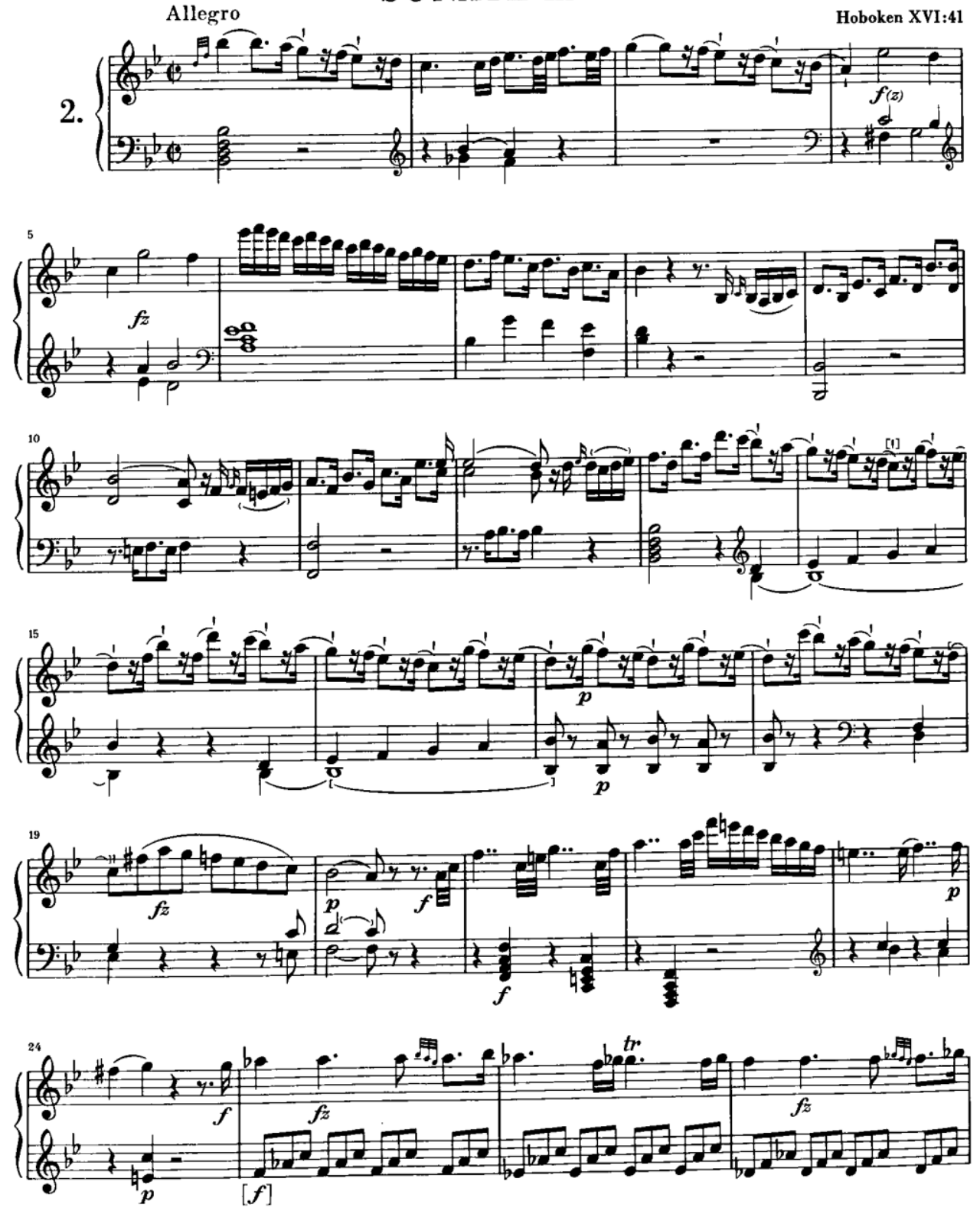

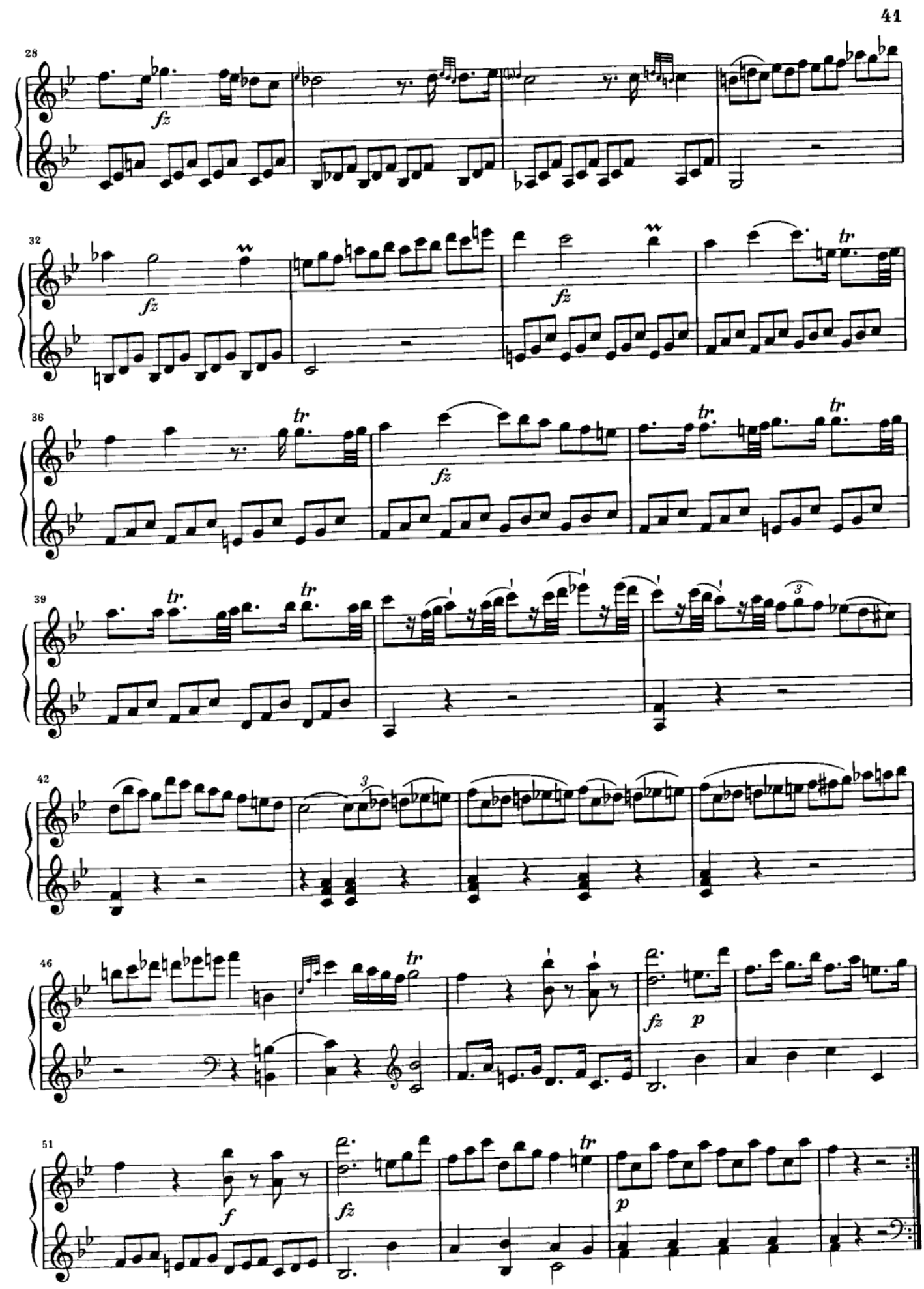

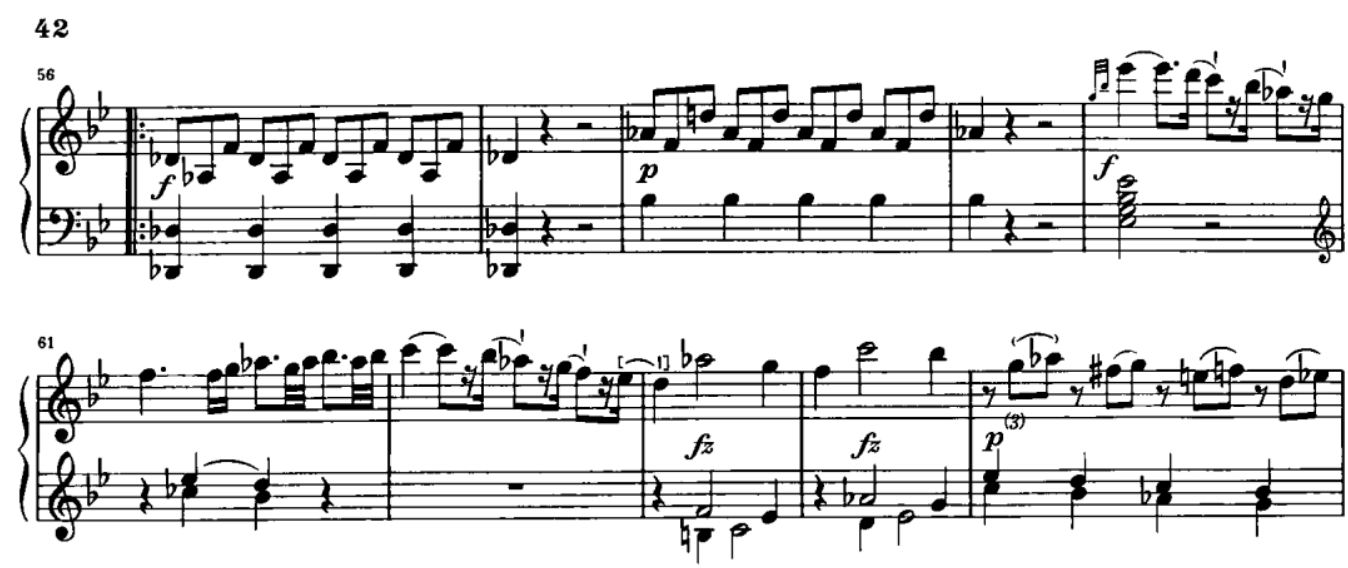

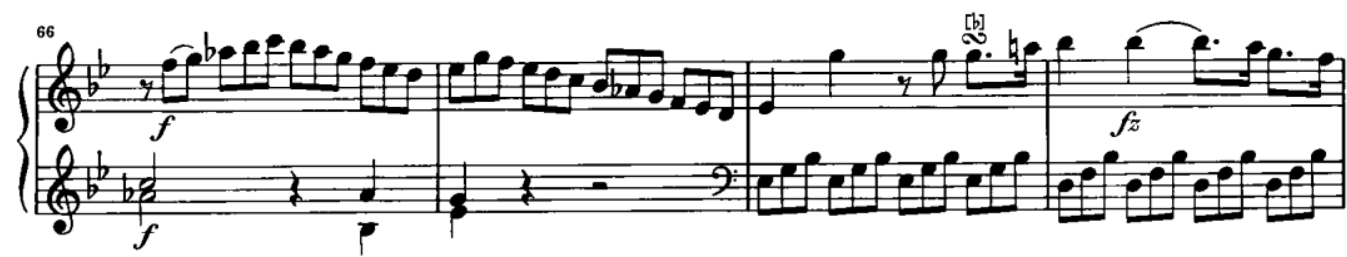

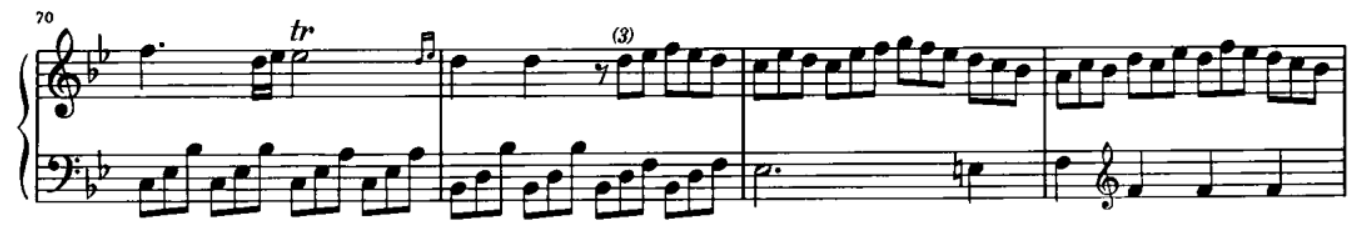

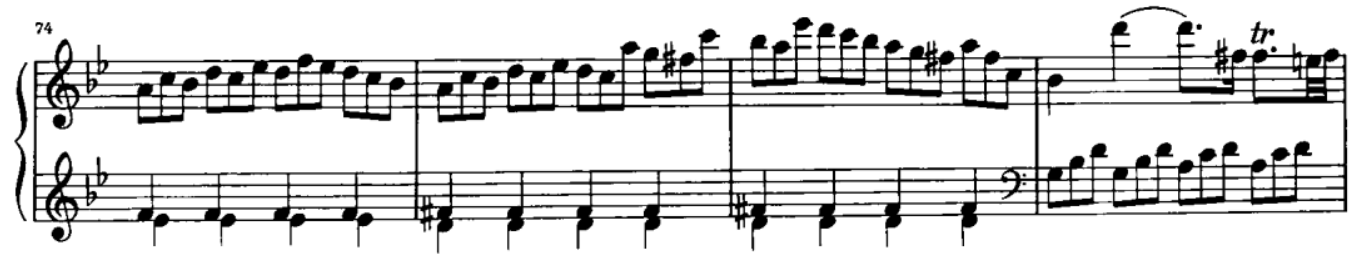

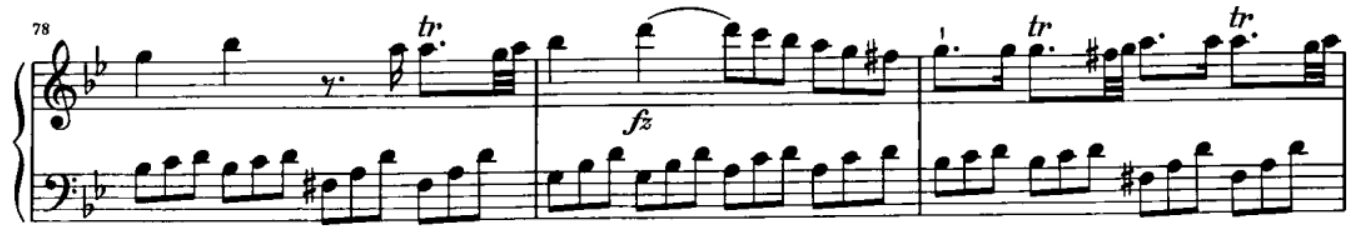

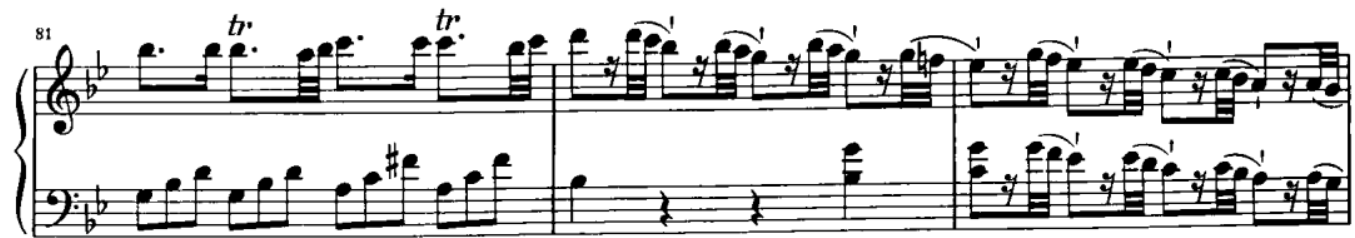


Example 5: Beethoven Piano Sonata, Op. 2 No. 1

2

\section{SONATE}

f-moll

Joseph Haydn gewidmet
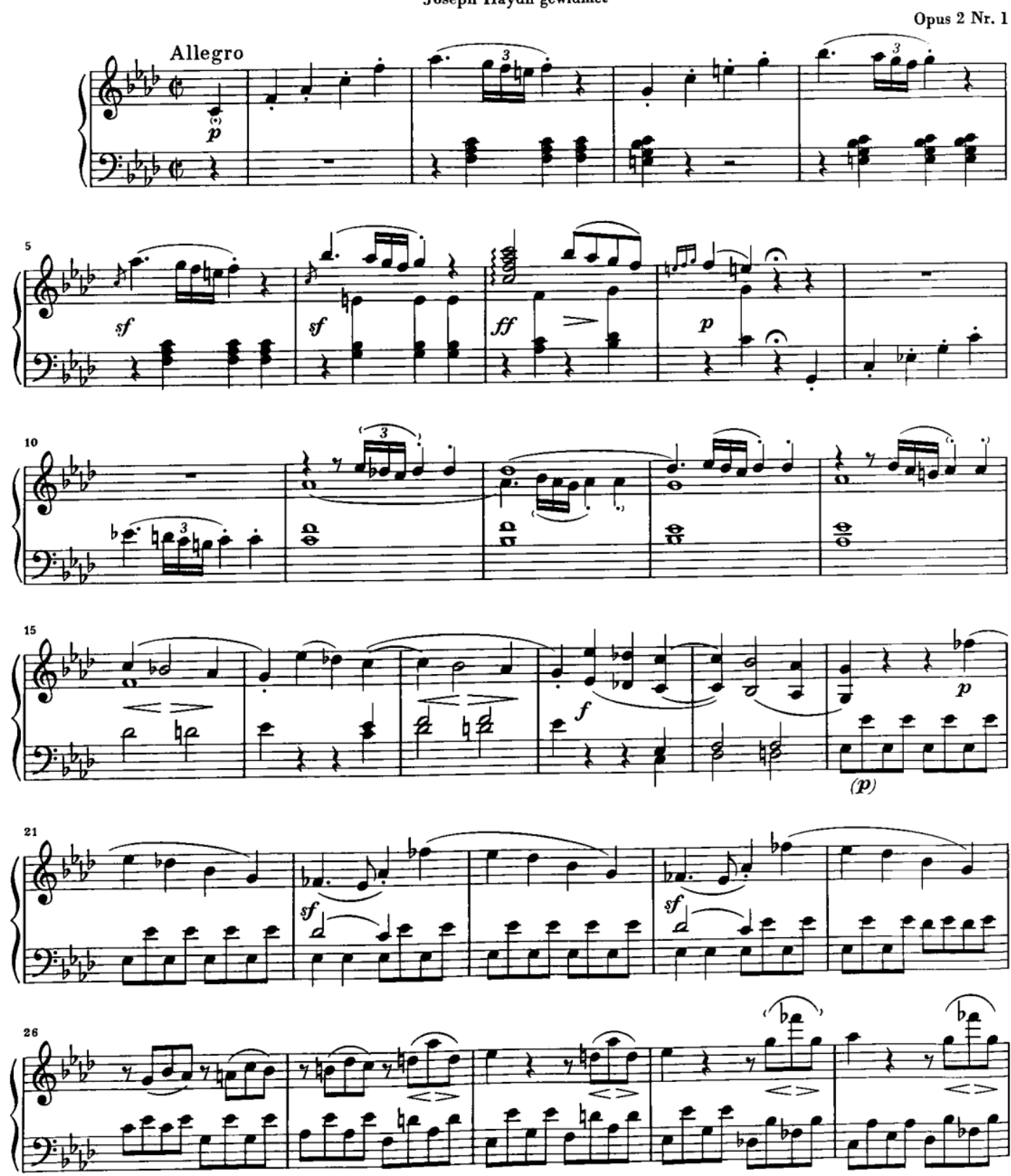

(C) 1971 by G. Henle Verlag, Manchen-Duisbarg 
Example 6: Beethoven Piano Sonata Op. 2, No. 2

18

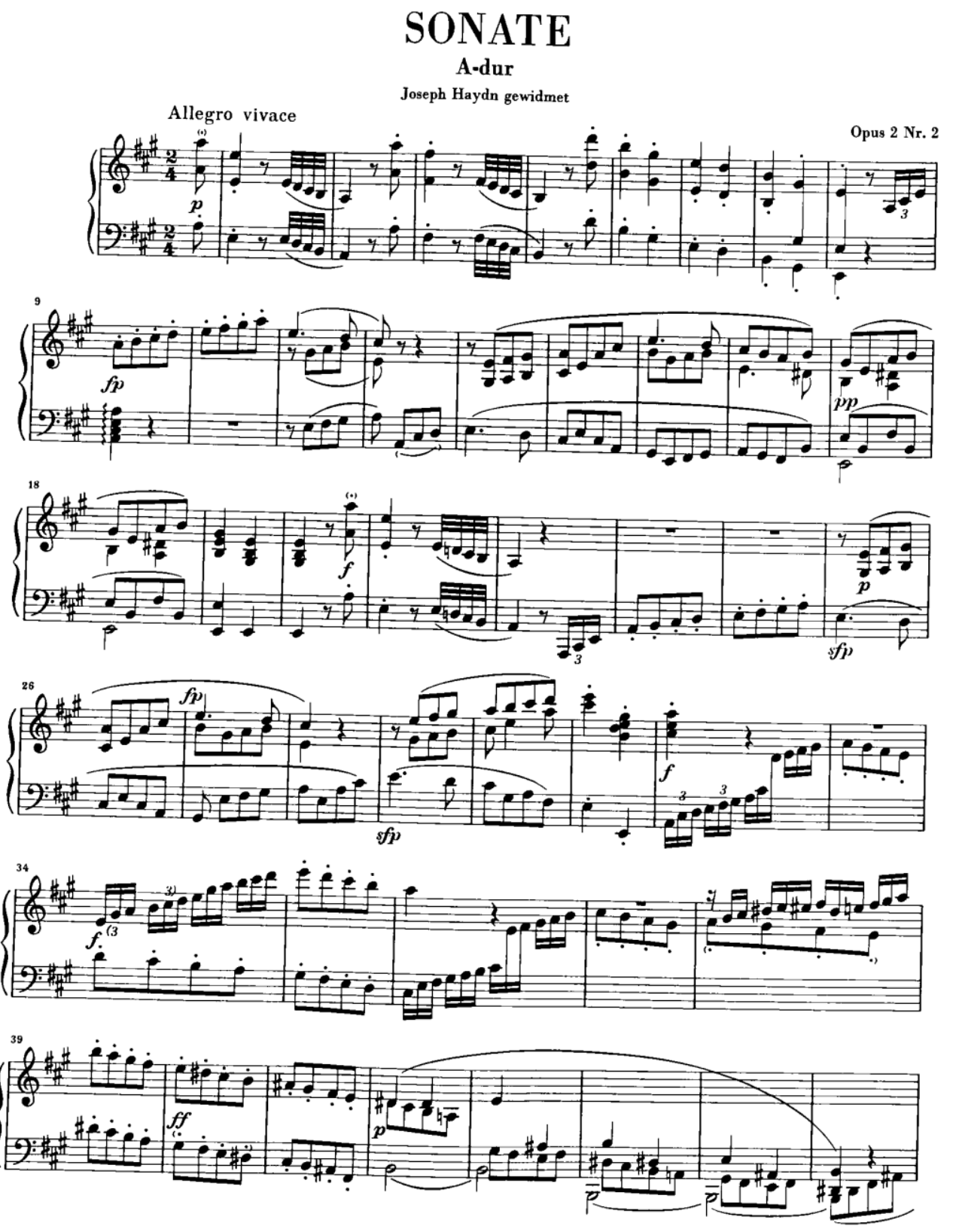




\section{SONATE}

C-dur

Joseph Haydn gewidmet
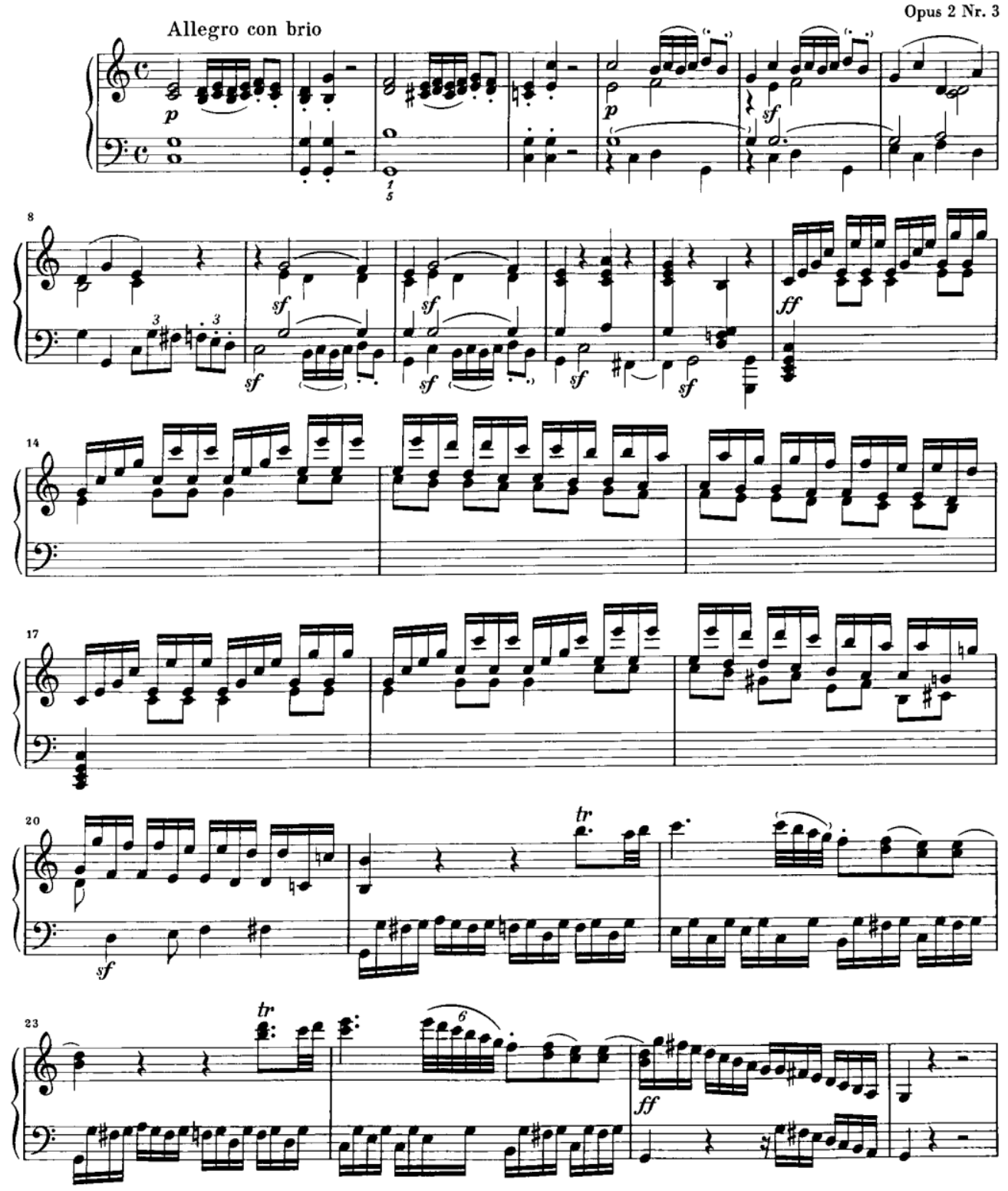

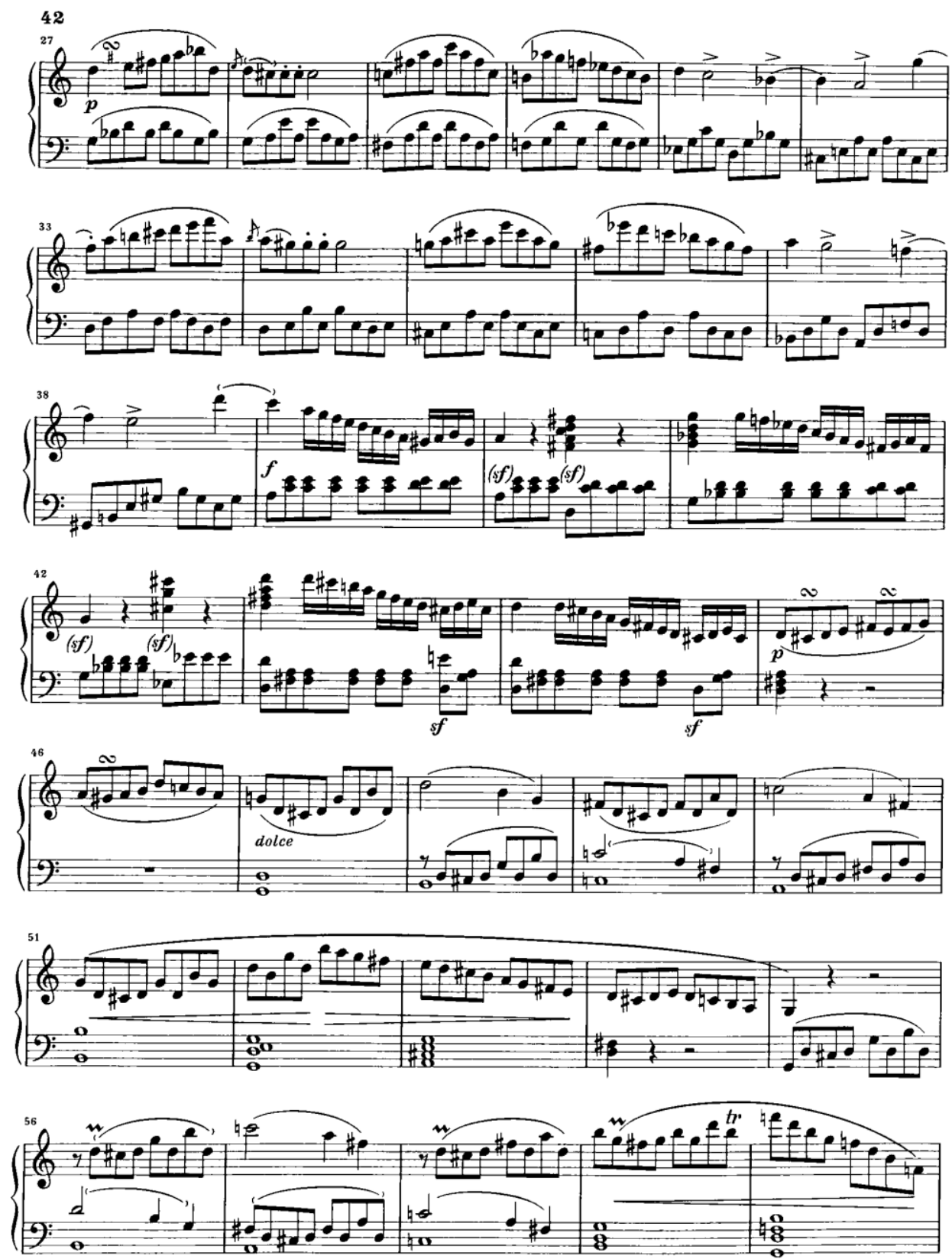
Example 8: Beethoven Sonata Op. 10, No. 1, Third Movement

102
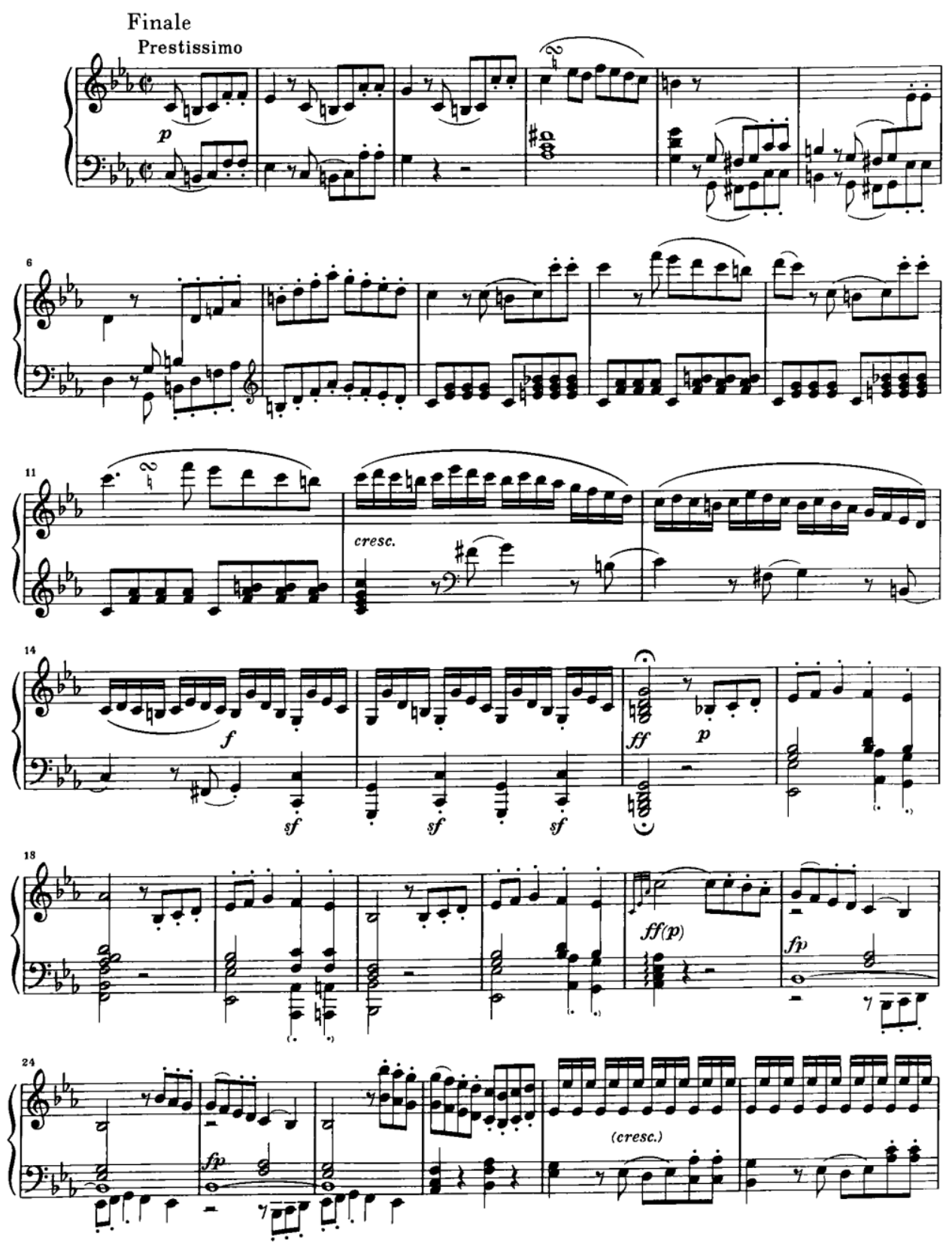
Example 9: Beethoven Piano Sonata Op. 10, No. 2

106

\section{SONATE}

F-dur

Der Grăfin Anna Margarete von Browne gewidmet

Opus $10 \mathrm{Nr} .2$
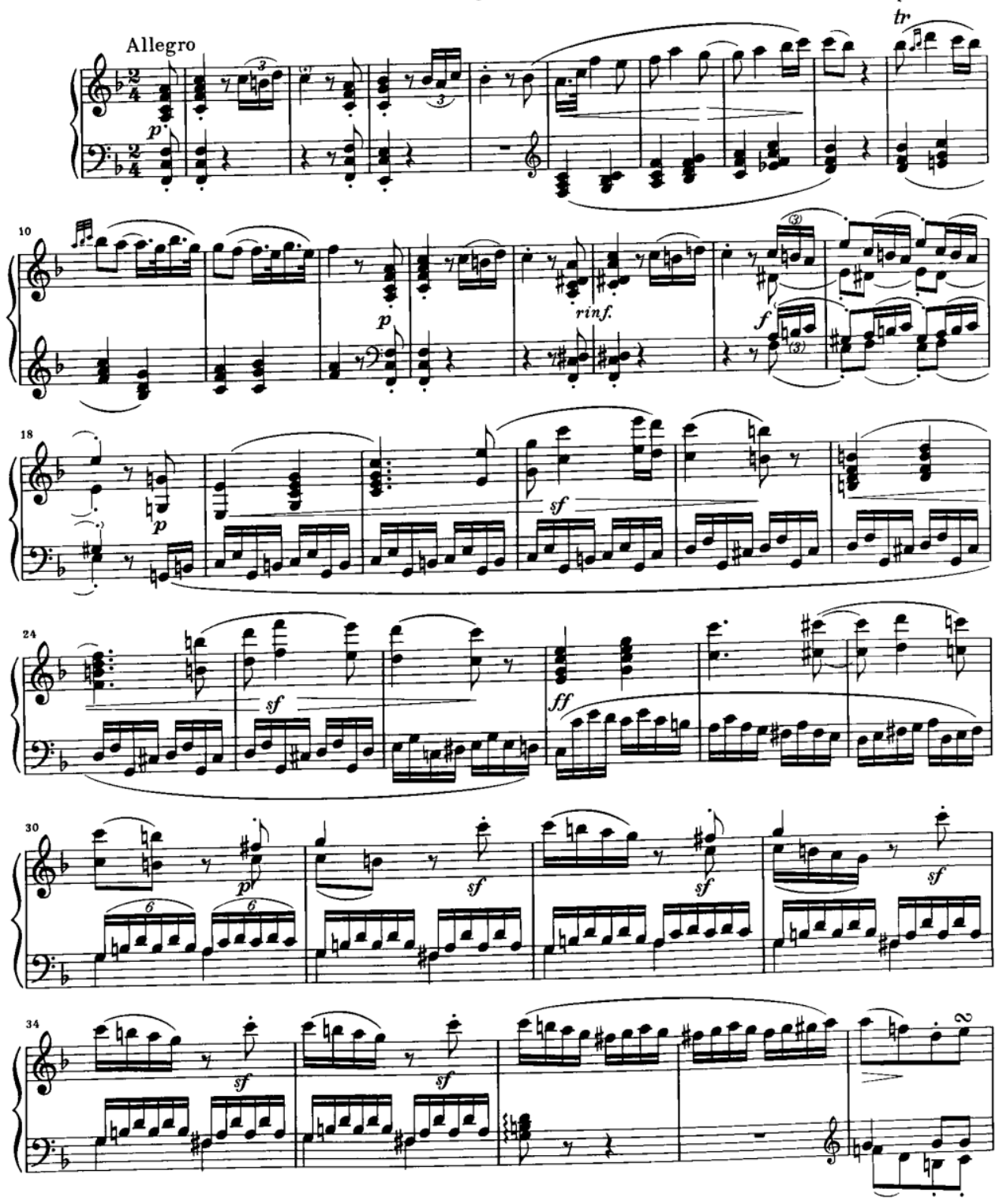

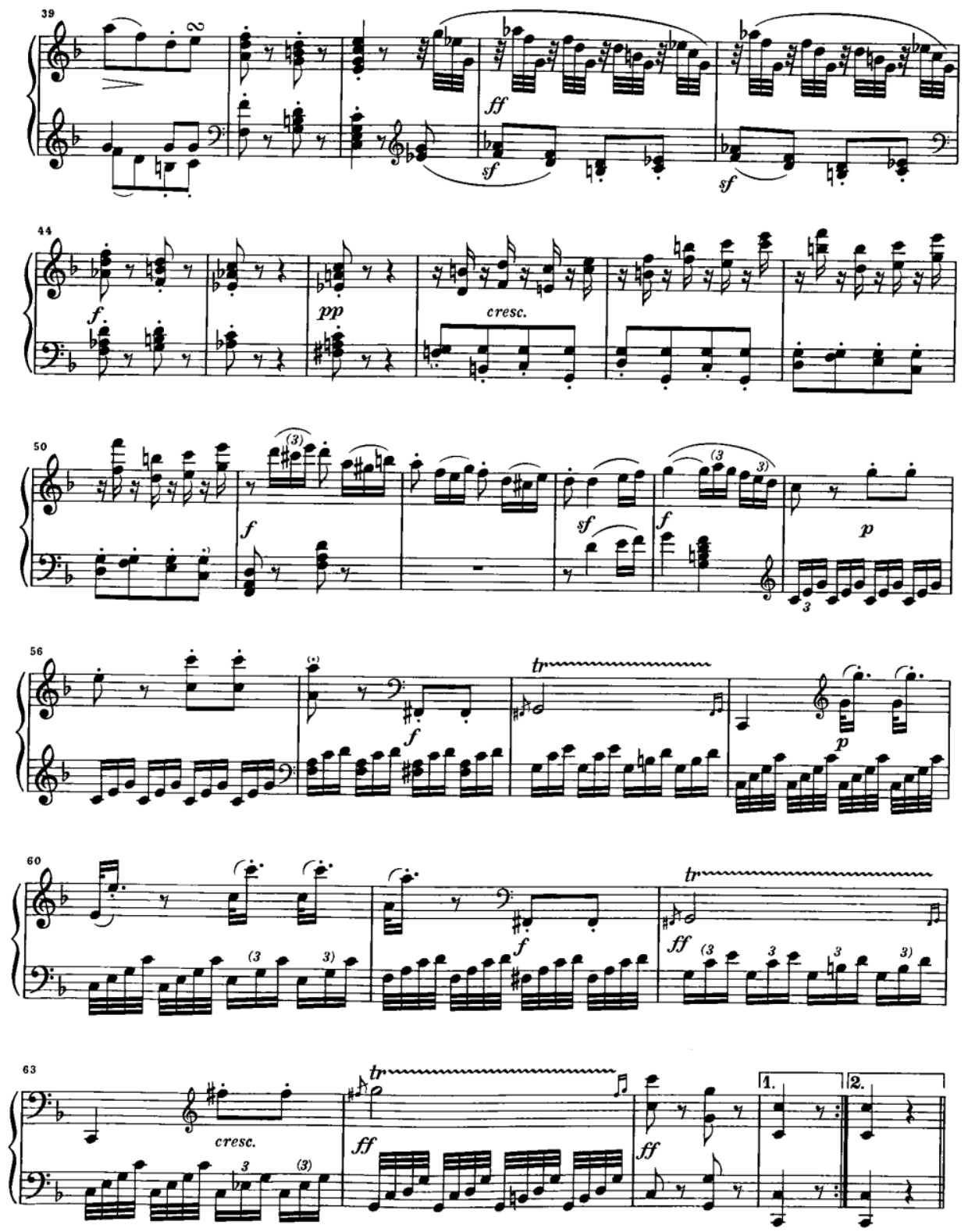
Example 10: Beethoven Piano Sonata Op. 31, No. 1

\section{SONATE}

G-dur
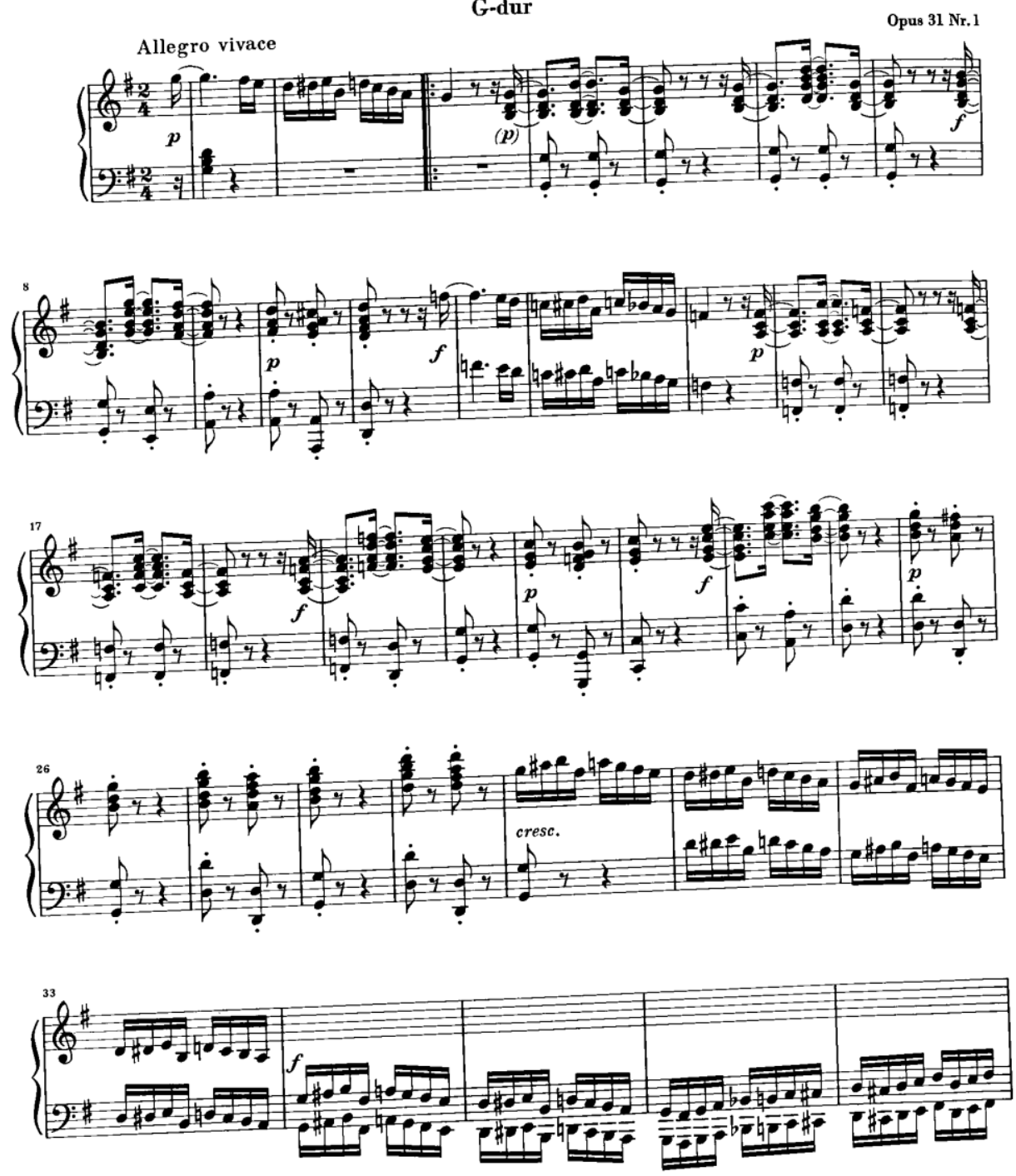

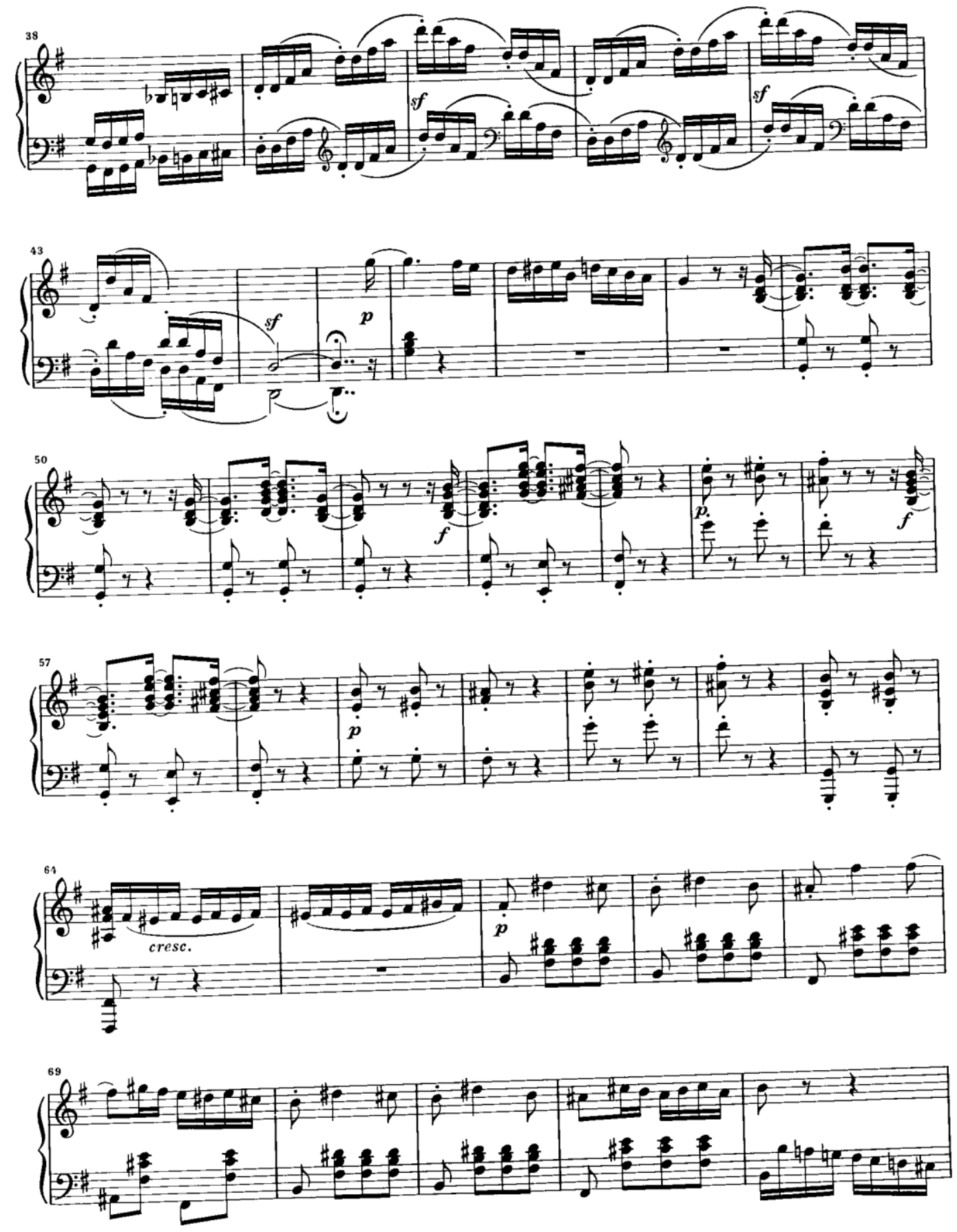
Example 11: Beethoven Piano Sonata Op. 31, No. 3

98

\section{SONATE}

Es-dur
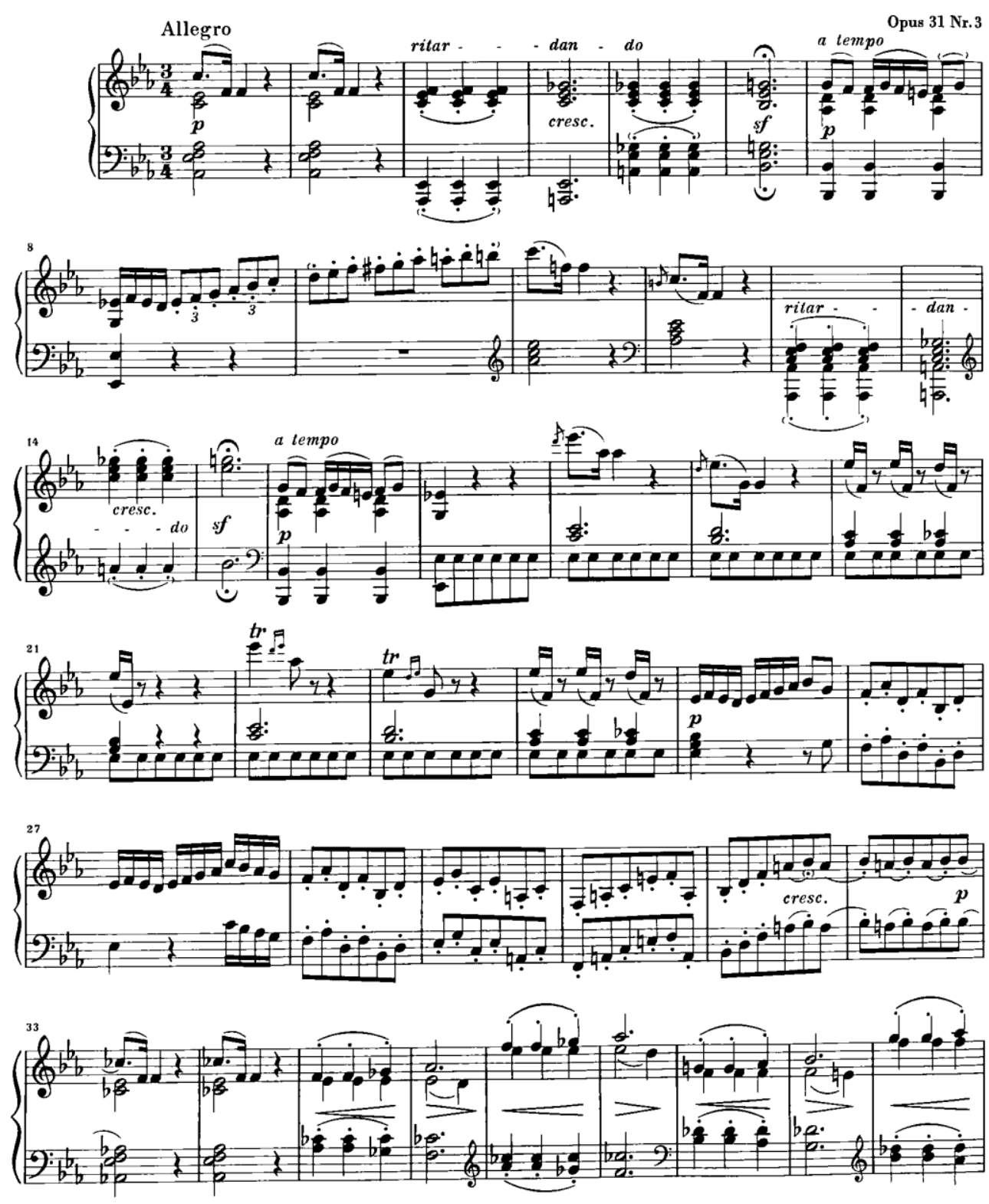


\section{Early Romantic Alienation in Beethoven's Christus am Ölberge}

Beethoven's only oratorio, Christus am Ölberge, written in 1803, tells the story of Jesus' agony in the garden at Gethsemane, expressing his sense of alienation from God the Father and from his disciples. Beethoven wrote the oratorio without a commission and worked for years on revisions despite a lack of interest from publishers. In Beethoven scholarship, this little-discussed work is connected to Beethoven's personal life through his Heiligenstadt Testament, which was written shortly before the oratorio. While I accept this link, I revise the standard interpretation which holds that both works represent Beethoven's heroism, suggesting instead that the intense alienation that Beethoven expresses in his letter and that Jesus feels in the garden provides a stronger basis for comparison. The experience of alienation was a central theme for the Early Romantics, who posited it as a defining characteristic of modern man.

\section{The Composition of Christus am Ölberge}

Beethoven composed Christus am Ölberge for his first engagement at the Theater-an-derWien in the spring of 1803, working closely with the poet Franz Xaver Huber (1755-1814) to produce the oratorio. The oratorio was the headline piece in the concert, which also featured the first and second symphonies and the third piano concerto. The concert took place, as per tradition, on the Tuesday of Holy Week, April 5.

The reception following its premiere was mixed. The Freymüthige said that "...the two symphonies and single passages in the oratorio were voted very beautiful, but the work in its entirety was too long, too artificial in structure and lacking expressiveness, especially in the vocal parts. The text, by F.X. Huber, seemed to have been as superficially written as the music." The Zeitung für die Elegante Welt reported that "there are a few admirable passages; an air of the 
Seraph with trombone accompaniment in particular makes an excellent effect." Finally, the Allgemeine Musikalische Zeitung wrote that the piece was received with "extraordinary approval." However, this praise was dampened in a later issue: "In the interest of truth, I am obliged to contradict a report in the Musikalische Zeitung; Beethoven's cantata did not please." ${ }^{97}$

Despite the mixed reviews, the oratorio was performed twice more that year, suggesting that it attained some level of popularity. Beethoven himself seemed to hold it in high regard. He spent time revising it in the year following its premiere, and looked to have it published for several years after that. After it was finally accepted for publication in 1808 , though, his original enthusiasm seems to have been tempered. He wrote of the text in 1811 that it "is extremely bad," but added that "he is a poor composer who is neither able nor anxious to extract as much good as possible even from an inferior text." ${ }^{, 88}$ Later in life, he recalled, apparently with some fondness, the intimate working environment he enjoyed with Huber: "Christus am Ölberg was written by me and the poet in a period of 14 days, but the poet was musical and had already written many things for music. I was able to consult with him at any moment.”

Beethoven's enthusiasm for writing and publishing this uncommissioned work has prompted scholars to link its subject matter to his personal life. The composer had written his famous Heiligenstadt Testament only months before composing Christus, a document which expresses his anxiety at the prospect of becoming deaf. At the prompting of his doctor, Beethoven had secluded himself in the summer of 1802 to the village of Heiligenstadt, outside Vienna, in a vain attempt to help his failing hearing. Beethoven seems to have grown depressed during this time, nearly to the point of suicide, which Alexander Wheelock Thayer ascribes to

\footnotetext{
${ }^{87}$ Elliot Forbes, Thayer's Life of Beethoven, Vol. I (Princeton: Princeton University Press, 1967): 330.

${ }^{88}$ Letter translations are from Emily Anderson, ed. The Letters of Beethoven (New York: Saint Martin's Press, 1961).
} 
"too many lonely hours in which to brood over his calamity." ${ }^{89}$ Just before he returned to Vienna in October 1802, he wrote the Testament. In the document, he describes his despair over his increasing deafness, his sense of isolation, and his hope, and also expresses a newfound resolve to persevere despite his problem. Beethoven's perseverance is characterized in this document by patience and endurance. He ascribes his ability to overcome his thoughts of suicide only through his faith in virtue and in art.

Barry Cooper compares the Testament to the oratorio libretto, proposing that certain lines are so similar that we could imagine the two were written together. In the following examples, the italics are from the Testament, the plain text from the oratorio libretto: ${ }^{90}$

For six years now I bave had an incurable condition I suffer sorely

a state of endless suffering suffering untold torment

I lead a miserable life 4 great are the torment, fear, and terror

If only I could be rid of it [my affliction] ${ }^{5}$ Take the cup of suffering from me

a burning anxiety comes over me like a feverish chill I am gripped by fear

[deatb] will still come too soon fear of imminent death

I had ... to spend my life alone I alone [atone for human guilt]

I am cut off from everything that is dear ${ }^{6}$ forsaken by his Father

I must live quite alone, like an outcast Here he is, the outcast

\footnotetext{
${ }^{89}$ Elliot Forbes, Thayer's Life of Beethoven, vol. I (Princeton University Press, 1967): 303.

${ }^{90}$ From Barry Cooper, "Beethoven's Oratorio and the Heiligenstadt Testament," The Beethoven Journal 10/1 (Spring 1995): 19-24.
} 
Cooper further pinpoints many themes shared between the two documents. These include "extreme and undeserved suffering, expressions of terror, fear of imminent death, and a sense of isolation and loneliness." He also finds a certain amount of optimism: "Throughout the struggle and the suffering, however, there remains the desire to do good and love mankind," and finally "there is the anticipation of ultimate triumph over adversity, with the struggle and agony being resolved in death and eternal joy."

In his biography of the composer, Maynard Solomon also connects the Testament and the oratorio. He casts both in terms of death and rebirth, with Beethoven's flight from suicide a heroically willed triumph. Solomon writes:

The Heiligenstadt Testament is a leave-taking-which is to say, a fresh start. Beethoven here enacted his own death in order that he might live again. He recreated himself in a new guise, self-sufficient and heroic. The testament is a funeral work, like the Joseph Cantata and Christ on the Mount of Olives. In a sense it is the literary prototype of the Eroica symphony, a portrait of the artist as hero, stricken by deafness, withdrawn from mankind, conquering his impulses to suicide, struggling against fate, hoping to find "but one day of pure joy." It is a daydream compounded of heroism, death, and rebirth, a reaffirmation of Beethoven's adherence to virtue and to the categorical imperative. ${ }^{92}$

Howard Smither, who has written the most comprehensive analysis of Christus am Ölberge, follows Maynard Solomon in setting the piece within the twin contexts of heroism and Beethoven's Testament. He sees the Jesus figure in Christus as a proto-hero, framing the oratorio as "Jesus' innocent suffering and heroic self-sacrifice." ${ }^{93}$ While the focus on Beethoven as a conquering hero has had tremendous staying power, such an interpretation requires some reworking of the themes in the Testament and of Christus. In the Testament, Beethoven emphasizes his resignation and endurance, not the active power of his will, attributing his

\footnotetext{
${ }^{91}$ Cooper, "Beethoven's Oratorio and the Heiligenstadt Testament," 19-24.

${ }_{92}$ Maynard Solomon, Beethoven, $2^{\text {nd }}$ edition (New York: Schirmer Books, 1998): 157-58.

${ }^{93}$ Howard Smither, A History of the Oratorio, Volume 3 (Chapel Hill: The University of North Carolina Press, 1987): 521.
} 
triumph to patience. A case for a resigned Beethoven hero has been made by Lewis Lockwood, who sees in the character of Florestan a parallel to the patient, enduring Beethoven of the Testament. ${ }^{94}$ Likewise, the analysis of Christus as representing a conquering heroism that defies death through resurrection is less than self-evident, since the work is a passion oratorio which leaves out Jesus' death and resurrection. The oratorio's central theme more closely aligns to the resigned hero, highlighting the resignation of Jesus' will to that of the Father.

Beyond differing conceptions of the heroic, a powerful sense of alienation runs through the Testament. Deriving from his encroaching deafness, Beethoven expresses it at several points, writing that, "Though born with a fiery, active temperament, even susceptible to the diversions of society, I was soon compelled to withdraw myself, to live alone," “...therefore forgive me when you see me draw back when I would have gladly mingled with you," and "I must live almost alone like one who has been banished, I can mix with society only as much as true necessity demands." When Beethoven's "banishment" casts him out into the countryside, he becomes alienated even from the pastoral, writing, "what a humiliation for me when someone standing next to me heard a flute in the distance and I heard nothing, or someone heard a shepherd singing and again I heard nothing. Such incidents drove me almost to despair, a little more of that and I would have ended my life —it was only my art that held me back." ${ }^{.95}$

While his sense of isolation could be understood as deriving solely from Beethoven's condition, there are some hints that the document expresses aspects of a thoughtfully considered

\footnotetext{
${ }^{94}$ Lewis Lockwood, "Beethoven, Florestan, and the Varieties of Heroism," in Beethoven and His World, ed. Scott Burnham and Michael P. Steinberg (Princeton: Princeton University Press, 2000): 27-47. Matthew Head elaborates on the gendered dynamics of the heroic in Fidelio in his "Beethoven Heroine: A Female Allegory of Music and Authorship in Egmont," $19^{\text {th }}$-Century Music 30/2 (Fall 2006): 97-132.

95 Translation from Forbes, Thayer's Life of Beethoven: 304-5. Beethoven's student Ferdinand Ries corroborates this, relaying an experience of being with the composer when he was unable to hear a shepherd playing a flute. See Forbes, Thayer's Life of Beethoven, 304.
} 
worldview that reaches beyond a simple biographical narrative of a depressed composer. For one, it seems to have been the product of some reflection and revision, rather than a hastily written letter. As Thayer notes, "The manuscript is so carefully written, and disfigured by so few erasures and corrections, as to prove the great pains taken with it before the copy was made." Within the document, Beethoven indicates his philosophical frame of mind in composing the Testament, writing, "Forced to become a philosopher already in my $28^{\text {th }}$ year, oh it is not easy, and for the artist much more difficult than for anyone else." And though the letter was ostensibly written as a will for his brothers Carl and Johann, Beethoven also addresses humankind several times, admonishing them for wronging him and hoping that "the world may become reconciled to me after my death." He also addresses God directly, petitioning him to see his good intentions: "thou seest my inmost soul, thou knowest that therein dwells the love of mankind and the desire to do good."

If Beethoven is thinking philosophically at points in the Testament, attempting to reconcile his life in relation to prevalent ideas at the time about subjectivity, then his position as an alienated subject — and particularly as an alienated artist-philosopher — can be more powerfully articulated within the context of Early Romanticism. The Early Romantics experienced alienation from society, from nature, and from God, theorizing its sources, consequences, and remedies. Understood within this context, the Heiligenstadt Testament and Christus both reach beyond the biographical, becoming allegories of the modern, alienated subject. 


\section{Alienation in Early Romanticism}

The Early Romantics have been called "a fundamentally disenchanted war-generation" (eine gründlich entzauberte Kriegsgeneration), an orientation which they recognized and theorized themselves. ${ }^{96}$ The alienation they felt had two major sources. One of these came out of the radical use of reason. In the wake of the pantheism controversy, the Early Romantics remained strongly in support of the independent use of reason, even radicalizing it, but they also recognized the dangers that stemmed from the power of criticism. ${ }^{97}$ This was because criticism led to the exposure of all beliefs as nothing more than prejudices, inevitably resulting in a debilitating skepticism and ultimately to a fractured self. In addition, the desire for radical individual freedom led to the control and manipulation of the outside world for the individual's purposes, which took away nature's beauty and mystery. Finally, criticism required the individual to question institutions of authority and to reject their strictures when they did not meet the requirements of rational inquiry, thus isolating oneself from society. ${ }^{98}$

Beyond the problems deriving from the trajectory of philosophical inquiry, the other major source of alienation for the Early Romantics stemmed from the effects of civil society. One of these was the mechanized abuse of human labor, which turned man into a machine in order to extract the greatest utility from him. As Friedrich Schlegel wrote:

\footnotetext{
${ }^{96}$ Marianne Thalmann, Ludwig Tieck: der romantische Weltmann aus Berlin (Bern, 1955): 106.

${ }^{97}$ See the Introduction to the dissertation for a summary of this controversy.

${ }^{98}$ This last position is held by the philosopher Johann Gottlieb Fichte (1762-1814), who argues in his Grundlage der gesamten Wissenschaftslehre (1794) that the individual is obliged to revolt if state laws do not accord with moral law. See Klaus Peter, "History and Moral Imperatives: The Contradictions of Political Romanticism," in The Literature of German Romanticism, ed. Dennis F. Mahoney (Rochester, NY: Camden House, 2004): 193-95. For a summary of Fichte and Kant as they relate to the alienation of the Early Romantics, See Azade Seyhan, "What is Romanticism, and Where did it Come From?" In The Cambridge Companion to German Romanticism, ed. Nicholas Saul (Cambridge: Cambridge University Press, 2009): 1-20. For the Early Romantics on alienation from nature, see Alison Stone, "Alienation from Nature and Early German Romanticism," Ethical Theory and Moral Practice 17 (2014): 46; Frederick C. Beiser, Enlightenment, Revolution, Romanticism: The Genesis of Modern German Political Thought, 1790-1800, (Cambridge: Harvard University Press, 1992): 229-31.
} 
The bourgeois man is first and foremost fashioned and turned into a machine. He is happy even if he has become only a number in a political sum, and he can be called in every respect perfect if he has transformed himself from a person into a cipher. As it is with the individual, so with the masses. They eat, marry, produce children, become old, and so on to infinity. Pure life simply for the sake of life is the source of baseness, and everything is base that has nothing of the world-spirit of philosophy and poetry. ${ }^{99}$

In addition to their view of such crass materialism, the Early Romantics

questioned the ideal of egoism which had become commonplace by the end of the

eighteenth century. ${ }^{100}$ They argued for a renewed commitment to community in the face

of such isolation. As Novalis wrote, "Flight from the communal spirit is death!",101

Instead, the Frühromantiker advocated a concept of society in which citizens would be

reconciled to themselves, each other, and nature. For them, Bildung provided through art

was a primary means of reconciliation. ${ }^{102}$

By parsing out the views of the Early Romantics, secondary literature commonly

recognizes a three-fold alienation for them - the separation of the individual from

oneself, from nature, and from the community — preceded by a fourth: what Bernadette

Malinowski calls "the estrangement of the individual from established religion."103 This

fourth kind of alienation has been subsumed into the term "disenchantment," most

\footnotetext{
${ }^{99}$ Friedrich Schlegel, Kritische Ausgabe Vol. VIII, (München: F. Schöningh, 1958): 50. Quoted in Beiser, Enlightenment, Revolution, Romanticism, 234.

100 Peter, "History and Moral Imperatives: The Contradictions of Political Romanticism," 198. See Novalis, FichteStudien (1795-96) and Glauben und Liebe no. 36. Cited in Beiser, Enlightenment, Revolution, Romanticism, 235.

${ }^{101}$ Novalis, Blütenstaub no. 82, in Schriften, II, 451. Quoted in Beiser, Enlightenment, Revolution, Romanticism, 235.

102 Beiser, Enlightenment, Revolution, Romanticism, 259.

103 Bernadette Malinowski, "German Romantic Poetry in Theory and Practice: The Schlegel Brothers, Schelling, Tieck, Novalis, Eichendorff, Brentano, and Heine," in The Literature of German Romanticism, ed. Dennis F. Mahoney (Camden House, 2004): 147-48. For this threefold division, also see Beiser, The Romantic Imperative, 31; On alienation from nature, see Alison Stone, “Alienation from Nature and Early German Romanticism," 51-52.
} 
notably by sociologist Max Weber, who theorizes it as a historical and social process of secularization and rationalization rather than as a subjective experience of the world. ${ }^{104}$

Charles Taylor has approached the topic from the viewpoint of intellectual history in his The Secular Age, identifying its sources in eighteenth-century thought and proposing that to live in a disenchanted world means being a "buffered self," that is, having "closed the porous boundary between inside (thought) and outside (nature, the physical)..."105 While such subjects have the power of being able to order the world around them, Taylor also identifies the dangers of the buffered self, including the experience of living in "a prison, making us blind or insensitive to whatever lies beyond this ordered human world and its instrumental-rational projects." This prison can leave subjects feeling as if "we are missing something, cut off from something, that we are living behind a screen."106

Musicologist Daniel Chua has written about disenchantment as it relates to music. Following Weber's and sociologist Theodor Adorno's writings, he theorizes that like many other aspects of modern life, music itself has been disenchanted, that is, rationalized, analyzed, and cut off from the unifying theory of the universe found in the medieval conception of the harmony of the spheres. According to Chua, music has been rationalized by Gallileo, who isolated music, prodded it with experiments, and tuned it

\footnotetext{
${ }^{104}$ The term "disenchantment" also has a strong association with narratives of progress, both optimistic and pessimistic. For a literature review of this narrative, see Sara Lyons, "The Disenchantment/Re-Enchantment of the World: Aesthetics, Secularization, and the Gods of Greece from Friedrich Schiller to Walter Pater," The Modern Language Review 109/4 (October 2014): 873-95. Weber based his idea on that of Friedrich Schiller. Schiller, who was one of the first to enunciate the split of modern man from nature, referred to the "de-divinization of nature" (die entgötterte Natur) in his 1788 poem "The Gods of Greece" (Die Gotter Griechenlands). See Jeffrey E. Green, "Two Meanings of Disenchantment: Sociological Condition vs. Philosophical Act-Reassessing Max Weber's Thesis of the Disenchantment of the World," Philosophy \& Theology 17 1/2 (2005): 51-84.

${ }^{105}$ Charles Taylor, A Secular Age, (Cambridge: The Belknap Press of Harvard University Press, 2007): 300.

${ }^{106}$ Ibid, 302.
} 
for maximum efficiency. As a result, music has become divided from a once-whole world, a dead object of science, merely another casualty of instrumental rationality. It was the Early Romantics who recognized this state of affairs, experiencing alienation in a disenchanted world, and who looked to art as a mode of re-enchantment. Chua diagnoses their aestheticism as "a symptom of a disenchanted world rather than a solution". ${ }^{107}$

While their art certainly symptomizes disenchantment, the Early Romantics were not writing naively. Instead, they were radically self-aware, recognizing that the literature and art they produced was both a symptom of their alienation and a signpost on the way to reunification. Therefore, understanding Christus am Ölberge as a work which expresses alienation and also hopes for a future of reconciliation keeps with these two pillars of Early Romantic thought.

\section{The Oratorio in $18^{\text {th }}$-century Germany}

The oratorio in eighteenth-century German-speaking Europe fell into two categories, the lyric and the dramatic. The dramatic oratorio, consistent with Italian oratorio, preceded the lyric and was the dominant form in Roman Catholic areas. It usually consisted of a Biblical text without any additional narration or commentary, and included multiple speaking characters as well as an unfolding plot. The lyric form, which arose in the middle of the eighteenth century, was based on an Enlightenment theory which held that the oratorio should produce feelings of awe and reverence toward the subject matter. In his Allgemeine Theorie der Schönen Künste (1771-74), Johann Georg Sulzer defines the oratorio in terms of the lyric type:

${ }^{107}$ Daniel Chua, Absolute Music and the Construction of Meaning, (Cambridge: Cambridge University Press, 1999): 12-22. 
Oratorium. (Poetry; music.) A spiritual, but completely lyric and short drama, which is performed with music, for use in divine service on high feast days. The designation of lyric drama indicates that here no gradually developing action, with striking events, intrigues, and interwoven ventures takes place, as in the drama made for a play. The oratorio assumes various personages who are strongly moved by the noble religious subject of the feast that is being celebrated and who express their sentiments about it, now singly, now together, in a very emphatic manner. The purpose of this drama is to penetrate the hearts of the listeners with similar sentiments... ${ }^{108}$

Sulzer not only ignored the dramatic oratorio in his entry on the oratorio, but he also disdained the subgenre in his entry on church music, writing that "In some German Protestant churches, they have even come to the tasteless notion of sometimes making church music dramatic. They perform oratorios...in which recitatives, arias, and duets continually alternate among one another in the operatic manner...An invention of a senseless head, which to the shame of good taste is still retained in many places."109 The distinction between lyric and dramatic oratorio was a partisan issue, not only for Sulzer but for Heinrich Christoph Koch as well, who wrote disparagingly of the dramatic oratorio in his Musikalisches Lexikon (1802): "[Its] recitatives, arias, and choruses, which often, however, as with our modern church music in general, depart too much from the noble simplicity that should distinguish our music for divine service and incline too much toward the style of operatic music."110

In keeping with distinctions made in the eighteenth century, Smither divides the oratorio into the lyric and dramatic based on differences in the librettos. He considers Haydn's The Creation (Die Schöpfung) oratorio from 1798 to be unique because of its largely narrative nature, and Beethoven's Christus am Ölberge to be dramatic, because it exhibits the literary hallmarksnamed characters, narration, an active rather than reflective chorus, and a moving plot— that

\footnotetext{
108 Johann Georg Sulzer, Allgemeine Theorie der Schönen Künste, 2/2 (Leipzig: M.G. Weidmann, 1773-75): 360. Quoted in Howard Smither, A History of the Oratorio, Volume 3 (Chapel Hill: The University of North Carolina Press, 1987), 337.

${ }^{109}$ Sulzer, Allgemeine Theorie, 2/2: 19. Quoted in Smither, Vol. 3, 339.

${ }^{110}$ Heinrich Christoph Koch, Musikalisches Lexikon, vol. 2 (Frankfort am Main: Bey A. Hermann dem Jungern, 1802): 1098.
} 
define the dramatic genre. Haydn's Creation has few characters, instead depicting God's action in the external events of the creation. Some contemporary critics regarded Die Schöpfung to represent the new Romantic art through its depictions of these events. As Richard Will writes, "More novel is the suggestion that material representations [in Die Schöpfung] communicate the kind of fleeting, indeterminate meaning the early Romantics associated with music and especially with instrumental music." ${ }^{111}$ Critics pointed to the gap in signification between the libretto and its musical representations in Die Schöpfung in order to suggest that the indeterminacy created by this gap represented the infinite, that ideal state which always remains just out of reach. Alienation lies on the other side of the coin in this formulation, which contrasts a present state of alienation with a hopeful future perfection.

Beethoven's oratorio bears little resemblance to Die Schöpfung, its immediate predecessor in Viennese oratorio. Die Schöpfung is written on an Old Testament subject, the creation story in Genesis, while Beethoven's Christus tells the story of Christ's time in the garden at Gethsemane. Beethoven's music follows the text's focus on the figure of Jesus by focusing the story and music on his inner emotions. In this way, his oratorio is more like the Protestant, Enlightenment lyric oratorio, which had developed through the course of the eighteenth century. Georg Feder writes about how Enlightenment ideas influenced Protestant church music:

The Enlightenment held that the chief function of all church music was "edification." Everything that seemed to be edifying was to be kept; everything else was either to be abolished or to be

\footnotetext{
${ }^{111}$ Richard Will, The Characteristic Symphony in the Age of Haydn and Beethoven (Cambridge: Cambridge University Press, 2002): 147. For more discussion on the role of criticism in the emergence of Romanticism, see Will, 146-49.
} 
revised. To "edify" meant to induce feelings of reverence, whether they were only sentimental or more elevating in nature. ${ }^{112}$

Because of this shared affinity with Protestant oratorio, Carl Heinrich Graun's (17041759) oratorio Der Tod Jesu is a closer relative to that of Beethoven. Composed in 1755 on a libretto by K.W. Ramler (1725-1798), Der Tod Jesu quickly achieved popularity, was performed every year on Good Friday for over a century afterward in Berlin, and was known throughout German-speaking Europe. ${ }^{113}$ Beethoven probably knew it from its widespread fame, but also certainly knew parts of it from its inclusion in Sulzer's article on recitative in his Allgemeine Theorie der schönen Künste. ${ }^{114}$

Der Tod Jesu narrates all of Christ's passion, including the agony at Gethsemane. Chorales dot the work, but most of the musical interest comes in the various recitatives, which advance the plot, and the choruses, which elaborate the emotions of the moment.Feder's assessment of the influence of Enlightenment ideals of "edification" on Protestant church music, which emphasized the importance of feelings for edification, is fully in evidence in this oratorio. In writing the libretto, Ramler assumed the listener's knowledge of the events of the passion story. His text takes on the voice of the congregation, voicing their presence as if the events of the passion are taking place before them, and anticipating their collective response. His libretto is distinctive for this aspect, which allows him to direct the audience toward appropriate and edifying emotions. The first six numbers consider Jesus' time praying at Gethsemane, and therefore are directly comparable to Beethoven's oratorio.

\footnotetext{
${ }^{112}$ Georg Feder, "Decline and Restoration," trans. Reinhard G. Pauly, in Protestant Church Music, ed. Friedrich Blume (New York: W.W. Norton, 1974): 323.

${ }^{113}$ Howard Smither, "Oratorio." Grove Music Online.

${ }^{114}$ Richard A. Kramer, "Beethoven and Carl Heinrich Graun," in Beethoven Studies, ed. Alan Tyson, Vol. I (W.W. Norton, 1974): 38. Noted in Smither, Vol. 3, 519.
} 
Christus tells a smaller section of the passion story, largely concentrating on the progress of Jesus' prayer in the garden at Gethsemane, from his struggle with his fate on the cross to its acceptance, as well as the events of the Gospel story immediately after this. The first half of the oratorio presents the emotions of Jesus, as well as commentary from and dialogue with the angel sent from God, a seraph. Following an orchestral introduction, Jesus, knowing that his hour is approaching, begins by praying to his Father, asking for strength, power, and comfort. He then gives praise to the Father, telling Him that he wants to fulfill his destiny, and further expresses the suffering that he is currently enduring. In the second scene, a seraph enters, observes Jesus' suffering, and sings a song of praise with a choir of angels. In scene 3, Jesus speaks to the seraph, inquiring about the will of his Father. The seraph relays the message from God the Father which states that mankind cannot be redeemed without his sacrifice. Jesus accepts this message and they sing together about the greatness of God's love and the suffering of Christ. Finally, in the fourth scene Jesus welcomes death as the soldiers prepare to abduct him. While I will only be discussing the music to this point, the only action in the remainder of the oratorio consists of Peter attempting to defend Jesus and the soldiers succeeding in apprehending him.

Graun's oratorio goes beyond Beethoven's in setting a reflective, meditative text, but is very similar in employing text-painting techniques that accentuate the inner emotions of Christ's passion. The action moves slowly, and much of the text centers on the suffering Christ. The most prominent difference is the portrayal of the figure of Jesus. Graun and Ramler paint a Christ whose suffering is immediately and simultaneously shared by all. Beethoven's Jesus, on the other hand, is abandoned and outcast. His Jesus suffers while alone, and the audience watches him from afar, unable to participate. 


\section{Jesus in Graun's Der Tod Jesu}

In Der Tod Jesu, the first six numbers concern his time in the garden at Gethsemane. A chorus at No. 2 sings of Jesus' agony while there. The chorus consecutively sings "his breath is faint” (Sein Odem ist Schwach), "his days are cut short” (Seine Tage sind abgekürzet), "His soul is full of misery" (Seine Seele ist voll Jammer), and "His life is near to hell" (Sein Leben ist nahe bei der Hölle), repeating each phrase before moving on to the next. The text-painting at "his breath is faint" is itself breathless, coming in short, repeated two-note phrases as "is faint" is repeated. Similarly, "his days are cut short," which begins in imitative polyphony, loses its way, ending in a homophony that is accentuated by notes cut short with eighth-note rests. "His soul is full of misery" receives a chromatic, descending and angular melody as a melisma on "misery". Finally, "His life is near to hell" is punctuated by a pivot harmony between C minor and A major on "hell," marking the word as a point of emphasis. ${ }^{115}$

Taken together, these four instances of text-painting show the variety and ingenuity of Graun's compositional techniques for complementing the text. Each musical instance is tailored to the meaning of the text at that point: breathless music comes at "his breath is faint"; a musical technique cuts short at "his days are cut short"; "misery" receives a miserable, chromatic melody; and finally, the differently inflected harmony at "Hell" disorients. ${ }^{116}$ Graun's expressive techniques serve to draw the congregation closer together, to further achieve the emotional edification by uniting in music Ramler's libretto.

The recitative and aria at Nos. 3 and 4 also take place at Gethsemane. The accompanied recitative begins with a narration of Jesus in the garden, followed by the words of Jesus himself,

\footnotetext{
115 Example 1.

${ }^{116} \mathrm{My}$ interpretation of Graun's use of text-painting corresponds closely to that of Smither. See Oratorio, Vol. 3, 406-427.
} 
drawn from scripture. The narrative voice here seems to be spatially situated, dropping in from afar and drawing ever closer. Initially, the narrator questions who he sees in the garden, asking "who is the excruciatingly, slowly dying one?" (Wer ist der peinlich langsam Sterbende?) and "is it my Jesus?" (ist das mein Jesus?).

After identifying Jesus, the narrator continues to emphasize Jesus' agony, moving from the second-person to the third-person to refer to him. "You hesitate, you tremble like a sinner" (du zagst, du zitterst gleich dem Sünder), "He sinks" (er sinkt), and "his heart works to beat in his chest" (Sein Herz in Arbeit fliegt aus seiner Höhle) all highlight the immediacy of Jesus' suffering. The music throughout this recitative reflects the text. Repeated, palpitating staccatos accompany the words as they turn from identifying Jesus to reflecting on his suffering. ${ }^{117}$ Once again, Graun uses text-painting in order to draw the congregation together toward greater edification.

Following a chorale No. 5 which expresses the hope of the faithful for salvation at the time of death, the recitative No. 6, “Ach! Mein Immanuel!" continues the passion story. Following the chorale, the narrator and Jesus are still in the garden at Gethsemane. The Gospel accounts play a more prominent role in this number, which includes several details taken from the different Gospels. The scene is set with the image of Jesus deeply bent over (tief gebückt), speaking to his Father: "Father, let this hour pass away" (Lass Vater, lass Vater diese Stunde, lass sie vorüber gehn). He continues by asking for the suffering to cease: "Take away the bitter cup from my mouth!" (nimm weg den bittern Kelch von meinem Munde!). Finally, he accepts his fate, saying "You will not take it?...Your will should come to pass" (Du nimmst ihn nicht?...dein Wille soll geschehn!). Following this moment, the narrator returns, describing Jesus

${ }^{117}$ See example 2 . 
rising up from the ground, "cheered" (Erheitert) and strengthened by an angel (gestärckt durch eines Engels Hand). ${ }^{118}$

The music of the recitative reflects the text directly at many points. Toward the beginning, it intensifies Jesus' suffering. The bass and treble are chromatically inflected, rising by half steps a minor sixth apart as Jesus "struggles against death" (ringt dem Tod entgegen) and “cries loudly" (jammert lauf). Jesus' melody at this point takes precedence over the harmony as he pleads with his Father to take the cup of suffering from him. At "take (the cup) Father" (lass Vater), the melodic interval outlines a diminished fourth; as Jesus twice repeats "take it away" (nimm weg), the melody is repeated, and is raised to a higher note the second time. This figure is repeated at a higher pitch a third time, peaking on the word "bitter" (bittern) and resting on an elongated g-flat minor harmony.

Jesus' next line is “you will not take it?" (du nimmst ihn nicht?). It is at this pivotal line of text, when Jesus receives the understanding that he must drink the cup of suffering, where the mood of Graun's music turns. To this point, the music had accentuated the suffering of Christ; as Jesus receives an answer from his father, however, the music becomes upbeat. The rhythm of his vocal line here becomes lively with dotted rhythmic figures, and the phrase cadences decisively on a major harmony, thus ending the moment of Christ's suffering at the garden.

This moment, at which Jesus rises from his prayer, cheered by the angel, departs from scripture. No longer suffering, Ramler's Jesus appears to have conquered fear with little difficulty. Following this moment, he is fearless and magnanimous (unerschrocken...grossmüthig). While Luke is the only one of the synoptics to describe the angel

${ }^{118}$ See example 3. 
strengthening Jesus (Lk. 22:43), even he does not mention Jesus feeling cheered at this moment. This added detail is significant, for it signifies a de-emphasis on Jesus' suffering after the garden scene. While Ramler's Jesus resolutely faces suffering while praying at Gethsemane, as he rises from prayer, he no longer needs the strength to overcome any further suffering. Instead, following this scene, his suffering is no longer mentioned, and the music reflects his heroic overcoming.

As the oratorio progresses, the narrator touches on aspects of Christian faith: the virtues of forgiveness, patience, and piety, the suffering of Jesus on the cross, and the necessity of following his example. Throughout, the work plays up the emotions of the audience, an effect that is heightened by describing in detail Jesus' death on the cross. In response, the audience members are called upon to reflect on Jesus' pain, leading them in the end to become repentant sinners.

\section{Jesus in Beethoven's Christus am Ölberge}

Unlike the oratorio of Graun and Ramler, Beethoven's and Huber's work conveys a sense of alienation, both through the figure of Jesus and through musical choices. Der Tod Jesu begins with a collective four-part chorale which addresses Jesus, setting up the expectation that the community of the congregation is working together. In Christus, the orchestral introduction immediately sets a different tone from Der Tod Jesu, conveying an alienated subjectivity and foreshadowing Jesus's own isolation. The key is e-flat minor and the tempo is slow; the first notes we hear are a somber rising arpeggio in the low brass. The strings continue with a pianissimo theme, pitched low, that comes to a complete stop on a half cadence after four measures. A fragment of a different theme, a repeated syncopated e-flat, is then played three 
times in the trumpets with string accompaniment, and the music comes to a second half cadence after four more measures. This fragment is repeated three more times by the flutes, clarinets, and bassoons, with an elongation in the phrase, quickly crescendoing to a forte. Finally, the phrase comes to an end on a full cadence, followed by the timpani alone, playing slow, piano eighth notes for a full measure.

Similar music follows throughout the remainder of the introduction, maintaining the slow, minor feel, the low range, and the short disassociated phrases. But for two short instances, there is little respite from the gloom. One comes toward the middle of the introduction, a g-flat major cantabile theme in a higher register, framed as if by quotation marks by the slow, piano eighth notes in the timpani. The other is at the end, just before Jesus enters the scene; here, the bassoons play an undulating $\mathrm{g}$ major arpeggio, as if lifting a veil for the first stage entrance. ${ }^{119}$

Jesus' opening words take place in the context of prayer in the garden, directed at Jehovah, his Father (mein Vater). The first three scenes feature Jesus appealing to his Father and interacting with the angel, a seraph, who has been sent to communicate with the Son. In the first scene, the text emphasizes the difficulty, but also the necessity, of Jesus' sacrifice. In the opening recitative, he tells his Father of the great suffering he is enduring, saying that "Ah, how anxiety and dread powerfully seize my heart! I suffer greatly, my father! O see, have mercy on me!” (Ach sieh', wie Bangigkeit, wie Todesangst mein Herz mit Macht ergrieft! Ich leide sehr, mein Vater! O sieh', erbarm' dich mein). Even here, however, Jesus understands what must take place, saying that "it now approaches, the hour of my suffering, already chosen for me, even as the world was wrested from chaos at your behest" (Sie nahet nun, die Stunde meiner Leiden, von mir erkoren schon, noch eh' die Welt auf dein Geheiss dem Chaos sich entwand). Despite his

\footnotetext{
${ }^{119}$ See example 4.
} 
suffering and the necessity of the sacrifice, it is clear that Jesus himself is making the choice to undergo the sacrifice, and that it is his own free will that allows him to intercede for humanity. He says "I want to be the intermediary, I want to purge, I alone, humankind's guilt" (Vermittler will ich sein, ich büsse, ich allein, der Menschen Schuld). The first aria focuses on Jesus' pain. He sings of his unsettled soul (Meine Seele ist erschüttert) and his fear of the near grave (die Angst beim nahen Grab), and he humbly begs his Father to take away the suffering (Tief gebeugt und kläglich fleht dein Sohn hinauf zu dir...nimm den Leidenskelch von mir).

The music through this first recitative and aria often paints moods in broad strokes, continuing the gloom from the introduction along with occasional moments of clarity. Both the recitative and the aria, however, also contain specific instances of text-painting. In the recitative, the glory of God the Father, at the words "even as the world was wrested from chaos at your behest," receives appropriately grand music. The syncopated rhythm here powers a crescendo, which erupts into a fortissimo, Maestoso section with double-dotted rhythms and sforzandi accents. Later, as Jesus is proclaiming his willingness to undergo suffering, his words "I alone" are set to a tense tritone melodic interval accompanied by two staccato forte chords. ${ }^{120}$

Following these instances, Beethoven composes transitional music that leads into the more intensely emotional aria. Beginning at "Ah, how anxiety and dread powerfully seize my heart!" the music is marked Adagio agitato, and a pulsating rhythm played between the basses and the higher strings marks the building of tension. When Jesus cries "I suffer greatly, my father!", the melody rises by a step for four consecutive downbeats, each one an appoggiatura, as the orchestra plays rising arpeggios that end in sforzandi. A crescendo follows, culminating in an

\footnotetext{
${ }^{120}$ See example 5 .
} 
orchestral tutti on a crashing, fully diminished fortissimo chord as Jesus seems to exhaust himself with an octave drop in the melody, singing "Have mercy on me!"121

The second scene introduces the character of the seraph. Her message echoes that of Jesus' in the first scene. She looks down upon him, comments on his terrible pain and imminent death, and reiterates that he dies willingly in order to save mankind and give them eternal life (Er ist bereit, den martervollsten Tod zu sterben, damit die Menschen, die er liebt, vom Tode aufer stehen und ewig, ewig leben). The seraph then sings a song of praise to God along with a chorus of angels: "Praise the redeemer's goodness, praise, people, his grace! (Preist des Erlösers Güte, preist, Menschen, seine Huld!). The music here again paints in broad strokes, emphasizes the goodness of God with celebratory music. When the text turns from the virtues of love, hope, and faith, to warning of the dangers of Hell (Die frech entehren das Blut, das für sie floss, sie trifft der Fluch des Richters, Verdammung ist ihr Loos), the music suddenly and frighteningly turns to minor.

The third scene features the interaction of Jesus and the seraph, with Jesus asking the angel whether his Father's will allows for the cup of suffering to pass from him. She tells Jesus that his sacrifice is necessary to redeem mankind: "Thus says Jehovah: Until the holy secret of reconciliation is fulfilled, mankind remains a corrupt race and bereft of eternal life" (So spricht Jehovah: Eh’ nicht erfüllet ist das heilige Geheimniss der Versöhnung, so lange bleibt das menschliche Geschlecht verworfen und beraubt des ew'gen Lebens). Time seems to stand still during this declaration, as the angel chants on a single tone, and sustained winds hold the

${ }^{121}$ See example 6. 
seraph's line in suspension. ${ }^{122}$ The gravity of the divine declaration gives way to a glimpse of future peace and rest when the music takes a turn at the mention of "eternal life." At this point, the half-note sforzandi accompanying the seraph's words change to a choral texture of quarter and eighth-notes, marked piano and containing an expressive suspension figure. Jesus replies to the seraph by submitting to his Father's will, again not without difficulty. Following the recitative in which the seraph proclaims Jehovah's will and Jesus accepts his fate, the two sing a duet which further expresses the pain that Jesus feels and his willingness to take on the responsibility.

The music in the duet marks a change from Jesus' earlier aria, where his fear and pain are clearly present in the accompaniment. From the beginning, the music here is gentler, marked adagio molto and presenting a stately double-dotted theme, along with slowly changing harmonies, a major key, and a cantabile cello melody. The text, however, is not so clearly peaceful, and Beethoven adjusts as the music progresses. When the seraph sings of the great fear which she shares with Jesus, saying "I tremble, and the chill of the grave which he feels fans me as well" (Ich bebe, und mich selbst umwehen die Grabesschauer, die er fühlt), for example, the music trembles along with her, trading thirty-second repeated notes between treble and bass string instruments. The predominant affect here, however, is gentle and sweet, reflecting the overarching theme in one line of the aria text which is repeated several times by Beethoven: "Great are the agony, the anxiety, the horror, that God's hand outpours on him/me: but greater still is his love, with which his/my heart surrounds the world" (Gross sind die Qual, die Angst, die Schrecken, die Gottes Hand auf ihn/mich ergiesst: doch grösser noch ist seine Liebe, mit der

\footnotetext{
${ }^{122}$ This is probably the moment which the reviewer in the Zeitung für die Elegante Welt praised, writing that "there are a few admirable passages; an air of the Seraph with trombone accompaniment in particular makes an excellent effect." Thayer muses that this could also be the part that Beethoven was writing in bed when Ries found him lying there at dawn the morning of the performance. See Thayer-Forbes, Vol. I, 328-29.
} 
sein/mein Herz die Welt umschliesst!). Love conquers all here, but it has not yet won its victory, for Christ has yet to be crucified. The music recognizes this in a monophonic line in the strings at the end of the duet. This music does not fit with what came before, sounding menacing instead of affirming with its minor pianissimo, taken at a faster tempo.

Years after composing Christus, Beethoven acknowledged that the text is less than ideal. Indeed, events occur more than once, particularly Jesus willingly submitting himself to the sacrifice, a feature which stalls its dramatic and contemplative progress. But Beethoven also writes that "he is a poor composer who is neither able nor anxious to extract as much good as possible even from an inferior text." And with the music, Beethoven manages to provide a sense of dramatic progress, even as the text stalls.

\section{Jesus as Alienated Sufferer in Beethoven's Christus am Ölberge}

In Christus, Jesus' suffering and his alienation are connected from the beginning. In the music, the spare orchestral introduction, with its low range, thin monophony and homophony, and frequent silences, immediately indicates a sense of distance, not closeness. The text reinforces this, particularly in the three explicit references to Jesus' alienation. Unlike Jesus in Graun's oratorio, this figure experiences an acute isolation. Graun and Ramler's Jesus is always accompanied by the choir, which shares his anguish throughout. Jesus in Christus is alone. We watch him, helpless and from afar, as he confronts his fate by himself. His isolation is inextricably linked to suffering for this Jesus, a pain which is greater than that of Graun's oratorio. In Der Tod Jesu, Jesus easily overcomes his grief. In Christus, he confronts it for much longer. While he hopes in the peace of the future, he cannot escape the suffering of the present. 
He trusts in his Father's will, but feels the fear of death nonetheless. Let us explore the three references to the alienation of Jesus in Christus.

In Christus am Ölberge, Jesus' alienation is referenced three times. The first comes from Jesus himself, in the opening recitative as he prays to his Father. He tells his Father of his willingness to be the one who atones for the sins of mankind, saying, "O father! I appear before your call. I want to be the intermediary, I want to purge, I alone, humankind's guilt" (O Vater! Ich erschein' auf deiner Ruf. Vermittler will ich sein, ich büsse, ich allein, der Menschen Schuld). By itself, the text here seems to downplay the reference, mentioning it only in passing within a sentence about Jesus' intercession for mankind. But Beethoven's music buttresses the importance of the two words, setting them apart by means of the melody, harmony, dynamics, articulations, and timbre at this moment. This line of text, set to a dry recitative after an orchestral interlude, begins with a melody that rises to a high note of E-flat three times, and a harmony that increases in dissonance as the line progresses. While the first E-flat is approached and left by consonant melodic intervals of a minor sixth and a perfect fourth, the second E-flat high note descends to an A natural, outlining a tritone in the melody. The tension continues to increase after this, coming to a head on the second syllable of "allein," where the melody climbs to an E-natural from a B-flat, outlining a melodic tritone a half step higher than the previous one. At the same time, the strings play two staccato, forte chromatically ascending diminished chords, adding to the emphasis of the moment. ${ }^{123}$

The second instance comes with the entrance of the seraph, looking down on Jesus while singing a recitative. One of her first observations is about Jesus' alienation from his Father, saying "Jehovah's son lies here, his face shown subdued in the dust, completely left by his

\footnotetext{
${ }^{123}$ See example 5.
} 
father, and suffering unspeakable agony" (Jehovah Sohn liegt hier, sein Antlitz lief in Staub gedrückt, vom Vater ganz verlassen, und leidet unnennbare Qual). The seraph's words link his alienation to his suffering, making it clear that these two ideas go together. As she sings "verlassen," the harmony intensifies from a dominant seventh chord to a fully diminished chord. Finally, the soldiers call Jesus "the exile" (der Verbannte) in the fifth scene, indicating his separation from society.

Because Jesus' alienation is placed in sharp relief by the music and connected to his suffering in the first two recitatives, his further agony can be understood as a result of his alienation. The connection between Jesus' status as an outcast and his suffering carries a double meaning. On the one hand, such a portrayal is consistent with Church theology and doctrine, which places emphasis on the divine mission of Christ the savior, who had to suffer death on the cross in order to save humankind from their sins. This mission was his alone, the Church teaches, and it as well as the Gospel accounts emphasize that he willingly endured suffering in order to fulfill his mission. But his alienated suffering also has a clear resonance to both Beethoven's life and to Early Romanticism at the time.

\section{Comparison of Graun's and Beethoven's Portrayals of Jesus}

Jesus' alienation in Christus is thrown into even sharper relief in comparison to Graun's Jesus. Graun's oratorio, coming out of the Protestant tradition, does not emphasize that Christ is forsaken by the world. Though, like Christus am Ölberge, it portrays the inner emotions, particular the suffering, of Christ during his passion, he never quite seems alone. Perhaps because of the Protestant emphasis on maintaining a personal relationship with Jesus, he is often referred to as "mein Jesus" in Ramler's text. The narrator always seems to be next to Jesus, his 
constant companion, in contrast to Beethoven's version, in which Jesus' forsaken status is at the forefront.

Comparing the figures of Jesus in Ramler's text and in Huber's text reveals some similarities. They both refer to scripture, both narrative descriptions of the events at the garden, and the words of Jesus himself as he prays at Gethsemane. Both texts note the same details, including the sweat that looks like blood, as well as Jesus' stature, bowed low. They also both include his words as he tells of his sorrowful soul, "even to death," when he asks his Father to take the cup of suffering from him, and as he determines to do his father's will. The similarities in the descriptions are not surprising, for they both rely on the Gospel accounts for their details. However, they both combine accounts. The detail of Jesus' sweat falling like drops of blood comes from Luke 22:44, and Mark and Matthew both relate his words "my soul is very sorrowful, even to death," (Mt. 26:38, Mk. 14:34), but Luke does not.

The contrast with Beethoven's Jesus figure is pronounced at the moment when he rises from his prayer in the garden. While Ramler's Jesus feels cheered and fearless at this moment, Beethoven's Jesus perseveres despite his agony and terror. In Christus, Jesus asks the seraph if his Father can take the fear of death from him (Nimmt er des Todes Schrecknisse von mir?) The angel responds that the deed must be done, for mankind remains unredeemed until Christ's fate is fulfilled (So spricht Jehovah: Eh' nicht erfüllet ist das heilige Geheimniss der Versöhnung, so lange bleibt das menschliche Geschlecht verworfen und beraubt des ew'gen Lebens). Jesus accepts this saying, but not without understanding the hardship it entails for him. He replies with “Pour over me the river of suffering, only don't be angry with Adam's children" (Giess' uber mich den Strom der Leiden, nur zürne Adams Kindern nicht). 
The twin portrayals of Jesus sets into relief the nearly half-century that separates the two works. The audience for Graun's oratorio is clearly meant to suffer together, in a sociable community that reflects its Enlightenment underpinnings, while Beethoven's Christ lives alone, bereft of any community at all. This difference is striking. Der Tod Jesu offers a Christ whose agony spearheads a community that suffers alongside him, while Christus presents a Christ who suffers alone, cut off from the world even as he saves it. Jesus in Christus does offer hope, however. He eventually manages to communicate with his Father, and his disciples come to him even though it means their own agony and physical death. Still, the two Christs underscore the difference a generation can make in how cultural texts reflect the particular understandings of their social worlds. Enlightenment sociability gives way to Romantic isolation; shared suffering gives in to individual agony; community to alienation.

Beethoven's emphasis on the alienation of Jesus is consistent with the themes that run through the early sonatas, discussed in the previous chapter. In those sonatas, difficulties in comprehension come out of sudden disruptions, discontinuities, or a lack of musical context. These difficulties point to a common interest in the idea of communication among the Early Romantics, stemming from a distrust of the seductive writings of the Aufklärung. Such incomprehension, however, always seems to be resolvable, signifying hope for the future. But a breakdown in the ability for people to communicate effectively with each other signaled the more general breakdown in societal relations. Similarly, social alienation, like that of Beethoven and Jesus, also symbolizes a breakdown in social relationships, resulting in social outcasts and the famous Romantic "wanderer." Like his early sonatas, however, and contrary to common claims about Romanticism's yearning to return to the past, the story of Jesus' passion offers hope for the future: for Christianity, it is hope in the Resurrection and the promise of eternal life; for 
Beethoven in his Testament, as for the Early Romantics, hope lies in reconciliation with the world.

The portrayal of Jesus' fear and pain within the context of his isolation in Christus mirrors the themes of Beethoven's later Goethe songs. The next chapter will explore some of these, but will also look at how Beethoven's compositional techniques in his Goethe songs innovate in order to express emotions that are in keeping with themes of lonely suffering and hope for a better future. While the songs are in some ways heirs to an Enlightenment past, we will see how they also break with that past in order to express new worldviews. 
Example 1: Graun Der Tod Jesu No. 2 Chorus

2

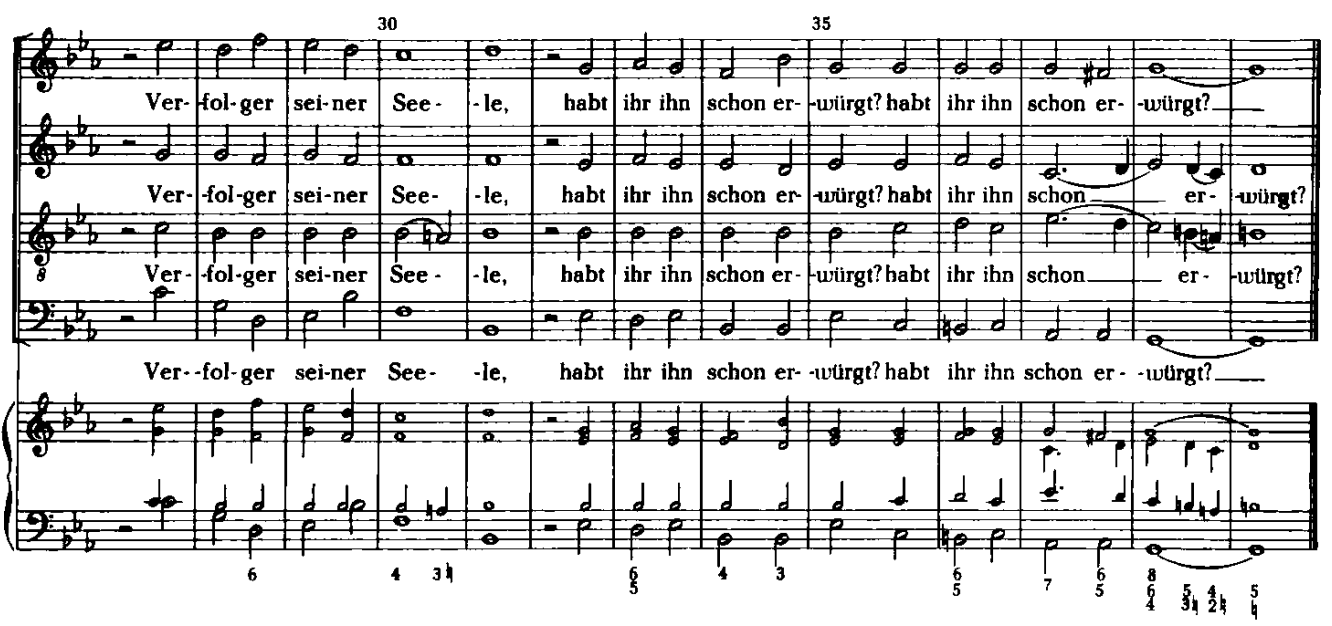

[II] Tutti
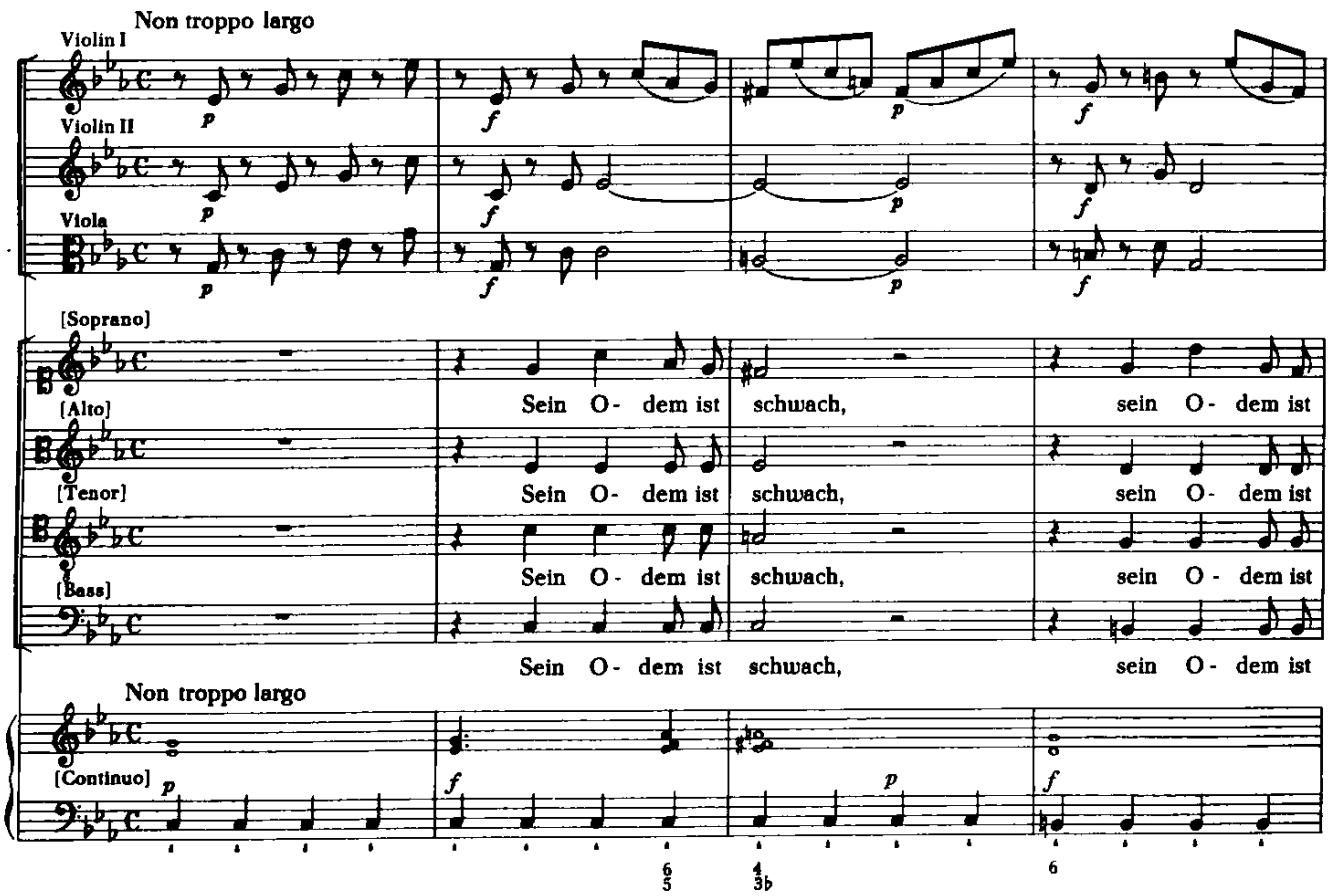


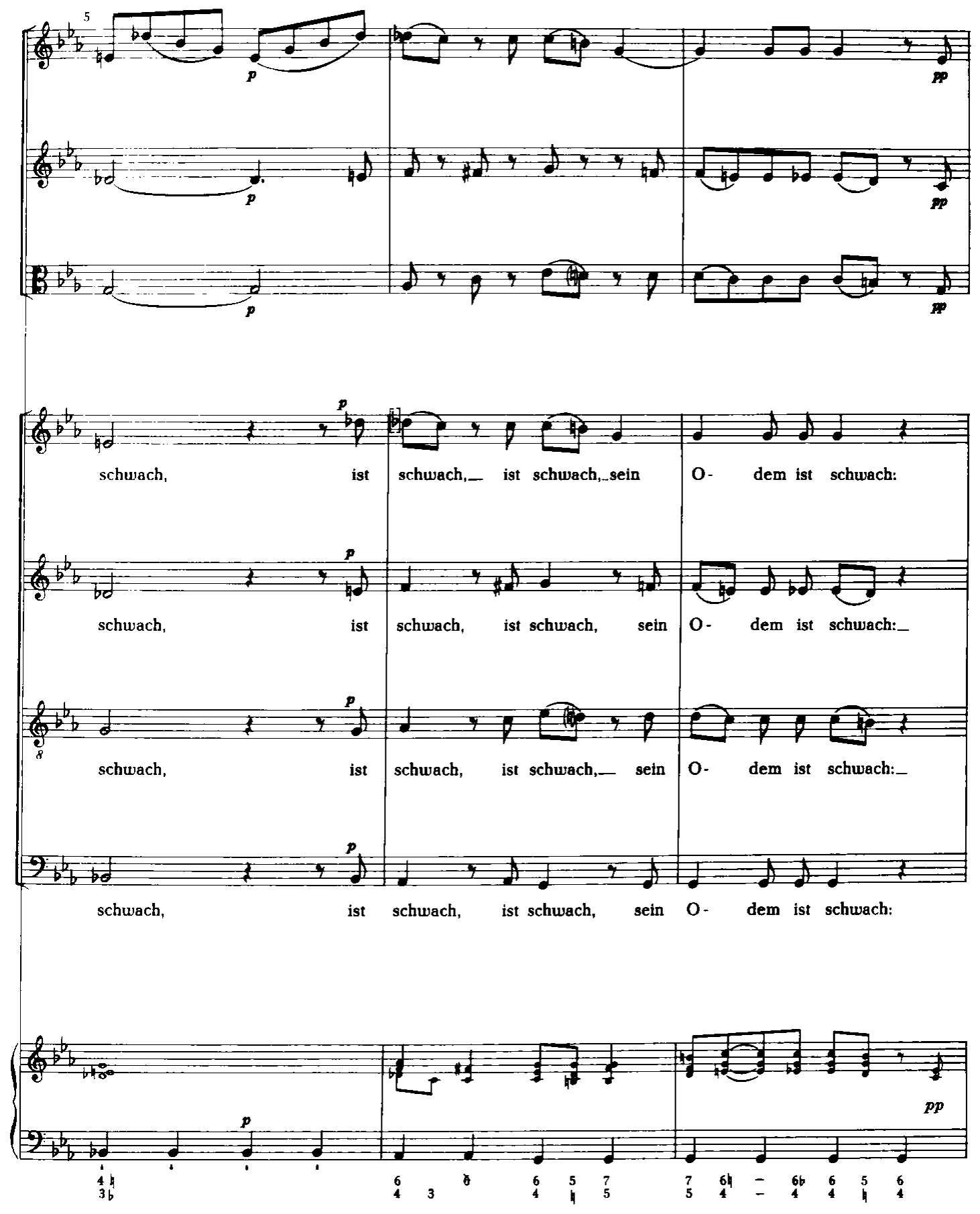




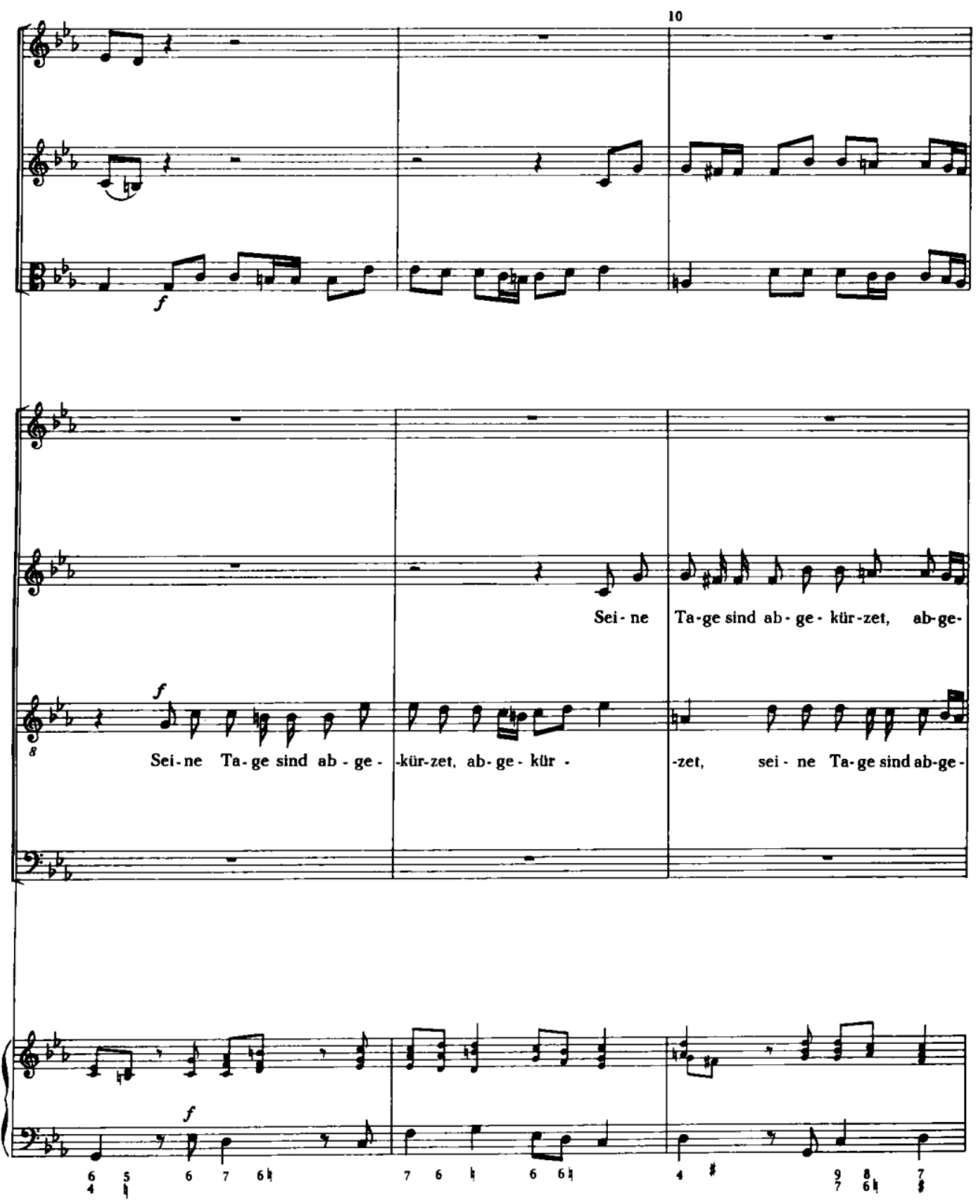



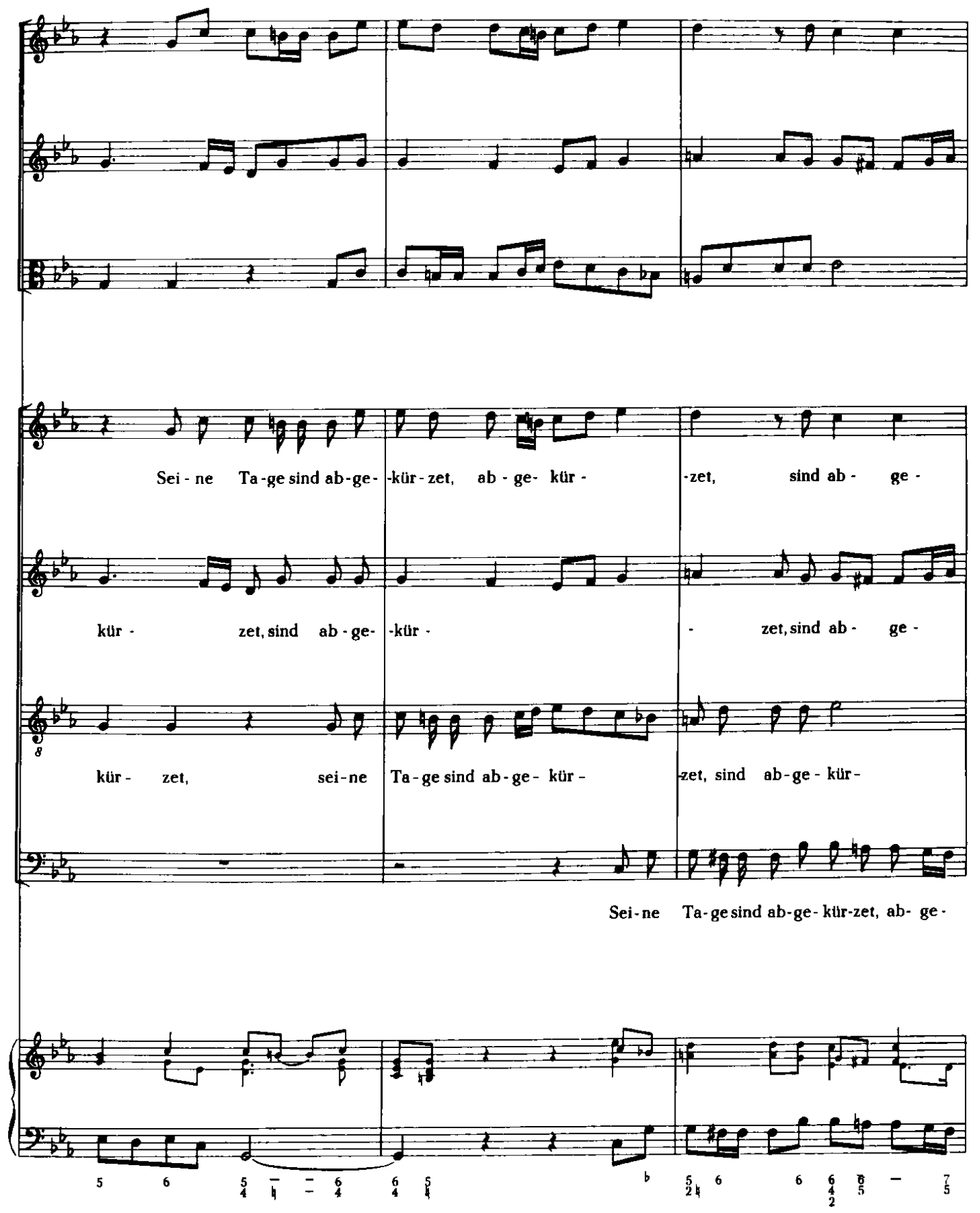

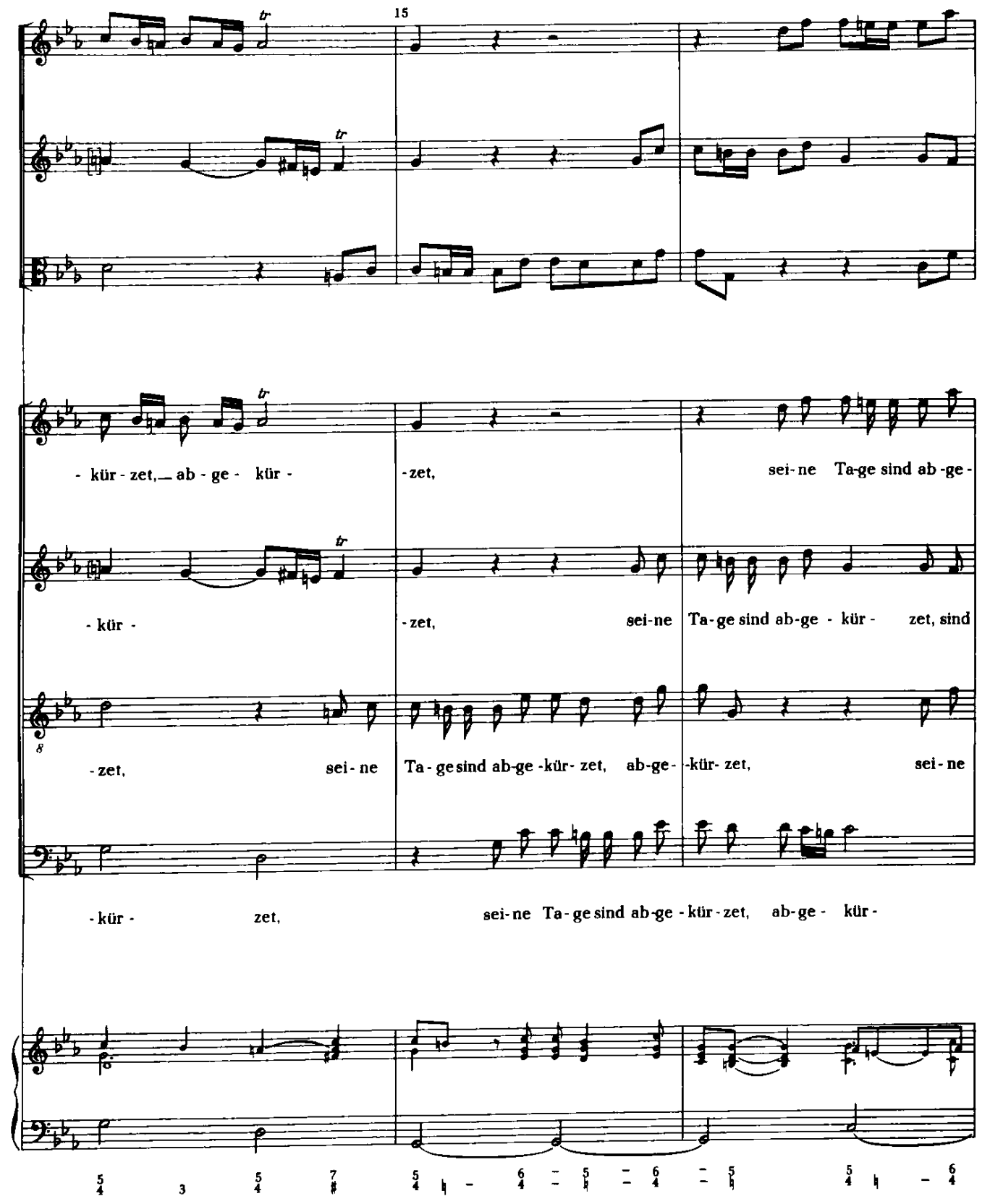


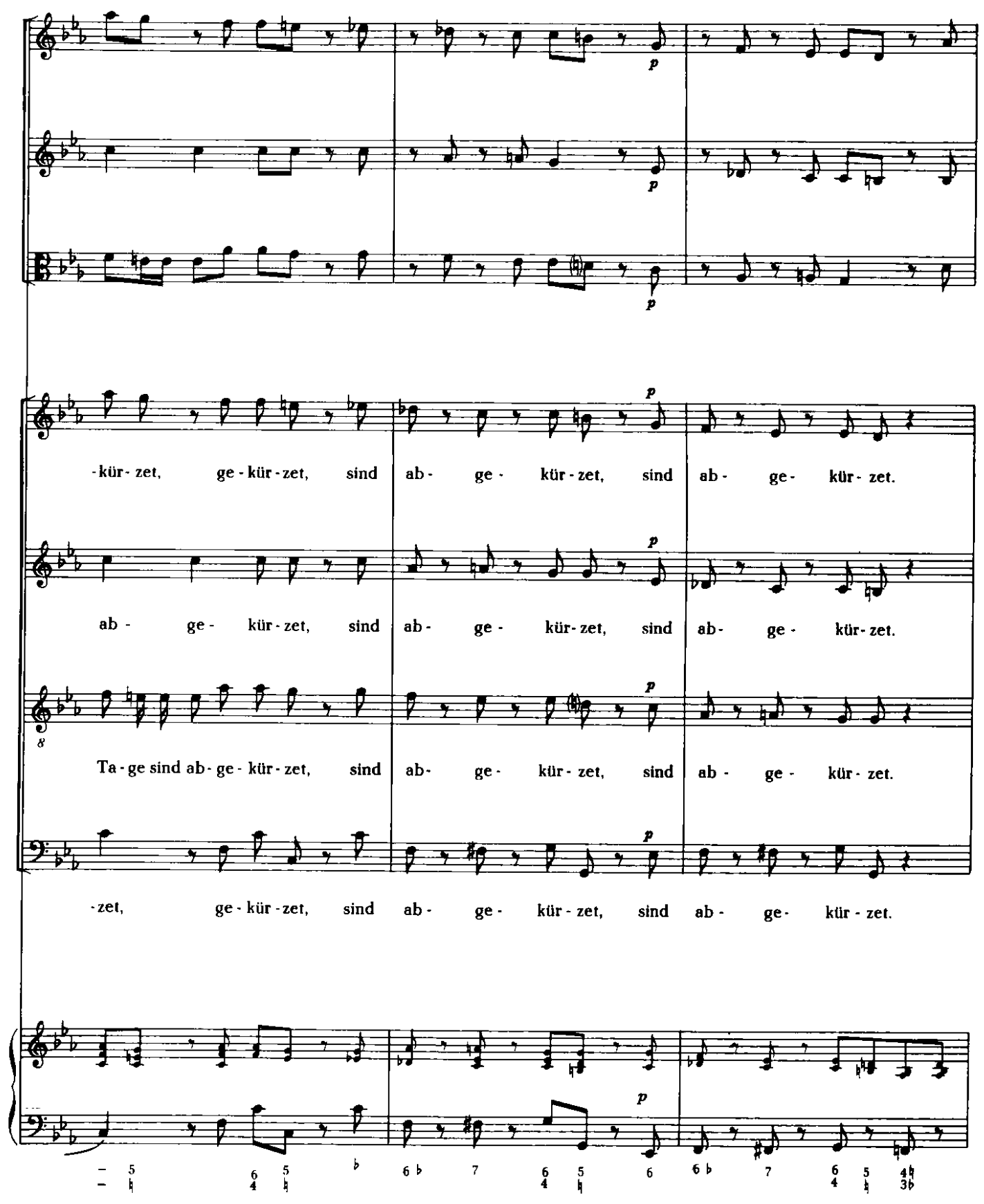




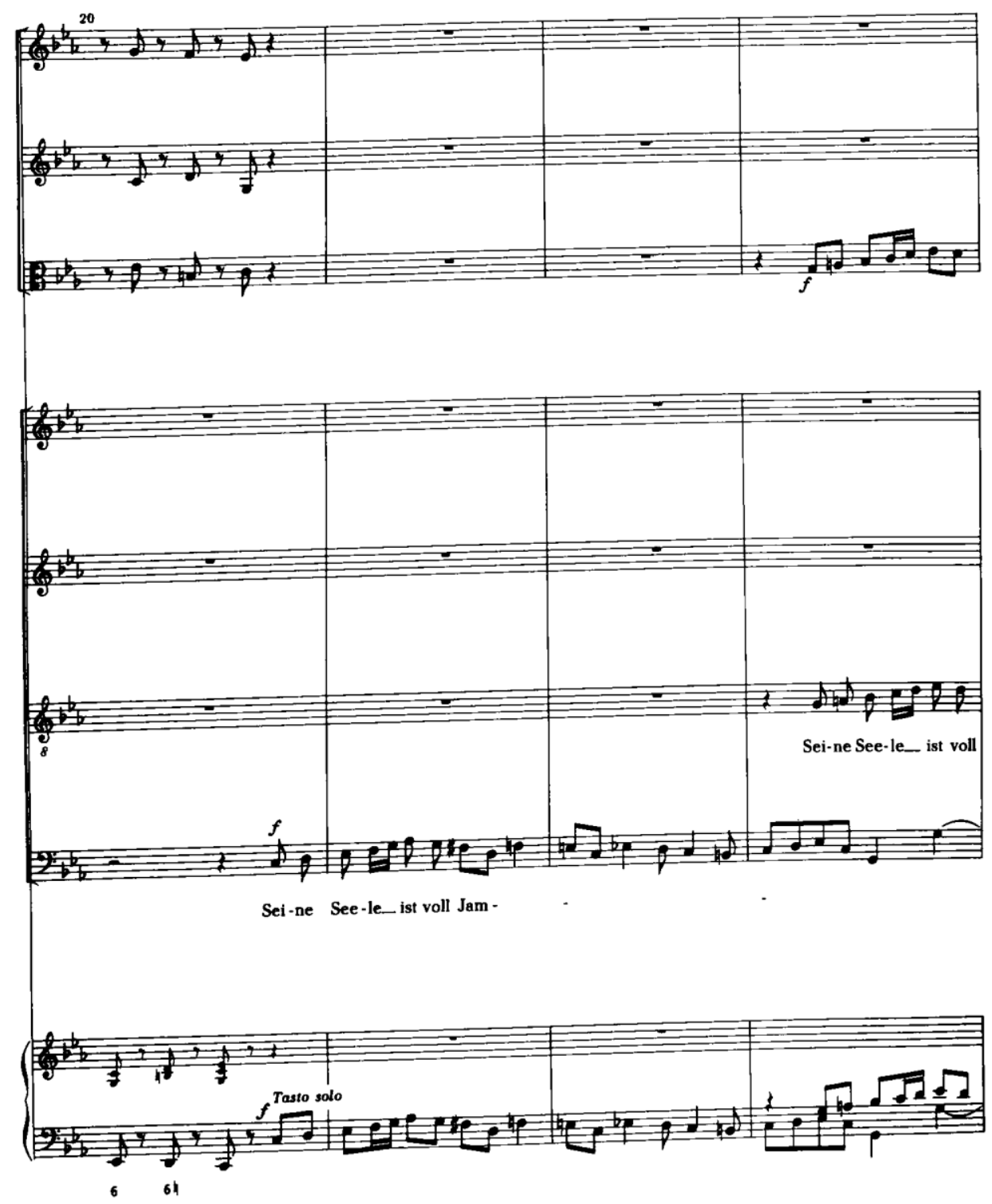




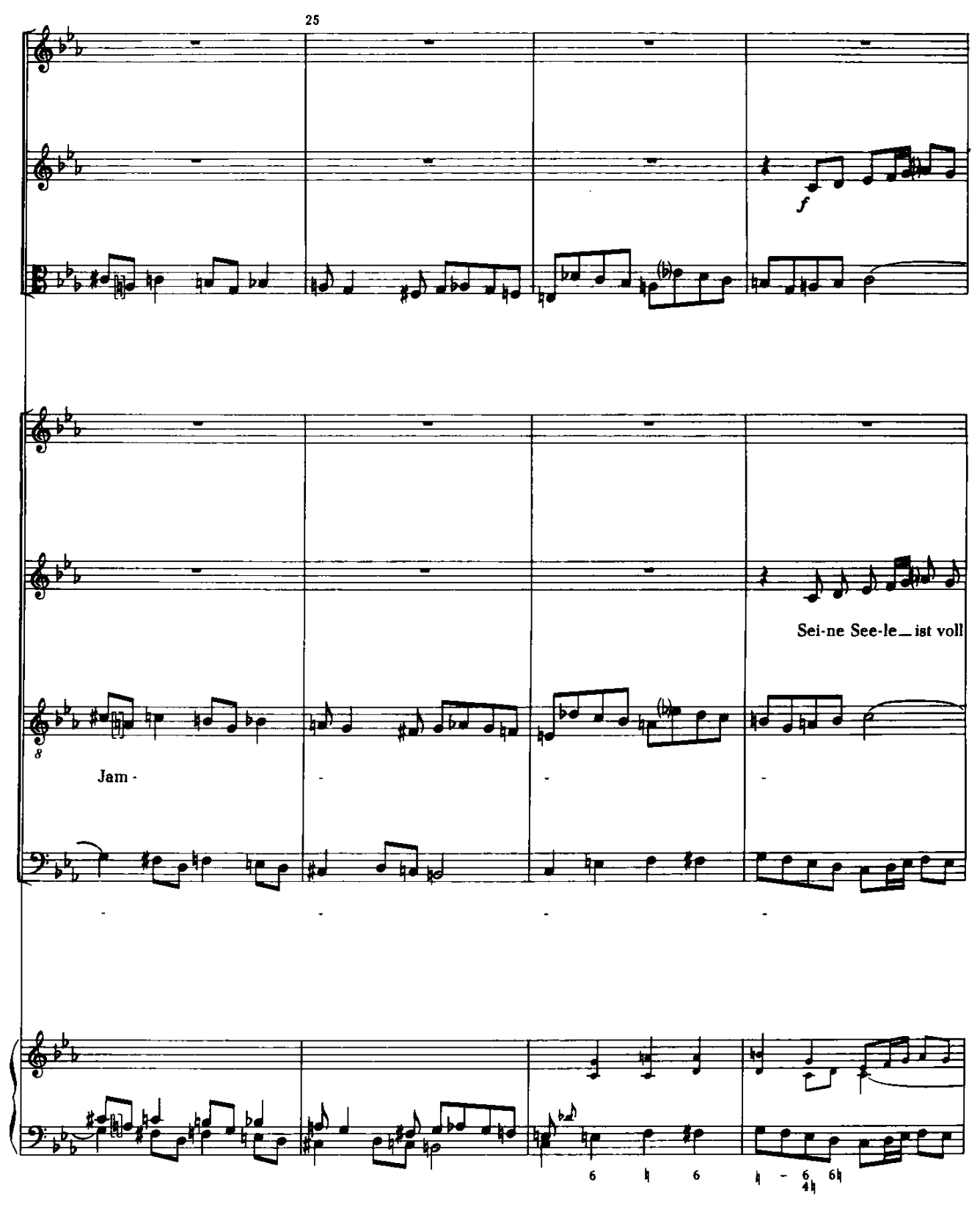




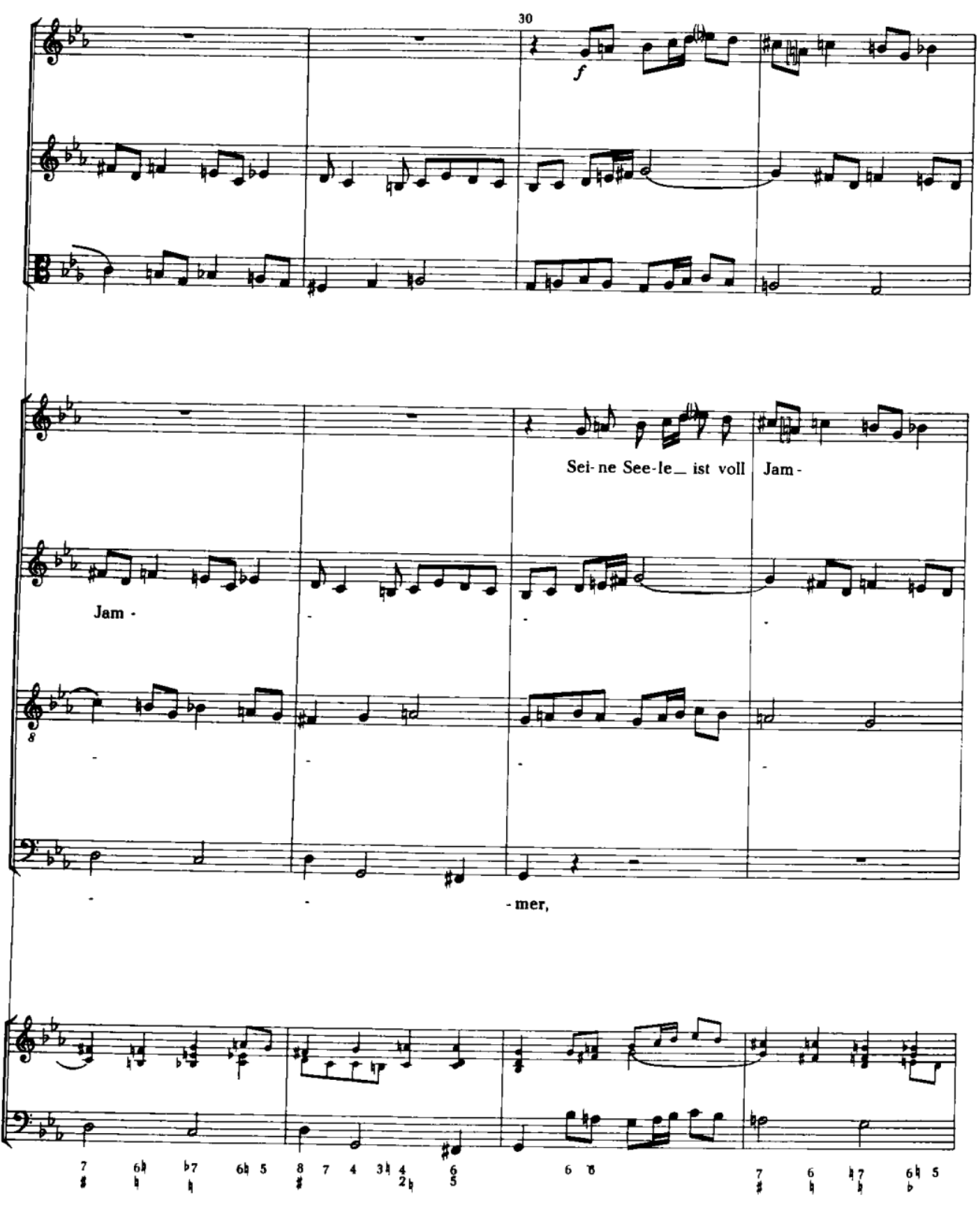




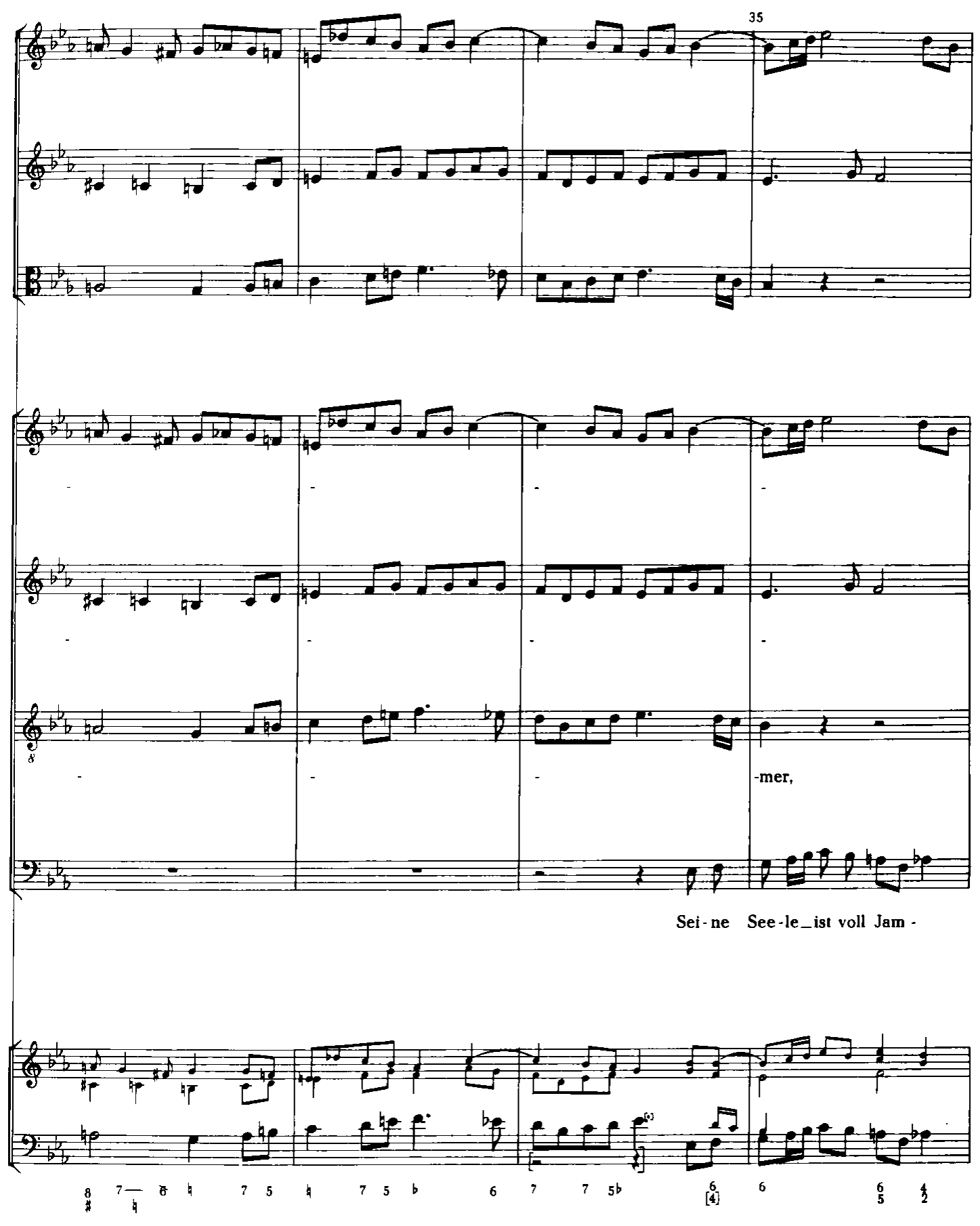




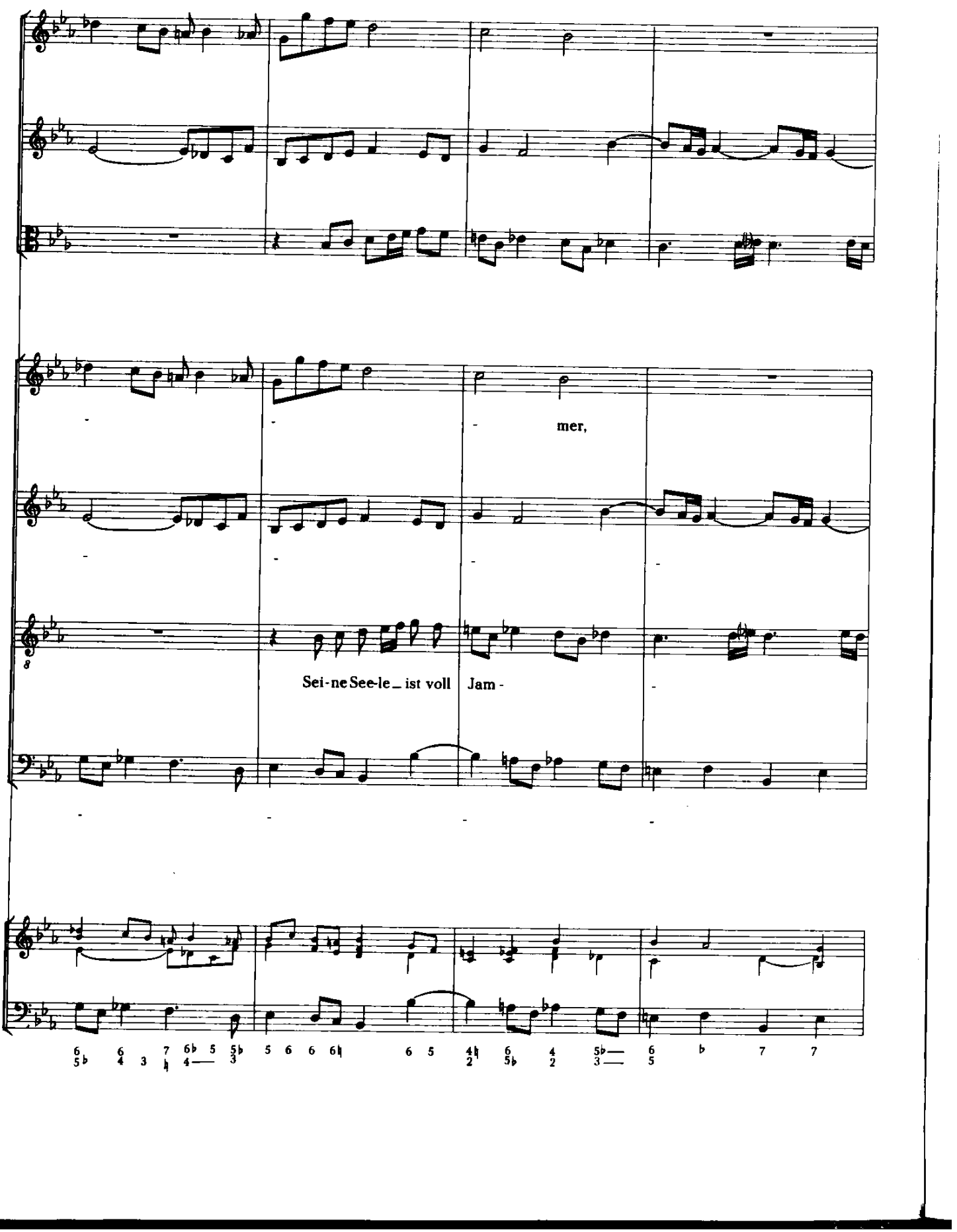




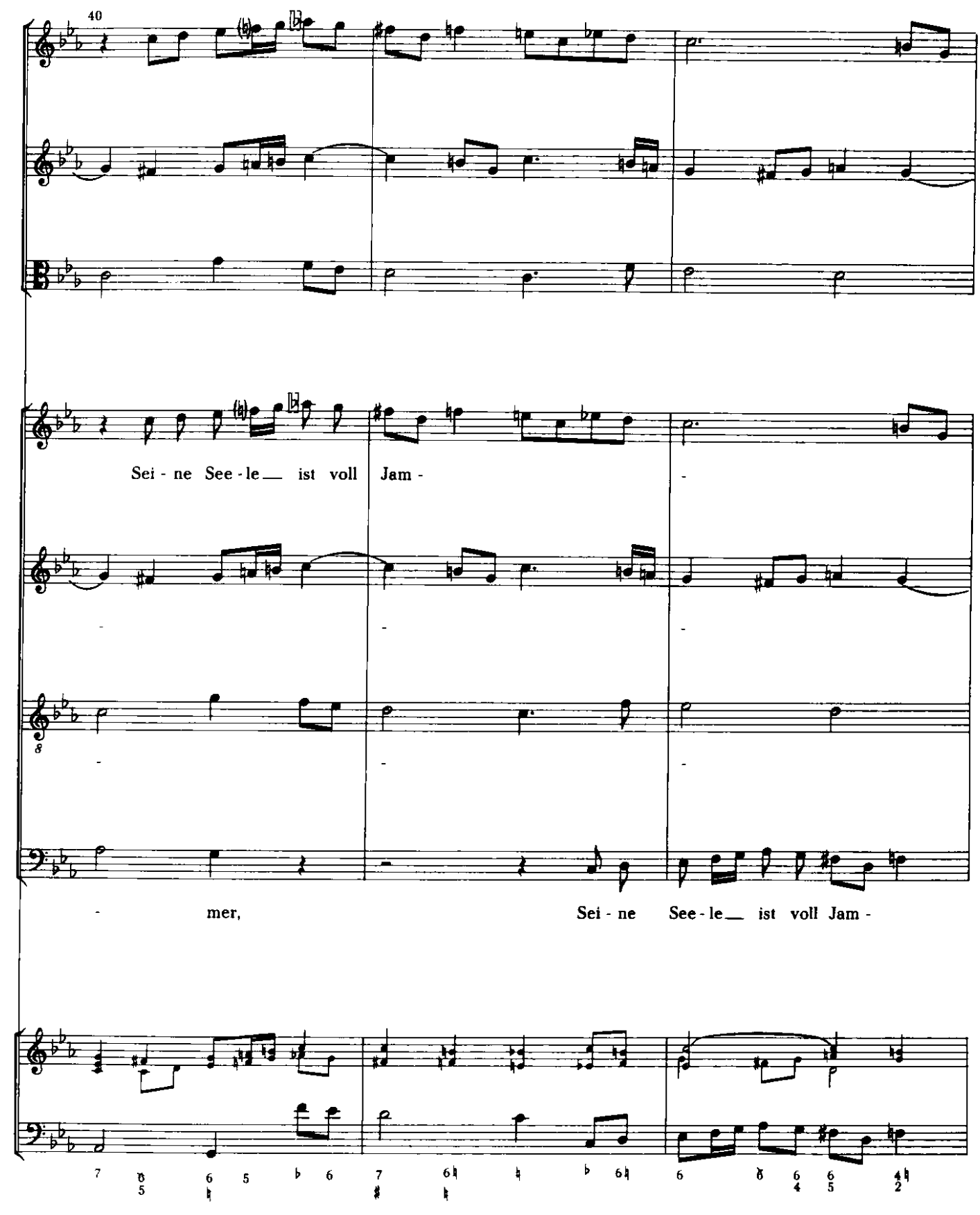




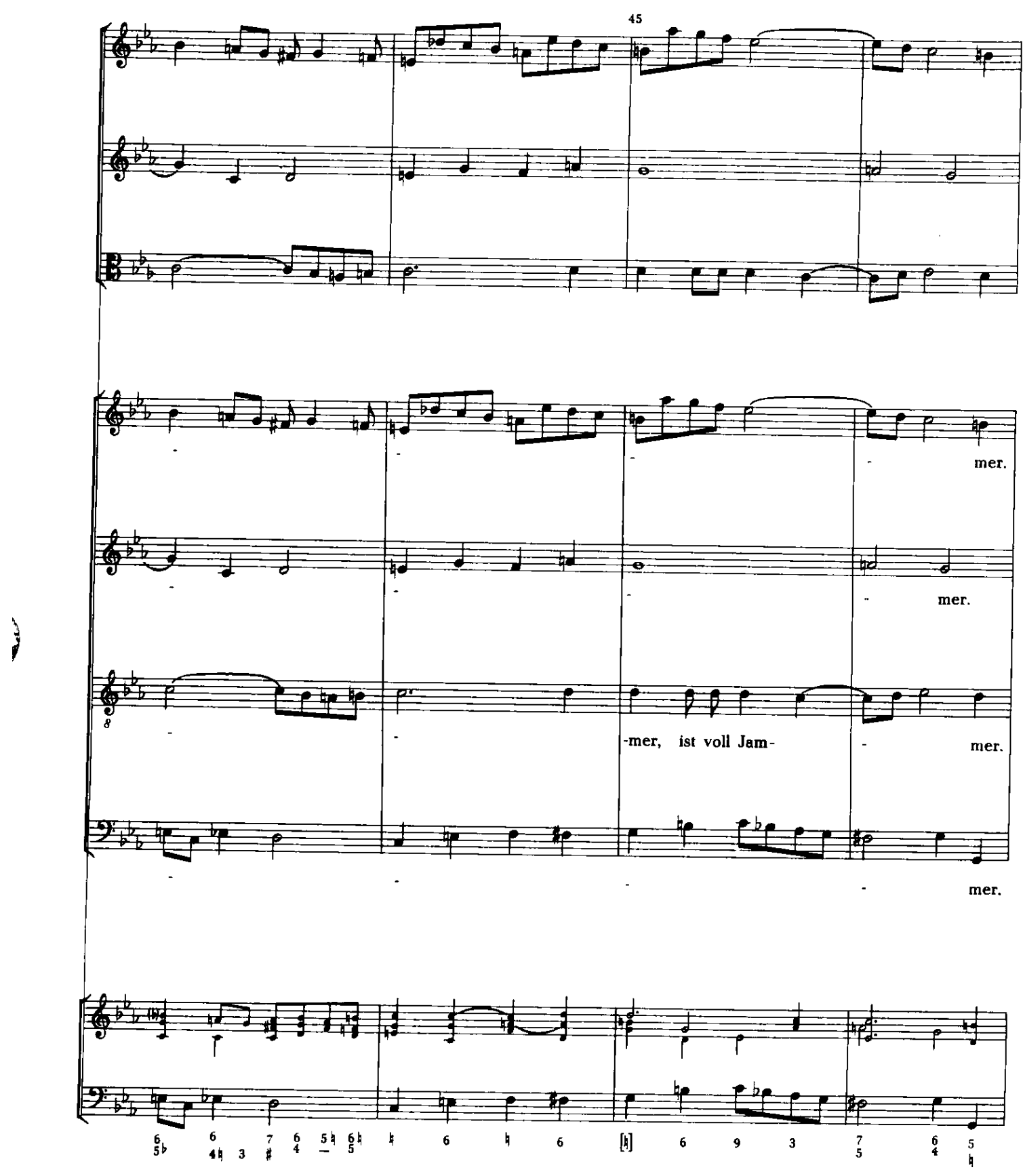




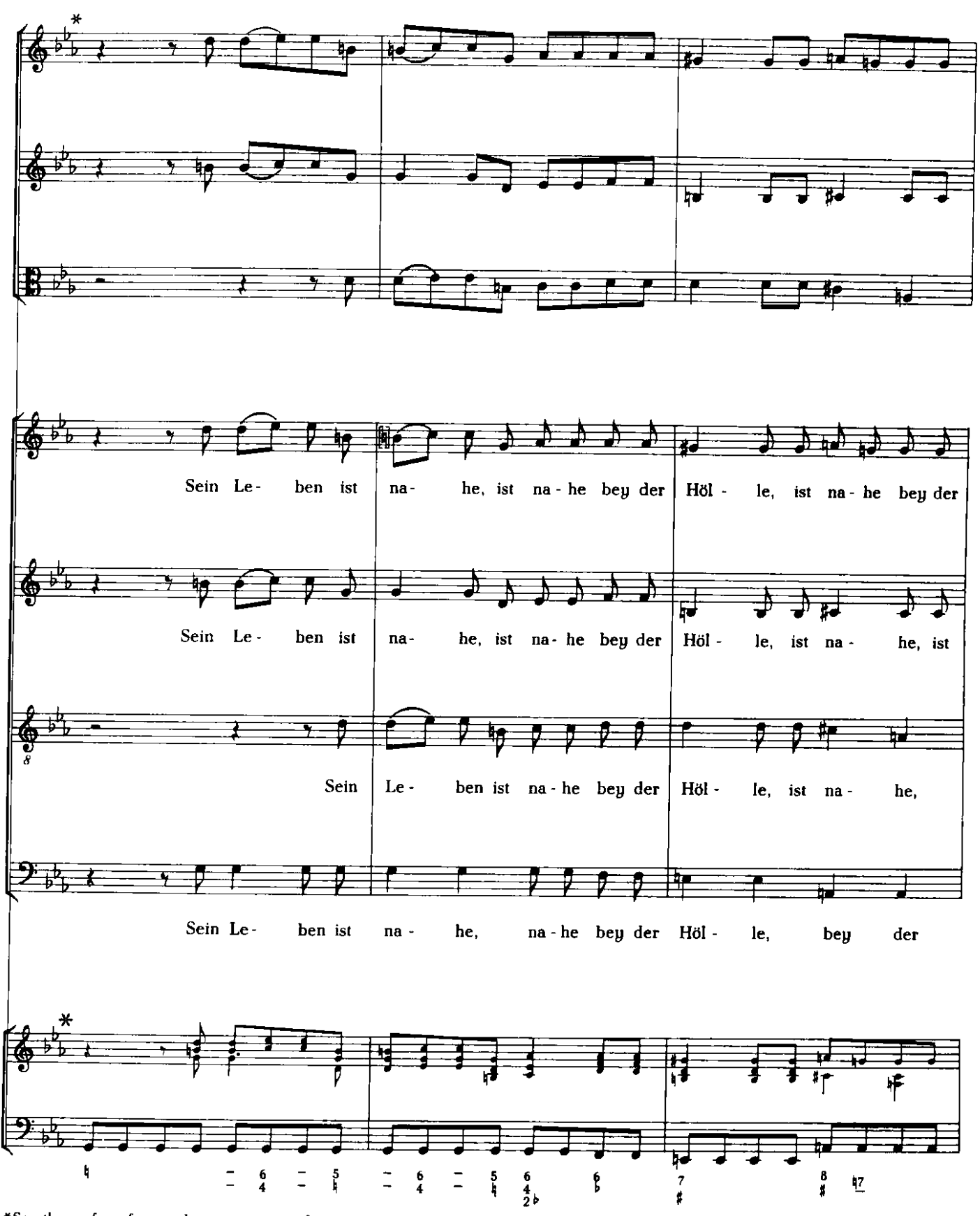

* See the preface for an alternate version of measures 47-51. 


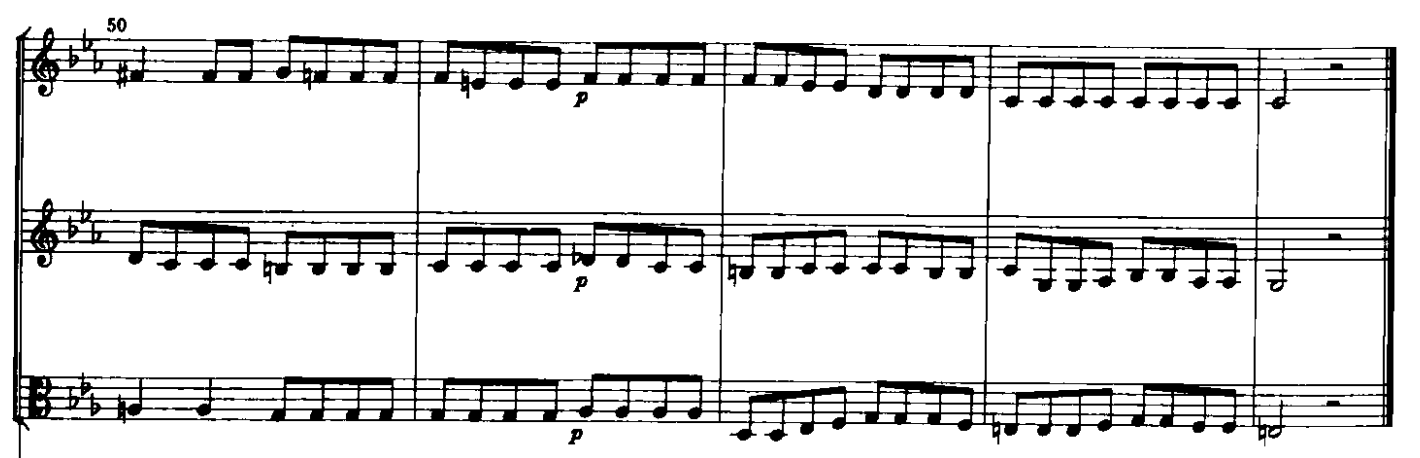

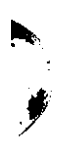

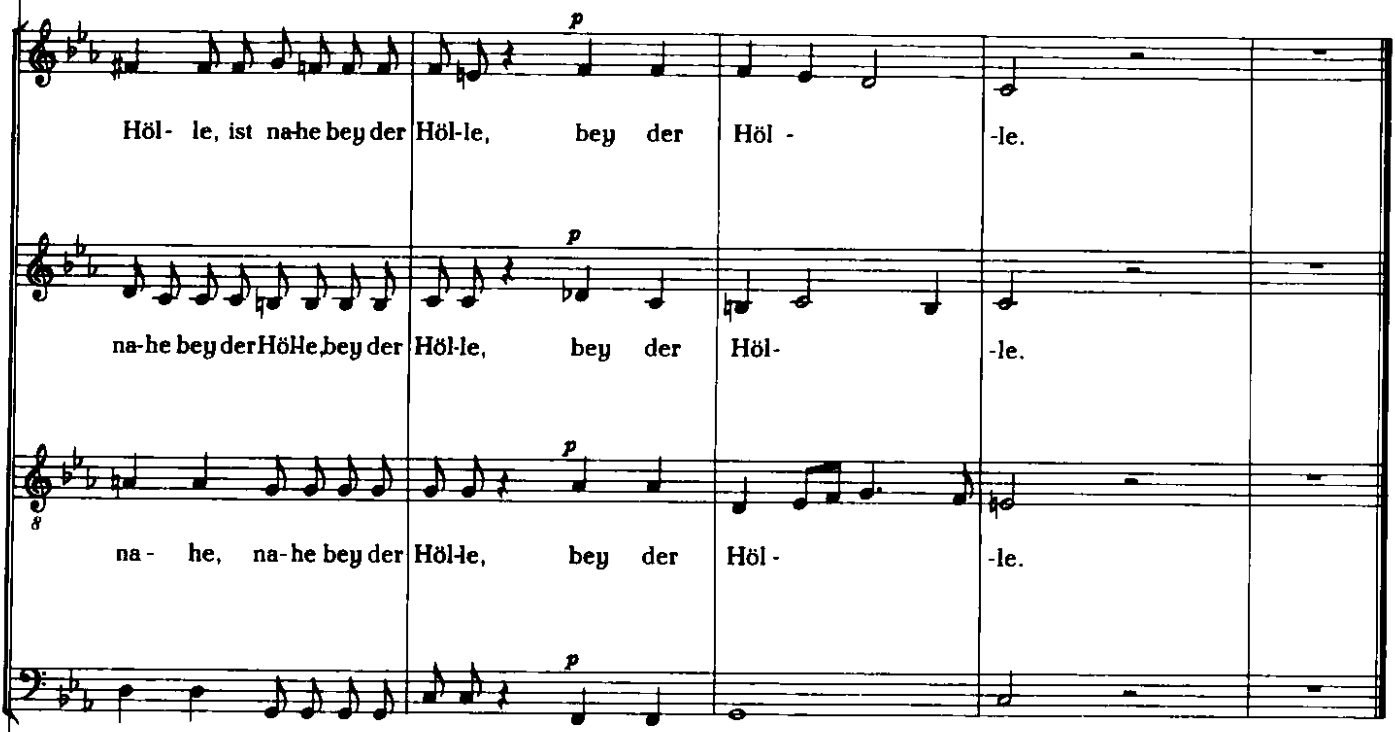

bey der Höl

-le.

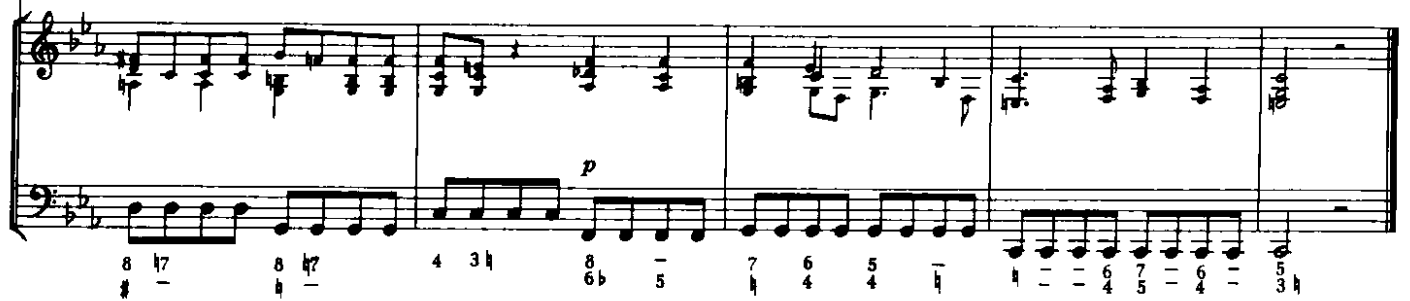


[III] Recit.
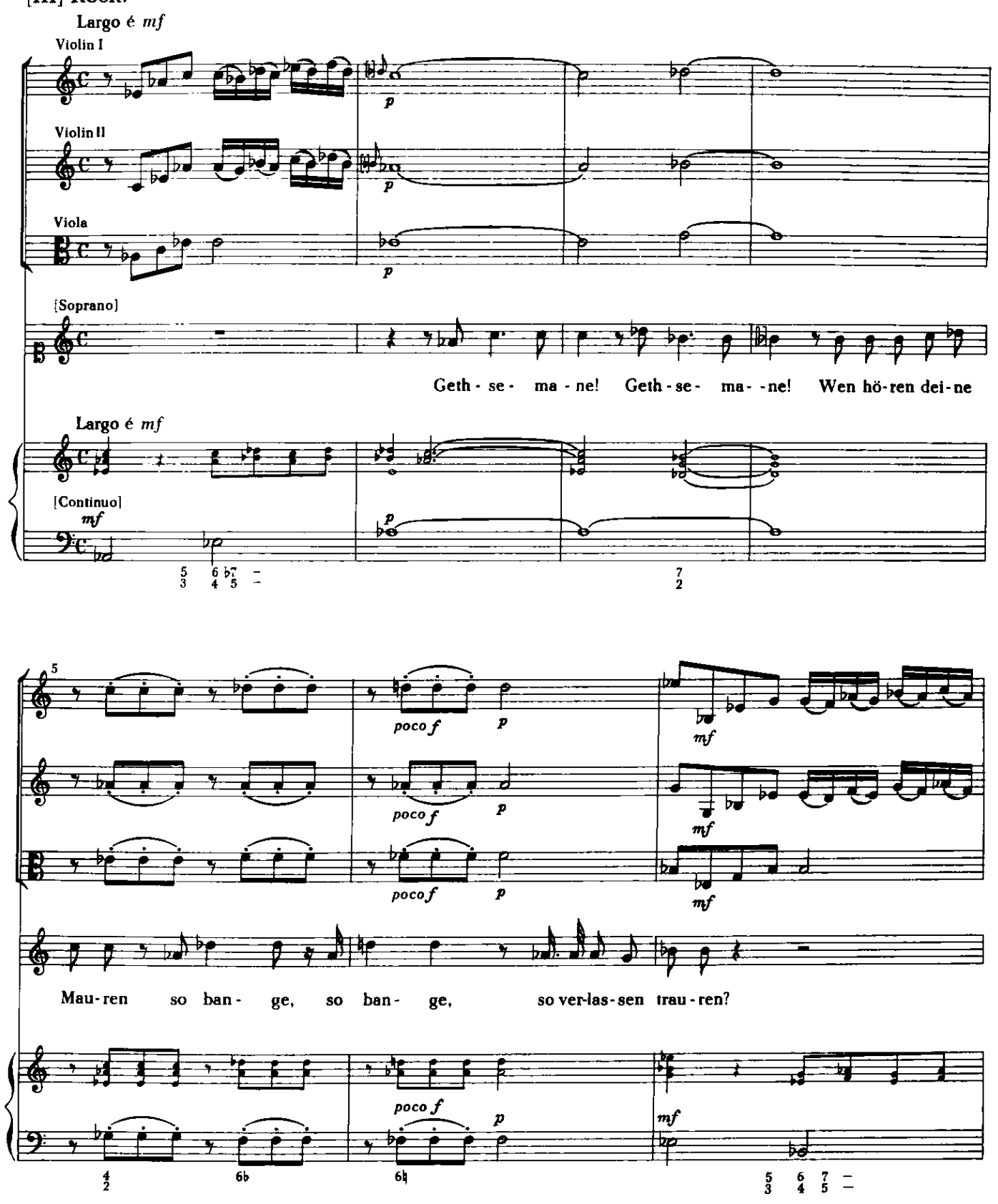


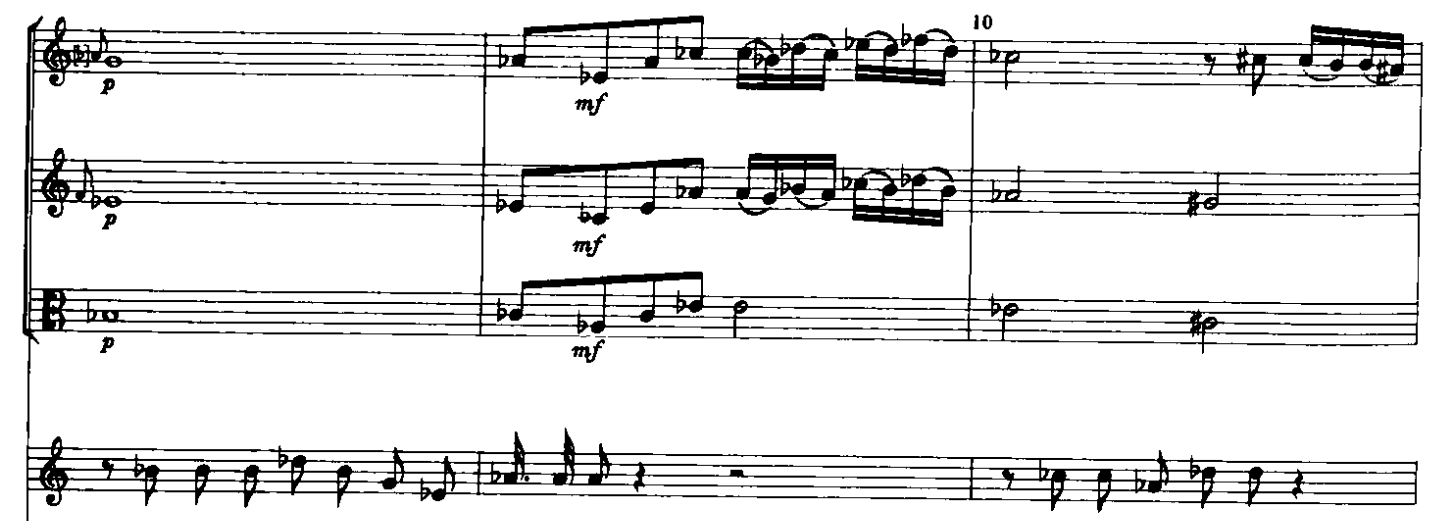

Wer ist der pein-lich lang-sam ster-ben-de?

Ist das mein Je- sus?

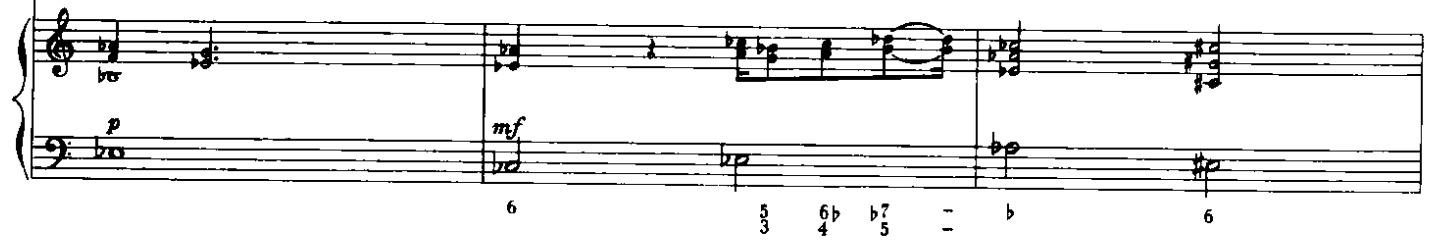

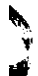

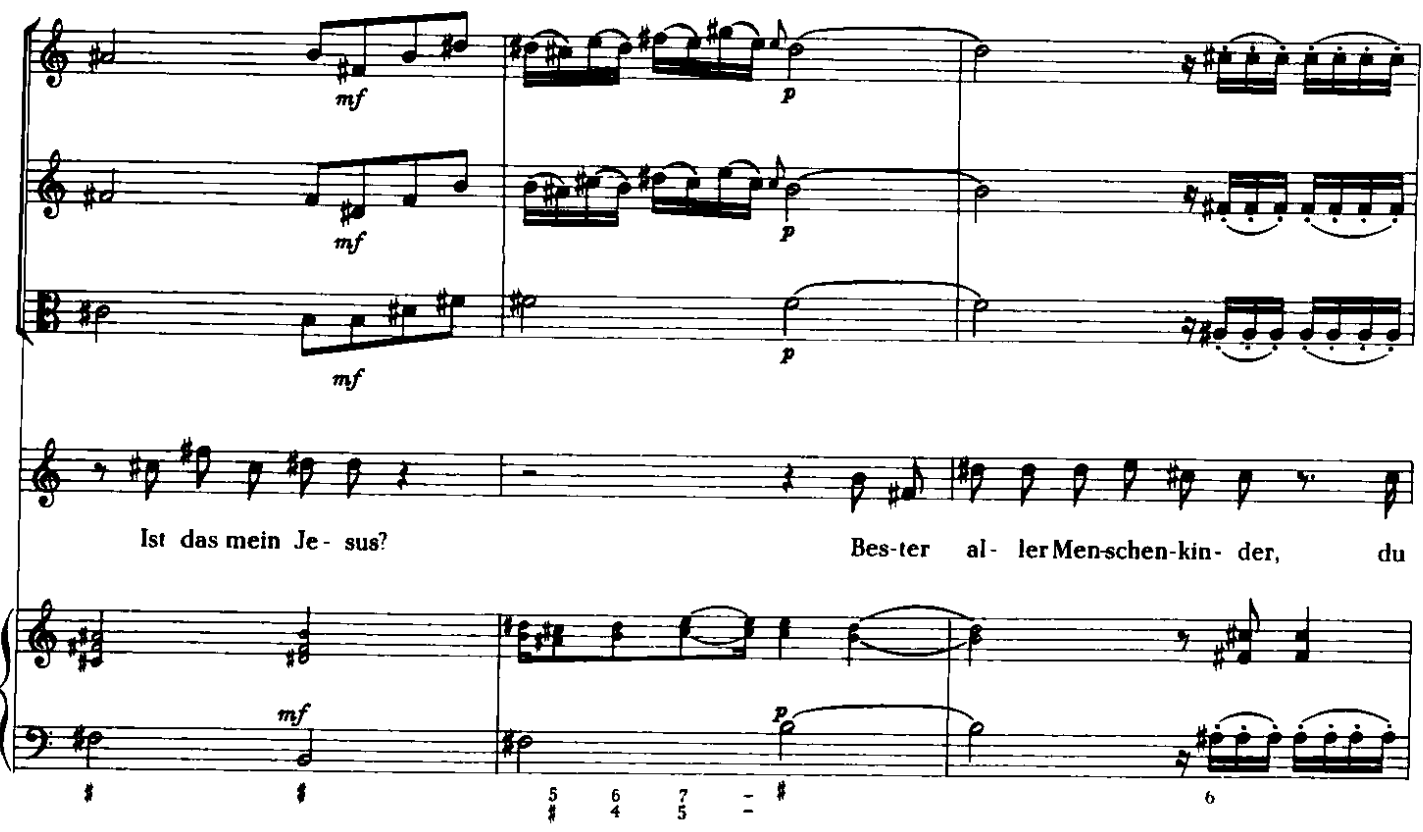



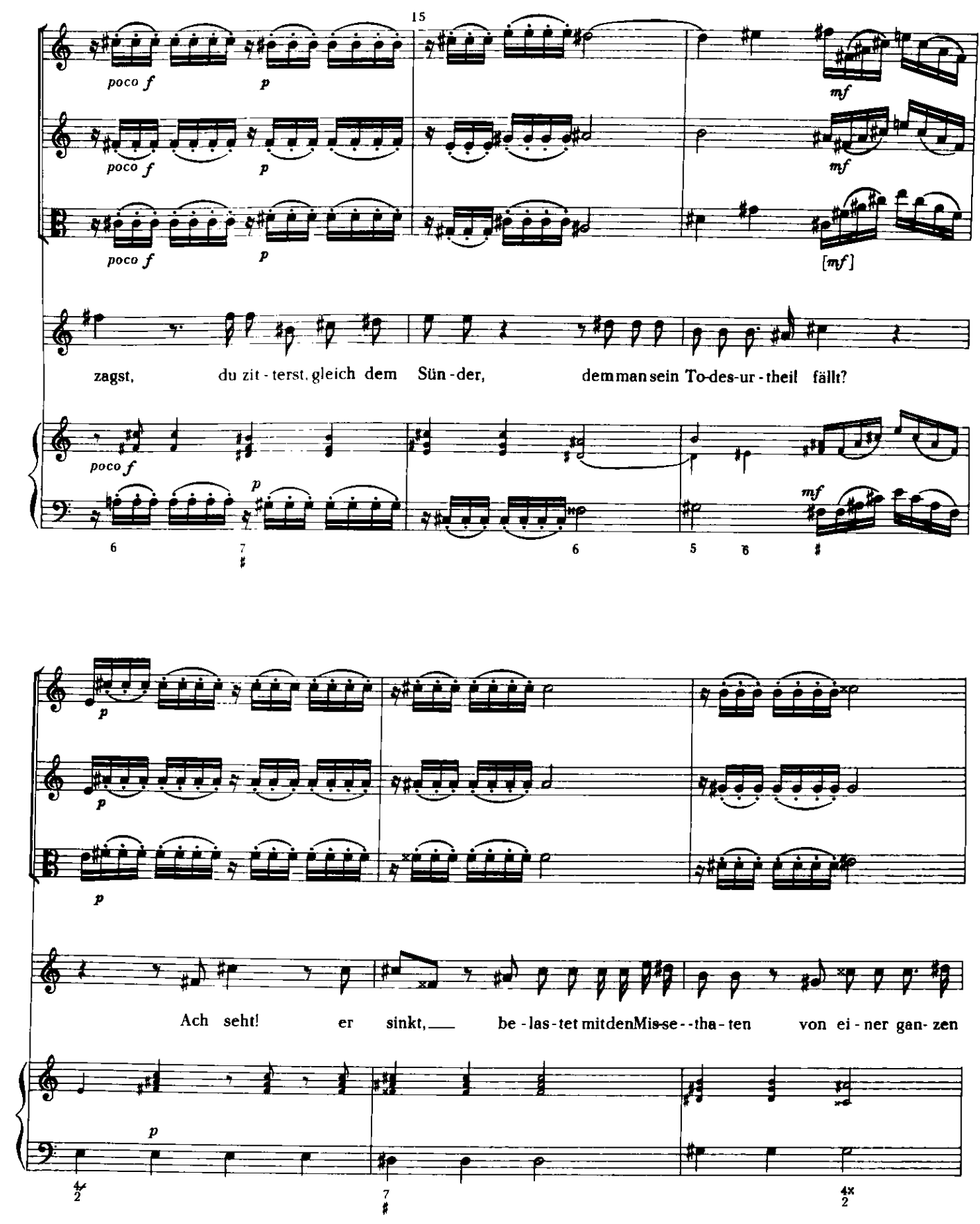

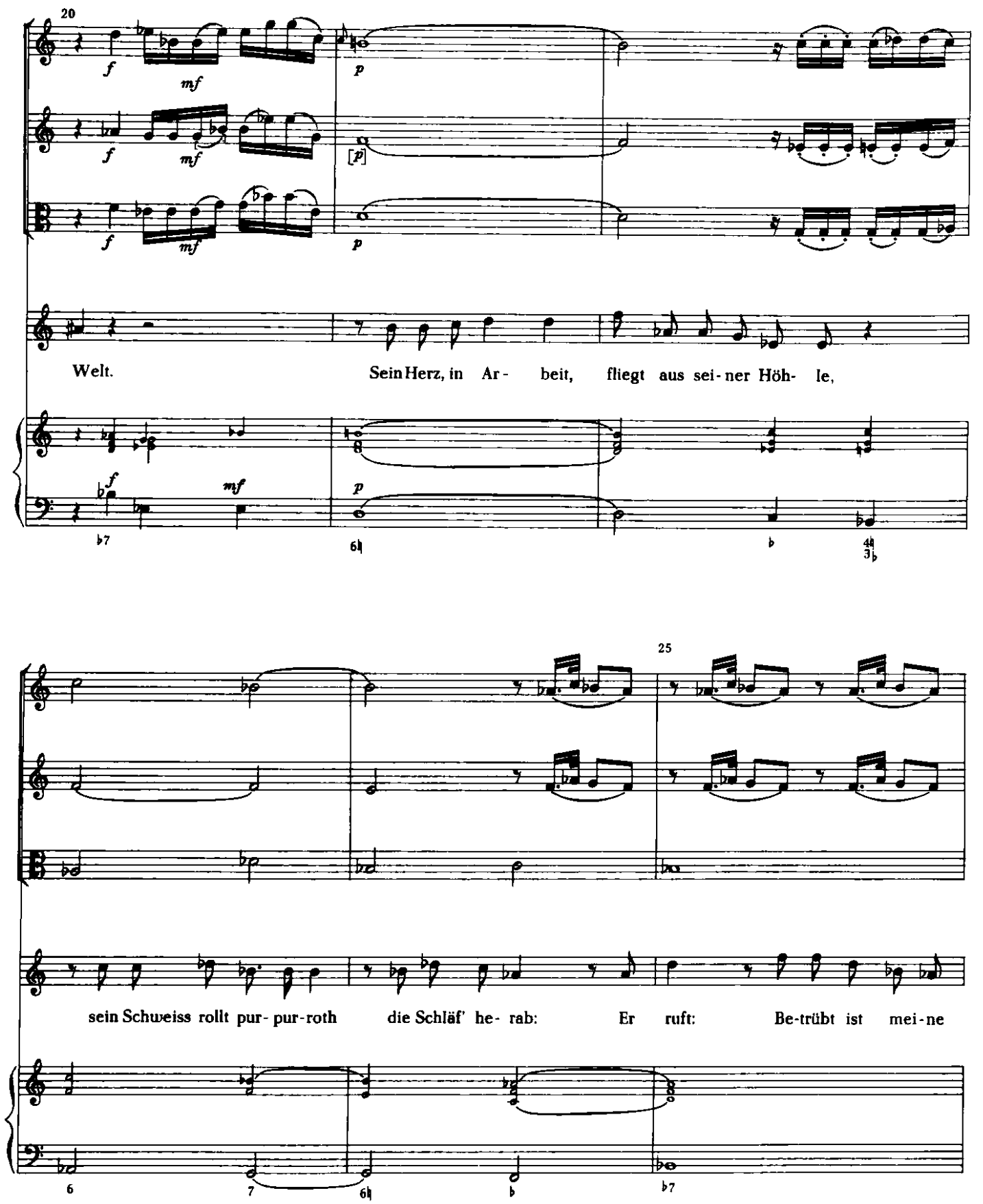


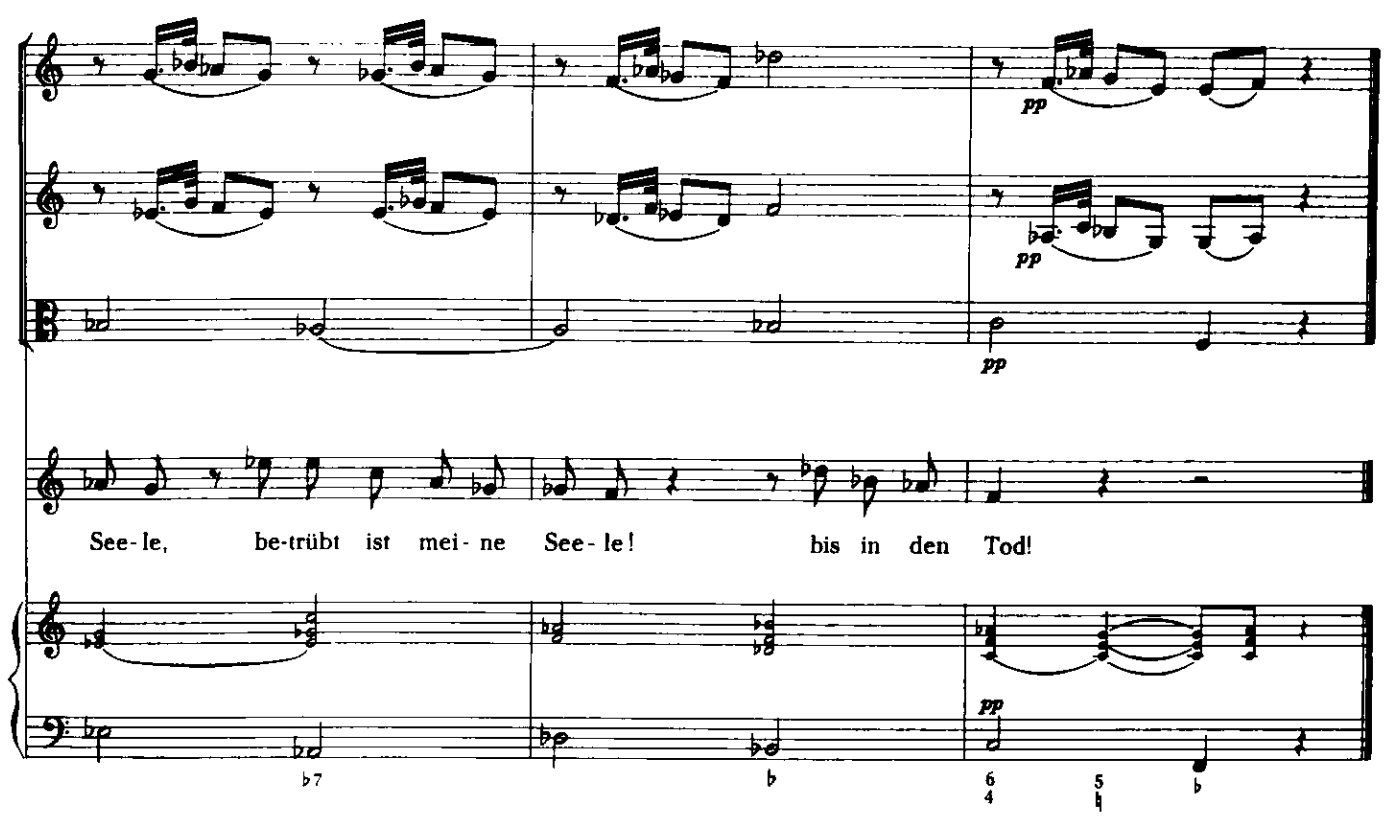

[IV] Aria
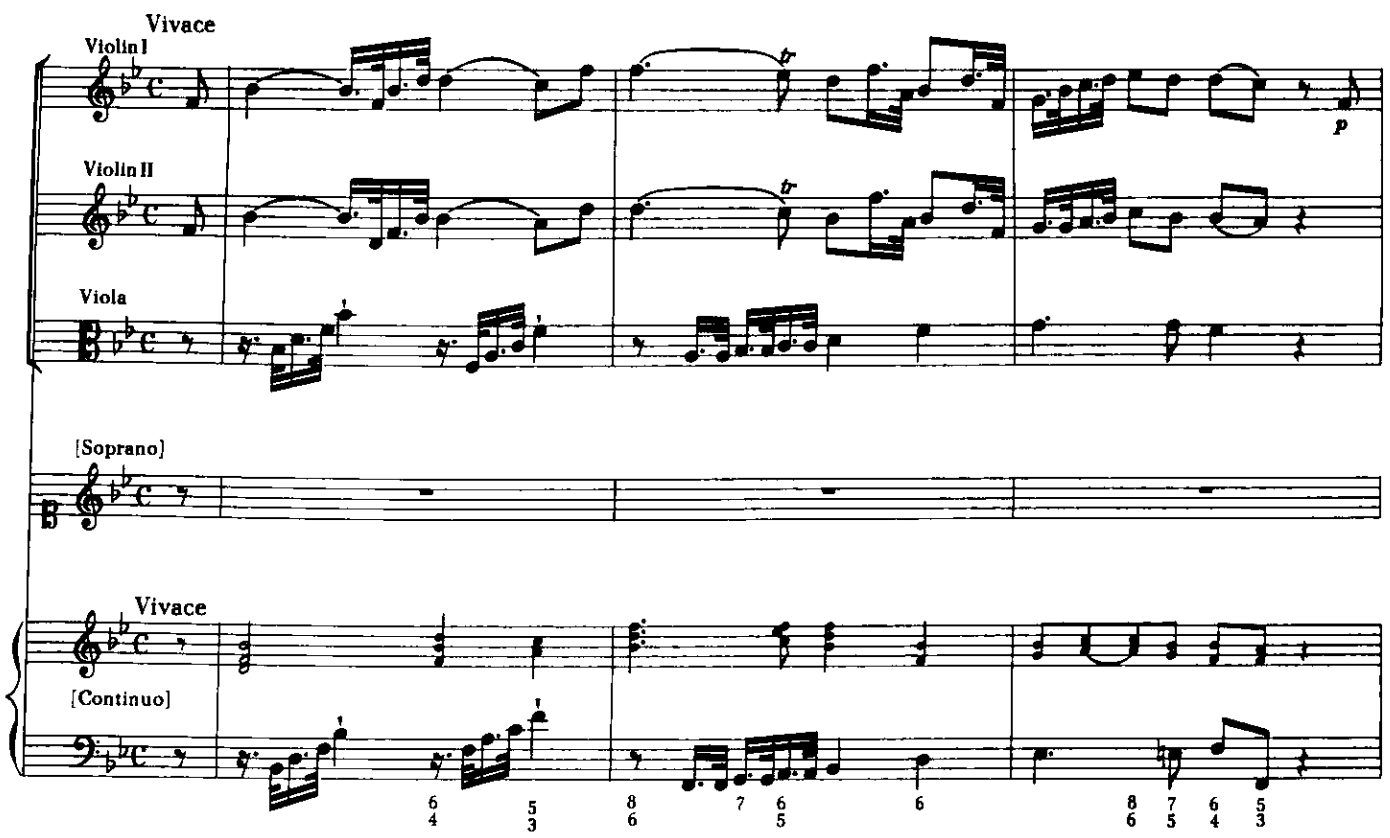
Example 3: Graun Der Tod Jesu No. 6 Recitative

[VI] Recit.
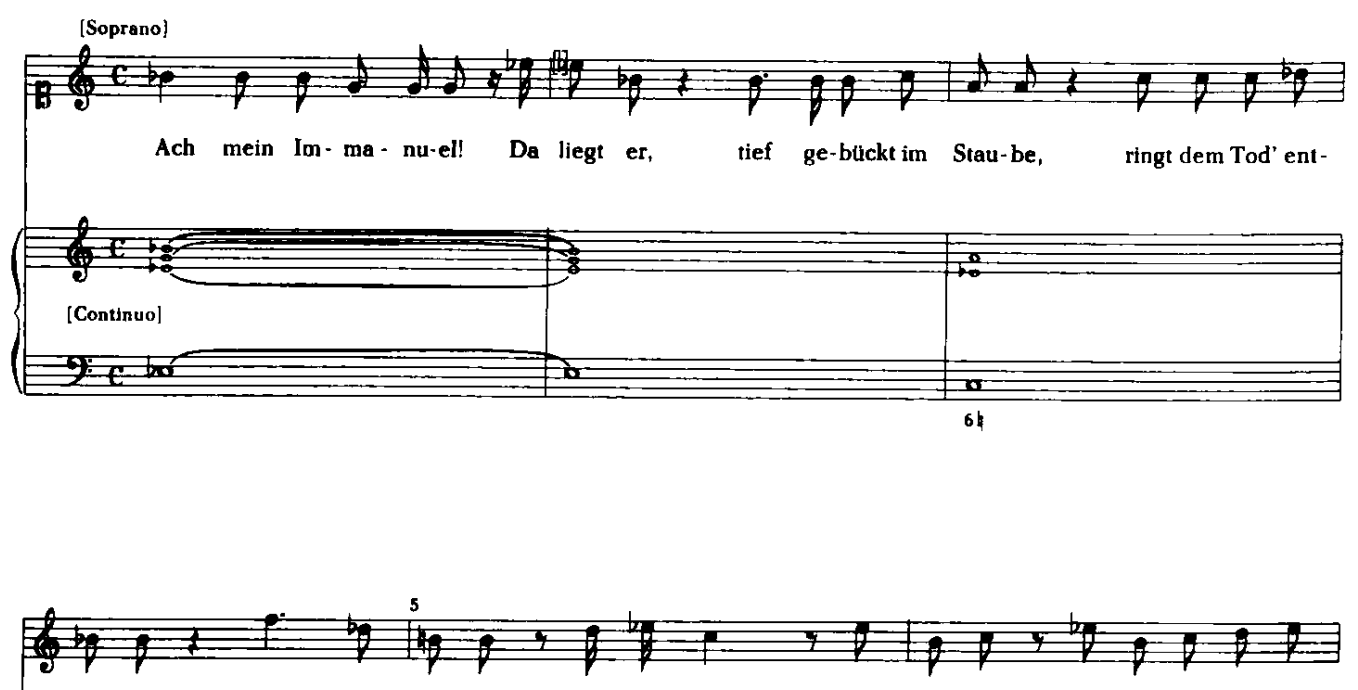
ge-gen, blickt gen Him-mel, jam-mert laut: Lass, Va-ter, lass, Va-ter, die-se
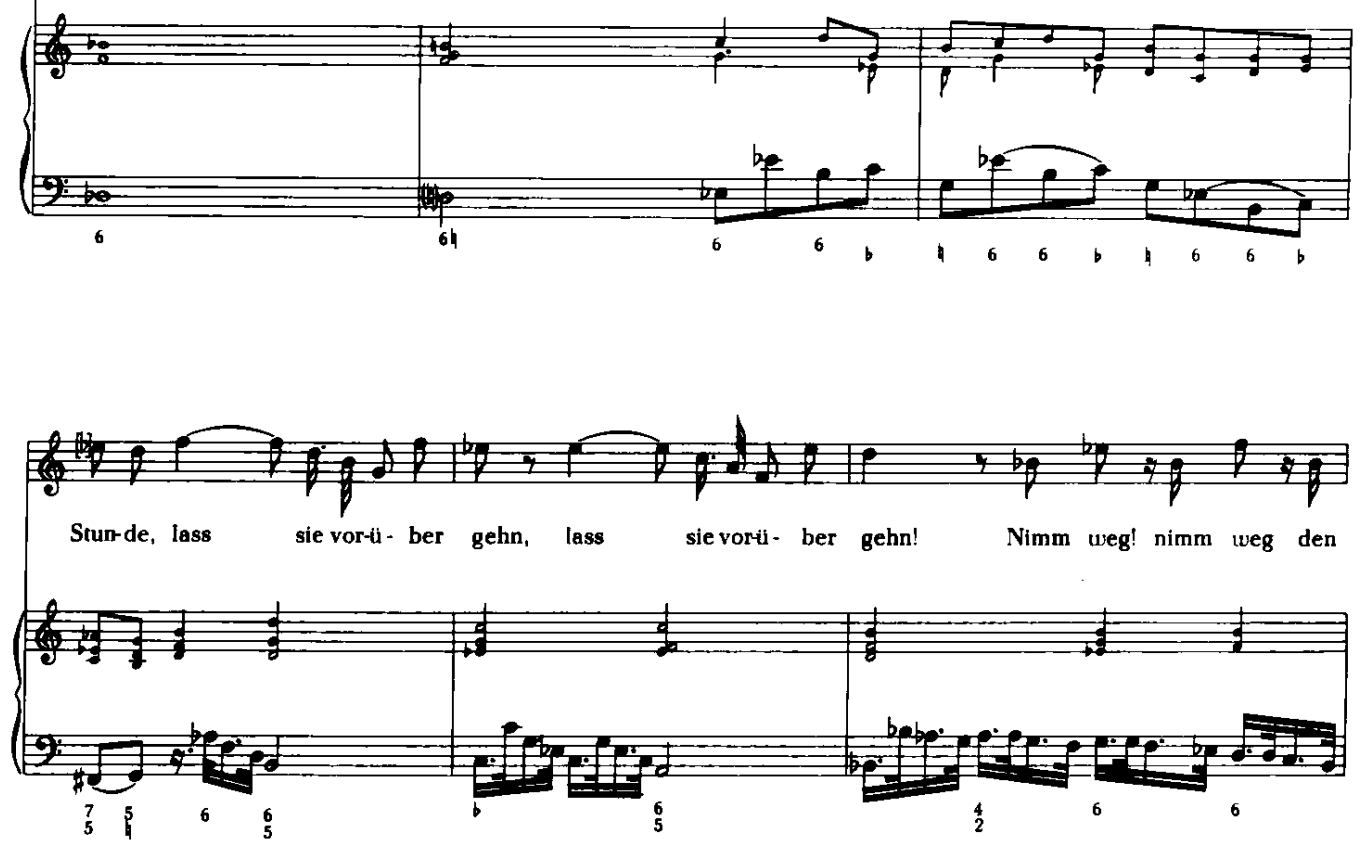

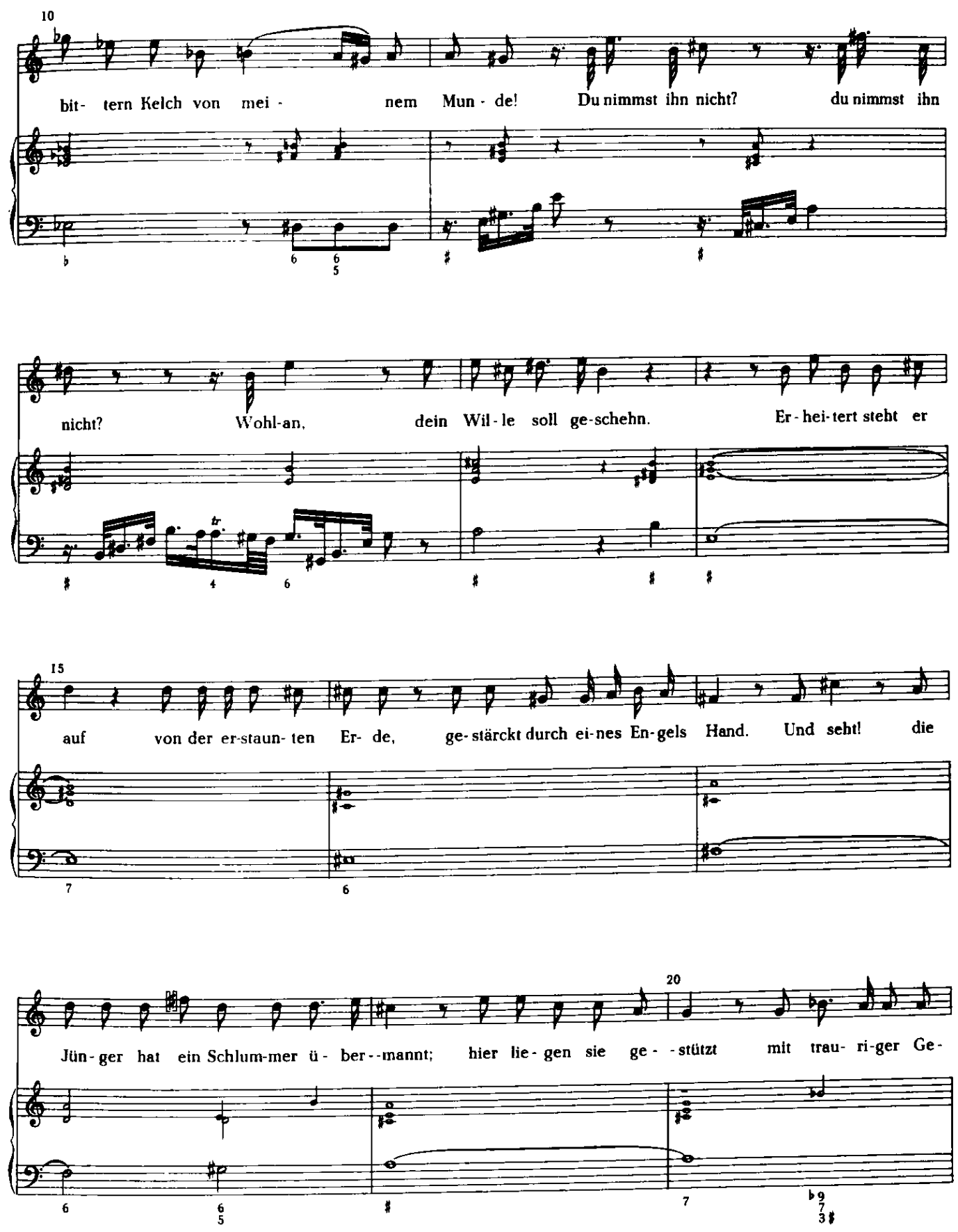

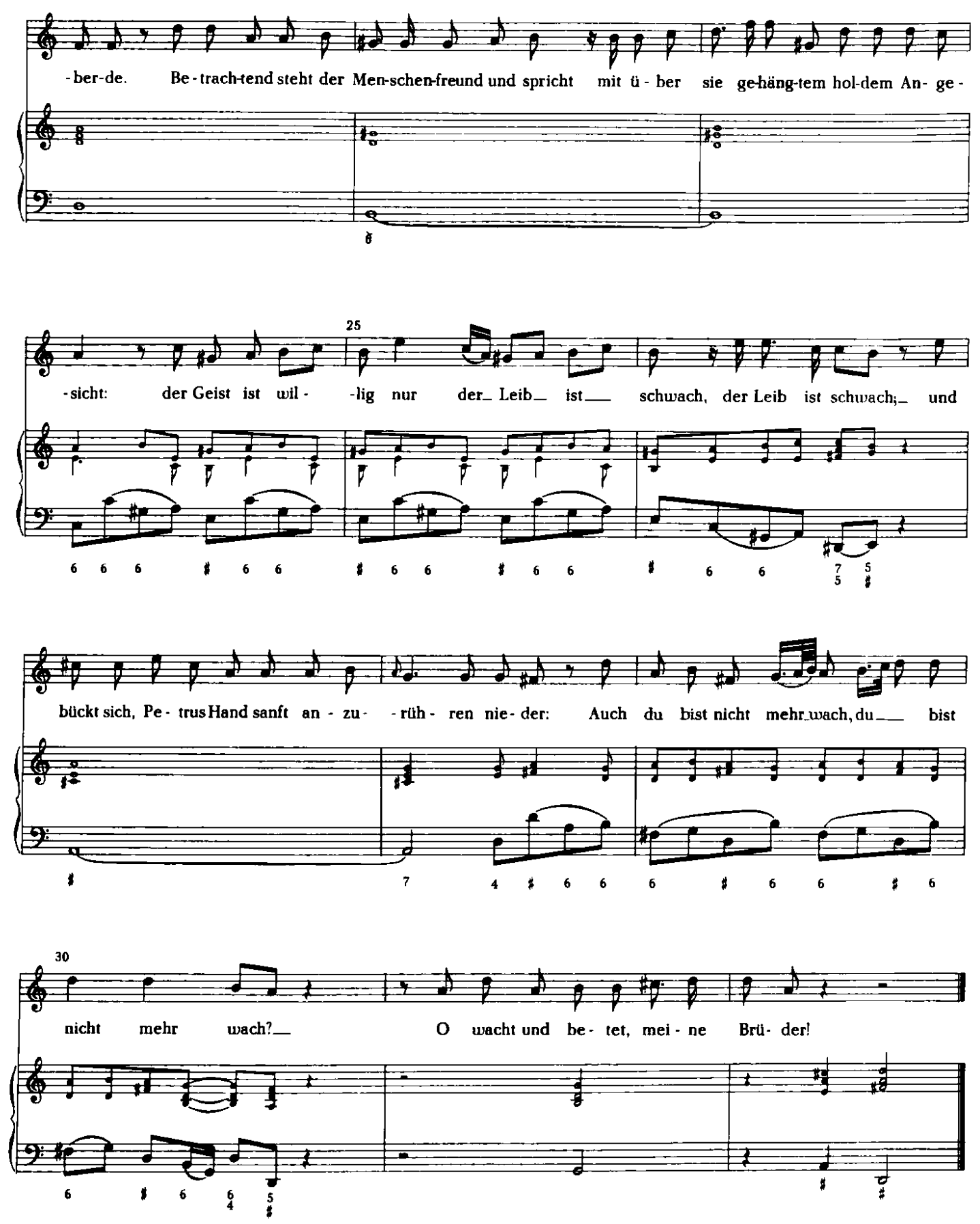
Example 4: Beethoven Christus am Olberge Orchestral Introduction

\section{Christus am Ölberge}

Oratorium

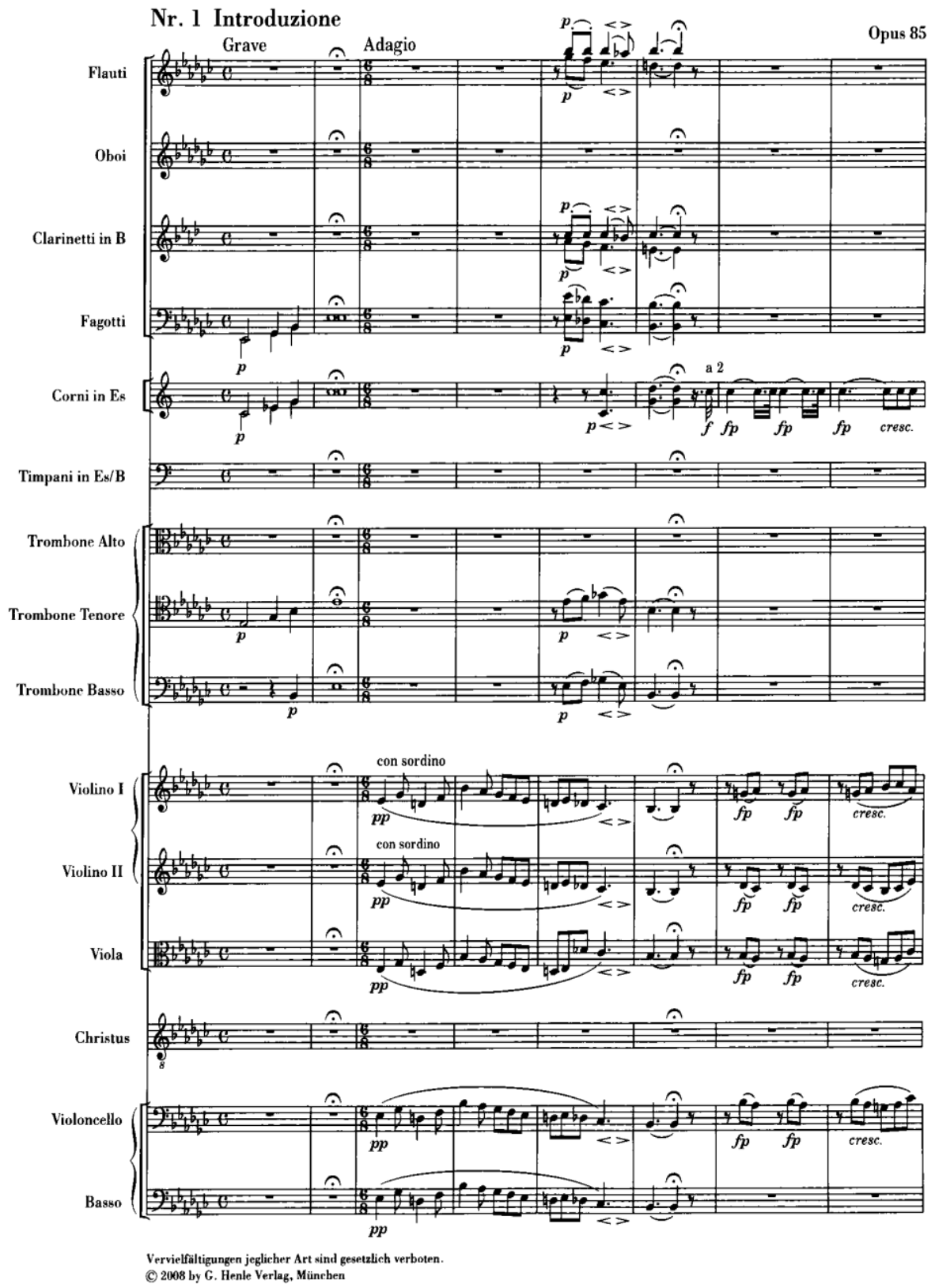



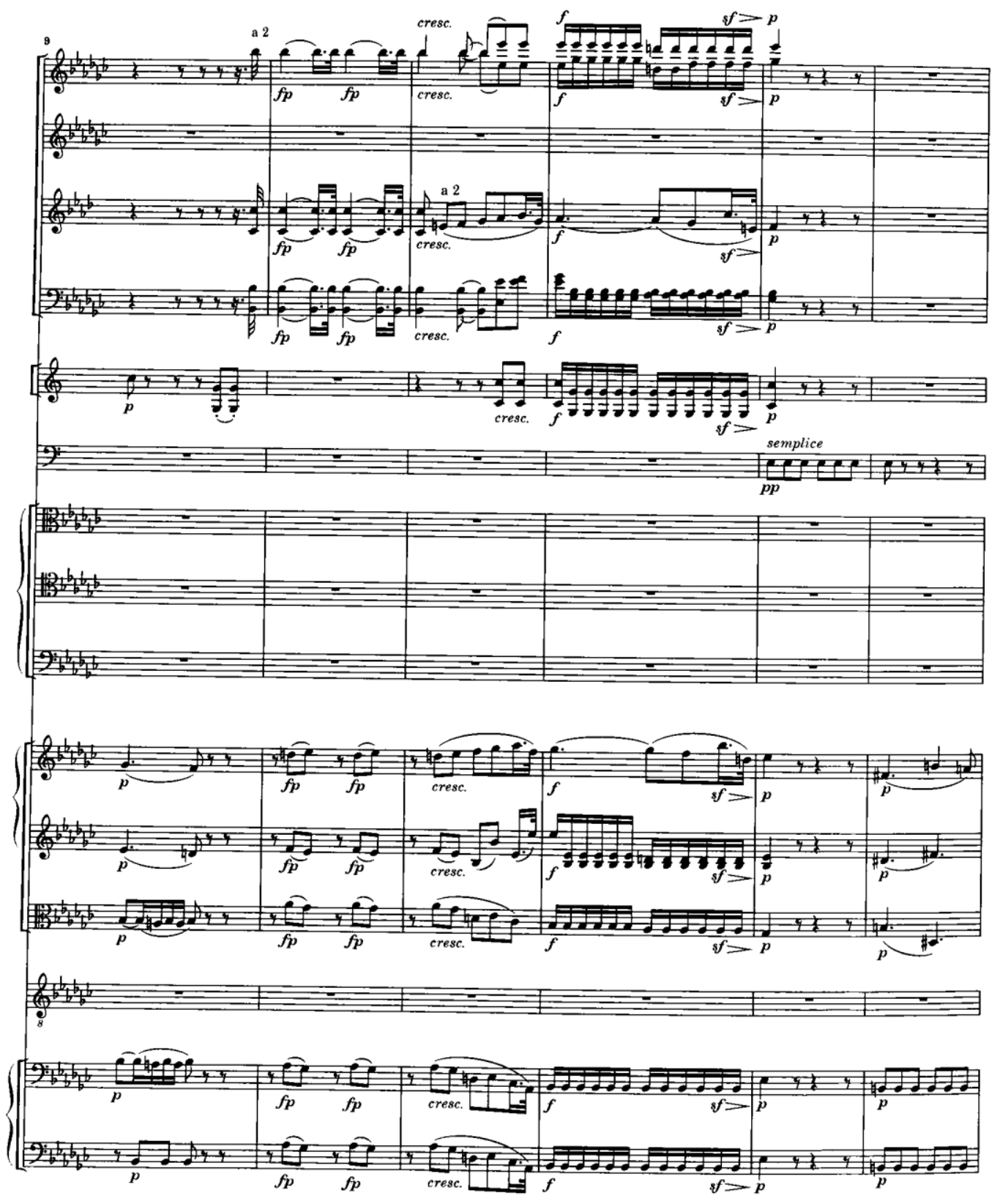

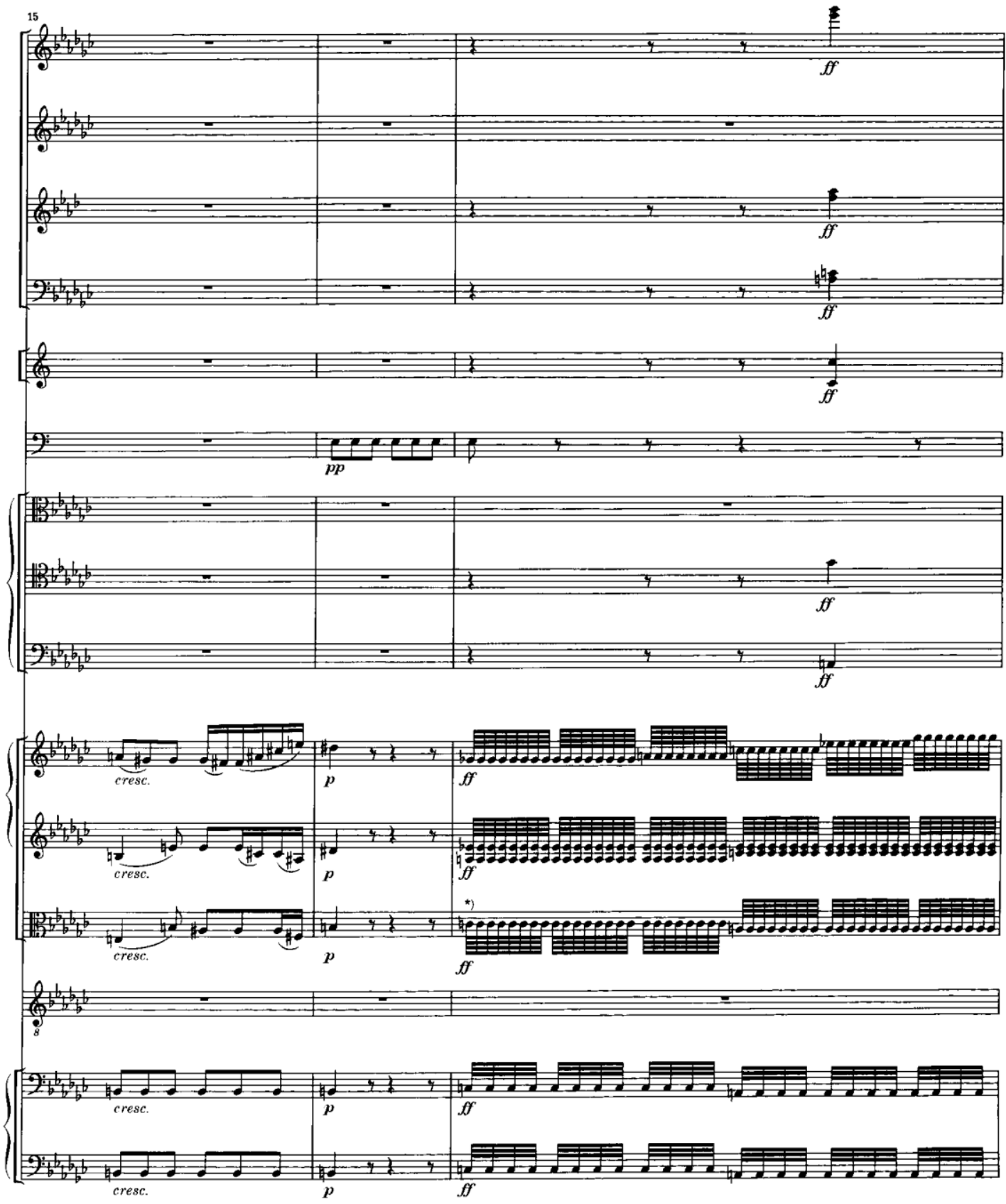

*) In $A_{2}$ rhythmisch wie $\mathrm{V} / / \mathrm{Cl}$; sirhe Kritischer Bericht, Lesartenverzeichnis. 


\section{4}
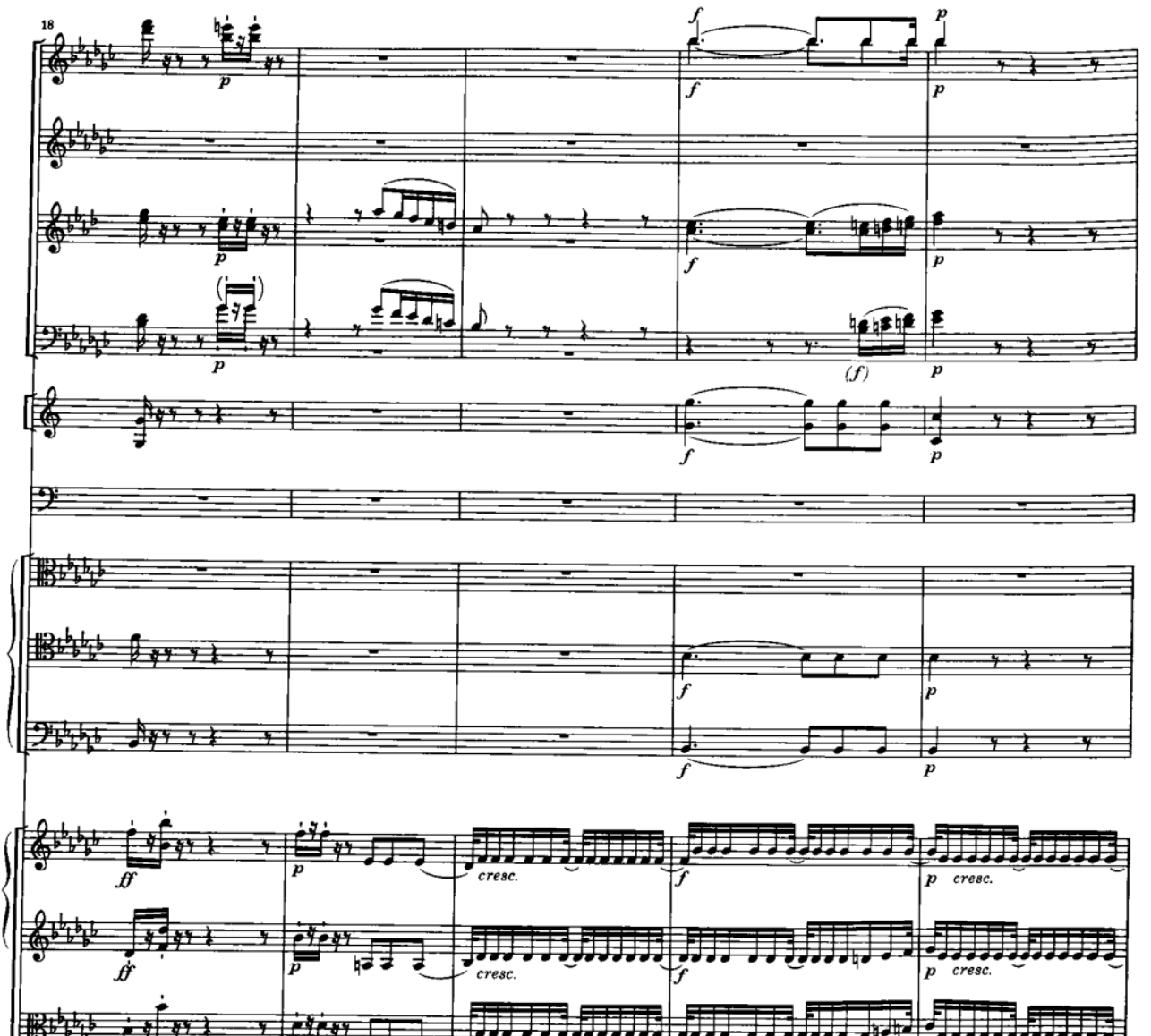

(5)

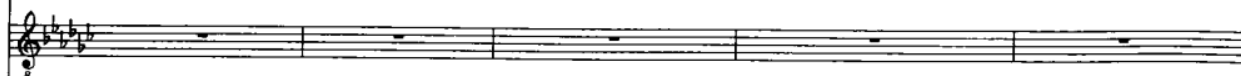
8

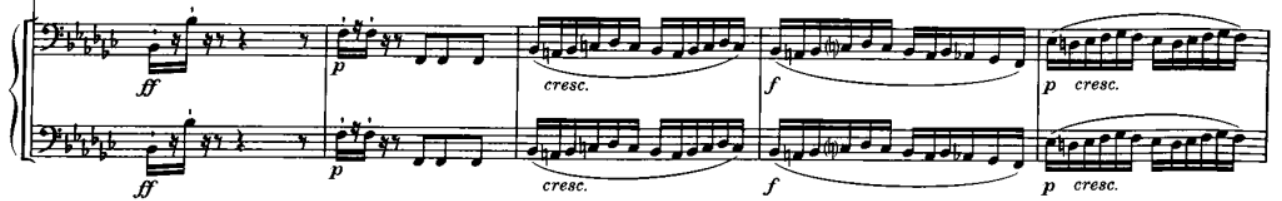



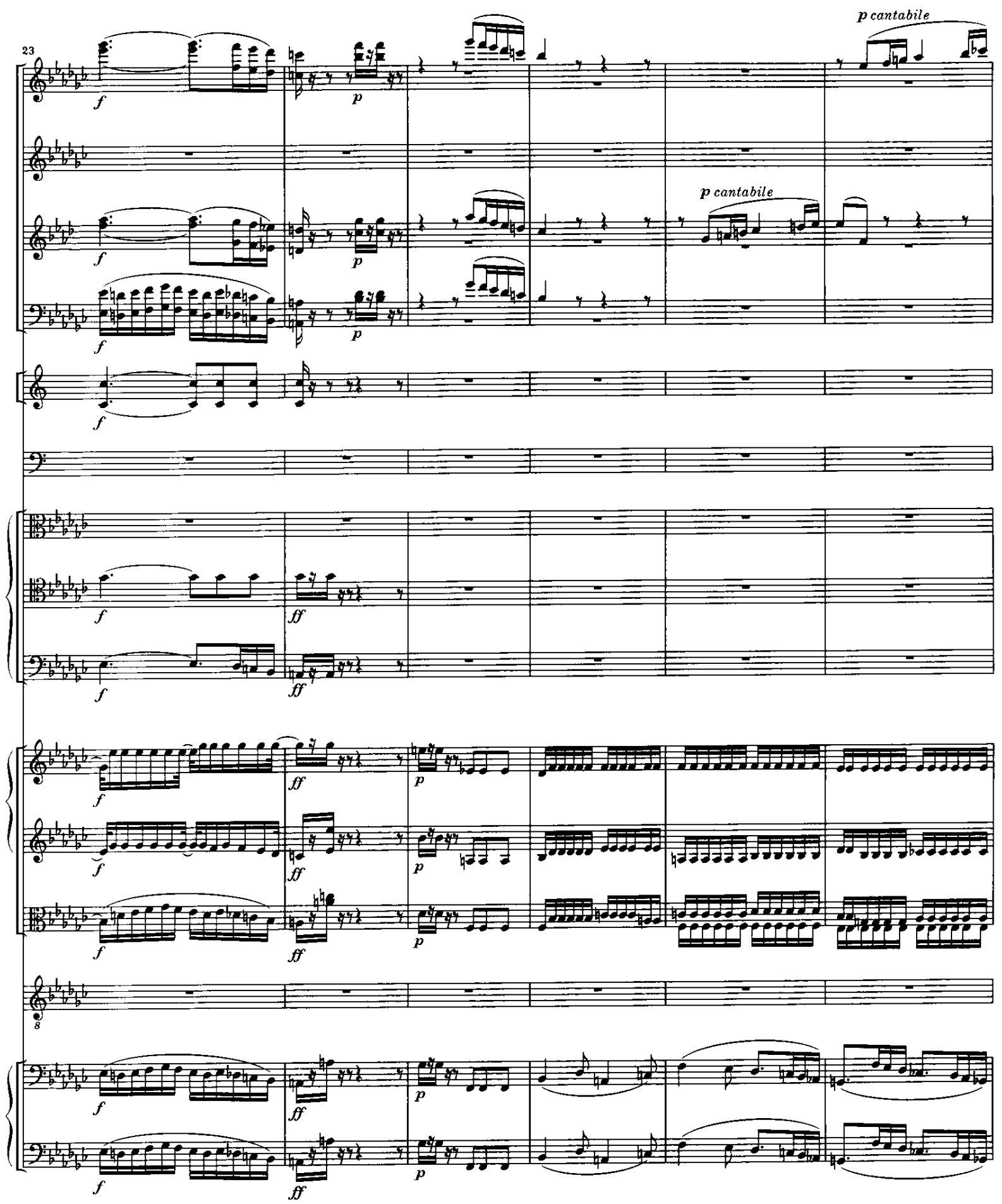


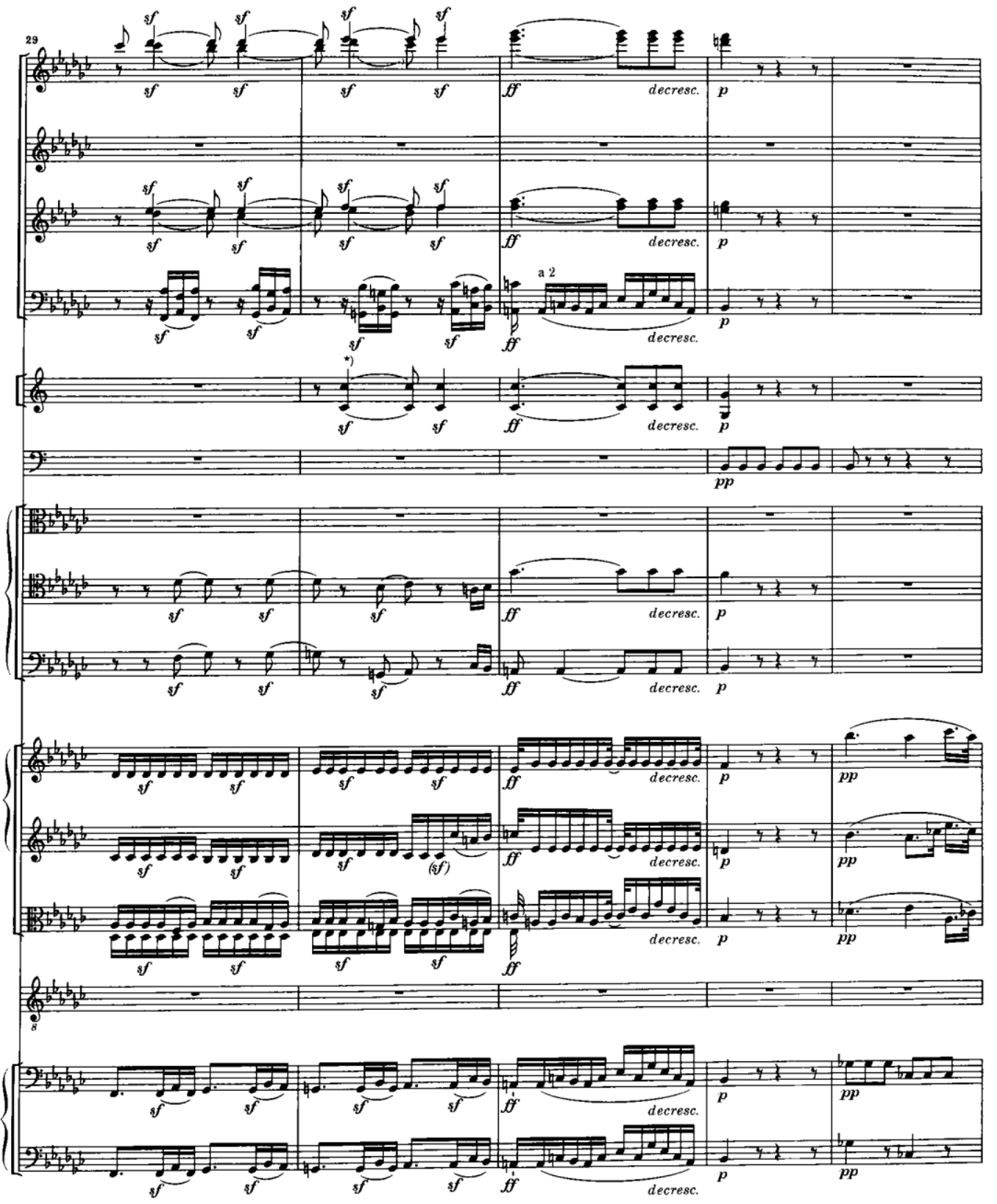

*) Zur Dynamik T. 30 siehe Kritissher Brricht, Lesartenverzeichnis. 


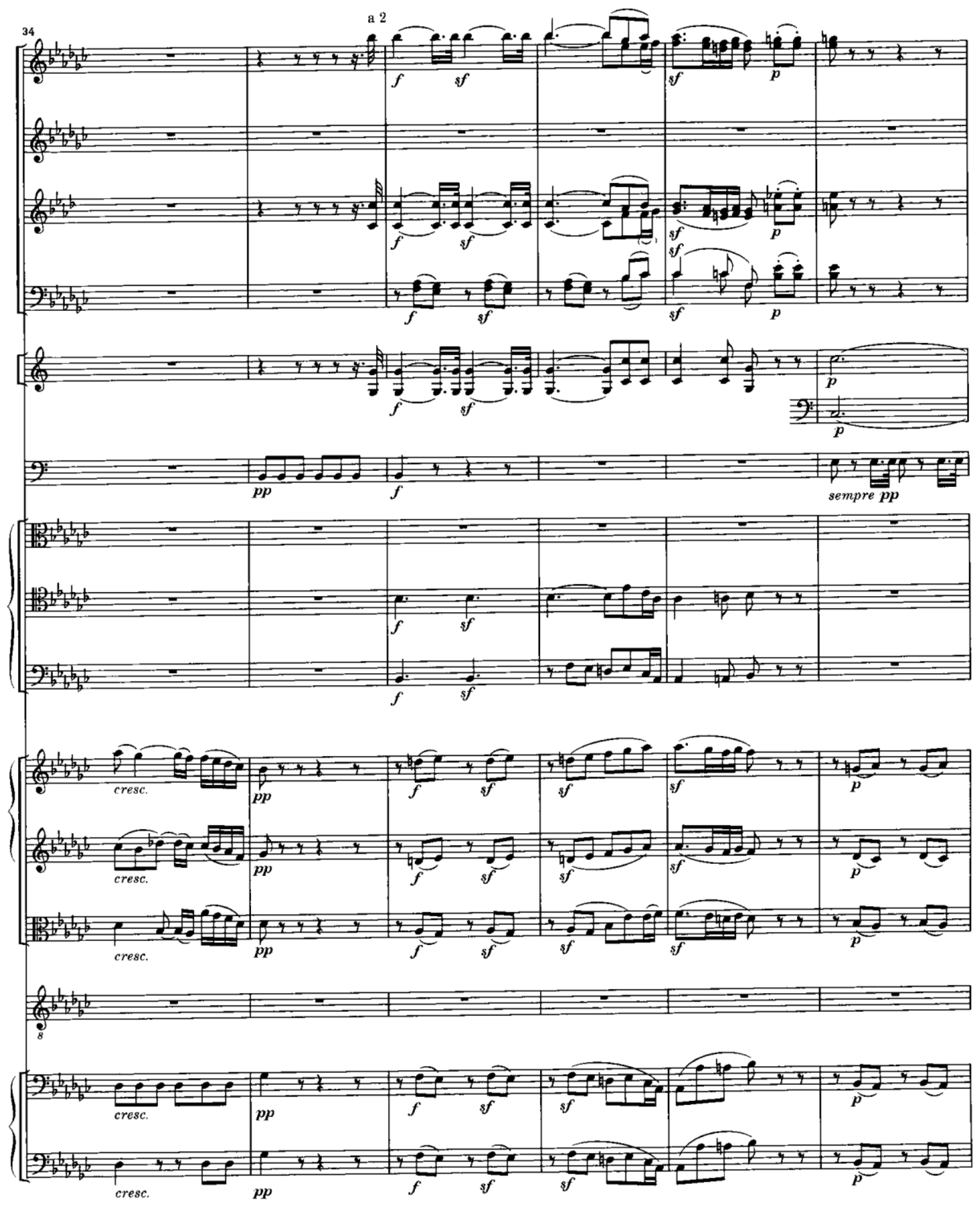




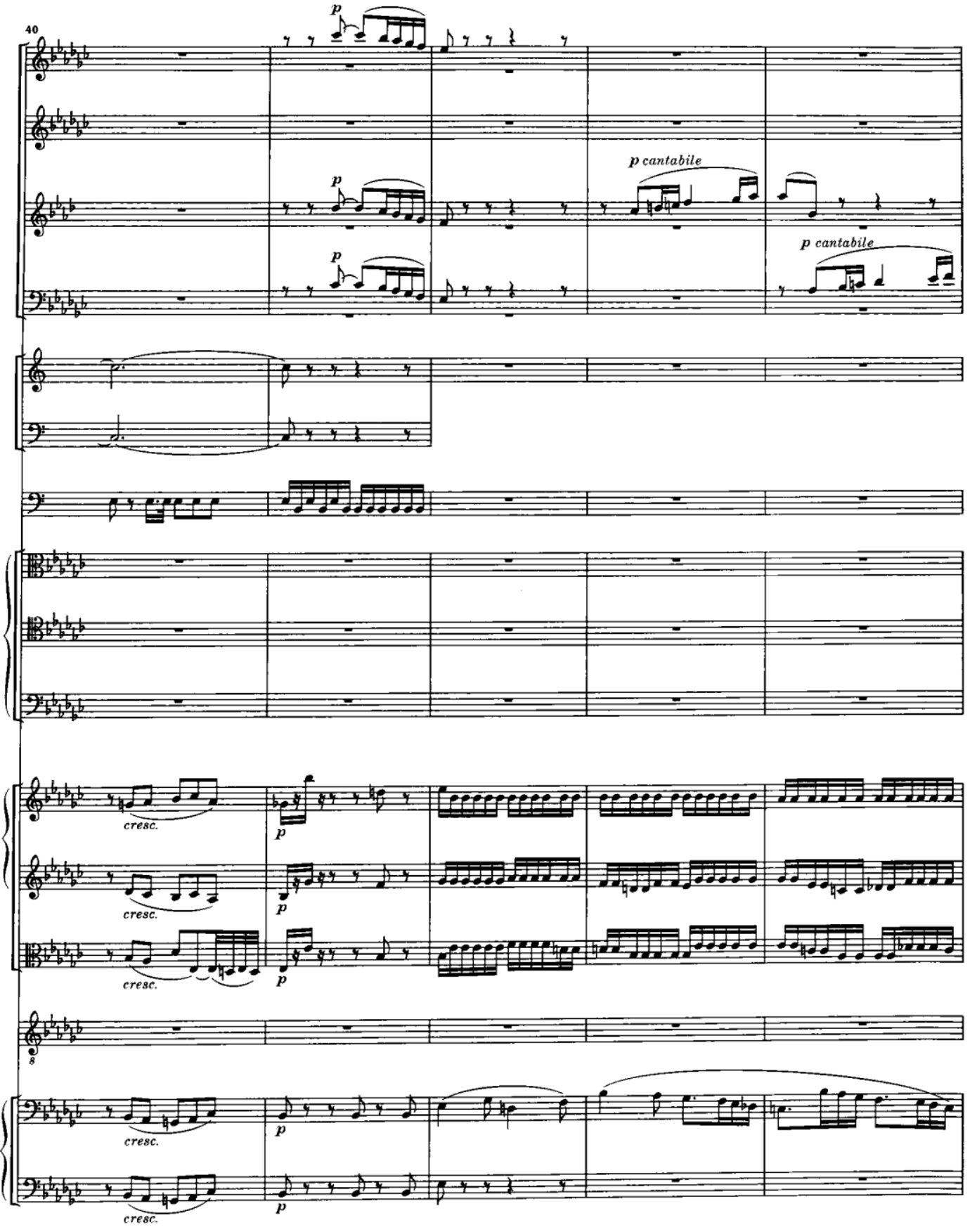



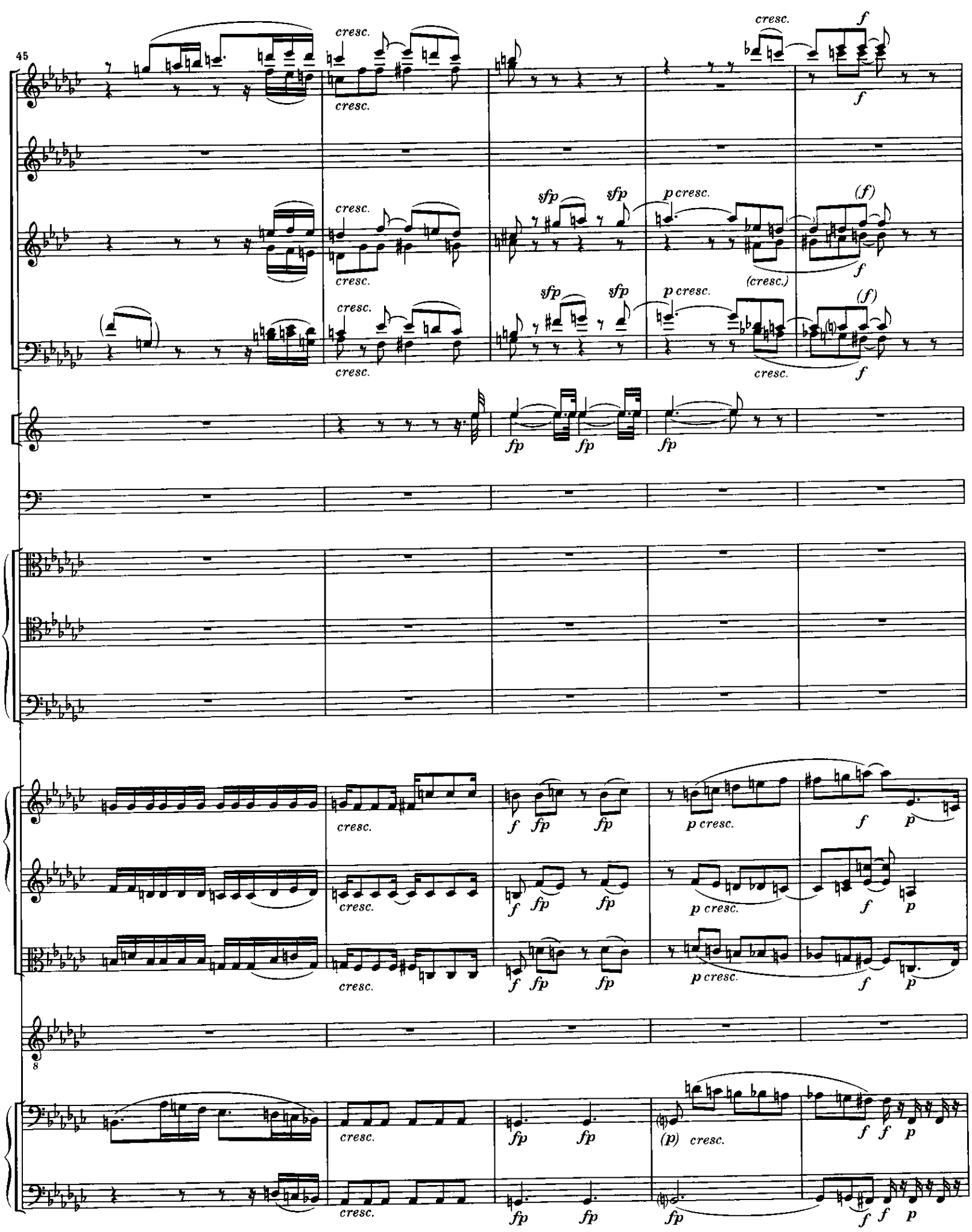

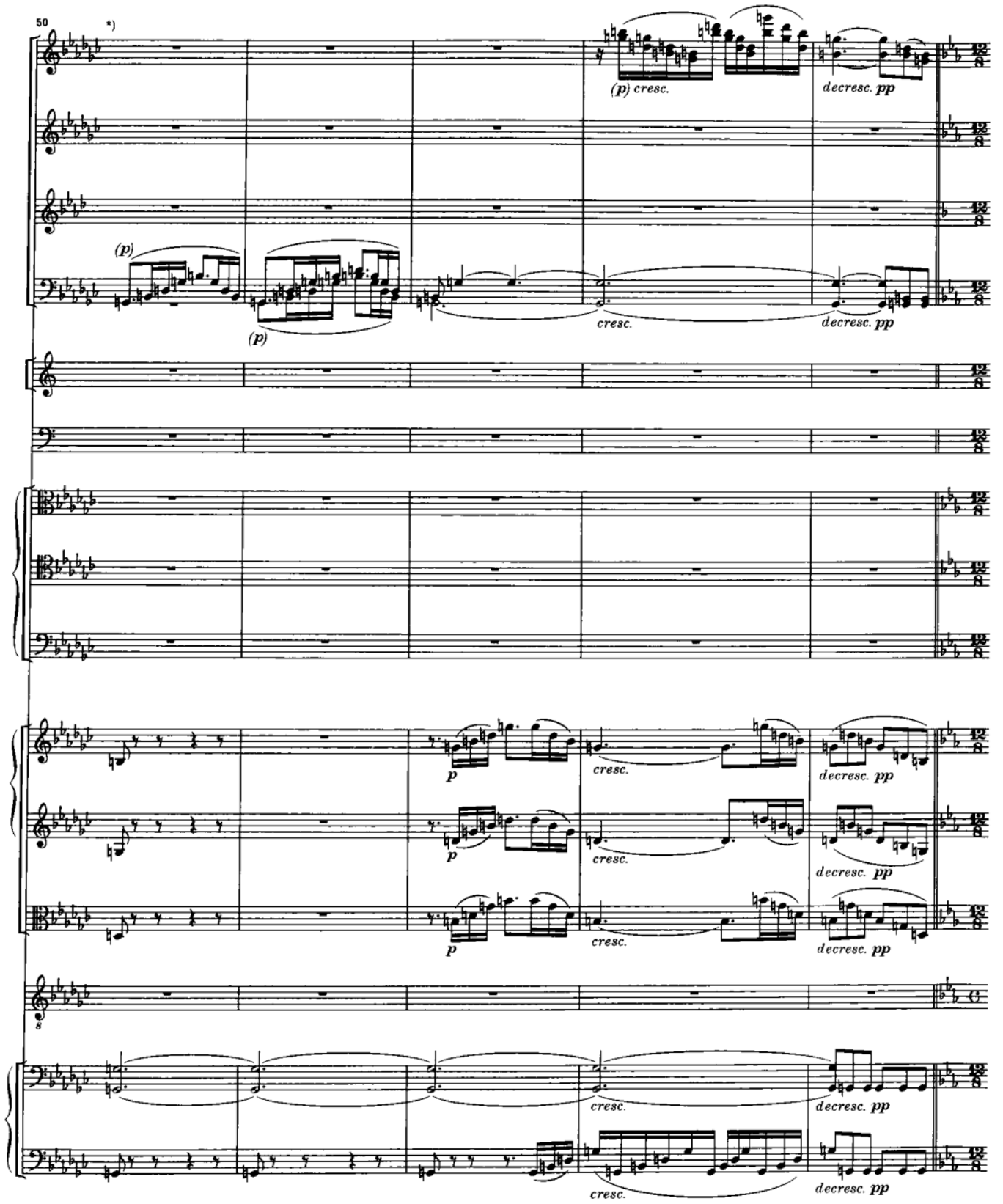

*) Zu abwrichender Lesart in A, T. 50-54 siehe Kritischer Bericht, Lesartenverzeichnis. 
Example 5: Beethoven Christus Recitative 1, "ich allein"

16

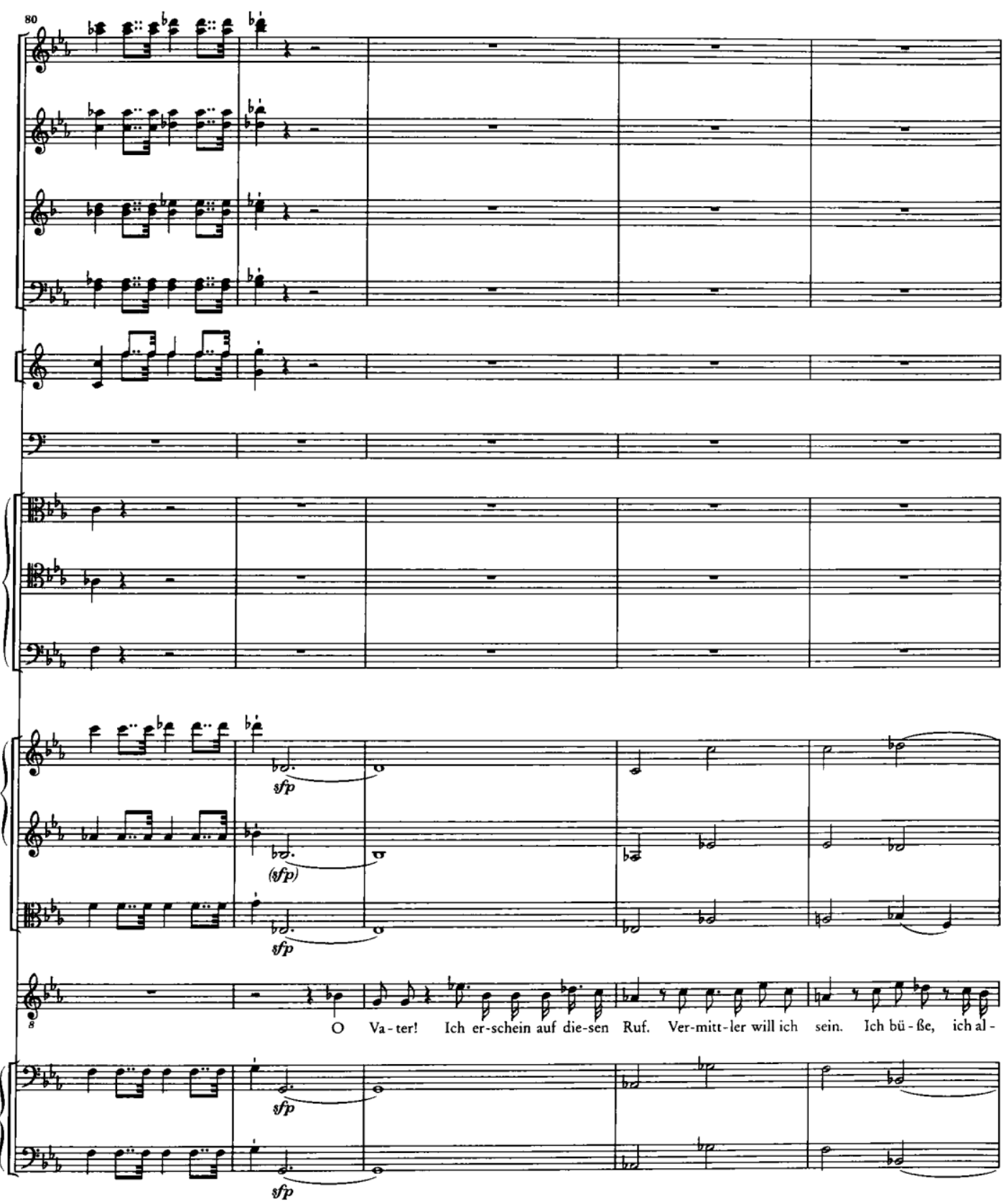



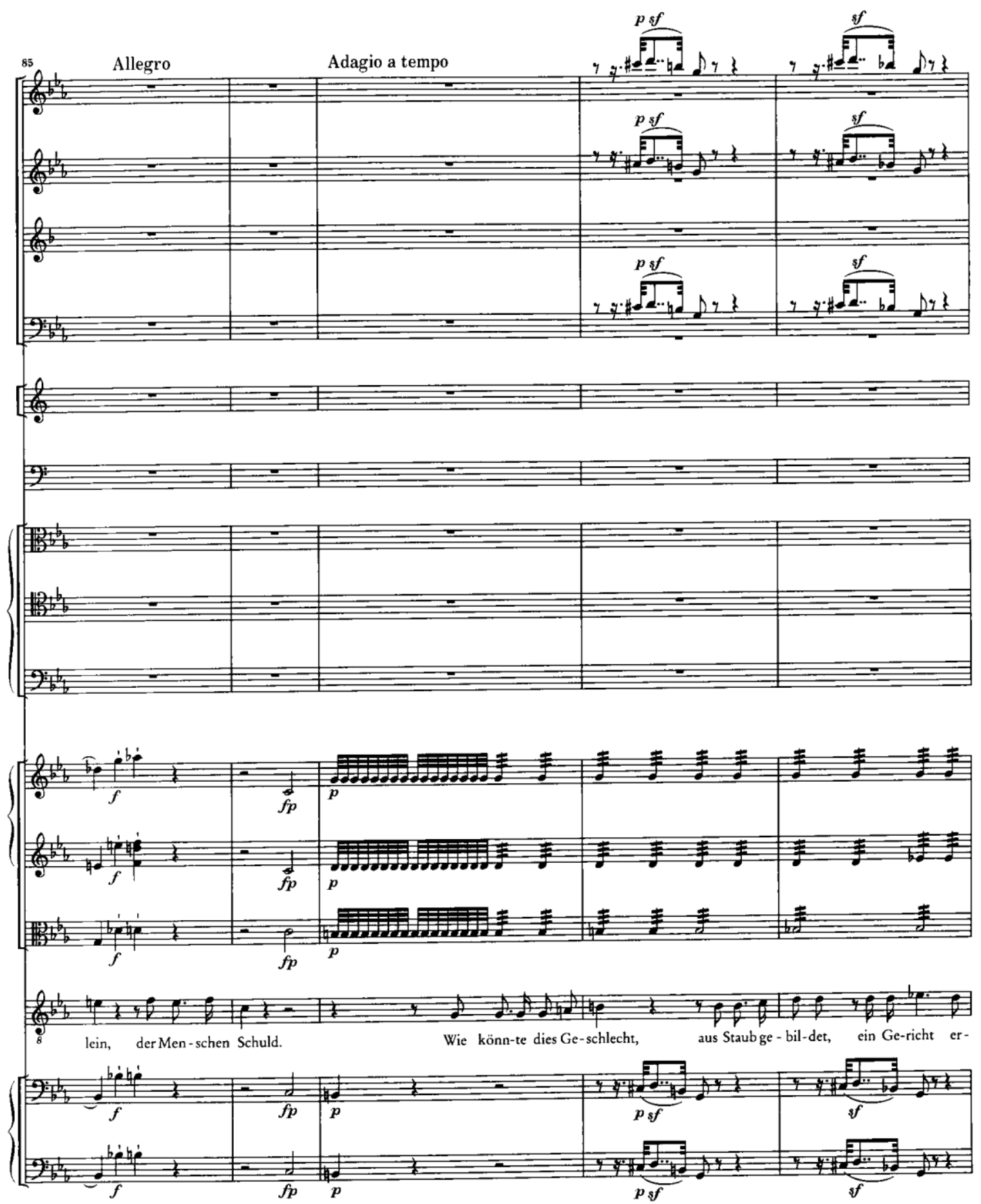
Example 6: Beethoven Christus Recitative 1, "erbarm dich mein"

20

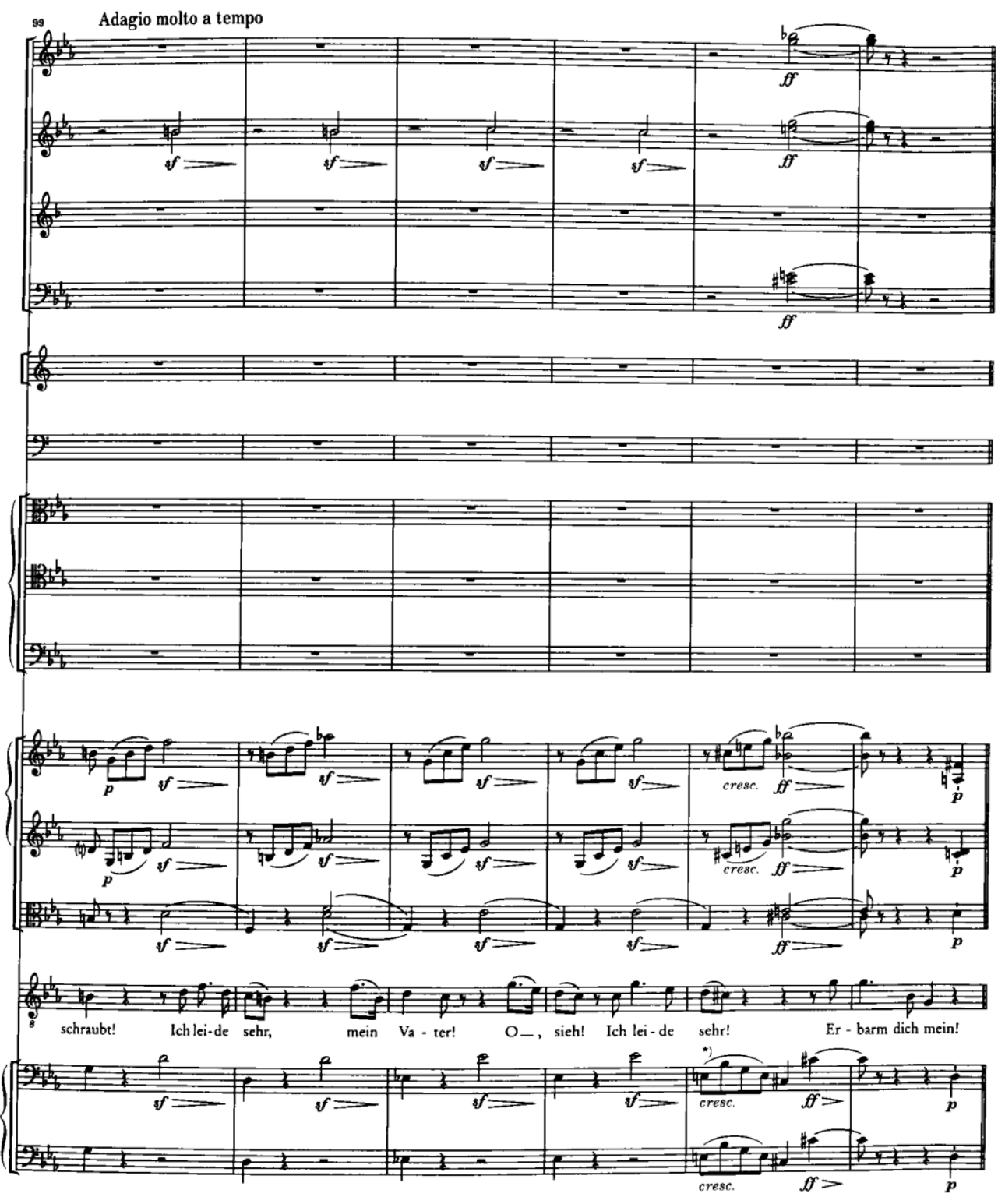

•) Zur ersten Fassung T. 103-104 siehe Kritischer Bericht, Anhang I. 


\section{Beyond the Classical Beethoven: The Songs}

The dominant tradition of writing about the Romantic Lied holds that the genre begins on 19 October 1814 with Schubert's "Gretchen am Spinnrade". ${ }^{124}$ Writers maintaining this view treat Schubert's songs as both exceptional and unprecedented, and give the impression that the Romantic Lied sprang fully formed out of Schubert's head, like Athena out of the head of Zeus. ${ }^{125}$ As James Parsons points out, scholars including Charles Rosen, Edward T. Cone, Lawrence Kramer, and Eric Sams have all argued that Schubert broke sharply with the past in this genre, as do, more recently, Peter Jost's article on the Lied in Die Musik in Geschichte und Gegenwart and Susan Youens's chapter in German Lieder in the Nineteenth Century. ${ }^{126}$ Yet this perspective ignores the complexities of the early Lied tradition and encourages its bifurcation into the "Romantic" Lied and the supposedly trifling songs that came before.

An important casualty of this view are Beethoven's songs, which for writers such as Rosen, Cone, and Kramer simply do not count as Lieder and therefore do not merit discussion. This attitude is reflected more recently in volumes such as German Lieder in the Nineteenth Century, from which discussion of Beethoven is notably absent. When Beethoven is mentioned at all as a song composer, as in the Cambridge Companion to the Lied, he is placed alongside C.P.E. Bach, Mozart, and Haydn. The reason is implicit but clear; these are composers who wrote in accordance with an Enlightenment-era aesthetic that stands in opposition to the

\footnotetext{
${ }^{124}$ See, for example, Marie-Agnes Dittrich, "The Lieder of Schubert," in The Cambridge Companion to the Lied, ed. James Parsons (Cambridge: Cambridge University Press, 2004): 83-100.

${ }^{125}$ Susan Youens, "Franz Schubert: The Lied Transformed," in German Lieder in the Nineteenth Century, ed. Rufus Hallmark, second edition (New York: Routledge, 2010); 35. Although she says this is not so, Youens also asserts that Schubert's songs "constitute nothing less than a new aesthetic of the Lied."

126 James Parsons, "The Eighteenth-Century Lied," in The Cambridge Companion to the Lied, ed. James Parsons (Cambridge: Cambridge University Press, 2004), 35.
} 
Romantic aesthetic of Schubert and those who followed. In this chapter we shall see how Beethoven's songs complicate this breezy categorization.

James Parsons and William Youngren have pointed out that the bifurcation between the Romantic Lied and its predecessors continues a nineteenth-century historiographical tradition that sees the history of the Lied in progressive terms with Schubert at the apex. Their scholarship has helped to clarify the history of the genre in the eighteenth century. And yet, despite all they do to illuminate the history of the Lied before Romanticism, Parsons and Youngren work largely within the familiar binary. Beethoven's songs continue to fall between the cracks of the two styles, and are not considered by most scholars writing about either Enlightenment or Romantic Lieder. Even an exception, like Amanda Glauert, mistakenly adopts the bifurcation between these two categories and places Beethoven in the Enlightenment tradition. ${ }^{127}$ This chapter corrects for the neglect of Beethoven's songs by Lieder scholars, by exploring the place of Beethoven's Goethe songs in the history of the Lied - Goethe, because his poetry plays such an important role in the Lieder that we do tend to consider "Romantic." Beethoven's Goethe settings point to the insufficiencies of the categories of Enlightenment and Romantic themselves and show that we cannot consider Beethoven's Lieder part of the Enlightenment tradition. ${ }^{128}$

Lied Aesthetics from the $18^{\text {th }}$ to the early $19^{\text {th }}$ century: The Enlightenment

As a professor at the University of Leipzig, Johann Christoph Gottsched (1700-1766) ushered Enlightenment aesthetics into Germany and influenced many later eighteenth-century

\footnotetext{
${ }^{127}$ Amanda Glauert, "The Lieder of Carl Philipp Emanuel Bach, Haydn, Mozart, and Beethoven," in The Cambridge Companion to the Lied, ed. James Parsons (Cambridge: Cambridge University Press, 2004), 63-84. Glauert makes this argument in part because she draws similarities between his songs and his other compositions, which have traditionally been understood as Classical style works.

${ }^{128}$ Parsons points out this problem poignantly in his article "Lieder c. 1740-1800" in The New Grove Online. Also see William H. Youngren, C.P.E. Bach and the Rebirth of Strophic Song (Lanham, MD: Scarecrow Press, 2003), 2, 68.
} 
poets, music critics, and composers. His Versuch einer critischen Dichtkunst of 1730 lays out an aesthetic of poetry that is governed by notions of clarity, elegance, naturalness, and unity in variety, in contrast to the learned complexities and perceived artificialities of the older Baroque aesthetic. ${ }^{129}$ Gottsched's chapter on odes and Lieder, a genre in which music and poetry are united, theorizes that song originated prior to poetry. When passions were aroused at social gatherings, poets sang spontaneously in praise of topics such as wine or heroes and expressed a single, clear emotion. Following the Roman poet Horace, Gottsched believed that poets should be models of sociable civility; their poetry should offer moral sentiments to listeners. Friedrich von Hagedorn's (1708-1754) Oden und Lieder of 1740 mark the shift to the new poetic style; his poetry is simple and clear, expresses a single emotion, and reflects its sociable intent. ${ }^{130}$

The Leipzig poet Johann Sigismund Scholze, alias Sperontes (1705-1750), who wrote in the new style, adapted a number of instrumental compositions as strophic settings for his own poetry. His collections, from 1736 on, were popular with the German middle classes; the texts express virtues of "patience, constancy, love, friendship, moderation and hope, and recount the delights of country and city life, the seasons, billiards, keyboard and card playing, tobacco, coffee and tea." Despite their popularity, many of the melodies, having originated as instrumental compositions, contain large leaps uncomfortable for the singer. ${ }^{131}$

Such awkward "Sperontisms" initiated a backlash among musicians, the first of whom, the composer and critic Johann Adolf Scheibe (1708-1776), was a student of Gottsched. In his journal Der critische Musikus of November 17, 1739, Scheibe advocates for simplicity and

\footnotetext{
${ }^{129}$ Youngren, 57, 131-38. Parsons, “Lied: c. 1740-1800," in Grove Music Online.

${ }^{130}$ These aesthetic notions are discussed by Jane Brown, "In the Beginning was Poetry," in The Cambridge Companion to the Lied, ed. James Parsons (Cambridge: Cambridge University Press, 2004), 16-18; Nicholas Boyle, Goethe: The Poet and the Age, vol. 1 (Oxford: Clarendon Press, 1991), 21.

${ }^{131}$ Robert L. Marshall and Diane M. McMullen, "Sperontes," in Grove Music Online.
} 
clarity in the melody, and argues that any melody should be singable by amateurs, even on first sight. He also favors the strophic over the through-composed song. Predominantly concerned with retaining unity in variety, Scheibe proposes that composers understand the overriding emotion of the complete poem before giving it a melody. ${ }^{132}$ In the preface to his 24 theils ernsthafte, theils scherzende Oden of 1741, Georg Philipp Telemann (1681-1767) follows Scheibe's prescriptions, furnishing simple, singable Lied melodies. Dedicated to Scheibe, the collection came out of conversations with the younger composer; like Scheibe, Telemann advocates for the Lied to express the meaning of all stanzas in its melody. ${ }^{133}$

Telemann's Lieder and Scheibe's ideas influenced writer and composer Christian Gottfried Krause (1719-1770), whose 1752 treatise Von der musikalischen Poesie continues the neo-classical focus on simplicity and naturalness, citing Horace. Along with the poet Karl Wilhelm Ramler (1725-1798), he published two sets of Oden mit Melodien in 1753 and 1755. These volumes included the works of numerous composers and poets including Krause himself, Hagedorn, and Carl Philipp Emanuel Bach (1714-1788), then also working in Berlin. ${ }^{134}$ Bach went on to write songs set to poetry of Christian Furchtegott Gellert (1715-1769). Gellert, a friend of Hagedorn, became professor of poetry and rhetoric at the University of Leipzig in 1745. Early on, he wrote neo-classical poetry similar to that of Hagedorn and Sperontes, but took a different direction in his work after the advent of a mysterious illness in 1752. His newer poetry retains the moral and social character of Hagedorn but adds to it a religious dimension; it

\footnotetext{
${ }^{132}$ Youngren, 141-143.

${ }^{133}$ Steven Zohn, "Georg Philipp Telemann: Secular Vocal Music," in Grove Music Online. Youngren, 53.

${ }^{134}$ Raymond A. Barr, "Krause," in Grove Music Online. Scholars have associated the work of Krause and Ramler with the beginning of the volkslied movement and the first Berlin song school, as Barr does in his Grove article. Both Parsons and Youngren argue against these identifications. They see in these labels influences of progressivist historians that look backward from the Romantic Lied, and point out that Krause never writes about the folk in his treatise. It was not until the publication of Herder's Volkslieder in 1778 that folk songs became popular. Youngren 3, 146. Parsons, "Lied: c. 1740-1800," Grove Music Online.
} 
combines Christian themes with Enlightenment naturalism, glorifies God and nature, and focuses on man's duty to serve both. His first collection with these themes, the Geistliche Lieder und Oden, was published in 1757. Popular with composers, Gellert's poetry was also set by Haydn and Beethoven. ${ }^{135}$

C.P.E. Bach's Lieder on the odes of Gellert follow the prescriptions of Scheibe, Telemann, and Krause. C.P.E. Bach was particularly moved after reading the Geistliche Lieder und Oden in 1757 and soon decided to set every poem in the book. In these songs, Bach continues to practice the aesthetic tenets laid out by Gottsched and his followers; they are strophic, unified, and elevate the melody. As Glauert and Parsons point out, Bach's songs innovate through their utilization of fully written-out accompaniments, enabling them to establish motivic unity between voice and accompaniment. Because they are written out, the accompaniments are able to be more expressive than the older figured bass lines, used in Lieder by Telemann and others. ${ }^{136}$

In Vienna, Franz Joseph Haydn (1732-1809) also set many of Gellert's poems, and considered the poet to be his hero. ${ }^{137}$ Haydn's Gellert songs are not Lieder; they are set for mixed voices with accompaniment, are polyphonic, and at least two are through-composed. Still, they exhibit certain Enlightenment song traits; their content, matching Gellert's moral messages, is generally celebratory and reverent, is occasionally distressed, and is affectively unified.

Though Wolfgang Amadeus Mozart (1756-1791) probably never set Gellert's poetry, most of his song texts express similar themes; the celebration of the world as created by God,

\footnotetext{
${ }^{135}$ Youngren, 203-205.

${ }^{136}$ Amanda Glauert "The Lieder of Carl Philipp Emanuel Bach, Haydn, Mozart, and Beethoven," 63-68. Parsons, "Lieder c. 1740-1800."

${ }^{137}$ David P. Schroeder, "Haydn and Gellert: Parallels in Eighteenth-Century Music and Literature." Current Musicology 35 (1983), 8.
} 
and the pursuit of a virtuous life within that world. ${ }^{138}$ The nature of the virtuous life has several facets, which are illuminated in the different poems. For example, in two poems of the same name, "Die Zufriedenheit," (“Contentment”) one by Johann Martin Miller (1750-1814) and the other by Christian Felix Weiße (1726-1804), the narrator expresses his contentedness with owning little and with taking pleasure in God-given nature. Similarly, Johann Timotheus Hermes' (1738-1821) "Verdankt sei es dem Glanz der Grossen” (“I am indebted to the Splendor of the Great World") celebrates the greatness of the world over the insignificance of the narrator, and reiterates that "Es sei nicht Schande, klein zu sein" ("there is no shame in being small"). ${ }^{139}$

In addition to humility, another facet of the virtuous life is the traveler's pursuit of knowledge, portrayed in these poems as a difficult but worthy goal. In the "Lied zur Gesellenreise” (“Song to Journeyman’s Trip”) of Joseph Franz von Ratschky (1757-1810), the narrator is both encouraging and cautionary, informing the reader of the perils and the benefits to the quest for knowledge saying "Rauh ist zwar des Lebens Reise/Aber süß ist auch der Preis" ("Life's journey is coarse and rough/but sweet is the reward"). And in Hermes' "Ich würd' auf meinem Pfad," (“I would on my path") the protagonist's intense suffering is ultimately validated by triumphantly proclaiming "brech' ich mutig durch die Dornen" ("I break bravely through the thorns").

Throughout these poems, there is a sense that by following the advice given, one will not only live virtuously but also find oneself in good company. Both poems celebrating the pursuit of knowledge, for example, include other characters who offer support along the way. In 'Ich würd'

\footnotetext{
${ }^{138}$ Mozart may have written 15 Gellert songs, but these could have been written by his father. See "Mozart: Works," Grove Music Online.

${ }^{139}$ For reference to all of the Mozart songs under discussion, see his Complete Songs for Medium Voice, Bärenreiter Kassel; Neue Mozart Ausgabe, 1999.
} 
auf meinem Pfad," the traveller's friend empathizes in his struggle and offers verbal support more than once, at one point calling out "Ich kenne deine Not!" ("I know your peril!"). In the "Lied zur Gesellenreise," the narrator encourages us to "Nehmt, o Pilger, zum Geleite/Eurer Brüder Segen mit!” (“Take with you, o pilgrims, the blessings of your brothers as your guide!”). Even "Sei du mein Trost" ("Be thou my comfort [silent melancholy]") by Hermes, in expressing the comfort of solitary melancholy, makes clear the impropriety of melancholic expression in front of company, saying "nie klag' ich Glücklichen mein Leid/so schweigt ein Kranker bei Gesunden" ("never would I lament my suffering to the fortunate/as a sick man is quiet in the company of the healthy").

While his accompaniments are more intricate and difficult than those of his North German contemporaries, Mozart's settings of these poems share the most important conventions of, say, Bach's Lieder. In particular, the way in which music and text interact is quite similar. His vocal lines maintain pride of place over the accompaniments, which in turn serve to illuminate and clarify the meaning of the poetry. The affect is consistently unified, the phrase structure clear and balanced, and the form always strophic.

In the settings mentioned above, the music sets up a dominant affect in the prelude, which is then maintained throughout. In "Lied zur Gesellenreise" and "Die Zufriedenheit," for example, the piano preludes present a nearly complete statement of the melody before the entrance of the singer. Once the voice enters, the accompaniment becomes subordinate but repeats its previous phrase. In these two cases, the affect that is set up is generally congenial. In "Ich würd' auf meinem Pfad," the feeling of storm and stress is established immediately through the descending chromatic harmonies. This song is an excellent example of formal and affective unity, as its fourteen measures constitute a single phrase that expresses a single emotion. 
This sense of sociability in Mozart's song texts mirrors what Jane Brown points to as one of the defining differences between Gottschedian poetry and Goethe's poetry; the former enables a sense of group identity, while the latter replaces the group with a two-voiced character, an individual who addresses himself. This difference is reflected in the later settings of Goethe that we will discuss presently. ${ }^{140}$

New Directions in Aesthetics: Poetry

Influenced by the ideas of German Enlightenment thinker Johann Gottfried von Herder (1744-1803), Johann Wolfgang von Goethe (1749-1832), poet, prose writer, natural scientist, statesman, and critic, initiated a major challenge to Gottsched's poetics. In contrast to Gottsched's assertion that song grew out of social settings, Herder's Abhandlung über den Ursprung der Sprache (Essay on the Origin of Language) of 1772 theorizes a pre-social, instinctual origin of language and song, and argues that the earliest humans uttered their first cries in isolation as a response to environmental forces.

Goethe absorbed Herder's ideas into his poetry. "Wonne der Wehmut," for example, portrays lonely suffering in its two stanzas; it also expresses that meaning is created through reflection on this suffering. These two aspects of this short poem point to an isolation that inverts the sociability of Mozart's song texts, Gellert's poetry, and Hagedorn's odes; they also reflect a sense that the self is being created through interiorized emotion and reflection. ${ }^{141}$

Goethe uses the new primacy of emotion and reflection to tell stories of internal change in his poetry. His "Sehnsucht (Was zieht mir)", set by Reichardt, Beethoven, and Schubert, elaborates a story in which the narrator experiences quickly changing emotions. Despite

\footnotetext{
${ }^{140}$ See Brown, "In the Beginning was Poetry," 20-21.

${ }^{141}$ Boyle, Goethe: The Poet and the Age, volume I, 109-110; 165-168.
} 
Goethe's insistence on the importance of formal parameters in both poetry and music, this poetry mixes the genres of lyric and dramatic poetry. These poems presented a special challenge for songwriting, which usually used static lyric poetry in the older style.

Even as aesthetics changed, however, contemporary Lieder did not immediately reflect these differences. Composer and critic Johann Friedrich Reichardt (1752-1814), also influenced by Herder's writings, was an early friend of Goethe and composed settings of many of his poems. Herder's emphasis on the pre-social origins of language and song stressed song's naturalness to a greater degree than Gottsched and his followers. Reichardt thus criticized C.P.E. Bach, whose music he viewed as overly artificial. Though Reichardt's thinking about Lieder was informed by Herder, his compositions could be mistaken for those of his predecessors. Reichardt maintained the strophic form and elevation of simple melody advocated by Scheibe and Krause. ${ }^{142}$

Carl Friedrich Zelter (1758-1832), a long-time friend of Goethe who also set many of his poems, speaks to these two composers' continuity in Lied style. In a letter from 1824, Zelter describes his songwriting principles, which sound as if they could have been written by Scheibe nearly a century earlier: the text takes priority; the strophic song supersedes the throughcomposed song; the accompaniment recedes into the background, to the extent that the melody could stand up without it. ${ }^{143}$

Goethe had strong opinions on the aesthetic of the Lied. Like Zelter and Reichardt, the writer believed in the importance of strophic song; he also thought that the song should express the whole character of the poem in its single melody. Goethe was particularly insistent that just

\footnotetext{
${ }^{142}$ Youngren, 3-5.

${ }^{143}$ Hans-Gunter Ottenberg, "Zelter, Carl Friedrich," Grove Music Online.
} 
as he observed poetic forms of rhyme and meter, so too should the strophic musical form be maintained. Thus, Goethe took his understanding of the Lied from Krause and Scheibe, even as the content of his poetry had shed the influence of Gottsched. ${ }^{144}$

\section{New Directions in Aesthetics: The Lied}

According to scholars such as Susan Youens, Marie-Agnes Dittrich, Harry Seelig, and Eric Sams, music caught up with Goethe's poetry with the emergence of Schubert and the Romantic Lied. This new style of songwriting matches Goethe's poetry better than strophic song: Goethe's dramatic lyric style of poetry enabled song that was both through-composed — that is, told a narrative - and was expressive of subjective feelings; the poetic themes that set an individual against uncontrollable external forces facilitated music expressing alienation and doubt; and his focus on the connection between external events and individual feelings allowed song to represent both using text-painting. ${ }^{145}$

These descriptors fit Beethoven's Goethe songs well. But because of his firm association with Viennese Classicism and the Enlightenment, these songs are judged within this context. According to the criteria of Reichardt, Zelter, Mozart, or Goethe himself, Beethoven's Goethe settings fail. His songs depart from strophic form, the vocal lines are challenging, his

\footnotetext{
${ }^{144}$ Lorraine Byrne Bodley, Schubert's Goethe Settings (Surrey, England: Ashgate, 2003), 10-13.

${ }^{145}$ These characteristics, among others, overlap in discussions by Eric Sams, "Lied," Grove Music Online; Dittrich, "The Lieder of Schubert"; Youens, "Franz Schubert: The Lied Transformed"; Harry Seelig, "The Literary Context: Goethe as Source and Catalyst," in German Lieder in the Nineteenth Century, ed. Rufus Hallmark, second edition (New York: Routledge, 2010), 1-34. Sams stands out as cautious in his portrayal of Schubert as the first Romantic Lied composer, remarking that the composer may have made no unique innovation in song composition. He is also careful to acknowledge that Beethoven "can plausibly be claimed to have created the Lied." Exactly what he means by this remains unclear, though, since his next sentence proclaims that Beethoven "remains in the $18^{\text {th }}$ century tradition of self-effacing enhancement of the words." Sams also promulgates a progressivist narrative of the Lied, using the language of development and growth to describe its history.
} 
accompaniments are difficult and infringe on the prominence of the melody, and his affects shift within songs and contradict each other.

Amanda Glauert's discussion of Beethoven's songs shows the pitfalls of placing Beethoven in an Enlightenment context. In The Cambridge Companion to the Lied, her chapter groups together C.P.E. Bach, Haydn, Mozart, and Beethoven together under the rubric "The Birth and Early History of a Genre in the Age of Enlightenment," thus inviting comparison between Beethoven and the earlier composers. While the other three composers largely adhere to Gottsched's precepts, Beethoven is more difficult to pin down. To accommodate his Goethe songs, Glauert uses his 1803 settings of the eighteenth-century moralizing poet Christan Furchtegott Gellert as the standard by which these later songs should be judged. Glauert posits that the Gellert songs establish Beethoven's relationship to the formal and aesthetic restrictions of the Lied, and that in his later Goethe settings we may hear this constriction manifest itself. Glauert points to the modified strophic form of "Was zieht mir das Herz so," the balanced tonic and dominant large-scale harmonies of "Kennst du das Land," and the motivic development, harmonic departure and return of "Wonne der Wehmuth." She concludes that in these songs, Beethoven brings the symphonic classical style to the Lied. ${ }^{146}$

William Kinderman also emphasizes structural values by searching for motivic unity in Beethoven's Goethe songs. Focusing on "Wonne der Wehmut," Kinderman shows how the Beethoven uses the falling scale as a structural motif and the pitch of $G$ natural in various ways throughout the song. Kinderman strives to show the structural coherence of this song, which he finds at the end of the song; Beethoven finally completes the descending scale, which concludes the song at the tonic pitch.

${ }^{146}$ Glauert, 81-82. 
While these observations may be accurate, Glauert and Kinderman both ignore important features of Beethoven's Goethe songs that distinguish them from C.P.E. Bach and Mozart's Lieder. As I discuss in more detail in my analysis of these three songs, consideration of the affective content of the poetry and music as well as Beethoven's departure from structural norms problematizes the understanding of Beethoven's Lieder as part of the Enlightenment.

\section{Kennst du das Land}

The first setting is of Goethe's "Kennst du das Land" from Wilhelm Meisters Lehrjahre, his most commonly set poem from the book. ${ }^{147}$ Mignon, the mysterious, solemn young girl who enjoys Wilhelm's favor after he pities her forlorn situation, sings this song at the opening of the third book. "Kennst du das Land" at first relays Mignon's longing for her homeland but becomes more fantastical as it progresses, moving from a land filled with fruit trees through an ancient hall to a misty mountain filled with dragons. A change in affect comes with each movement of location; the poem narrates a story of emotion that ranges from tranquility to fear.

Throughout, Mignon's goal remains just out of reach. While her questions - do you know the land? Do you know the house? Do you know the mountain?_-imply a lonely search for a companion, they also point to the possibility of fulfillment. Though these questions receive responses - there, there I would like to go! - their fulfillment is never attained. Instead, they continue to point toward a far-off place, perpetuating the isolation and yearning first articulated through the questions. The loneliness central to this poem is at odds with the sociability characteristic of Gottschedian poetry.

\section{Reichardt's version}

\footnotetext{
${ }^{147}$ George E. Luntz, Musical and Literary Expression in Songs from Goethe's Wilhelm Meister (Ph.D. dissertation, State University of lowa, 1953), 147.
} 
Reichardt's version was included in the original edition of the novel, and Goethe considered it to be an excellent setting of the text. The setting exemplifies features of the Enlightenment Lied: the strophic form's melody is general enough to contain the three stanzas' various meanings, and Reichardt makes the accompaniment subservient to the melody. ${ }^{148}$

While the affect of each stanza progresses from longing to suffering to frightening, the song's melody embraces these various emotions; a chromaticized, ascending melodic line at "die Myrte still" develops an intensity that is resolved at an authentic cadence on the dominant by "steht".

The subservient accompaniment retains the clarity of the text while also producing a limited accompanimental texture. The keyboard part consists mostly of quarter notes or larger rhythmic values, serving its major purpose of providing harmony but otherwise remaining consistently in the background. When eighth notes are present, they double the melodic line. Because of this rhythmic homogeneity, the keyboard texture always reinforces the melody.

The harmony, however, expressively accentuates the text. Two instances, occurring in succession, stand out from the rest of the song. At Mignon's exclamation of "dahin!" (measure 18), a climax at which she answers the question she has asked from the beginning, Reichardt sets up a falling motive with an appoggiatura, then repeats it upon the repetition of the word "dahin!" While the first instance finds expression through an appoggiatura, its diatonic harmonies limit its expressivity. Upon the repetition of this motive, however, Reichardt inserts a secondary dominant (vii/iii) which resolves to a mediant chord altered to the major (V6/vi) (example). This $\mathrm{G}$ major chord is the most remote harmony from the home key of $\mathrm{E}$ flat. Its presence at this

${ }^{148}$ Luntz, 151. 
important repetition of "dahin!" combined with the expressive appoggiatura, as well as the song's only crescendo, amplifies the intensity of the affect here.

Following this, the melody hangs on an augmented fifth above the root, on the same pitch that constituted the altered G major chord the measure before. The foreignness of this b natural, both in the context of the altered mediant harmony and in its second instance as an augmented interval, points to the loneliness and longing in Goethe's poem. This instance of expression, however, remains within a basically consistent texture; along with Reichardt's strophic form, the affective unity of this song speaks to its Enlightenment credentials.

\section{Zelter's version}

Notwithstanding his letter professing loyalty to Scheibe's precepts, Zelter's setting diverges more than Reichardt's from the old Lied aesthetic. While it retains a strophic form, the song also varies the second and third strophes to match the change in poetic affect. And although it clearly remains subservient to the melody, the accompaniment draws attention to itself in an instance of text-painting.

Zelter uses the same harmonic hook, the altered major mediant chord (V/vi), as Reichardt to express longing at the word "dahin!". But while Reichardt saves the harmony for this important moment, Zelter first introduces it as a way to ask the question "kennst du das land?" in only the second measure. The chord becomes something like a motive in Zelter's setting, returning three more times in each stanza at the mention of "dahin!" and even showing up as the only measure-long interlude in the song. This harmonic motive is joined with rhythmic and melodic components, the former consisting of a dotted quarter rhythm and the latter the interval of a falling second. 
The song is also similar in texture to Reichardt's; the accompaniment consists mostly of block chords that include the melody notes. Although it normally remains inconspicuous, the left hand of the keyboard at "ein sanfter wind" draws attention to itself. At this moment, an arpeggiated accompaniment separates the texture into two parts, the harmony rests on a dominant chord, and Mignon imagines a peaceful land. Even here, though, the accompaniment plays a supporting role. Mignon is dreaming of a soft wind and the plants and trees growing in an idyllic landscape, an image captured by Zelter through his static harmony and rolling arpeggios.

If the rising and falling motive, which returns in each stanza, suggests a gentle breeze in the first stanza, in the second and third stanzas there is no mention of a breeze. Instead, the second stanza takes a somber tone at the same moment, with Mignon speaking of herself as a poor child (armer Kind), and the third describes a sheer cliff and a surge of rushing water. Zelter deals with this discrepancy in tone by inserting darker parallel minor harmonies while retaining the same left hand arpeggios, as well as a cascading effect using parallel sixths in the right hand.

The settings of Reichardt and Zelter hold mostly to the prescriptions of the Enlightenment Lied. Their accompaniments are always subservient to the melodies; Reichardt's version is strophic, while Zelter's varies slightly; both versions could be performed by amateurs. Despite this, some traits of these songs reflect Goethe's new loneliness and his narrative of emotions: both composers' foreign harmonies express Mignon's loneliness, and Zelter modifies his accompaniment to match the changing affects.

Beethoven's version

Beethoven's version disregards the major strands of the Enlightenment Lied: the form is modified strophic, the accompaniment splits attention with the melody, and the affect changes 
often and quickly. By eschewing these imperatives of the lied tradition, Beethoven musically accentuates the concerns of Goethe's aesthetic: the varied affects within stanzas show the uncertainty of the new solitude; the modified strophic form changes meaning to match the final strophe; the prominent accompaniment communicates self-reflection. Beethoven's "Kennst du das Land" departs from the concerns of the older lied while constructing a new aesthetic using Goethe's poetry.

The first change of affect comes in the four opening measures. With their emphasis on the strong beats, a rising scalar melody, and a forte dynamic, the first two measures of music assert forcefulness; after the long dotted quarter note on "Land," however, the tentative repeated melodic pitches, the lyrical leap of a fourth, and the piano dynamic suggest gentleness. At "ein sanfter Wind," Wilhelm Meister describes Mignon's somber tone; here, the left hand triplets and modal shift to A minor initiates a textural and mood shift to match the description. ${ }^{149}$ At this point, the intensity increases, culminating in a forte cadence on F major at "Lorbeer". This cadence, however, is immediately undermined by a D minor chord, and the excitement of this phrase ending immediately deflates by the end of the measure. The juxtaposition here of excitement and gravitas, and earlier of solemnity and wistfulness, introduces a musical interiority in the Lied not present in Reichardt, Zelter, or Mozart; Beethoven's "Kennst du das Land" accommodates conflicting inner emotions.

Beethoven also demarcates the musical structure using a shift in affect; while Reichardt and Zelter position their most expressive harmonies at "dahin!", Beethoven initiates a new

\footnotetext{
${ }^{149}$ Ironically, Goethe criticized Beethoven's version for not following the spirit of the text; he also was less than pleased about Beethoven's use of modified strophic form. Lorraine Byrne Bodley agrees with Goethe's assessment, writing that "his remarks are still musically valid...he recognizes how the composer disregards the spirit of his song, and his criticism is largely based upon this defect." Bodley, Schubert's Goethe Settings, 261-62.
} 
section of the song at this word with a time signature change. Because the quicker triple meter replaces duple and the keyboard plays on every division, the mood changes here from hesitatingly inquisitive to dreamily ecstatic. The emotion here remains optimistic for some time, and only begins to deflate as the stanza draws to a close. As Mignon repeats "dahin!" two more times, the accompaniment oscillates between A major and a tonicized D major; each G sharp elevates the mood, while each $\mathrm{G}$ natural shrinks it down again.

The third stanza, with its caverns, dragons, and rushing water, is more frightening than the other two. Beethoven intensifies his accompaniment to account for this change; at "Höhlen" the left hand plays sixteenths instead of triplet eighth notes, and the right hand plays octaves. Zelter also employs a varied strophic form, but Beethoven's involved accompaniment is more dramatic.

Beethoven's style in this song is foreshadowed in Mozart's "Das Veilchen," a text of Goethe. Like Beethoven's “Kennst du das Land,” Mozart's song changes affect throughout, avoids strophic form, and uses a prominent and engaged accompaniment. In so doing, the music presents a commentary on the events in the narrative; Beethoven's music, in contrast, represents the inner feelings of the protagonist. The distinction is fine but important, and begins with the difference in text.

"Das Veilchen," from Erwin und Elmire, a comic opera of 1775, tells the story of an anthropomorphized little violet that encounters a shepherdess and wishes it were exceptionally beautiful so that she would notice; instead, she tramples and kills it. But the violet is still happy, because it died through the shepherdess. The difference from Mozart's other texts and the other 
pre-Goethe poetry is apparent here; the violet wishes for greatness rather than humility, and the poem glorifies the beloved rather than God.

Like Mignon, the violet expresses an unsatisfied yearning; unlike "Kennst du das Land," a narrator mediates, telling the violet's tale for it. The split between the narrator and the protagonist of "Das Veilchen" is reflected in the music, which remains apart from the interior emotions of the violet. The accompaniment narrates the action taking place in the text: when the shepherdess sings, Mozart inserts a melodic interlude; when she steps on the violet, the accompaniment reacts with mock-horror diminished chords; when it becomes clear that the violet is happy to be killed in this way, the keyboard plays amiable arpeggios. However, this is not the visceral reaction of an experienced emotion. In all three cases, the accompaniment only acts after a period of reflection; after the words have been spoken, the music finds a way to represent them. The temporal distance between spoken sentiment and musical representation effectively inserts a separated, narrated relationship. Because of this distance, the accompaniment produces a humorous effect; the violet's tragedy is the narration's comedy. In this way, the affect of the accompaniment diverges from the concerns of the violet.

This setting is an important precursor to Beethoven's songs in the way that it disregards the formal prescriptions of the lied in order to tell a dramatic, affective story. Because Mozart uses the accompaniment to represent a narrated, mediated perspective, though, it stops short of completing an aesthetic transition to a fully interiorized lied.

\section{Schubert's version}

With Schubert's position at the center of the Lied, it is unsurprising that more has not been made of the influence of Beethoven's songs on the young composer. Schubert's “Kennst du 
das Land," a song that has been repeatedly dismissed by Lied scholars, is strong evidence for this influence. Schubert's version seems to have been modeled on Beethoven's; the form and textures are nearly identical. ${ }^{150}$

Within the first stanza, Schubert's setting mimics Beethoven's: Schubert places the first two lines in a period structure, which culminates in a triplet-sixteenth accompaniment at "ein sanfter Wind;" he modulates to F major while also crescendoing at "Lorbeer steht;" he inserts a two-measure-long accompanimental interlude before the phrase "kennst du es wohl?" and ends this phrase with the same half cadence prepared by half-step. Schubert also changes the tempo for the "dahin" section through the marking "etwas geschwinder." His continued use of triplet sixteenths throughout this section resembles Beethoven's setting as well because it recreates the feel of the compound time signature; finally, like Beethoven, Schubert modulates to the subdominant, $d$ major. Like Beethoven, Schubert changes the music in the third stanza to accommodate for the frightening meaning, placing the first half in the parallel minor and inserting octaves.

Harmonic subtleties that resemble Beethoven's suggest a playful reimagining of the older composer's version. Beethoven shifts to the parallel minor at "ein sanfter Wind," thus giving significance to the $\mathrm{C}$ natural as the first accidental. In his version, Schubert uses the same pitch as his first accidental, but instead modulates to $\mathrm{C}$ major. While Beethoven reserves for "kennst du es wohl?" the half cadence prepared by descending half step, Schubert introduces the idea already at "Himmel weht." Beethoven arrives at the key of F major at "Lorbeer;" Schubert is there a measure earlier, by "Myrthe."

${ }^{150}$ Bodley, Schubert's Goethe Settings, 260. 
Despite evident similarities, their settings diverge in some ways. While Beethoven's version vacillates between conflicting emotions of optimism and doubt, Schubert's is more clearly optimistic, particularly at two important moments: at "Lorbeer" Beethoven juxtaposes F major and D minor harmonies, and Schubert unambiguously arrives at $\mathrm{F}$ major; at the last repetition of "dahin!” Beethoven oscillates between D major and A major, while Schubert triumphantly concludes at A major.

\section{Wonne der Wehmut}

Goethe's Wonne der Wehmut is a short lyric poem that valorizes the suffering of love as a way to bring back to life a sterile and dead world. The poem places particular importance on the intensity of the feeling, which must be fully present in order for the world to seem alive ("even to the half-dry eye/how desolate and dead the world appears"). ${ }^{151}$ Several features of this stand out. First, this poem is conspicuously lacking the sociable emotions of Mozart's texts. Instead, there is a dialogue with oneself - the addressee of the first line is the addressor's eyes. We assume that he is alone, or at least that he and his eyes are the only two important subjects here. Second, the assumed significance, the clear meaning inherent in the world which Mozart's song texts espouse is no longer present. Instead, the narrator of Wonne der Wehmut creates meaning only through the act of crying and the feeling of melancholy. Finally, the goodness of the world, the positive optimism of Mozart's song texts that is reflected in his music, is negated here. Instead, the meaning that is conferred through the tears can only be melancholy; there is no possibility of meaningful optimism.

151 "Ach, nur dem halbgetrockneten Auge/Wie öde, wie tot die Welt ihm erscheint". 


\section{Reichardt's version}

Reichardt's setting of Wonne der Wehmut reads the poem in a characteristically Gottschedian way: its form is strophic, it elevates the melody, and it elaborates a single affect throughout. Perhaps most striking, however, is its relationship to the poetic affect. While Goethe's poem sets up a solitary narrator who creates meaning out of suffering, Reichardt's setting enacts a domestication of that suffering. This sense of familiarity comes out of the application of Gottsched's principles: its continuity of a single affect comes from prolonged repetition in multiple musical domains, including melody and rhythm, which quickly constructs a sense of familiarity; the clear boundaries of the repeating strophic form are maintained through prepared half and authentic cadences; the major tonality and cyclical triple time add to its friendly collegiality.

This comfortable affect, however, is somewhat balanced by musical features which help to focus the poem's sense of suffering. The repeated rhythmic cells make use of a sighing motive and include many appoggiaturas, and at "wie öde" Reichardt tonicizes c minor through a fully diminished chord. Both of these add a slight sense of nervousness, or at least a touch of nostalgia, to this otherwise pleasant song.

\section{Beethoven's version}

Beethoven's “Wonne der Wehmut” presents a musical persona whose sorrow transforms into fear and then resignation when the poem mentions the dead-seeming world. The sudden change in affect at this moment colors the rest of the song, turning what initially is an outpouring of sweet melancholy into ambivalence between hope and despair. 
The song speaks initially of a sweet melancholy in various ways: the major tonality; the vocal skips with appoggiaturas; the text-painted tears in the accompaniment. The opening four measures presents a half period, which immediately begins to repeat as if to complete a full period. In a moment of foreshadowing as the phrase begins again, the accompaniment repeats the melody from the beginning while the voice adopts a rhythmic drone during the text-painted tears.

The keyboard replaces the voice at the outset of the consequent; the voice sings on a drone while the accompaniment plays the tears. At this moment, the right hand expresses the immediate feelings of the singer, and this technique, which returns in a few measures, gives a new role to the newly prominent accompaniment. The consequent is interrupted at "Ach nur", when the vocal melody comes in a half measure early and takes the place of the accompanimental tears. The phrase interruption continues on the other end, too; rather than cadence at "öde," it is extended with a surprise dominant harmony.

Indications of extreme unrest abound during the unexpected elongation of the phrase: the surprise dominant becomes a dark parallel tonic minor at "tot" before descending and decrescendoing into a forlorn A dominant seventh chord by "erscheint"; chromatic harmony suddenly abounds; the accompanimental texture thickens, and each harmony receives a sforzando; the voice leaps upward by a major sixth to an appoggiatura, by far its largest interval. The voice then drones on the minor third of the parallel minor harmony as the accompaniment descends. By “erscheint," passion has subsided into resignation

For the section from "öde" to "erscheint," the accompaniment has done the majority of the affective work. The droning vocal drone indicates a withdrawal into oneself; the keyboard expresses the workings of the mind. After "erscheint," the noodling sixteenth notes in the right 
hand suggest hope, and in the remainder of the song the voice and keyboard work together once again.

\section{Schubert's version}

Schubert's Wonne der Wehmut expresses melancholy through constraint. There is no pleasure here; instead, the constraint signifies nervousness, which crystallizes into debilitating fear at a single word. The minor mode, a limited range, and rhythmic sputtering all enhance the nervous feeling.

The song uses a range of techniques to signify secrecy and containment. A claustrophobic effect is generated through the use of a compact range in both melody and accompaniment. The melody extends only over the interval of a seventh, and the accompaniment spans several measures before the bass moves more than a single half-step. Both melody and accompaniment use mostly stepwise motion, a compositional choice that furthers the sense of constraint. The rhythm doubts itself from the beginning, moving quickly to the second half of each measure before pausing awkwardly. It finds some semblance of regularity in the hocketing accompaniment in the fifth measure, but this sliver of confidence only results in a questioning half cadence, leading straight back to the opening figuration.

The music enacts Goethe's lonely dialogue with oneself; this musical persona twice relinquishes self-control at "unglücklicker," both times revealing an unconscious presence. In these instances a sudden increase in the dynamic marking and chromatic harmonic shift signify the loss of control; the first resolution brings a shaky VII chord, while after the second moment, the more secure tonic is sought through an intervening harmony and is quickly found along with a quieter dynamic. 
There is nothing formally new in this song; its structure is identical to Reichardt's. The ABA' framework, with the half cadence on the dominant at the end of the B section and the subsequent repetition of the initial melodic line, are all typical of strophic Lieder. The content of the song and its attitude toward the text, however, shows trepidation and fear of unhappy love, and reveals a sense of doubt.

Despite their differences, then, both Beethoven's and Schubert's settings express nervousness, doubt, insecurity, fear, and a split self. These two composers thus take a different, Romantic approach to Wonne der Wehmut than Reichardt, whose comfortable and familiar setting places him in the optimistic Enlightenment.

\section{Sehnsucht (Was zieht mir das herz so?)}

Goethe's poem Sehnsucht (Was zieht mir das Herz so?) exemplifies his dramatic lyric poetry. The shifting emotions of an individual are at the heart of the narrative, in which the narrator transforms into a bird; discovers and sings to his beloved; transforms again into a star, lies at the feet of his beloved, and there finds happiness. The emotions of longing are continually changing here: longing for communion with nature; longing for the beloved; longing for eternal happiness. The joy of the final stanza is at odds with the poem's earlier anxiety and trepidation.

\section{Reichardt's version}

Reichardt's song, marked Sehnsuchtsvoll, passes by comfortably and amicably, with an outpouring of nostalgic emotion that is always neatly contained. The strophic form repeats after twenty measures of two phrases — one eight-measure modulating sentence that cadences on the dominant, and a twelve-measure period with a deceptive cadence after the first two phrase 
sections. Each phrase ends with a predictable cadence, every four measures are set to a line of the poem, and the final line of each stanza repeats after the deceptive cadence.

In its strophic structure, then, this song suggests containment, clarity, predictability and therefore a certain comfort. It bears a relation to its text similar to those of Reichardt's "Wonne der Wehmut" and Mozart's "Ich würd' auf meinem Pfad." In all of these, the suffering is highly bounded by both the musical and the poetic forms, such that even the wildest sense of despair expressed in each is mannered, gentlemanly, and sociable. Recall the line from Mozart's "Ich würd' auf meinem Pfad" that reminds the audience that one should suffer silently in polite company.

This sense is borne out by the form and content of Reichardt's music; the four-square phrases and neatly rhyming cadences are the main carriers of this message, and the single outlier to this politeness is clearly contained and well bounded within the form. The exceptional moment comes on the second beat of measure fourteen, at "hinuber" (Ex. ???). Before this moment, the song establishes a pattern of harmonic rhythms that change once every measure along with a pickup note in the left hand. The "hinuber" moment disrupts this pattern, and the dissonant, diminished juxtaposed harmonies highlights the presence of the disturbance. The jarring effect of a second-beat emphasis after thirteen measures of first-and-third beat emphases is strong, and almost brings the song to a standstill.

This and the next measure are the only ones with a different harmony on each beat, sources of energy that enable the song to move forward to its deceptive cadence. The sense of repose in the previous music is disrupted at this moment, canceling out the possibility of the song's immediate closure. Instead, it takes a more predictable phrase to finish the song. Despite 
the presence of this interrupted ending, there is never any question that the phrase will fail to close: the melodic rhythm is never interrupted, the accompaniment does not stop its triplet eighth notes, and even the surprising diminished harmony is immediately resolved to a more stable dominant seventh on the third beat.

The disruption at measure fourteen is not tied to any particular word or phrase; instead, it serves an instance of special emotion that embodies the sense of the whole poem. Thus, Reichardt maintains both strophic form and affective unity within the song while also inserting a moment of special tenderness.

\section{Beethoven's version}

Like his other settings, Beethoven writes his Was Zieht mir setting in stylistic and formal contrast from Reichardt's; also like the other settings, the song's greatest difference lies in its interpretation of the poetry. Instead of Reichardt's expansive yet contained expressivity, Beethoven communicates anxiety, trepidation, and nervousness. Several other factors establish the nervous mood: the accompaniment is more technically demanding than Reichardt's; the song uses a minor key; and it is set in a quick compound duple meter.

Anxiety is communicated from the first note. Because it arrives alone and is held for a relatively long time, the first note conveys an opacity of rhythm and key, the uncertainty of which is extended through the first two measures until the entrance of the voice. Without harmony, the winding, stepwise line reveals little about a possible key context, the only impLied harmony coming in the second measure in the form of two melodic skips and a leap. Even these, though, are of little help, forming as they do a diminished triad, whose associated key could be, at this point, either $\mathrm{d}$ major or $\mathrm{b}$ minor. 
The indications helping to establish key that are usually provided by meter are of little help here either. The fast, duple, compound meter that is so unusual for song is combined with a long first note and running sixteenths afterward, the effect of which is to mask the downbeats. Even if a listener is able to successfully decode the meter from the rhythms of the first measure, this provides little help as to the establishment of the key. Actually, the combination of the first two downbeat notes - F sharp in the first measure and C sharp in the second - obscure the key and instead point falsely toward an F sharp minor tonality. Finally, the swiftly changing direction and the quick rhythm of the single melodic line contributes to the uncertain, nervous mood in this opening gesture.

All of this uncertainty at the beginning of the song engenders a rather frightening experience, especially as compared to the first few measures of Reichardt's amicable setting. After these first few measures, the nervousness is transferred to the vocal line. The singing line consists of leaps of fourths, fifths, and sixths, a disconnected line whose tension is enhanced by the tense tightness of its fast, unchanging eighth-note rhythm.

As the vocal line shifts from these leaps to a legato stepwise motion and the harmony tonicizes D major, the anxiety of the opening quickly and rather suddenly becomes hopeful. But as soon as d major is tonicized, there is an immediate retraction and reversion back to b minor. This regression is paired along with a ritardando and a decrescendo, which ultimately cadences on a b minor first inversion chord. Finally, a kind of middle ground is reached between the hope of the D major and the lethargy of its juxtaposed b minor cadence, as the tempo is regained and a root position $\mathrm{b}$ minor cadence is decisively reached. 
This moment, however, does not complete the phrase. This last cadence is only half of a two-measure grouping, the latter a structure that pervades the prior ten measures. The effect of this rhetorically upbeat measure leaves the phrase harmonically complete but metrically incomplete, which instead directs the listener onward to the following measure.

Crucial to this song's structure, then, is measure 16 , which links the early cadence to the repetition of the initial $\mathrm{F}$ sharp. This measure provides a motivic link between the cadence of the previous measure and the long F sharp of the following measure. But while metrically it belongs to the previous measure, rhetorically it leads to the following measure. The crescendo along with the repetition of the three-note motive creates anticipation. This sense of anticipation is not only met, it is exceeded at the downbeat of measure 17, when the high F-sharp comes an eighth note early and interrupts the fragmentation of the cadential motive. Here, the cadence is less glossed over, underplayed, while the opening gesture is emphasized, underlined, reaffirmed. But this is the reaffirmation of an anxious, fundamentally insecure note, and thus feeling — a lonely, unharmonized dominant pitch of uncertain duration, floating in a musical abyss.

The modified strophic structure of Beethoven's song matches the drama of the poetry. With each new strophe, the accompaniment intensifies, until at last the parallel major meets with joy at the last stanza of poetry. The text communicates the narrator's transformation into a star; the happiness of the music at this point matches this ideal state. The anxiety of reality has been sublimated into an imagined joy.

\section{Schubert's Version}

Where Beethoven follows the drama of the poem with a modified-strophic setting, Schubert enacts a miniature scena, complete with recitatives. This "Sehnsucht" pulls Mozart's 
"Das Veilchen" inward; its dramatic scene depicts the inner emotions of the poetic persona. Schubert's version, like Beethoven's, is full of anxiety, but in a different sense. While Beethoven's is nervously anxious, Schubert's begins resigned and retreats into an imaginary world.

The keyboard introduction of this song colors the mood of its entirety. Though in a major key, the slow tempo, piano dynamic and sparseness of the single line immediately suggest contemplation; the contrapuntal texture implies nostalgia. This sentiment matches the first line of the text; from here, the text becomes more and more fantastical. The fanciful nature of the text is matched in Schubert's setting. To avoid melancholy, the narrator withdraws into an imaginary world with his beloved; the music follows. The text-painting that reoccurs throughout testifies to this imagined joy: the birdsong at "buschigten Wald;" the sun at "die scheidende Sonne;" the appearance of the star at "auf einmal erschein' ich." The non-reality of these instances is sadly ironic; their sudden, seemingly joyful major mode comes only as a result of unconvincing key changes.

This progression into an unreal world results in a cognitively dissonant conclusion; the final line of text professes happiness, a sentiment the music reinforces. Any reconciliation between this ending and the nostalgic, intensely sad introduction can only come from the realization that the song ends in a purely imagined state.

\section{Conclusion}

These analyses show the extent to which the Lied tradition had changed in Beethoven's hands. No longer recognizable as Enlightenment Lieder, his Goethe settings push the boundaries of form and content as a way to express the unique characteristics of the poet's works. In doing 
so, he breaks with the key precepts of Enlightenment song such as its melody supremacy, strophic form, and accompanimental simplicity. Although some of the features of his music are also present in the Enlightenment songs of Reichardt and Zelter, Beethoven's songs differ in significant ways.

Reichardt's songs express the new solitude of Goethe's poetry harmonically as he searched for ways to express the loneliness of Goethe's poetry. However, their strophic form forecloses any ability to initiate a musical narrative alongside Goethe's inner affective narrative. In contrast to the textural richness of Beethoven's settings, Reichardt's block chords can only add harmonic interest and reinforce a single affect.

With its modified strophic form, Zelter's setting of "Kennst du das Land" steps farther than Reichardt's from the Lied tradition; he retains Reichardt's foreign harmony, but also expresses Goethe's changing emotions through his use of the parallel minor in the second and third strophes. However, Zelter's accompaniment remains subordinate to the melody, and the modal change is the extent of the challenge to tradition; other than this detail, Zelter's affect is unified. Zelter's and Reichardt's songs remain within the confines of Enlightenment Lieder: Zelter's song maintains the tradition of keeping the melody in the foreground, thereby limiting the role of his accompaniment, and Reichardt continues to write strophic song.

Beethoven's songs adhere to none of the precepts of Enlightenment song; all three elevate the accompaniment to the equal of the singer and use a non-conventional form. He uses his freedom in these realms as a way to enhance the new features of Goethe's poetry: his accompaniments depict the solitude of the narrator; his forms enable changing affects, which in turn signify doubt and anxiety. 
This reading of Beethoven shares more with Schubert than with Reichardt and Zelter. Schubert's songs, like Beethoven's, express an anxiety about the old certainties: his "Wonne der Wehmut" communicates intense worry; his "Sehnsucht" only conveys joy when the narrator is transported to an ideal world. But Schubert's "Sehnsucht" goes further than Beethoven into the realm of the imaginary; its fictional joy comes almost immediately, whereas Beethoven only reaches that space in the final stanza.

The interpretations proposed by this chapter place Beethoven's songs in a new light; rather than an extension of the formal concerns of the Enlightenment Lied or the Classical style, these songs break convention to express new worldviews. 
Reichardt, "Kennst du das Land"
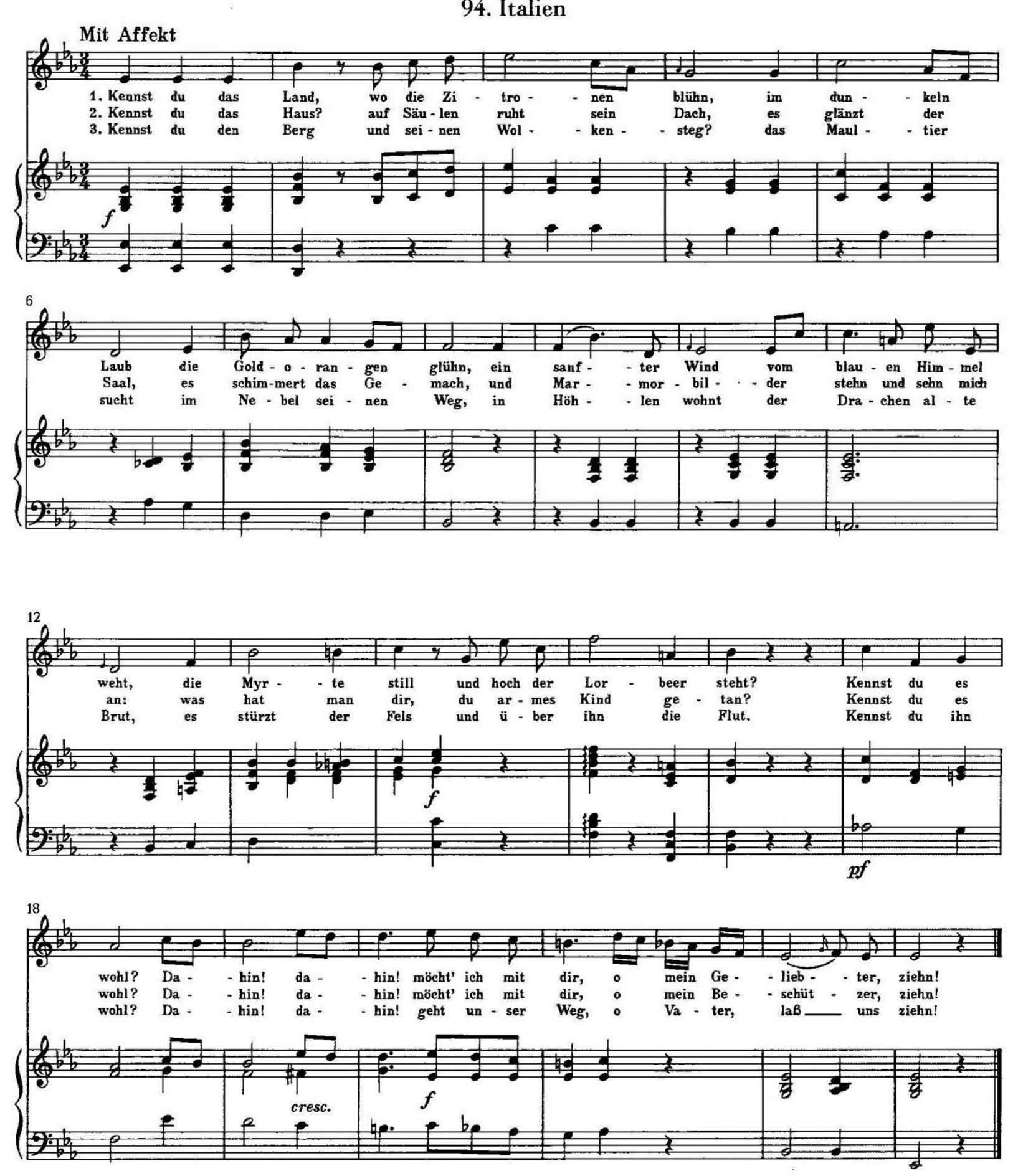
Zelter, "Kennst du das Land"

12.
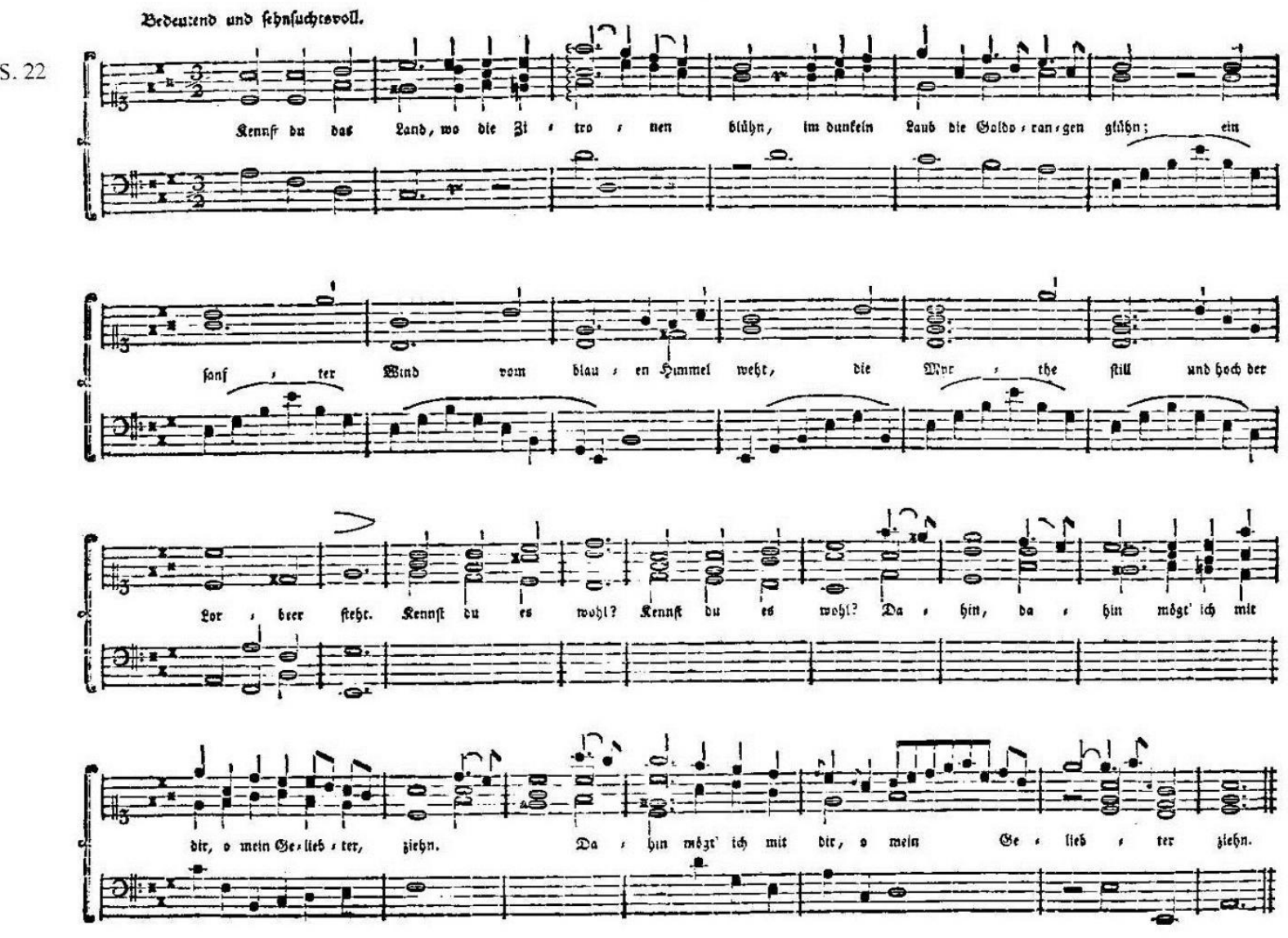
Zelter, "Kennst du das Land" Stanzas 2 and 3
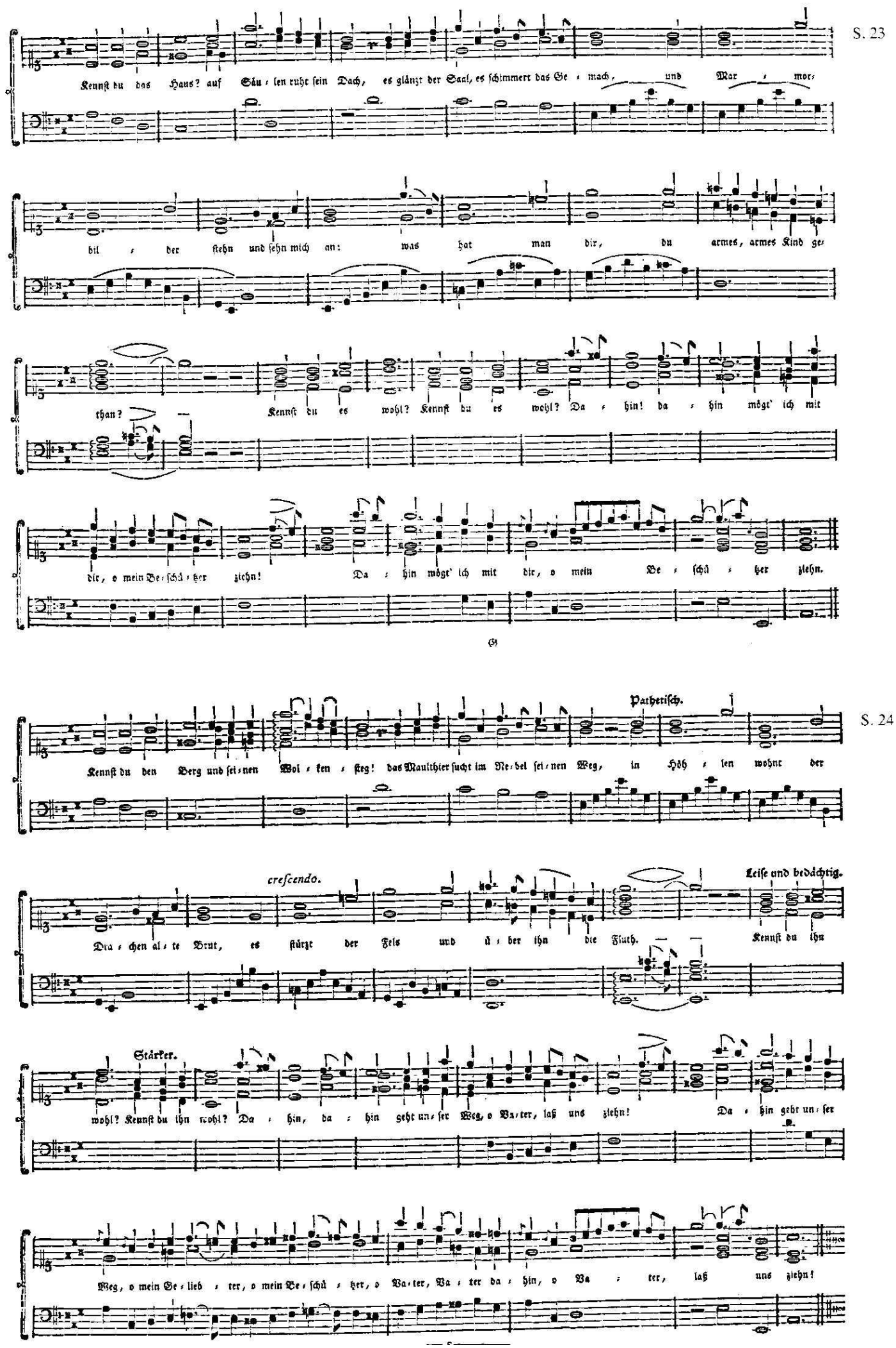
Beethoven, "Kennst du das Land"

(31) 1

\section{SECHS GESÄNGE \\ in Musik gesetzt rou \\ B. VAM BRBTIOVBD.}

Der Fürstin von Kinshy gewidmet.

Op. 75.
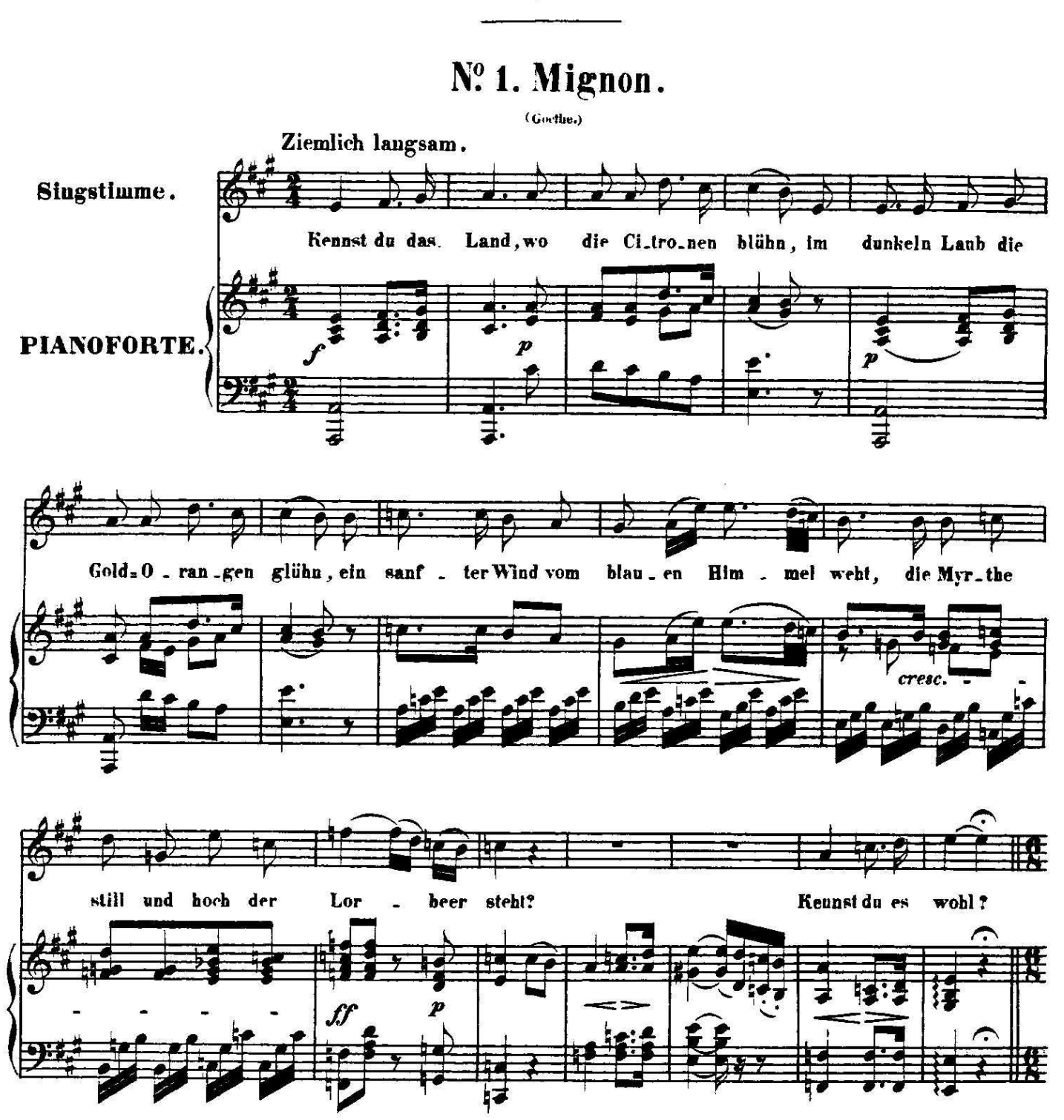
Beethoven, "Kennst du das Land" Stanza 2

2 (3:2)
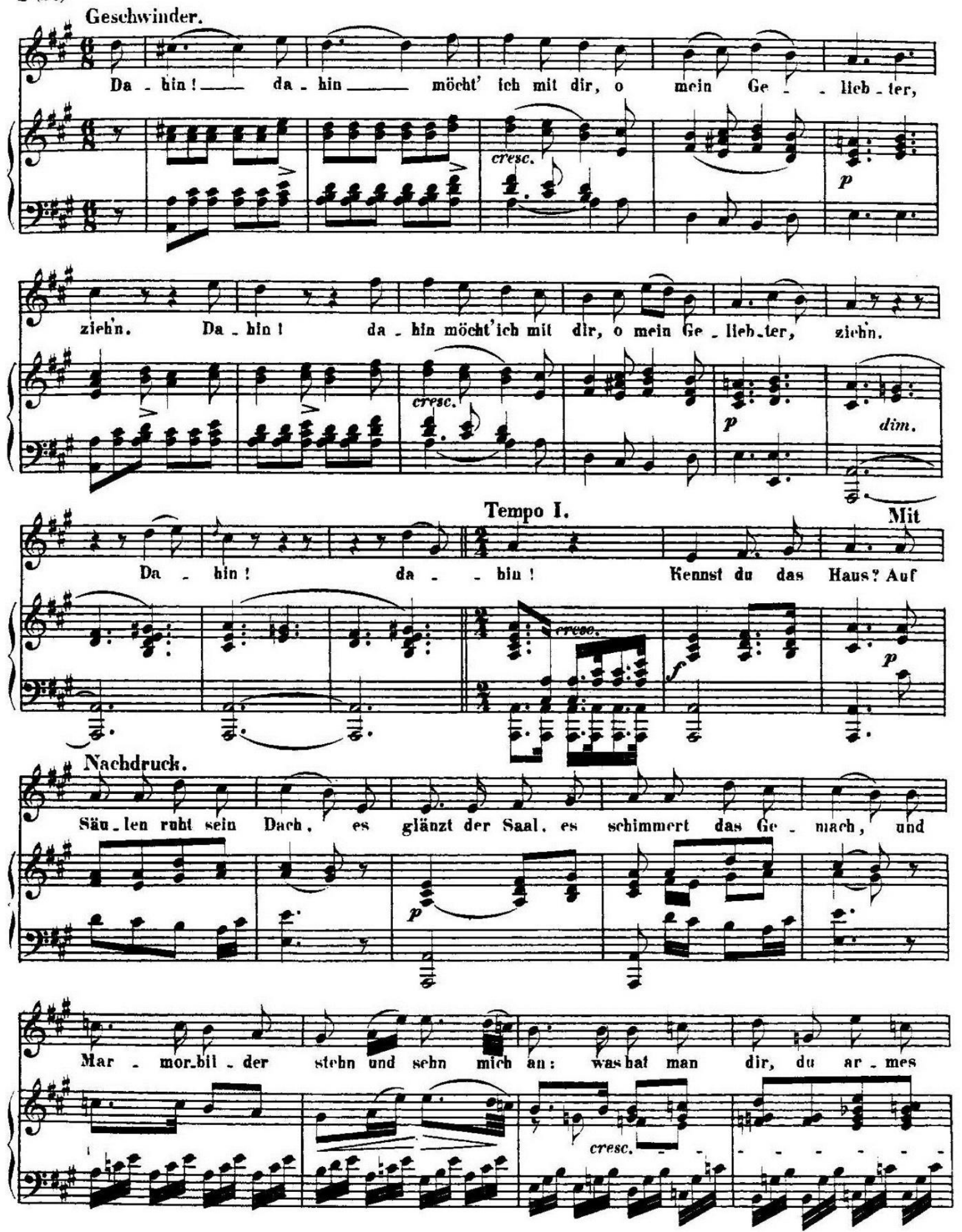
Beethoven, "Kennst du das Land" Stanza 3

4 (31)
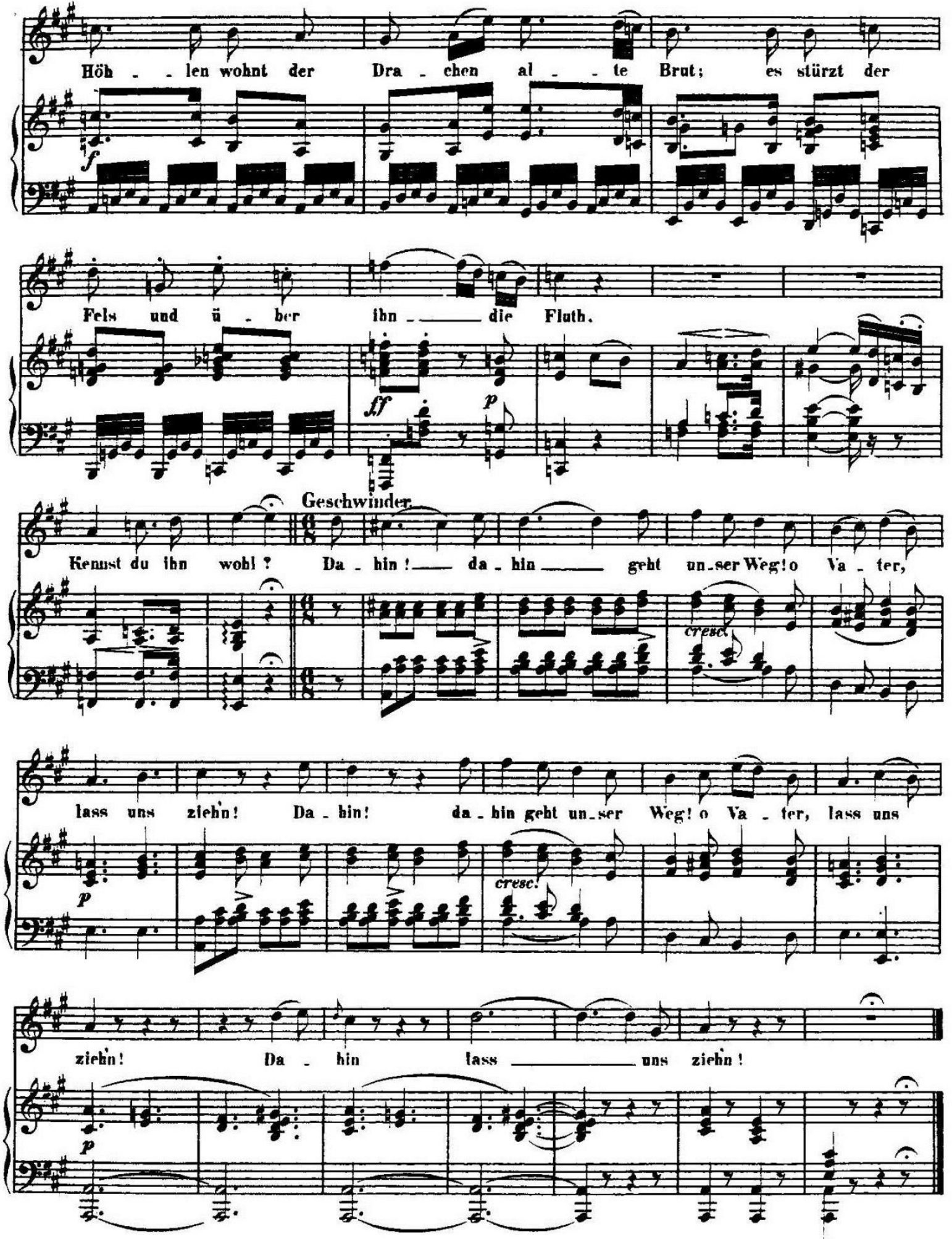
Schubert, "Kennst du das Land"

$$
\text { Mignon. }
$$

Aus Goethe's "Wilhelm Meister".

Für eine Singstimme mit Begleitung des Pianoforte

\section{FRANZ SCHUBERT.}
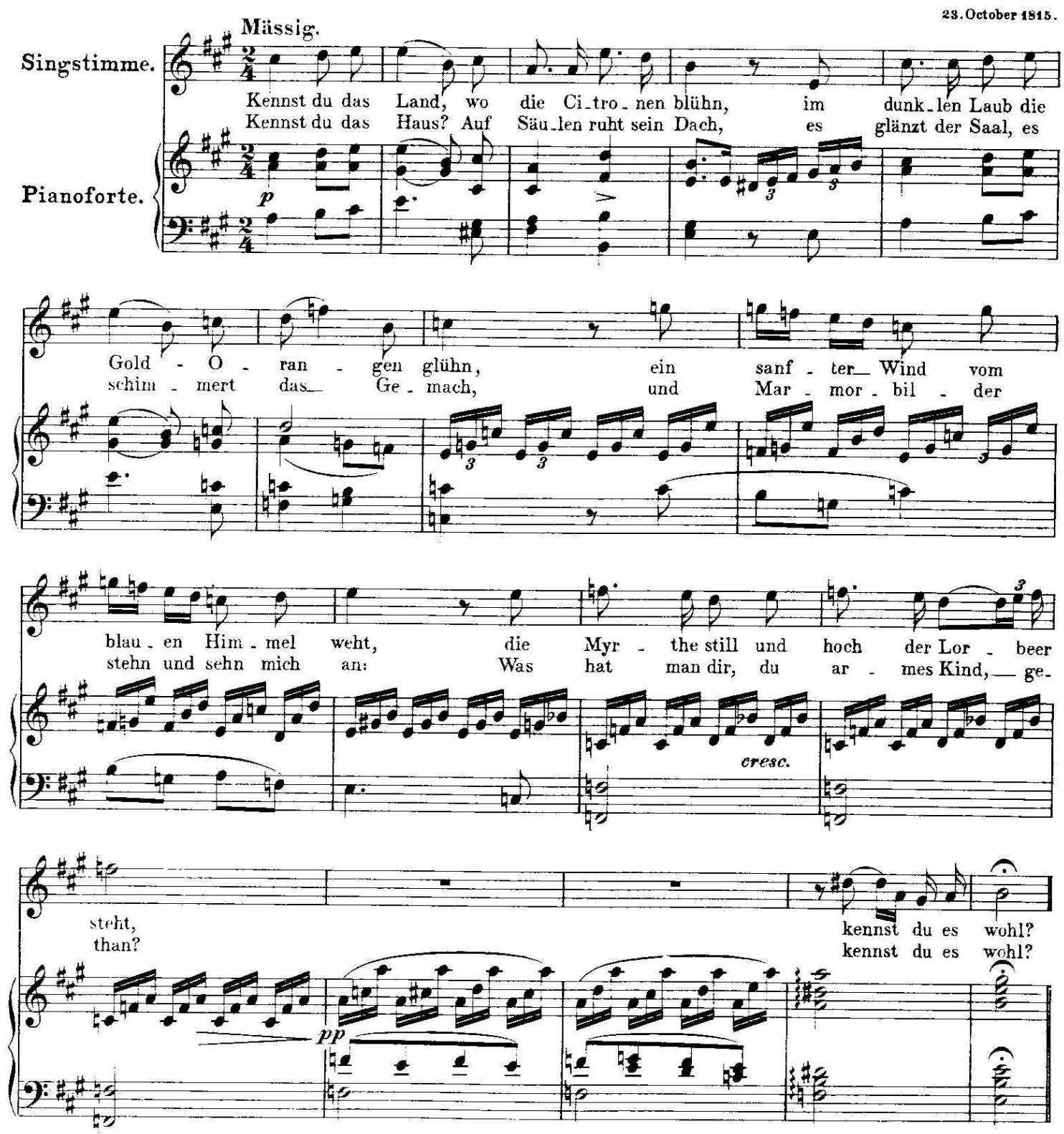
Schubert, "Kennst du das Land" "dahin!"

80
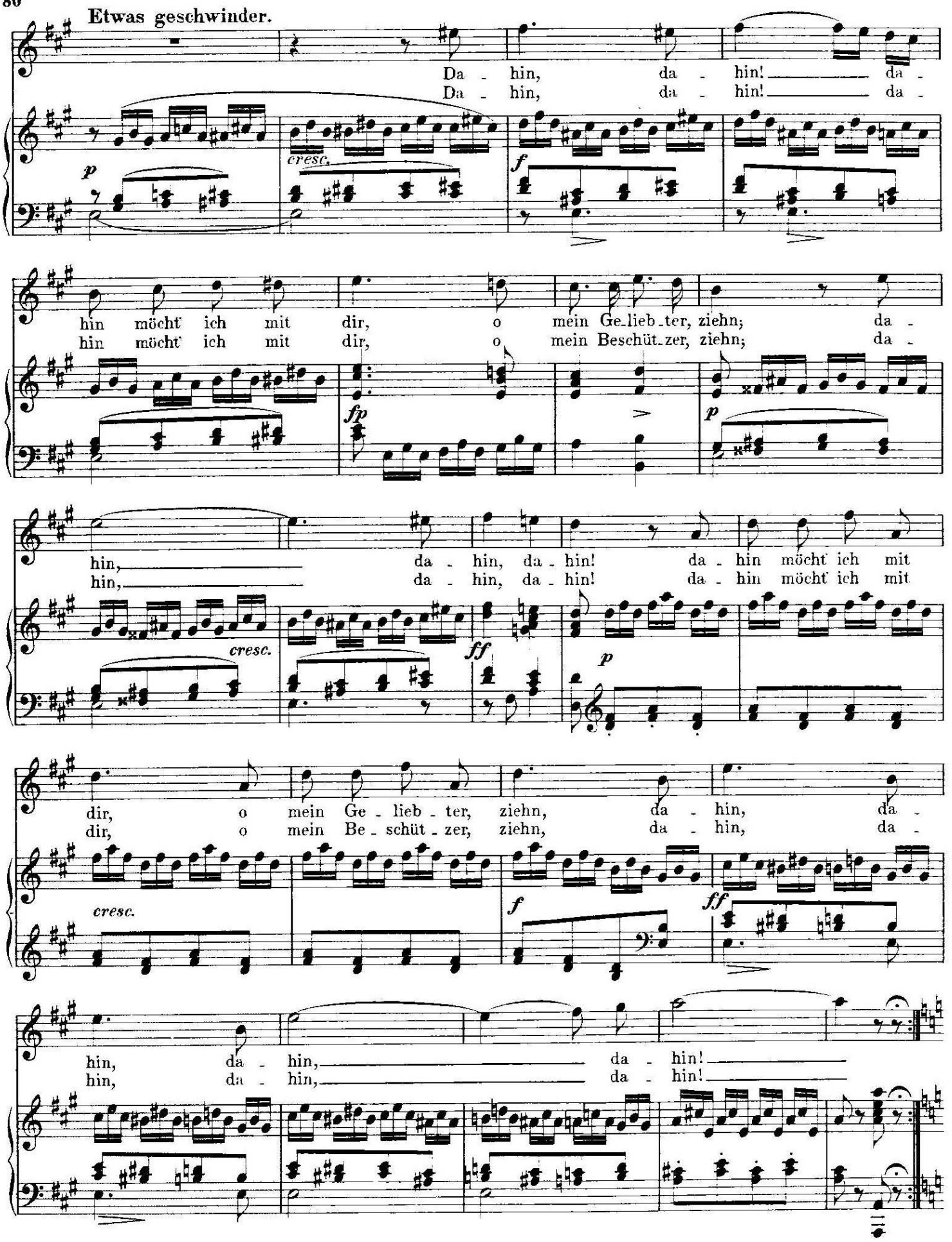
Schubert, "Kennst du das Land" Stanza 3

81
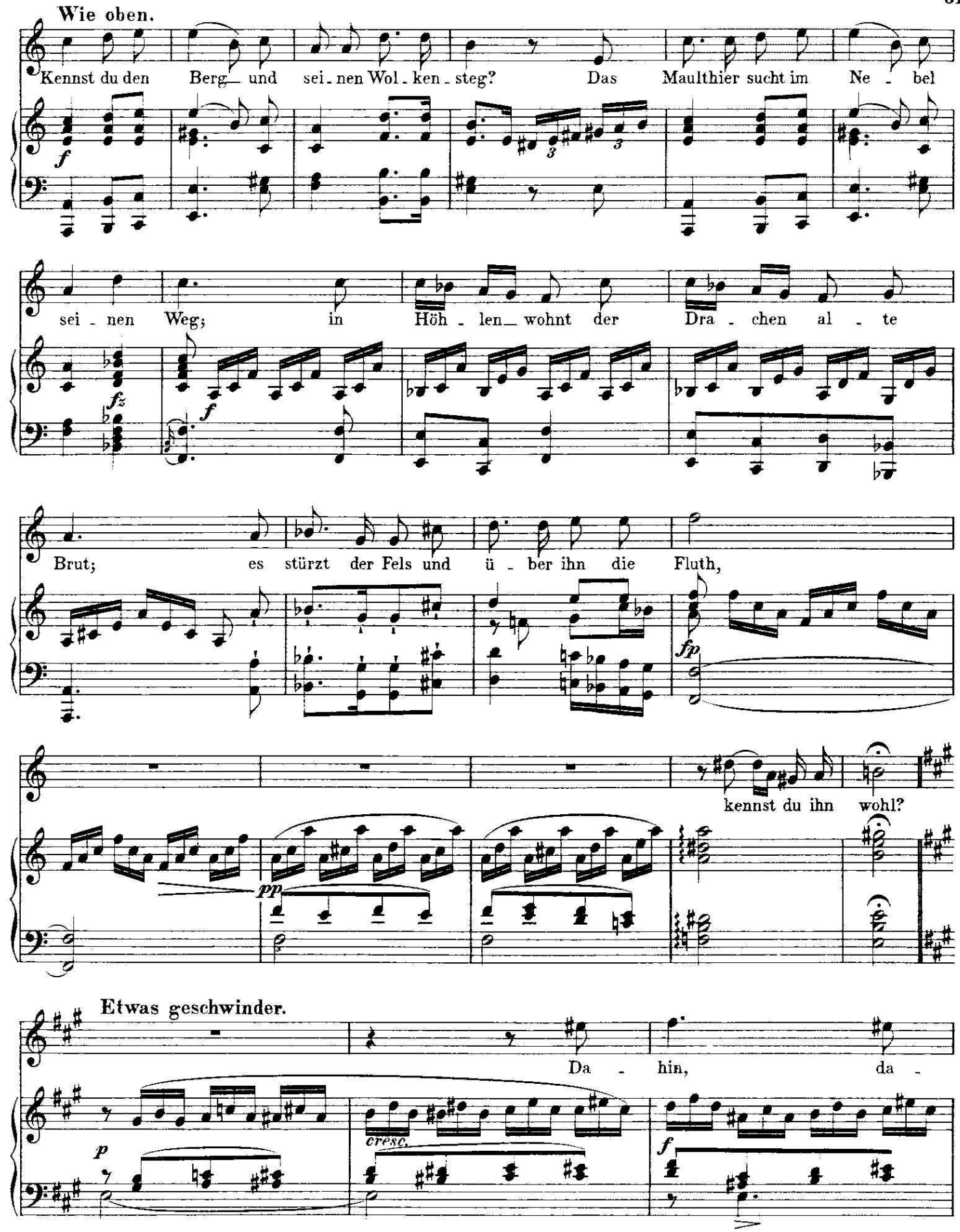


\section{Reichardt, "Wonne der Wehmut"}

\section{Wonne der Wehmut}

Langsam und innig
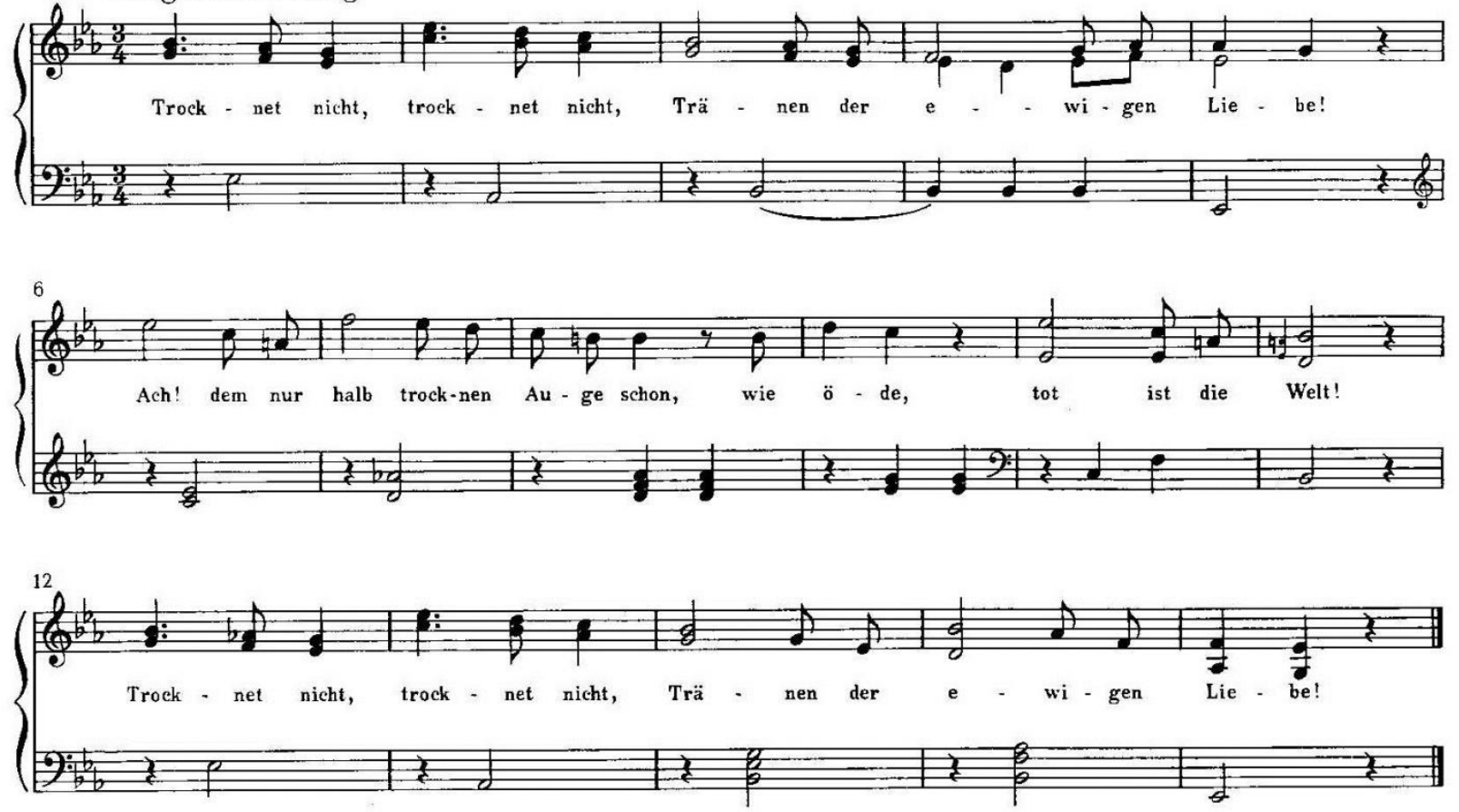
Beethoven, "Wonne der Wehmut" page 1

DREI GESÄNGE

(57) 1

(Gedichte von Goethe) in Musik gesetzt von

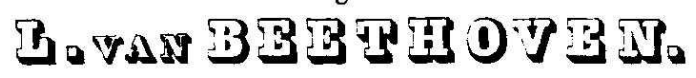

Der Fürstin ron Kinsky gewidmet.

Op. 83.

\section{No 1. Wonne der Wehmuth.}
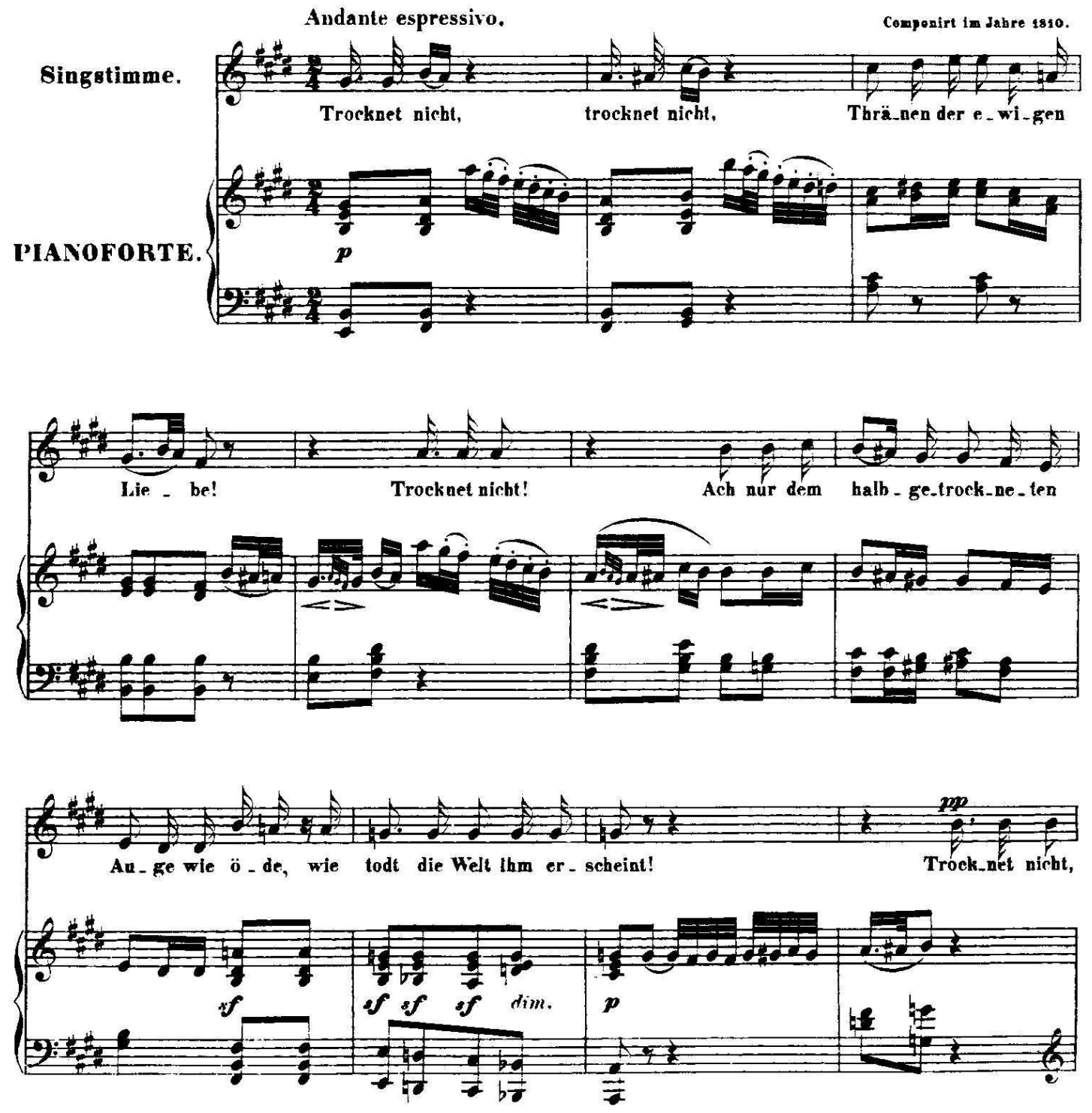
Beethoven, "Wonne der Wehmut" page 2

$2(58)$
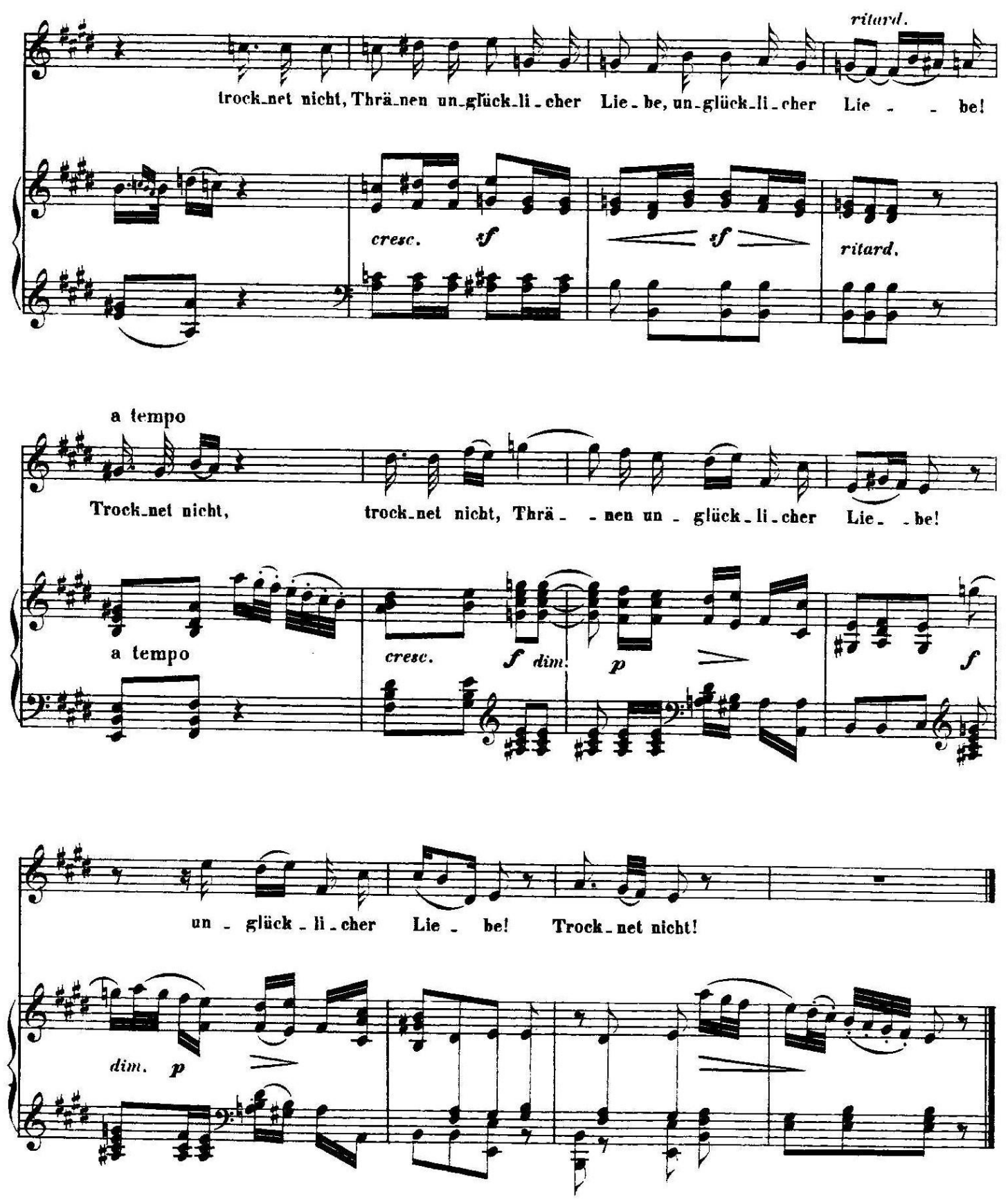
Schubert, "Wonne der Wehmut"

\title{
Wonne der Wehmuth.
}

\author{
Gedicht von J. W. v. Goethe.
}

Fïr eine Singstimme mit Begleitung des Pianoforte

\section{FRANZ SCHUBERT. \\ Erschienen als Op.115. No 2.}

Etwas geschwind.
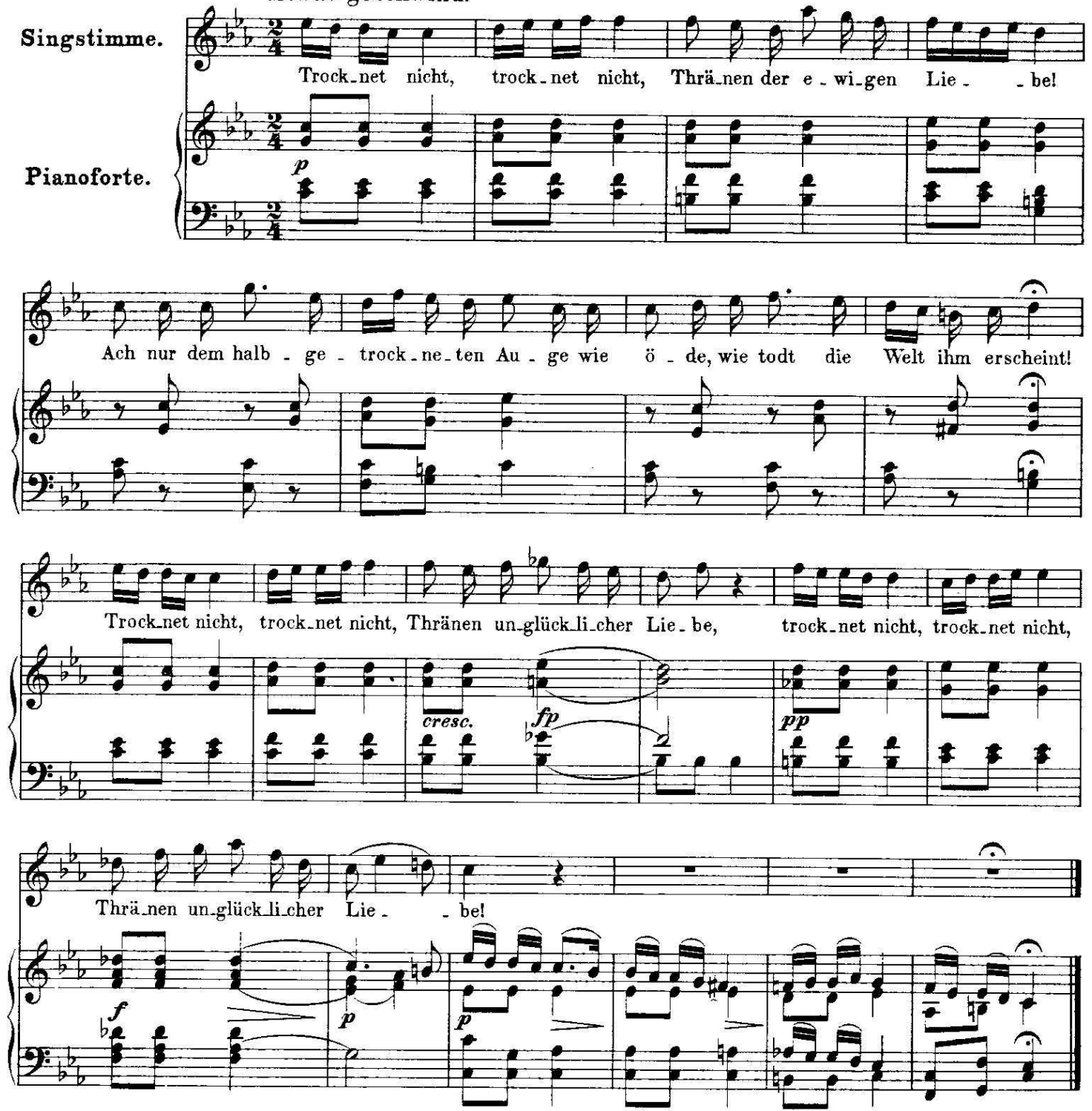
Reichardt, "Sehnsucht (Was zieht mir das Herz so?)"

40. Sehnsucht
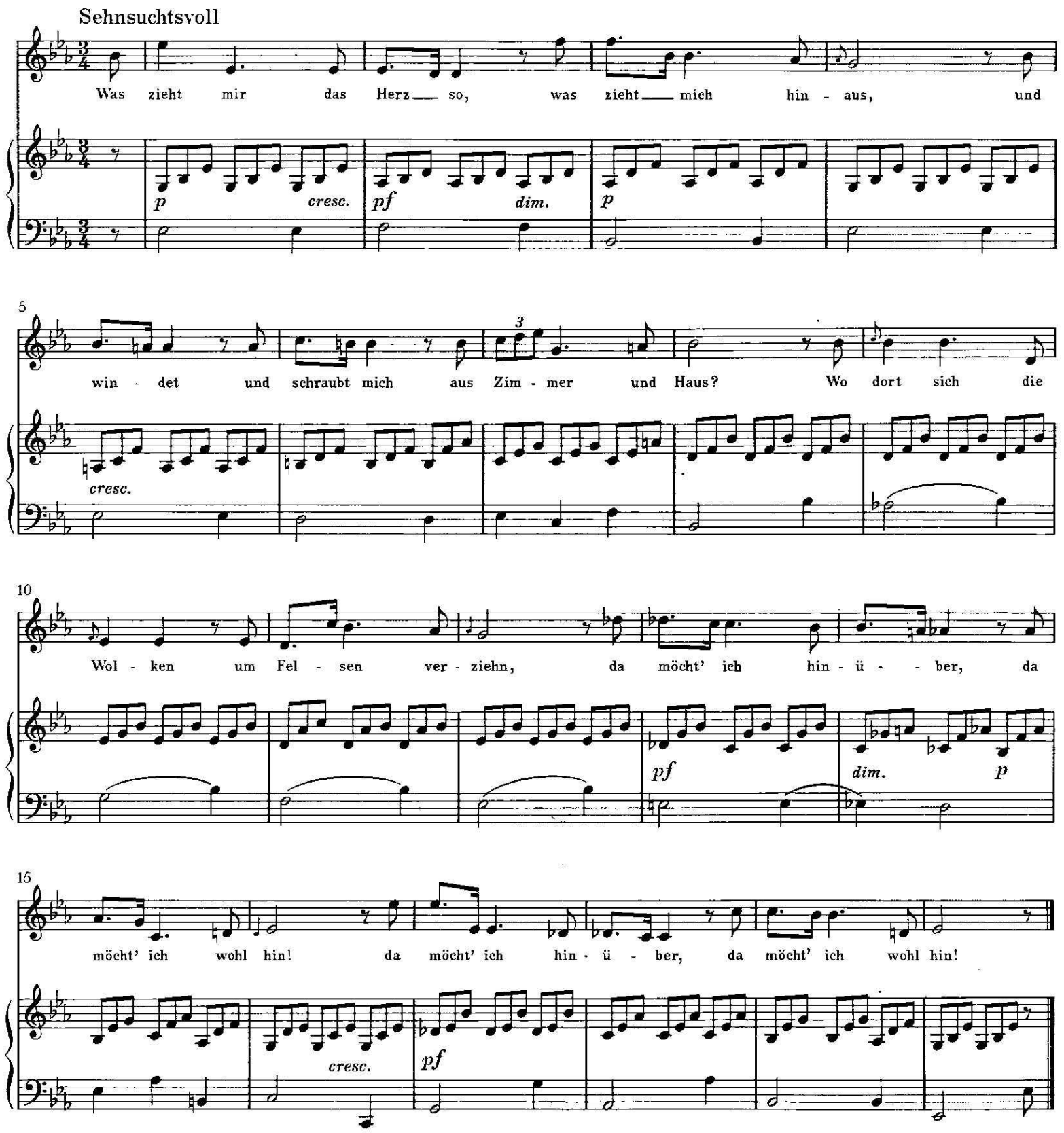

Nun wiegt sich der Raben Geselliger Flug,

Ich mische mich drunter Und folge dem Zug.

Und Berg und Gemäuer Umfittigen wir,

Sie weilet da drunten,

Ich spähe nach ihr.
Da kommt sie und wandelt,

Ich eile sobald,

Ein singender Vogel,

Zum buschigten Wald,

Sie weilet und horchet,

Und lächelt mit sich:

„Er singet so lieblich

Und singt es an mich."
Die scheidende Sonne

Verguldet die Höhn,

Die sinnende Schöne

Sie läßt es geschehn.

Sie wandelt am Bache

Die Wiesen entlang,

Und finster und finstrer

Umsehlingt sich der Gang.
Auf einmal erschein' ich Ein blinkender Stern.

"W as glänzet da droben? So nah und so fern ?cc

Und hast du mit Stannen Das Leuchten erblickt; Ich lieg dir zu FüBen,

$\mathrm{Da}$ bin ich beglückt! 
Beethoven, "Sehnsucht (Was zieht mir das Herz so?)"

(59) 8

\section{No 2. Sehnsucht.}
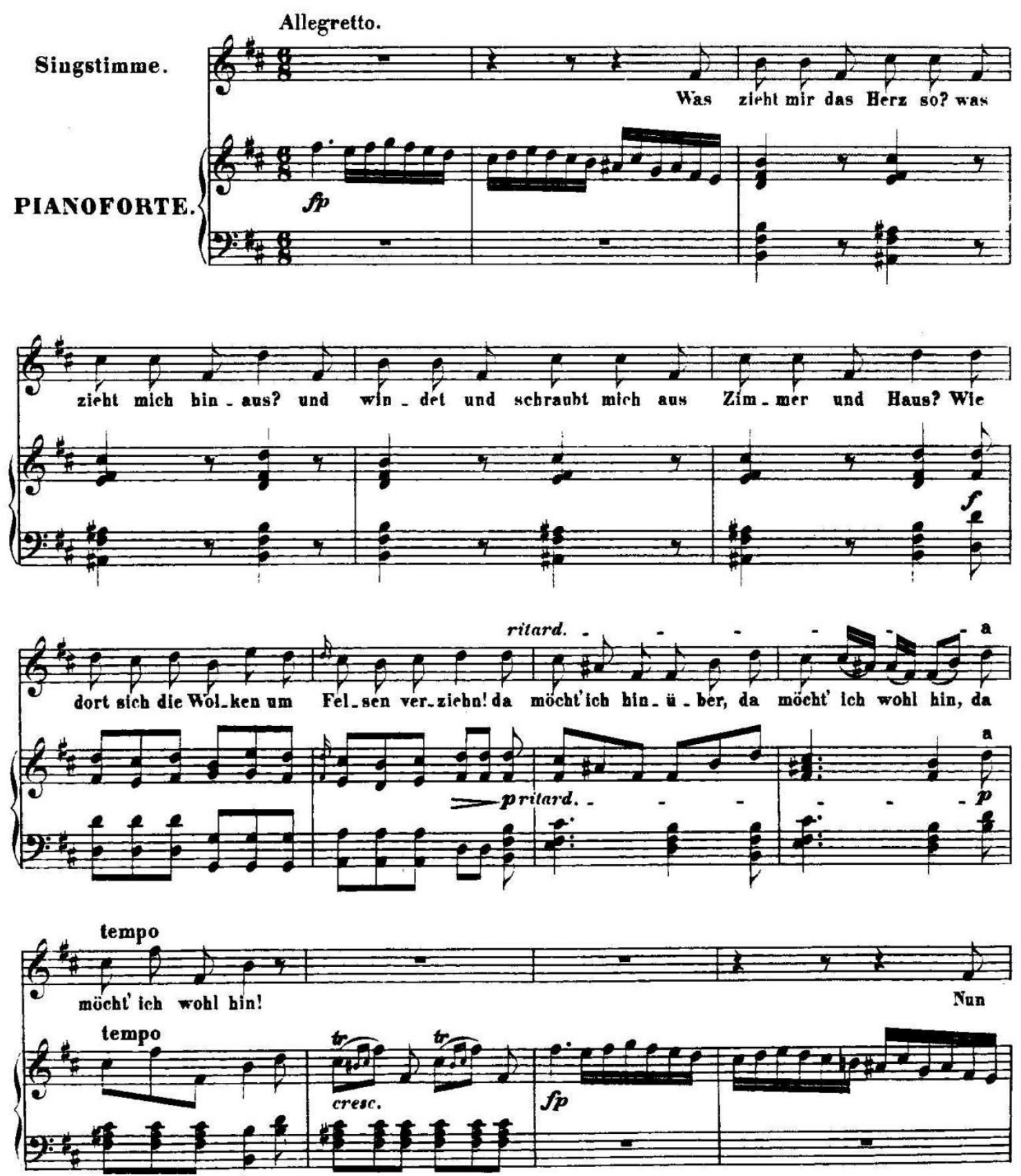
Beethoven, "Sehnsucht (Was zieht mir das Herz so?)" Stanzas 2 and 3

(60)
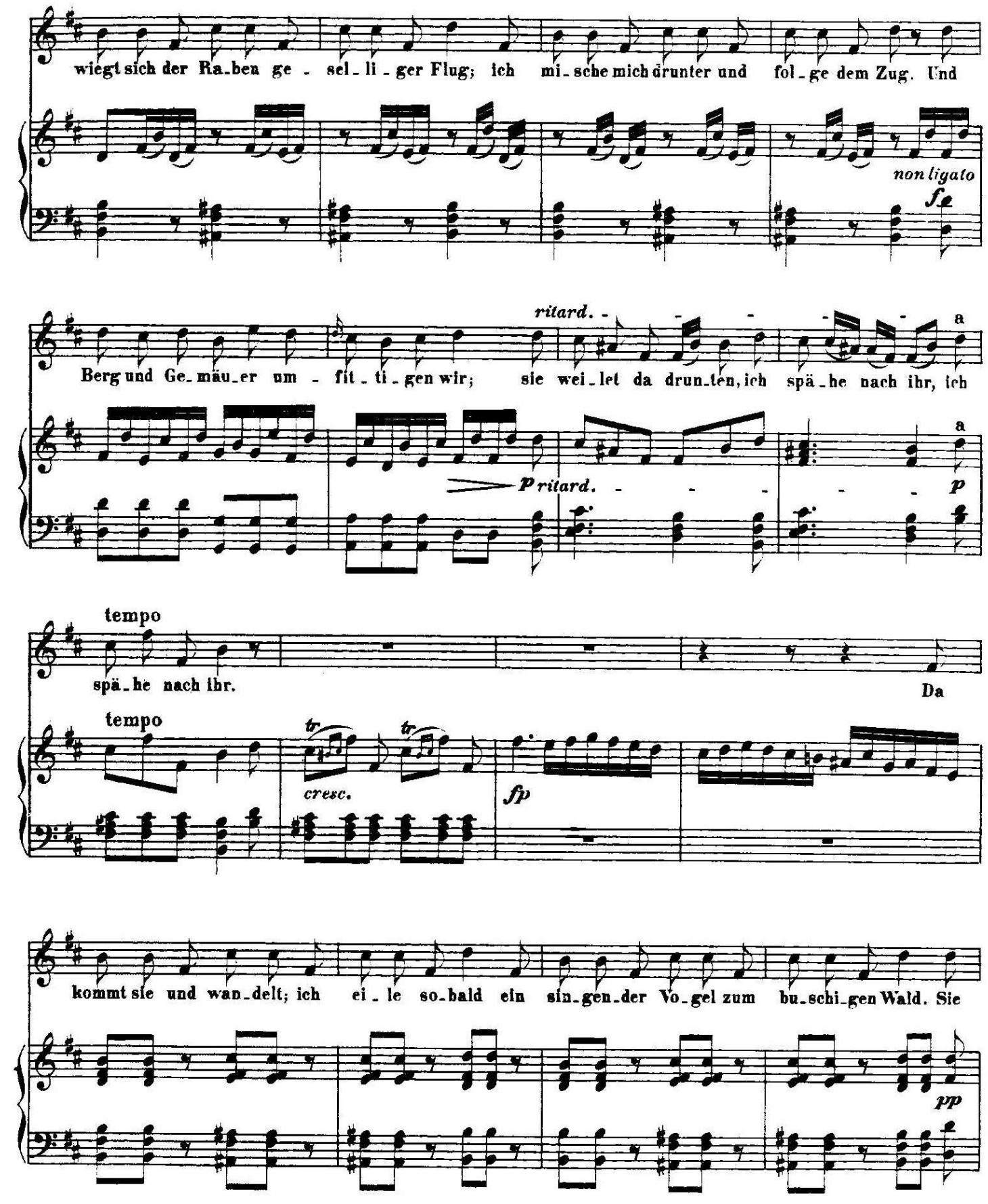
Beethoven, "Sehnsucht (Was zieht mir das Herz so?)" Stanzas 3 and 4
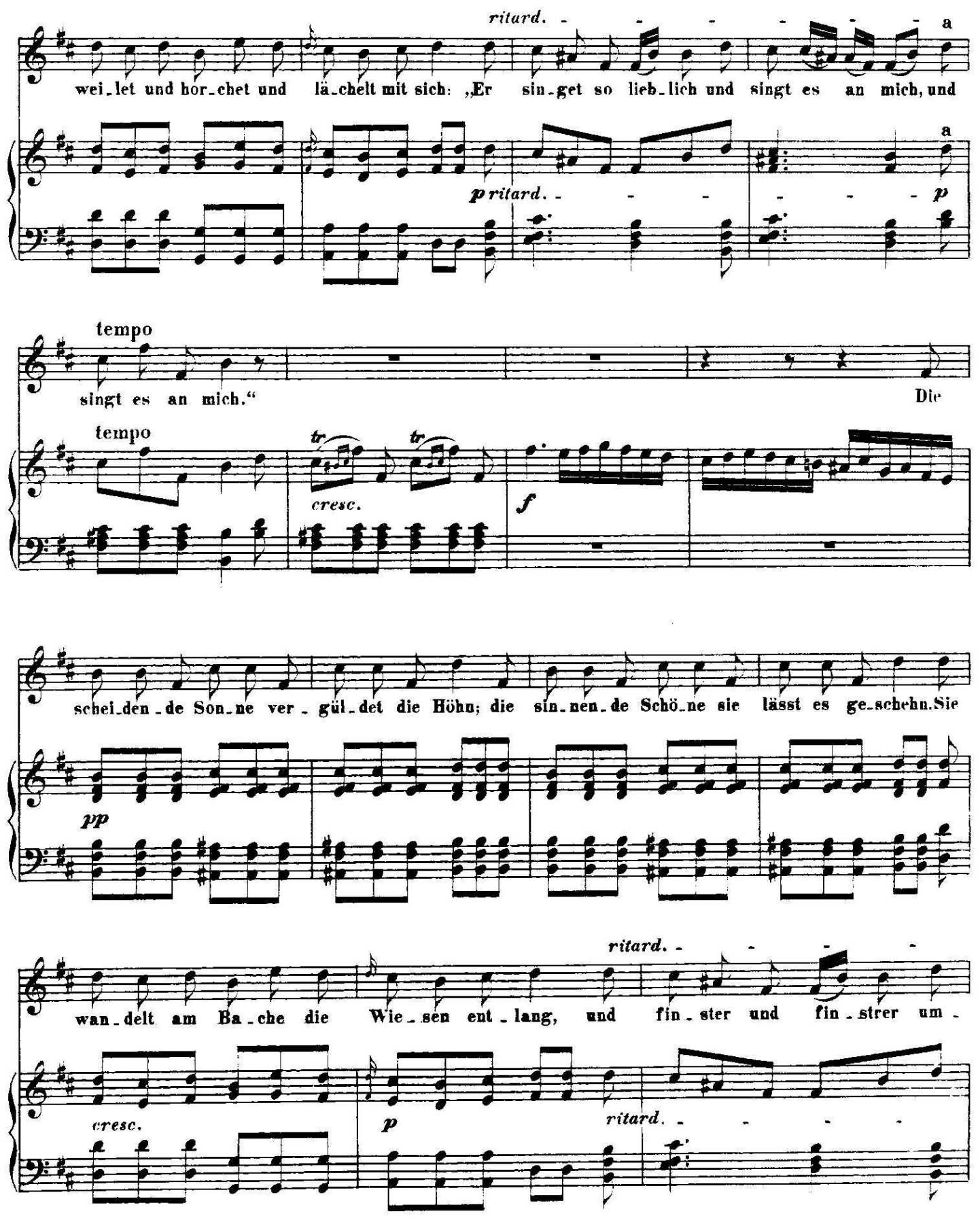
Beethoven, "Sehnsucht (Was zieht mir das Herz so?)" Stanzas 4 and 5

f(62)
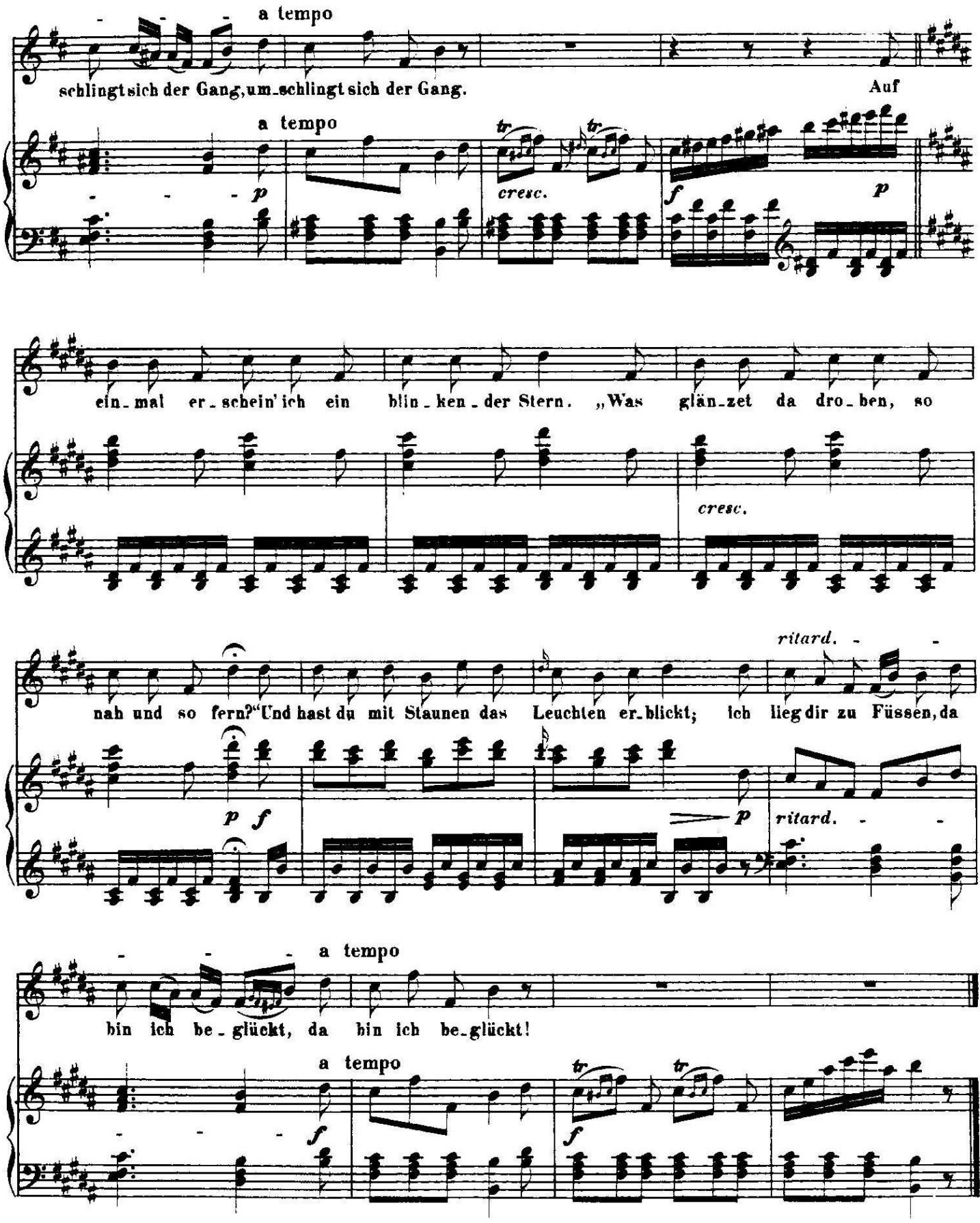
Schubert, "Sehnsucht (Was zieht mir das Herz so?)"

16

\author{
Sehnsucht.
}

Gedicht von J. W. v. Goethe.

Für eine Singstimme mit Begleitung des Pianoforte

componirt von

FRANZ SCHUBERT.
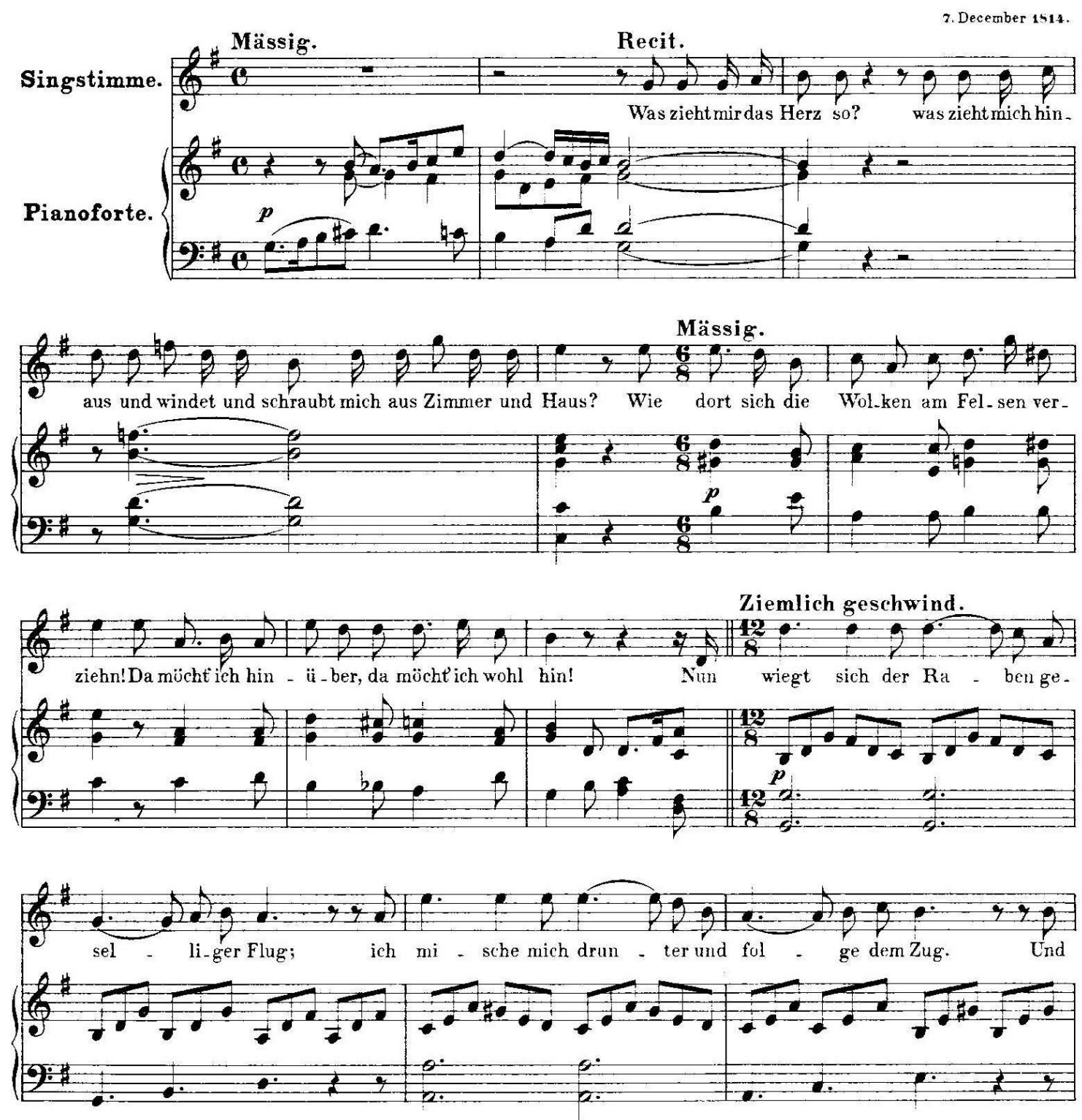
Schubert, "Sehnsucht (Was zieht mir das Herz so?)" Stanzas 2 and 3
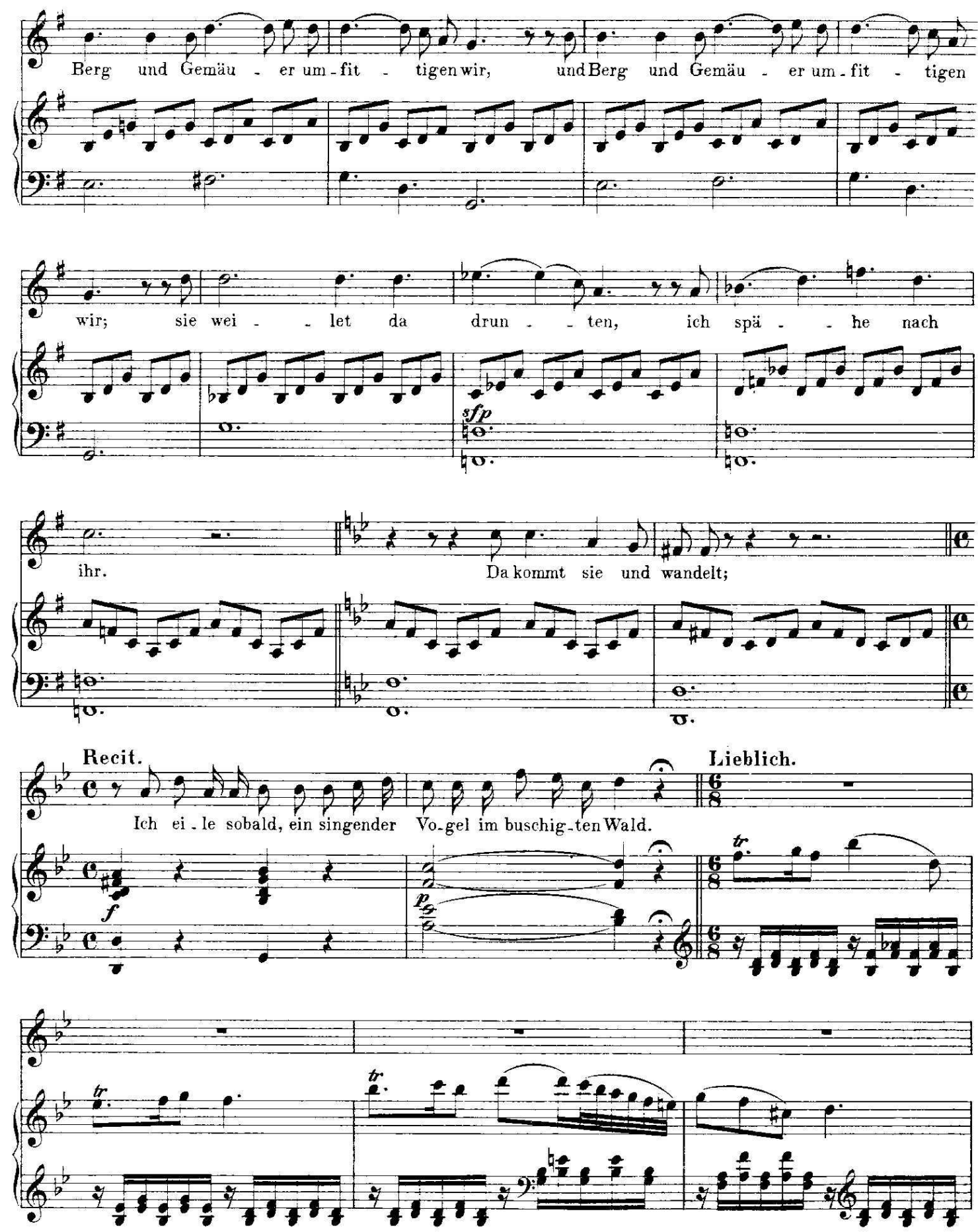
Schubert, "Sehnsucht (Was zieht mir das Herz so?)" Stanzas 3 and 4

18
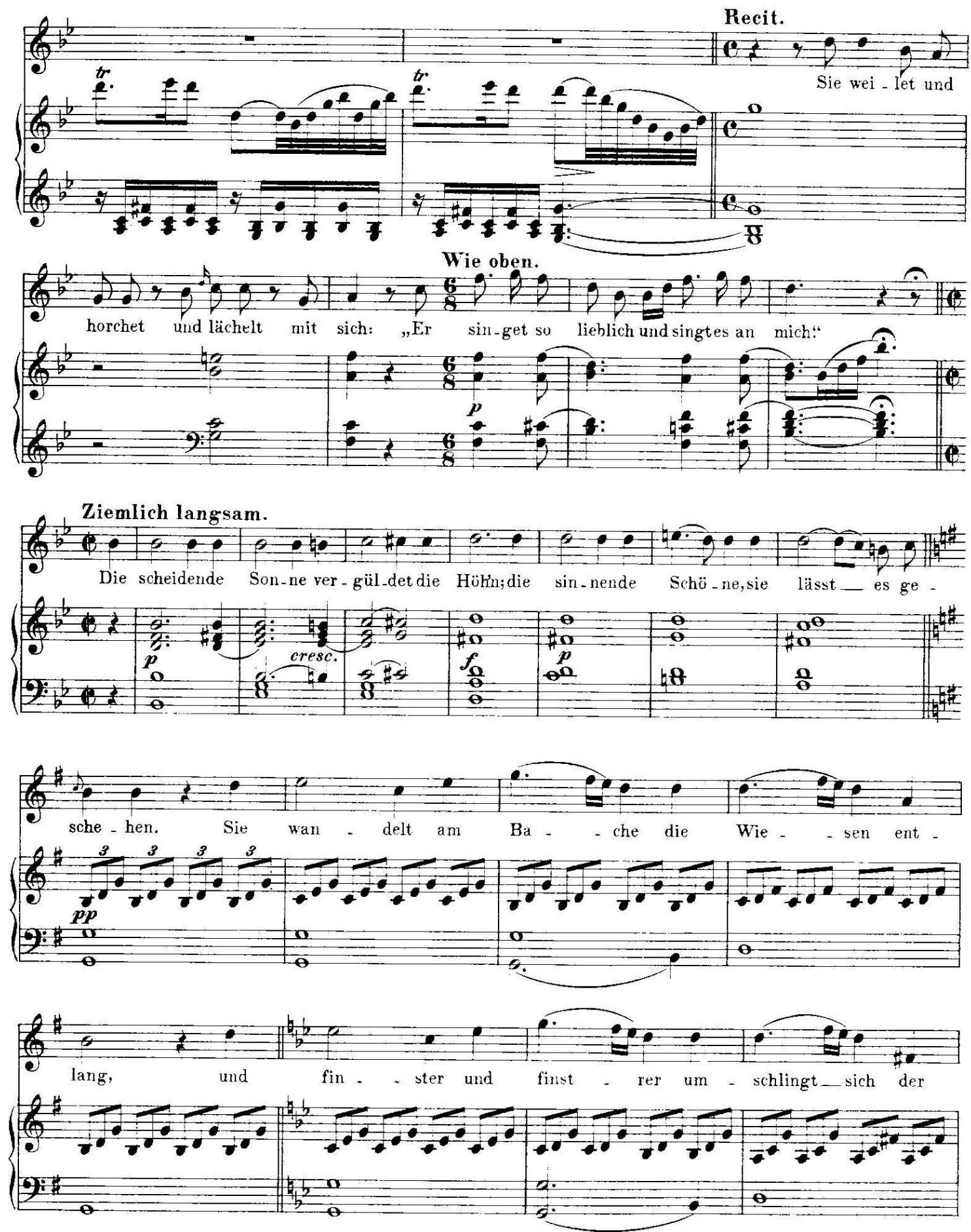
Schubert, "Sehnsucht (Was zieht mir das Herz so?)" Stanzas 4 and 5
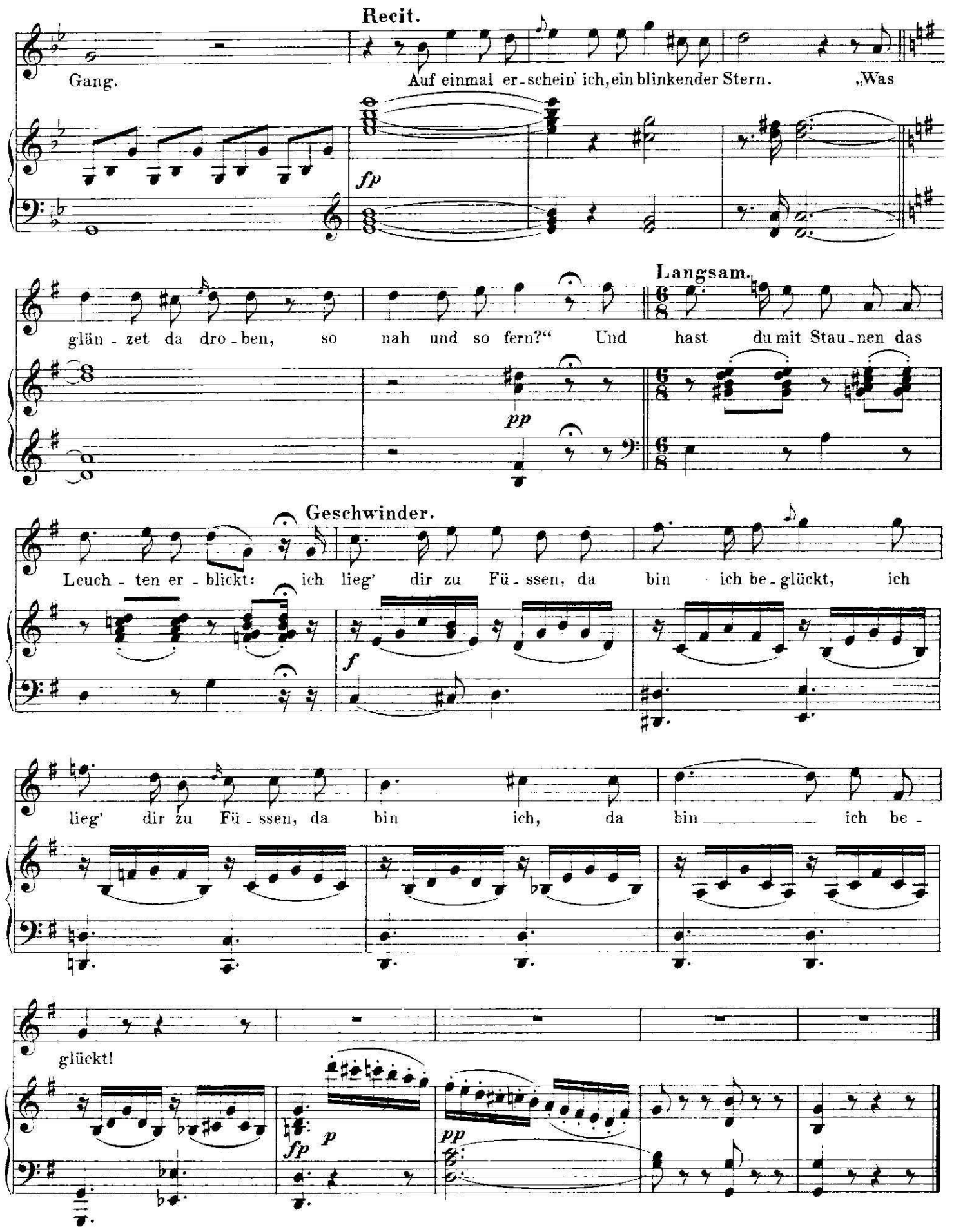


\section{Recordings of Beethoven's Piano Sonata Op. 10, No. 2 in Context: A Comparison of Playing Style and Changing Notions about Beethoven's Compositional Style}

This chapter explores how the changing image of Beethoven as a Classicist and a Romantic has affected the interpretation of his music through an examination of $20^{\text {th }}$ century recordings of his Piano Sonata Op. 10, No. 2. Before moving into a recording analysis, I will present the current approaches to analyzing the history of music recordings. As will become clear in the following paragraphs, a number of methodological and conceptual questions have yet to be settled in this new field. I follow the discussion of performance history literature with a discussion of the close kinship between the historiography of Beethoven's image and the history of performance of his music. Not only does this analysis show the significance of understanding the change in Beethoven narratives and interpretations over time, but it lends further credence to the problematic aspects of understanding Beethoven through the anachronistic labels of Romantic and Classical. By examining these recent images of Beethoven — present in both the writings and performances of the $20^{\text {th }}$ century - I further demonstrate the need to think about Beethoven through the lens of Early Romanticism.

\section{Philip and the Foundation of Recording Analysis}

Writing on the history of performance is still a young field, and many fundamental issues remain open to debate: How should we conceptualize the musical work given that the body of primary sources that constitutes this kind of research, namely, recordings, differs fundamentally from the traditional object of musicological study? What are potential avenues of study open to us with this body of evidence? In other words, to what kinds of questions can this evidence provide answers? What methodologies are useful for analyzing recordings, and to what extent 
can we import ideas and methods from score-based analysis? What is the relationship between scores and recordings, and how do recordings change our understanding of the ontology of music? If we continue to rely on score analysis, even when analyzing recordings, how do we explain what we cannot see on the page?

Commonly, musicologists construct style histories of performance similar to those of composition. Like all narrative histories, these turn to various forces, historical, psychological, and technological, in order to explain how performance practice has changed since the early twentieth century. Here I will trace some ideas about how performance has changed over time, and theories on the causes of such changes.

\section{Robert Philip's Early Recordings and Musical Style: Changing Tastes in Instrumental}

Performance, 1900-1950, published in 1992, has shaped much subsequent writing on the history of recordings. I will spend some time exploring it, and because my own analysis deals mostly with the use of rhythm in performance, focus on Philip's chapters on tempo variation and the use of rubato.

Philip's book traces large-scale stylistic changes evident from recordings in the first half of the twentieth century. He identifies three areas of variable style — rhythm, vibrato, and portamento - which he tracks over the course of the half century. Focusing on instrumental music, he further breaks down each component of performance style, tracing the changes for each in both recordings and in written commentaries on performance. One of Philip's major conclusions is that performers don't always do what they say, and that there is often a disconnect between writings about performance and recordings. ${ }^{152}$ The chapters on tempo, however, do not

\footnotetext{
${ }^{152}$ Robert Philip, Early Recordings and Musical Style: Changing Tastes in Instrumental Performance, 1900-1950 (Cambridge: Cambridge University Press, 1992): 2.
} 
bear out this assessment. Instead, there seems to be a strong correlation between the written word and the recorded performance in these chapters.

In the chapters on tempo, Philip builds a case for the proposition that an earlier flexibility of tempos within movements gave way to stricter interpretations after the Second World War. In writings on performance, conductors provide the major documentary information for Philip. Wagner, Von Bülow, and Mahler make the case for a degree of tempo flexibility that should match the emotion of the moment. Primarily, this consisted of speeding up during passionate phrases and slowing down at less energetic times. Later conductors changed the fashion in tempo flexibility; Philip cites Weingartner and Toscanini as the major figures who advocated for less variability of tempo within movements.

By timing tempos in recordings, Philip shows a trend toward less tempo variability on a large scale in recording after World War II. Some flexibility still exists, and while there are exceptions to the trend, Philip states that tempo flexibility in later recordings usually occurs when performers slow down in lyrical passages, not when they speed up in excited sections. This results in slower overall tempos, in addition to a smaller range of tempos. Philip attributes this trend to Toscanini, whose insistence on invariant tempos has remained important in subsequent playing as an influence on later performance practice.

Philip writes similarly about tempo rubato, showing how early recordings and writings from early twentieth-century practitioners such as Theodor Leschetitzky and Tobias Matthay use a metaphor between music and spoken rhetoric, emphasizing communicative effectiveness as a way to achieve expressive playing. Busoni, for example, wrote that "The bar-line is only for the eye. In playing, as in reading a poem, the scanning must be subordinate to the declamation: you 
must speak the piano."153 Matthay, among many others, preached balance in the use of rubato, pointing out that when time is taken for emphasis, it must be given back later to account for the loss. As Philip writes, "A number of writers...talk about rubato in terms of rhetoric, and the volatility and detailed emphasis of the style [of playing evident from the recordings] does suggest analogies with the stresses of speech." 154 Similarly, on the topic of flexibility of tempo, Philip writes that "Many writers from the end of the nineteenth century and the early years of the twentieth century recommend flexibility of tempo, and reject the idea that a piece of music should be played at a constant pace." This observation aligns with the high degree of tempo variability that Philip finds in many early recordings.

Before moving beyond Philip, it is important to understand the historical narrative which he constructs. In the introduction, he views the early twentieth century as a particularly important and dynamic time in the history of performance. By comparison, the earlier and later eras, the nineteenth century and post-World War II, respectively, were times in which performance changed little. It is not clear, however, why the rate of change in early twentieth-century performance practice should differ from that of the earlier and later periods. While we do have a recorded history that begins in the early twentieth century, and none for the preceding period, there does not seem to be any reason to assume that performance practice in the nineteenth century was any more unified or standardized than it was in the early twentieth century. And though later writers have made technological-causal arguments that support Philip's contention of a standardization of recordings after World War II, this argument has also been disputed. First, though, I explain how later writers have constructed narratives of stylistic change. Since Philip,

\footnotetext{
${ }^{153}$ Philip, 42.

${ }^{154}$ Philip, 69.
} 
scholars working on histories of recorded performance have continued to construct narratives through which to explain changing performance style.

Georgia Volioti asks whether a similarity in style between performers guarantees their historical connection, and whether the absence of a similar style means that there is no connection. Though the answer is clearly in the negative, that is, two musicians working within the same tradition do not necessarily play in a similar manner, her investigation reveals some important assumptions that lay latent within much work that deals with tradition in performance.

Volioti theorizes tradition as existing in two senses: as an historical force, which acts upon individuals and offers them a limited set of interpretative choices based on the past; and as an agentive force, in which individuals are free to make their decisions about performance in a given context. She references Bourdieu's idea of habitus, which theorizes the individual's ability to make decisions within the constraints of a given social context. However, Volioti also wants to step outside of a paradigm which sees performers in terms of their ability to conform to or deviate from tradition. Believing that this view places too much focus on the power of tradition at the expense of individual agency, she looks for an alternative in the social theory of HansGeorg Gadamer. Gadamer wants to put the individual at the center of tradition, which he does by pointing out that without the voluntary action of every individual to communicate with others in a particular way, there would be no tradition. ${ }^{155}$

\section{Ontological Premises of Analyzing Recordings}

The ontology of the musical work is a topic that nearly every writer on the history of recorded performance has discussed, and almost all agree that the idea of the work-concept

\footnotetext{
${ }^{155}$ Georgia Volioti, "Playing with Tradition: Weighing up Similarity and the Buoyancy of the Game. Musicae Scientiae: The Journal of the European Society for the Cognitive Sciences of Music XIV/2 (Fall 2010): 85-114.
} 
residing exclusively in the score is fallacious. Nicholas Cook's monograph Beyond the Score: Music as Performance has presented perhaps the most sustained argument against the residual ideology that regards the musical work as residing within the text. The tendency to see performance as subsidiary to composition and to analysis still runs strong, and is one of the major foils to Cook's way of thinking. As he points out, these ideologies are perhaps not held in the minds of musicologists, but traditions of discourse have made their removal difficult. Writing in 2013, Cook wants to establish a view of the musical work that understands performance as not only part of the work, but as its most important meaning-making aspect. As an ardent advocate for the importance of performance, Cook advocates an approach that sees performance, rather than the score, as the ultimate determinant of meaning in music. Eschewing what he terms the "page-to-stage" approach, in other words using the score as the basis on which to model performance and to interpret recordings, Cook wants to implement an epistemology of meaningmaking through the act of performance.

Cook critiques a history within musicological writing that sees performers as simply reproducing scores, showing that it is an historically-situated idea that exists as only one interpretive option. While this critique is nothing new in writing on the topic, Cook's contribution is to follow up the critique with an idea of music as performance that he hopes will open up new ways of thinking about, experiencing, and performing music. His central contention is that in accepting that music originates in the score, musicologists have ignored that much musical meaning comes out of performance. Instead, we can enrich our thinking about music by treating performances, mainly recordings, as equally valuable sites of meaning. Cook writes that "I want to address the issues of culture and meaning that concern most musicologists, but to build performance deeply into their formulation, and make it possible to bring the specifics of 
individual performances —often in the form of recordings— to bear upon them.. ${ }^{, 156}$ Additionally, Cook wants to help performers expand their range of available interpretive possibilities, which he believes have been constrained because of the assumption that music begins on the page. As he writes, "music affords an apparently unlimited variety of interpretive options, and we could be much more adventurous in our exploration of them if our thinking about performance was more flexible." ${ }^{157}$ As Cook notes, the long history of writing about music as a text that stands outside of history still holds sway, because methods of thinking about and analyzing music have developed out of this stream of thought. Because these ideas are so ingrained, they will be difficult to change, but Cook wants to integrate his approach with the older model, not overthrow it: "My aim is not to displace traditional musicology but rather to rethink it from the inside. ${ }^{.158}$

José Bowen, writing before Cook in 1993, also points out that "scores are not musical works." ${ }^{159}$ He uses M.M. Bakhtin's literary theory to support a new approach to thinking about musical works. Bakhtin theorized that language is performative, in the sense that when uttered, it acts in two ways: one which strives toward unity, in order to make itself understood by others, and a second which strives toward uniqueness, which tends toward a break in communication. Bowen maps these ideas onto music, seeing each musical performance as a unique utterance of a more broadly accepted idea of a musical work, which includes the score. Based on Bakhtin's ideas, Bowen concludes that we should consider performance to be an important—if not central—part of the musical work.

\footnotetext{
${ }^{156}$ Cook, Beyond the Score, 1.

${ }^{157}$ Ibid, 2.

158 Ibid, 1.

159 José Bowen, "The History of Remembered Innovation: Tradition and Its Role in the Relationship Between Musical Works and Their Performances," Journal of Musicology 11/2 (Spring 1993): 141-44.
} 
These arguments for music as performance are still necessary and relevant today, and build on similar arguments for broader ontological conceptions of music from past writings on the subject. Christopher Small's idea of musicking from 1998, for example, provides a comprehensive view of music and meaning that includes not just performance, but also any act of musical activity. Listening to music, thinking about music, even singing in the shower are all part of Small's idea of meaning-making musical activities. Cook acknowledges Small's contribution, as well as similar ideas from philosopher Stan Godlovitch and Robert Martin, and mentions that the new musicology helped to open up the possibility of thinking about music as performance. $^{160}$

The problem remains, however, that musical texts remain in many cases our only connection to the history of music. Cook makes his case for analyzing performance from the last hundred years as it exists in recordings, and about the creative possibilities opened up by thinking about music as performance. But thinking about music as performance and analyzing recordings of performances are two separate actions. We can just as easily read a score and think about performance, or play music and write about it as embodied practice and performance. Alternatively, we can analyze recordings as texts, something that it is all too easy to do when we use software to analyze them. Because music analysis software turns sound into a visual map, it becomes possible to "see" a recording as a single act, represented in simultaneity on a page. I use the software program Sonic Visualizer in this chapter as a visual aid to analyze recordings. I also take Cook's approach to understanding music as performance. ${ }^{161}$

\footnotetext{
${ }^{160}$ See Christopher Small, Musicking: The Meanings of Performing and Listening (University Press of New England, 1998).

${ }^{161}$ I take this idea from Nicholas Cook, Beyond the Score: Music as Performance (Oxford University Press, 2013): 34.
} 
Another unrecognized result of the many attempts to establish grand narratives of performance history, whether they attribute agency to technology, to historical forces, or to individuals, is their tendency to normalize and to marginalize certain kinds of behavior. If one accepts, for example, Philip's model of performance history, performance standardizes as the century moves on. A recording that does not fit the narrative can be dismissed as an outlier, thus establishing a hierarchy of taste, or grounds for judgment, about past culture. If one of the goals of establishing histories of performance is to understand how taste has changed and thus to reflect on our own senses of taste, then a close, perhaps unwelcome, outcome of this goal will be to continue to draw lines of distinction between good and bad taste, all of which must be vigilantly recognized as culturally contingent and arbitrary. The most we can hope for coming out of the analysis of recorded performance is a better understanding of relationships between cultural products of particular times and places, in order to better understand how these relationships continue to work on us today.

As Rink, et al wrote, “one-to-one mapping from musical scores to performances is far from adequate as a way of explaining expressivity in musical performances."162 Following this thread, I propose that in order to understand expressivity in performances, and more generally the choices that performers make, we must understand how the music was understood as the performers were developing their playing styles. To do this, I will explore Beethoven historiography during the twentieth century, in order to understand how performers of a given time period may have thought of the composer. As such, the methodology employed in this chapter does not use an "average" of performances for any given time period. Instead, I explore

\footnotetext{
162 John Rink, Neta Spiro, and Nicolas Gold, "The Form of Performance: Analyzing Pattern Distribution in Select Recordings of Chopin's Mazurka Op. 24 No. 2," Musicae Scientiae (2010): 49.
} 
the connection between the playing style of each performer and its associated view of the composer in order to understand the wider context in which the performance occurs.

This chapter does not attempt to construct a grand narrative about the way that performance style of Beethoven's sonatas has changed throughout the twentieth century. Its task, instead, is to understand the relationship between views of Beethoven and the analysis of his music on the one hand, and its performance as documented in recordings on the other. I compare recordings and writings from different times in order to understand how the relationship between writings about Beethoven and performances of his music have changed over time. The next section will outline the competing views of Beethoven in the beginning and middle of the twentieth century.

\section{Historiography of Beethoven and the Performance of His Music}

The understanding of Beethoven and his music has undergone significant changes in the twentieth century. Scott Burnham narrates the transition, around 1927, from what he calls Beethoven "as redeemer" to Beethoven "as lawgiver and bearer of Classical values." In the former view, exemplified in Wagner's monograph Beethoven from 1870, the composer is portrayed as the embodiment of the Germanic spirit. As Wagner paints it, Beethoven's Germanic spirit is contained within his music, which expresses an inward purity through its ever-present and unifying melody. Beethoven's outpouring of spirit throws off the changeable fashion of appearances, a Wagnerian interpretive move directed toward the French, whose culture, in Wagner's eyes, the Germans had relied upon for too long. Wagner and his followers, instead, understand Beethoven to be the savior of the German people, whose good works are his 
transcendent and eternal music. Beethoven's music thus contains within it the ability to reshape the world around it into an image of the true German spirit.

As Wagner developed his view of a transcendent, mythological Beethoven, Alexander Wheelock Thayer's biography, begun in 1866, constructed a more sober, empirical image of the composer. Influenced by literary realism, Thayer's work sought to paint an accurate portrait of Beethoven while eschewing the influence of Romantic philosophy. While Thayer's work was initially dwarfed by the towering figure of Wagner, his approach to Beethoven scholarship was taken up in the German academy following the decline of Expressionism and the horrors of the First World War. For scholars such as Arnold Schmitz and August Halm, Beethoven was the antithesis of Wagner's revolutionary redeemer; instead, the composer became a paragon of morality, whose music exhibits a model for the rule-following, respectable citizen.

Schmitz and Halm sought classical values of balance and proportion in his music, as part of a search for unity. Its unity was the ultimate indicator of its sobriety and upstanding morality. Such unity was to be found in Beethoven's musical motives; in 1925, Walter Engelsmann proposed that each of Beethoven's sonatas were developed from a single motive, formulating the idea as a natural law. Arnold Schoenberg took this approach to his compositions, using ideas of the motivic-based developing variation and the twelve-tone system, tools with that emphasized motivic unity. Heinrich Schenker proposed a different kind of unity with his analytical system, which interpreted surface-level incongruities as hiding a deeper unification of structure predicated on voice-leading.

By 1970, views of Beethoven had shifted again, in one significant way for our purposes here. Burnham identifies a new strain of Beethoven scholarship which sees the composer as a 
historical figure who can no longer be truly identified with and who is the product of social forces. Burnham posits that scholars felt an inescapable divide between the composer and the present time. No longer feeling a close connection to the past as there had been before, scholars began to piece together a distanced perspective on the composer. ${ }^{163}$

Alain Frogley traces a similar history within the performance tradition of Beethoven's music, showing how the dominant tradition transitioned from a Wagnerian approach in the decades surrounding the turn of the twentieth century to an objectivist approach in the years after World War I. Wagner's view of the composer, Frogley shows, had a profound influence on the performance of his music. Because Wagner emphasized the spiritual underpinnings of Beethoven's art and disdained approaches that focused on appearances, he felt free to change the music in order to express the underlying spirit. Therefore, Wagnerian performance practice included much tempo modification, which he used in order to emphasize that ever-present melody, which he called melos, that expressed the spirit of Beethoven's music. Wagner was also unafraid to change Beethoven's scores; for example, he rewrote the flute and first oboe parts in mm. 138-43 of the first movement of Beethoven's ninth symphony in order to bring out the structurally significant melos.

Frogley identifies a competing performance history from the nineteenth century whose most prominent members include Berlioz and Mendelssohn. While Wagner believed that the progress of music necessitated that performance and scores be reworked to fit a more advanced understanding of music, Berlioz and Mendelssohn both advocated a more literal interpretation of the original score. This approach was based on the belief that the unaltered score represented the

\footnotetext{
${ }^{163}$ See Scott Burnham, "The Four Ages of Beethoven: Critical Reception and the Canonic Composer," in The Cambridge Companion to Beethoven, (Cambridge University Press, 2000): 272-91.
} 
music accurately. In describing his opinion on this matter, Berlioz uses a metaphor in which he compares the composer and score to a painter and a painting, and the performer to the sun whose function it is to illuminate what is already there, without addition or subtraction. ${ }^{164}$

Despite the practices of Mendelssohn and Berlioz, Wagner's influence loomed larger toward the end of the nineteenth century. While there were dissenting voices during this time, they remained largely unnoticed until the years following the end of the First World War and the rise in popularity of the Italian conductor Arturo Toscanini. The motivations for and traditions behind Toscanini's approach to performance are in dispute; in any case, his style sharply diverged from the Wagnerian tradition, in a direction more in line with that of Mendelssohn and Berlioz. His insistence on rhythmic rigidity gave his performances a sense of precision and clarity which, combined with his willingness to eschew tradition, enticed followers of Modernist movements, such as the "new objectivity" and Stravinskian neo-Classicism, to support his new conducting style. ${ }^{165}$

The close alignment of the two traditions — one of writing about Beethoven and the other of performing Beethoven —is easiest to see in their fast-changing trajectories during these interwar years. The emergence of the Neue Sachlichkeit and neo-Classicism in composition, along with the appearance of strictly rhythmic, Toscanini-derived performance styles, formed the basis of a revolution in both traditions.

Performance issues after the interwar seismic shift are less well-defined in Frogley's account, and therefore do not correspond as neatly with the musicological shift around 1970 that

\footnotetext{
${ }^{164}$ Richard Taruskin offers a different view of the nineteenth-century performance tradition from which Toscanini emerged, drawing from Karol Berger. See "The New Antiquity" in Richard Taruskin, Text and Act: Essays on Music and Performance, (Oxford University Press, 1995): 223.

${ }^{165}$ Alain Frogley, "Beethoven's Music in Performance: Historical Perspectives," in The Cambridge Companion to Beethoven, (Cambridge University Press, 2000): 255-71.
} 
Burnham describes. Frogley does write about the historic performance movement as the most influential of recent developments in Beethoven performance. He does not, however, connect it to any related movement in writing on the composer. This indicates a gap between performance and scholarship that emerges around this time. Historical performance practice, which staked out its own claims to authenticity based on historical evidence, contradicted the claims to authenticity and authority offered by modernist performance practice as well as modernist writing. This resulted in an opposition of ideologies of performance. Modernist performance, such as that of Toscanini, was based on the authority of tradition and of formalism, while historical performance practice was based on historical reconstruction and antiquarianism. These seem to have remained at odds with each other until Richard Taruskin intellectually subordinated the historical performance movement with his attacks on its ideology, collected in the volume Text \& Act from 1995. ${ }^{166}$

\section{The Guides to Beethoven's Piano Sonatas: Ideological Affinities}

Guides to the piano sonatas from these interwar years help to understand the affinities in attitudes between historians and performers during this time, particularly with regard to the sonatas. Pianist, composer, and writer Donald Francis Tovey’s (1875-1940) A Companion to Beethoven's Pianoforte Sonatas from 1931 is a paradigmatic expression of the Classicist view of the composer. Leaving behind the vestiges of the nineteenth-century splenetic Beethoven, Tovey presents a calmly calculating composer whose ultimate aim is the perfection of form. The composer, according to Tovey, achieves this through the implementation of large-scale organic unity. Stressing that the compositional unity comes from within each work, "instead of being imposed from without", Tovey argues that the form and the content work together to create each

\footnotetext{
${ }^{166}$ Richard Taruskin, Text \& Act (New York: Oxford University Press, 1995).
} 
other. Using the example of a Bach chorale-prelude, he points out that in such a piece, the chorale melody serves as a melodic structure, while the harmony of the chorale underpins the more frequent worked-out harmonies. Using these ideas, he argues that we can think of works as organic wholes whose content is influenced by form and vice versa. Tovey believes this is an attainable goal; he wishes to discover organic unity in every sonata. Tovey is also concerned with the sense of proportion in Beethoven's works, comparing them to those of Haydn and Mozart. ${ }^{167}$

Tovey's analysis of Op. 10 bears out his focus on form and his avoidance of any discussion of the composer's biography or of expression. Noting the similarity between the tempo of the first movement and of Haydn's Op. 50, No. 5 quartet, as well as the difference in their designs, he then proceeds to give a bar-by-bar analysis of the themes and phrases. He labels figures using letters, parsing out phrase lengths and types, but restricting himself entirely to the language of harmony, melody, phrasing, and the relationship between these structures. ${ }^{168}$

Eric Blom, an Englishman born in 1888, worked as a music critic for the Manchester Guardian and the Birmingham Post through the 1920s and 30s and into the 1940s, and later became the editor of Music and Letters and the fifth edition of Grove's Dictionary. He also published extensively on a wide variety of musical topics, including a history of music in England, an "Everyman's" dictionary of music, many entries in the Grove's Dictionary, and a guide to the piano sonatas of Beethoven. ${ }^{169}$ Written starting in 1932 and published in 1938, Blom's Beethoven's Pianoforte Sonatas Discussed is a compilation of essays and annotations of

\footnotetext{
${ }^{167}$ Donald Francis Tovey, A Companion to Beethoven's Pianoforte Sonatas (Associated Board of the R.A.M. and the R.C.M., 1931): 7-8.

168 Ibid, 50-51.

169 "Blom, Eric," in The New Grove Online.
} 
the piano sonatas that first appeared alongside records published by the Beethoven Sonata Society. Blom's discussion represents both the post-Wagnerian, orderly Beethoven as embodied by Schmitz and Halm, and the older idea of the composer as a mysterious metaphysical force. As such, Blom's discussion reveals a mixture of old and new ideas about Beethoven.

Blom reveals his attitudes toward the composer in the prelude, "The Place in History." Here, Beethoven stands at the apex of a mystical History of Music; his power is so great, it flows both forwards and backwards in time. Blom writes how Beethoven's great achievements even manage to affect Haydn's earlier sonatas, "almost as though the influence had worked by some mysterious backward process that disregarded time." 170

In a typically Romantic gesture, Blom portrays Beethoven's music as embodying his personality. This is a personality with particular characteristics; Blom paints Beethoven as a revolutionary rule-breaker whose music cannot be constrained by inherited norms, paralleling his unbridled personality. Instead, even in the third movement of the early Sonata Op. 2 No. 2, “A movement that is meant to have a character of kittenish playfulness shows the lion's claw almost before Beethoven is aware of the self-betrayal.” For Blom, this urge to revolutionize, via wild outbursts and hidden rage, typifies Beethoven's earliest sonatas, “first movements full of impetuosity, splenetic scherzos, adagios and andantes whose calm beauty clearly covers up suppressed fires, and rondos that let us suspect the whims and sudden gusts of temper that we find in Beethoven's letters."171

At the same time, Blom provides an understanding of the rule-following, Classical Beethoven. Balancing out his whimsicalities and impetuosity is his powerful discipline, which

\footnotetext{
${ }^{170}$ Eric Blom, Beethoven's Pianoforte Sonatas Discussed, unabridged republication of the first edition published in 1938 (New York: Da Capo Press, 1968): 2.

${ }^{171}$ Ibid, 3.
} 
expresses itself in "his self-controlled independence in the matter of form" and his "mastery over [form's] adjustment to invention.” Here, Blom defends Beethoven's eighteenth-century musical inheritance against Wagner, in particular the transitions between first and second themes, for which "of course there is more to be said...from the point of view of eighteenth-century aesthetics, than Wagner could fit in with his own theories." For Blom, Beethoven represents both the revolutionary figure of mature Romanticism and the ordered one of the newly emerging neoClassicism.

Blom's analysis of Op. 10, No. 2 follows his twin emphasis on form and expression, while also maintaining the presence of Beethoven's authorial voice in the sonata. He writes that this sonata is full of "the typically Beethovenian humour which shows itself in abrupt statement of short sentences and in a habit of twisting and turning them, very much as he twisted words into puns and nonsense rhymes in his letters." He traces the themes and key areas while also elaborating on the expressive import of the aspects of form. For example, he suggests that in the transition from the first to the second theme, "Beethoven, with comic abruptness, goes to C major, the proper key for the second-subject group in a movement in F major...He has thus reached this feature quite unexpectedly." 172

These two writers show the shift in perspective on the composer. The older perspective understood Beethoven's music to be an extension of the composer himself; the new one dropped the composer from consideration of the music. From the point of view of performance and analysis, the move eradicated the composer, and by extension, the culture in which he lived, from his music. Nowhere in Tovey's writing is anything resembling Blom's focus on the unpredictable personality of the composer. Instead, he discusses the music in terms of principles

\footnotetext{
${ }^{172}$ Ibid, 39.
} 
of key-relations, harmonic analysis, and organic unity, all of which are far removed from the importance that Blom places on the spirit of the composer.

Guides to the piano sonatas from after the Second World War retain this theme. Rudolph Réti's Thematic Patterns in Sonatas of Beethoven builds on the ideas of formal and structural coherence to which Tovey gives priority. Written in the 1940s and 50s and published posthumously in 1967, the book attempts to account for all aspects of compositions by means of small motivic cells. Réti formulates his theory of composition at the outset, stating that "[e]very musical composition on a high structural level contains several motivic cells from which its structure is formed." 173 This statement is reminiscent of Schenker in its "structural levels" and of Schoenberg with its "motivic cells," the latter whose Op. 11 piano pieces Réti premiered in $1911 .^{174}$

The book is less a performance guide than an abstract analysis, an indication of the kinds of concerns in regard to Beethoven sonatas that occupied musicological discourse in the 1940s and 50s. Encapsulating the tendency of the age to isolate music from society, there are no references to the figure of Beethoven or his social world, but Réti instead assumes the existence of the work's own life; we read about the "structural life" of Beethoven's Pathétique. ${ }^{175}$ Réti's strong desire to find structural unity is also reminiscent of Tovey's writing, and it shows itself through a similarly pan-historical idea of a rule of form; just as Tovey writes of how the underlying melodic structure of Bach's chorale-prelude accounts for nearly all of its notes, Réti writes that "[f]or this small list of four motifs covers every note in every voice of this opening

\footnotetext{
${ }^{173}$ Rudolph Réti, Thematic Patterns in Sonatas of Beethoven, (New York: Macmillan Co., 1967): 17.

174 "Réti, Rudolph," Grove Music Online.

${ }^{175}$ Thematic Patterns, 17.
} 
period. Just as in a fugue of Bach, though there effected through a different technique, nothing remains outside the structural unity."176

Charles Rosen's Beethoven's Piano Sonatas: A Short Companion from 2002 continues the overriding concern with structure. In his book, formal coherence underlies the interpretation of the sonatas; its centrality goes unquestioned, to the extent that there needs to be no argument in its favor. Instead, the first chapter explains how Beethoven probably thought of form in his works, foreclosing the possibility of any other compositional concerns. This chapter, the only one that explicitly discusses "principles" of composition, concerns itself with tonal relations within movements, according to schemes drawn from the works of Mozart and Haydn. Rosen identifies two different schemes each for the exposition, the development, and the recapitulation, formulating them in terms of tonal relations and indicating Beethoven's, Mozart's, and Haydn's preferences with regard to each.

Rosen hints at interpretive criteria beyond form at the end of the chapter, when he states that " $[\mathrm{n}] \mathrm{o}$ other composer of sonatas has come near to such a wide range of character, style and form. ${ }^{\prime 177}$ Despite this, he does not extrapolate any principles of character, or give any historical basis for an understanding of this idea in the way that he does form. Instead, it seems to be an attribute that either derives from form and style, or one that matters but little in the sonatas.

Like his introduction to the sonatas, Rosen's analysis of Op. 10, No. 2 focuses on the key relations within the larger sonata form. He does mention the character of the sonata, writing that it "is in the comic mode, and it proclaims its witty eccentricity at once," and calls Beethoven's method for the quick modulation to the dominant, a leap from the dominant of a minor to C

\footnotetext{
176 Ibid, 23.

${ }^{177}$ Charles Rosen, Beethoven's Piano Sonatas: A Short Companion, (New Haven: Yale University Press, 2002$): 12$.
} 
major, "already banal," although he concedes that it had only been done in the transition from development to recapitulation. ${ }^{178}$

Robert Taub's book Playing the Beethoven Piano Sonatas, also from 2002, follows Réti in its view that the sonatas should be considered as self-enclosed entities. He writes of the "essence" and the "very being" of the sonatas, considering that each one "becomes its own world." While he does allow that each sonata has "ties nonetheless to the musical universe of which it is part," these connections are limited to Beethoven's sketches and letters. Taub follows Rosen in his strong focus on form and the genre of the sonata. ${ }^{179}$

Taub's depiction of Op. 10, No. 2 strays from this formula, and is instead filled with descriptions of the character of the piece. He tells us of his feelings in playing this piece, which include "questioning," "gentle playfulness," and "frolicsome." Taub follows this with advice on how best to achieve the proper effect in each section, commenting on the nature of the textures, melodies, and dynamic and articulation markings and giving the impression that these features are more important than the key areas and relationships. Taub's book is more of a playing manual, which follows from his vocation as primarily a performer.

Taub's testimony, in particular, attests to the pervasive idea that performers identify with their composers and works, and therefore understand the true "spirit" of the works. Such an idea, which is inherently ahistorical, runs counter to Burnham's claim that, since 1970, there has been a fracturing of the Romantic ideal of an identification with composers and works. While Burnham convinces us of the inescapable distancing of past musics from today's musicians, Taub's book provides solid evidence to the contrary. His strength of conviction in the possibility

\footnotetext{
${ }^{178}$ Ibid, 137.

${ }^{179}$ Robert Taub, Playing the Beethoven Piano Sonatas, (Portland, OR: Amadeus Press, 2002).
} 
of understanding the music as primarily a world unto itself, bolstered by knowledge of the sketches and the letters of its composer, clearly comes out of the ideology, also present in Réti, Tovey, and Rosen, that isolates the music from its time.

These guides to the piano sonatas show the shift from a passion-filled Wagnerian image of Beethoven to one that understands Beethoven's works as existing apart from his person, in an attempt at objectivity. And yet they still assume the metaphysical presence of a "spirit of form" within his works. In other words, the unity of his piano sonatas rests on a belief in an underlying formal coherence. While the authors of these works clearly rejected the notion that Beethoven's own spirit underlays these works, they simply replaced that metaphysics with a new one, which professed a belief in the unity of form. For the most part, my analysis of these guides falls in line with the histories written by Burnham and Frogley. Blom, the exception, expresses a combination of the Classical and the Romantic Beethoven, one that we will see in the recordings of his sonatas.

\section{Methodological Issues and Analysis of the Recordings}

For my analysis, I used the computer program Sonic Visualizer, developed by the AHRC Centre for the History and Analysis of Recorded Music. ${ }^{180}$ The program is particularly helpful in understanding tempo variations as they relate to dynamics. The practice of inserting beat counters into Sonic Visualizer, however, has also raised some issues about where to place beats. In most instances, placement is clear and easy. In some cases, however, performers give an impression of "coming in early," meaning that it sounds as if the beat actually comes after they play. In these cases, should one place the beat at the entrance of the piano tones, or slightly later

\footnotetext{
${ }^{180}$ See http://www.charm.rhul.ac.uk/index.html.
} 
based on how it "feels"? In all cases, I chose the former solution, because it is easier to find the sonic entrance than it is to establish a consistent "feel."

There are several critiques of performance analysis that need to be acknowledged. The most important one for my purposes is the assumption that there are discrete historical "styles", something that Cook seems to acknowledge but doesn't really address. My objection is the desirability of attempting to unite performers into an "average" of performance for a given time and place. This objection takes shape on the basis of what it will leave out; if we base a newly emerging history of performance on statistical analyses of hundreds of performances to establish a baseline of the average performance, then we have given in to the "big data" mentality and applied it to music analysis. For what do we establish averages and discover variations? Instead, I wish to compare historiography to recordings and thus better understand the relationship therein.

I adopt Daniel Leech-Wilkinson's idea that the birth date of a performer is more important than the date of the performance itself. ${ }^{181}$ Leech-Wilkinson argues that young, successful performers, shaped by their teachers and peers, develop a performance style that largely coheres to performance standards of their time, while also innovating to some degree. After they achieve success, Leech-Wilkinson says, there is little incentive to continue changing style. While there are exceptions to this rule (Rubinstein is one example), here I take it as given that the performers under consideration are all acting, more or less, according to this idea.

I have mapped and compared fourteen different recordings of the exposition of the first movement of Beethoven's piano sonata, Op. 10 No. 2. Despite arguments that there has been a

\footnotetext{
${ }^{181}$ Daniel Leech-Wilkinson, "Recordings and Histories of Performance Style." in The Cambridge Companion to Recorded Music, (Cambridge: Cambridge University Press, 2009): 256.
} 
trend toward standardization in recorded performance, ${ }^{182}$ there is quite a bit of individuality that yet remains, and all of the performers play the piece quite differently. Once we take Cook's insistence on the importance of performance as a basis for analysis, we can being to think of rhythm differently. The ability to analyze the small-scale tempo and rhythmic changes on recordings has opened up new possibilities of how to talk about time in music. Confined to the score, time looks as standardized as the industrial age, square and unyielding. Released to recordings, it becomes as nuanced as the individualized data that comes from clicks on the internet. As musicologists who are used to a beat representing a certain, definite unit of time on a page, it is slightly bewildering to attempt to reconcile that idea with what we hear on recordings. That beat becomes highly variable, with as many possible variations in itself as it has relationships to those around it.

Comparing the relative tempos and idiosyncrasies of rhythmic variation, it is possible to identify two trends that separate out different performers. One style emphasizes relatively extreme, frequent tempo variations and unpredictable beginnings and endings of phrases, a style represented by Schnabel and Sherman. The second playing style, in contrast, emphasizes continuity and smoothness, both in tempo and dynamics. This playing style is represented best by Kempff, as well as many of the younger performers. Nicholas Cook's ideas of structuralist and rhetorical playing help to partially explain this difference, but I argue below that there is also a strong connection to be made between these performances and Beethoven's twentieth-century historiography, particularly in the shift from Beethoven's image as a Romantic to a Classicist.

Artur Schnabel (1882-1951) is the oldest performer in the group, and his playing sounds the most foreign. He plays quickly and with a high degree of variability in the length of his beats.

\footnotetext{
182 Nicholas Cook, “The Ghost in the Machine," Musicae Scientiae (2010), 8, 13.
} 
To contemporary ears such as mine, it is unclear what the differently-sized beats are supposed to accomplish, for expression doesn't seem to be their goal. Instead, one gets the sense of an impatient performance, often focused on virtuosity and sometimes skipping past details of expression. This mostly takes shape at beginnings and ends of phrases, which can sound rushed. For example, at measure 9, the continuation of the phrase comes nearly a half beat early, which can be seen as a downward spike in the chart. ${ }^{183}$ Less extreme examples abound, such as measure 55 , proceeding into the closing theme, or measures 57-59, which repeat at 61-63, at which point the theme cadences on the dominant. These instances sound like mistimed rushing, less because of the increased tempo than because of their placement ahead of the beat.

Wilhelm Kempff's (1895-1991) recording, in contrast, sounds very rhythmically consistent, almost predictable, more in line with today's performance sensibilities. A comparison of his chart (chart 2) with that of Schnabel shows this to be the case. ${ }^{184}$ His beat lengths are much more closely bunched together than Schnabel's, and there are fewer spikes. The placement of those spikes is also revealing. While I noted Schnabel's tendency to rush through ends of phrases, Kempff generally slows down at ends of phrases. In fact, this happens so consistently that it perfectly encapsulates Nicholas Cook's idea, first enunciated by psychologist Neil Todd, of phrase arching, in which performers tend to begin a phrase quietly and slowly, speed up and get louder in the middle, and slow down and get softer at the end, thus creating an arc-like visual representation in both tempo and dynamics graphs. ${ }^{185}$ Kempff tends toward these three criteria, for the beginning, middle and ends of phrases.

\footnotetext{
183 See Table 1.

${ }^{184}$ See Table 2.

${ }^{185}$ Cook takes this idea from psychologist Neil Todd, who wrote about the idea in 1992. See Neil Todd, "The Dynamics of Dynamics: A Model of Musical Expression," Journal of the Acoustical Society of America 91 (1992):
} 
But while the idea of phrase arching is helpful to speak in general about how some performers play typical phrases, there is a great deal of variety in phrases themselves, which changes the general shape of an "arched" phrase. For example, measures 42-45 constitute an unusually shaped phrase. Here, the phrase begins $f f$ and remains that way, repeating its two-beat figure in the second measure before slowing its rhythms and yielding up a deceptive cadence. As might be expected of this shape, Kempff begins aggressively, then slows down and gets quieter at the cadence. In contrast, Schnabel drives toward the cadence by getting louder, but like Kempff, he also slows down at the end.

Phrase arching is a good indicator of what Cook calls structural playing, a playing style which attempts to bring the form of the piece to the fore by emphasizing those features of the music that articulate its structure. ${ }^{186}$ Cook argues that because of the dominance of structuralist discourse in musicology throughout much of the twentieth century, structuralist playing has come to be understood as the default, 'correct' way of playing. Indeed, structuralist performance has been so dominant, says Cook, that it has convinced many of "the assumption that it embodies a universal principle about how music should go in performance."187

In response, Cook points out that this way of thinking about music is in fact a product of modernist sensibilities, and he instead argues that it has everything to do with a twentiethcentury sense of time. According to Cook, this sense of time imposes an outside clock onto music performance, thereby insisting that performance fit into an objective sense of clock time. By historicizing structuralist playing, Cook thus reveals that it is not based on a "universal

3540-50. See also Cook's article "Squaring the Circle: Phrase Archings in Recordings of Chopin's Mazurkas." Musica Humana I/1 (Spring 2009): 5-28; and Cook, Beyond the Score, 276-79.

${ }^{186}$ See Cook, Beyond the Score, Chapter 2, "Page and Stage," 33-55; Chapter 4, "Beyond Structure," 91-134.

187 Ibid, 91. 
principle" that must be followed, but is instead only one performance option among other style choices. It is this sense of time that influences our hearing of Schnabel, who sounds like he is rushing and mistiming beats.

Cook proposes an alternative, rhetorical playing, which makes use of a conception of time that is ontologically different from that of structuralist playing. While the modernist playing assumes that music moves within time, rhetorical playing assumes music makes time, or as Cook says, is of time. Such a difference in understanding time can help to explain Schnabel's seeming temporal aberrations. This means that drastically shortened beats, like the one we find at measure 9 of Schnabel's recording, can be heard not as a jarring entrance; instead, the music could have power over time sufficient to enable such a drastic time shift.

While Cook's two conceptions of time help to clarify some of the differences in Schnabel's playing style, they do not explain the visceral feeling that Schnabel's playing remains just on the edge of control. He seems to be playing his fastest at times, even hitting wrong notes several times, which makes for a very exciting performance. Kempff, on the other hand, manages to remain in complete control of his performance, hitting no wrong notes and coolly playing phrases with perfectly planned-out crescendos and diminuendos, the consummate phrase-archer.

Such a stark contrast is consistent with the dividing line that Burnham draws between Wagner's Romantic Beethoven and Schmitz's Classical Beethoven. Schnabel, born thirteen years before Kempff, exhibits the Romantic style that searches for the infinite by balancing order with chaos. Kempff's playing is entirely ordered, the epitome of control. Just as the sublime, spiritual Beethoven of Wagner's creation gave way to the reasonable natural lawgiver of Arnold Schmitz, Schnabel's unpredictability evolved into Kempff's caution. And just like Blom's 
revolutionary and wild Beethoven and Tovey's coolly managed figure, Schnabel and Kempff show two sides of the binary for understanding his music.

Russell Sherman's (1930-) performance style largely follows that of Schnabel: the relatively quick tempo, the sudden dynamic changes, and the unexpected beat lengths all hearken back to the older pianist. Still, Sherman's performance is slightly more refined, aligning to tempo modulations that are more easily understood today. But Sherman's liner notes show that he is ideologically aligned to Schnabel, and to a Romanticized Beethoven. Beyond referencing Schnabel's writings, Sherman asserts that Beethoven's “music cannot be mastered, only addressed," thus inserting himself into the Romantic legacy and justifying the slightly chaotic manner of his playing. Alfred Brendel (1931-) hews closer to Kempff, remaining poised and predictable yet still fiery, allowing ample time for ends of phrases but pushing through more energetic sections.

Performers born later largely follow Kempff's model, a statement that is borne out by a comparison of the tempo charts. Two of our three pianists born in the 1940s, Richard Goode, Maurizio Pollini, and John O'Conor, are similar in temperament to Kempff. Goode and O'Conor align rather closely: both play in slower tempos, exhibit little rhythmic variation, and generally maintain strict control over the direction of the music. These two performances, like Kempff's, sound more planned out and less improvisational, while Pollini follows Schnabel in his unpredictability. He takes liberties in beat lengths, most immediately and drastically at measures 9 and 10, where he comes in surprisingly early at the beginning of the phrase, and then takes a very long beat on the turn figure. ${ }^{188}$

\footnotetext{
${ }^{188}$ See Table 4.
} 
The next generation consists of six performers, all born between the years 1954 and 1962: Ronald Brautigam (1954-), Melvyn Tan (1956-), Angela Hewitt (1958-), Louis Lortie (1959-), Mikulas Skuta (1960-), and Jean-Efflam Bavouzet (1962-). Among these are the two representatives of historically-informed performance, Melvyn Tan and Ronald Brautigam, who use fortepianos. That instrument's fast attack and decay and different timbre means that the timings in their charts can be misleading. Because the decay occurs so much faster, small variations in beat timings translate to a larger perceived change. In Tan's performance, for example, the short, quiet chord at measure 46 is isolated on both sides by rests that many performers accentuate with longer beat durations, resulting in elongated silences. What is different with Tan's performance is that his relatively short beat extensions here are amplified by the very fast decay. This means that the effect is very much the same as Louis Lortie, who inserts much longer beat extensions at this spot but whose silences come much slower as a result of the slower decay of the modern piano. Brautigam's performance, which is very slow, contains many silences, but it also has a great deal of reverberation which mitigates the effect somewhat.

The other major difference with Tan and with Brautigam is the lower dynamic ceiling on their instruments, which simply makes the loudest dynamics sound relatively tame in comparison to those of the modern instruments. Brautigam plays at one of the slowest tempos of the group, and he uses the extra time to exaggerate his expression. He seems to do this as a way to compensate for the smaller dynamic range. Despite his similarity to Lortie in certain ways, Tan's use of tempo cleaves closely to Kempff, while Lortie's performance uses time in more unpredictable ways. Out of this group, Skuta's and Bavouzet's performances are under scrupulous control, while Hewitt's playing is somewhere in the middle between Schnabel and Kempff's; her beats are occasionally surprisingly shortened or extended, like at measure 5 and 
toward the end at measure 59, but at other times she plays in accordance with predictable expectations. ${ }^{189}$

Finally, Paul Lewis (1972-) is the youngest of the group. He plays almost entirely in the Classicist vein, setting consistent tempos and playing perfectly arched phrases. It is possible to discern a combination of Romantic and Classical in the post-Kempff recordings of this collection. Richard Goode's playing toes the line, sounding slightly out of control at times, and manicured and smooth at others. For example, he plays the three repetitions of the augmented sixth chord at measures 16-18 at a surprisingly fast tempo, but then follows this with perfectly rounded, arched phrases in a section that can also sound wild.

\section{Conclusion}

While the ideas of structural and rhetorical playing help us to understand why Schnabel's use of time seems so foreign today, the competing views of Beethoven from this time-as Romantic and as Classicist—show their influence, aiding in explaining the difference between performances that flirt with disaster and those that sound eminently composed and controlled. On one extreme is Schnabel's playing, which feels just barely on the edge, a feeling that is visually represented in the tempo graph with its highly variable and unpredictable beat lengths. Russell Sherman, Maurizio Pollini, and Angela Hewitt largely follow this model, which to an extent builds on the Frühromantiker ideal of the infinite.

Kempff, by contrast, exhibits consummate mastery over the musical material. He tames its wildness, a manner of playing that is very much in line with the Classicism of writings and new ideas about the composer that were coming to the fore around the centenary of his death,

\footnotetext{
${ }^{189}$ See Table 8.
} 
just as Kempff was refining and perfecting his playing style. Most of the pianists in this survey follow Kempff's model, but many also show flashes of unpredictability.

But while these performances can be divided into the traditional Classicism-Romanticism binary, they do not necessarily succumb to its divisive politics. Perhaps because his music manages to successfully cross the divide, performances on both sides are possible, as are more subtly expressed ideological stances. Thus Russell Sherman, who insists that "the inherent tension between order and disorder, anomaly and stasis, event and field, is at its most refined and researched in Beethoven," is able to express a Romanticized Beethoven without identifying with the irrational or the regressive, while Kempff and others can convey a Classical, controlled Beethoven who still has moments of the infinite sublime. 
Table 1: Beat Duration Chart, Artur Schnabel (1882-1951), first movement of Op. 10 No. 2, Exposition

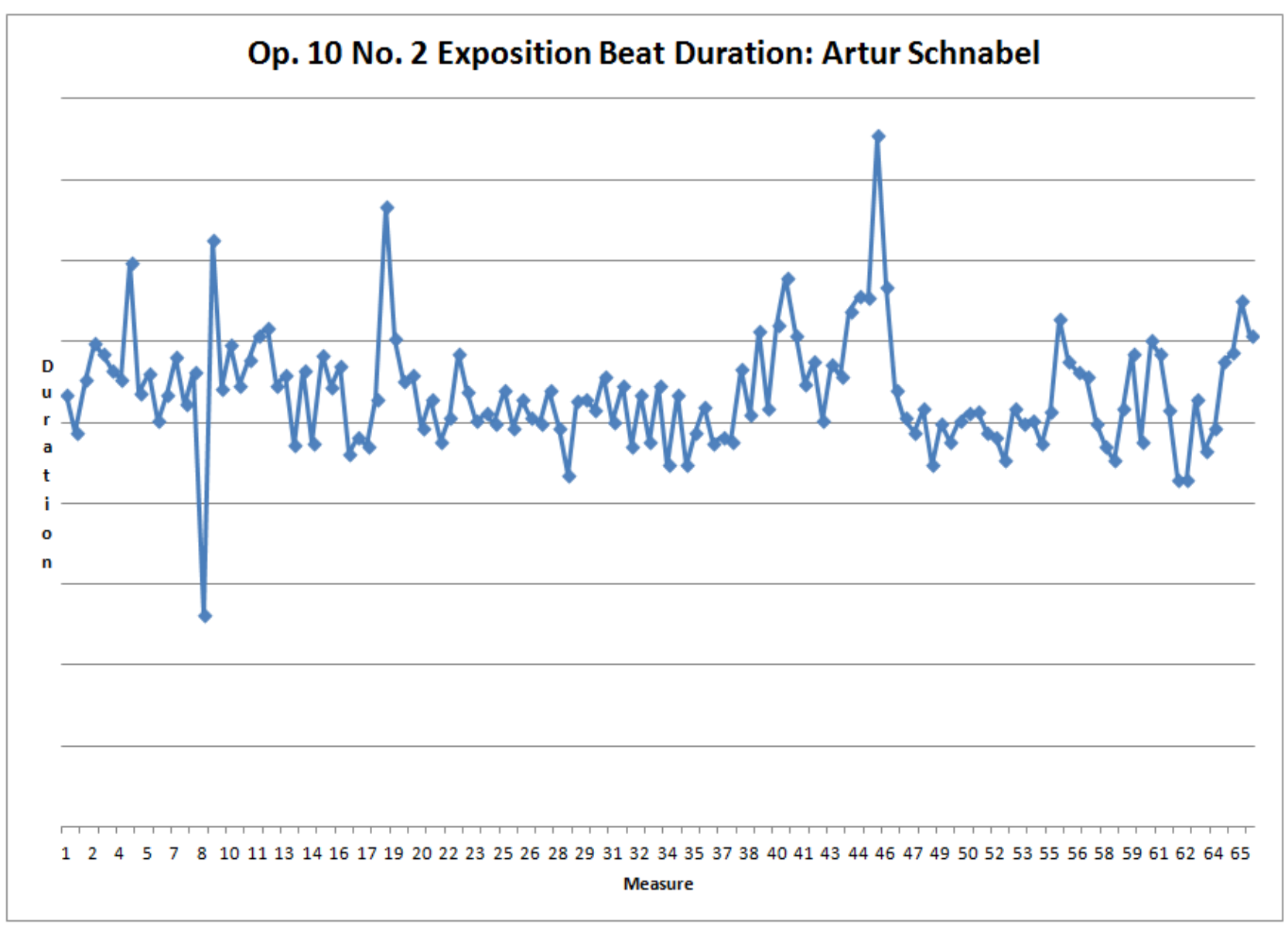


Table 2: Beat Duration Chart, Wilhelm Kempff (1895-1991), first movement of Op. 10 No. 2 , Exposition

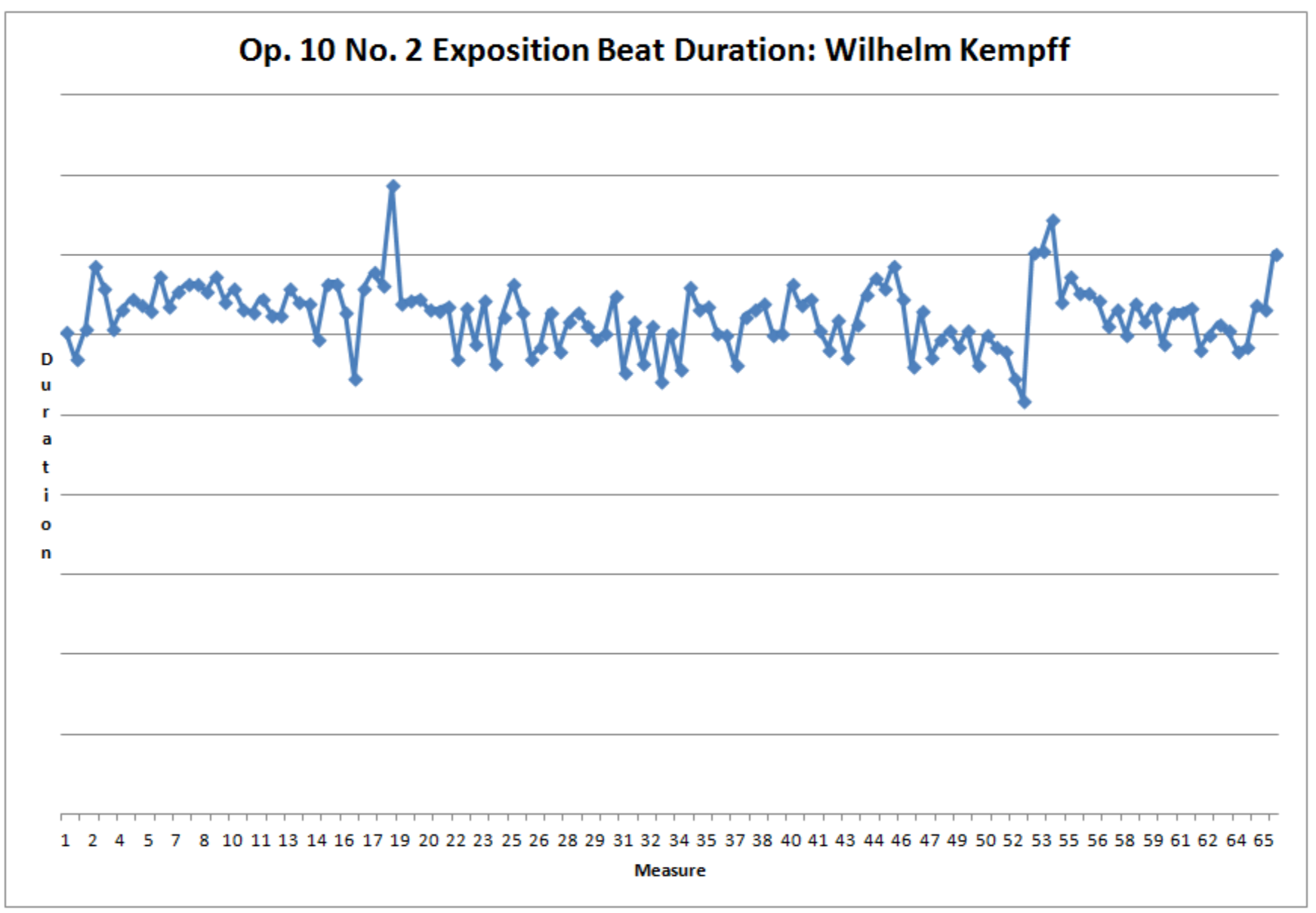


Table 3: Beat Duration Chart, Russell Sherman (1930-), first movement of Op. 10 No. 2, Exposition

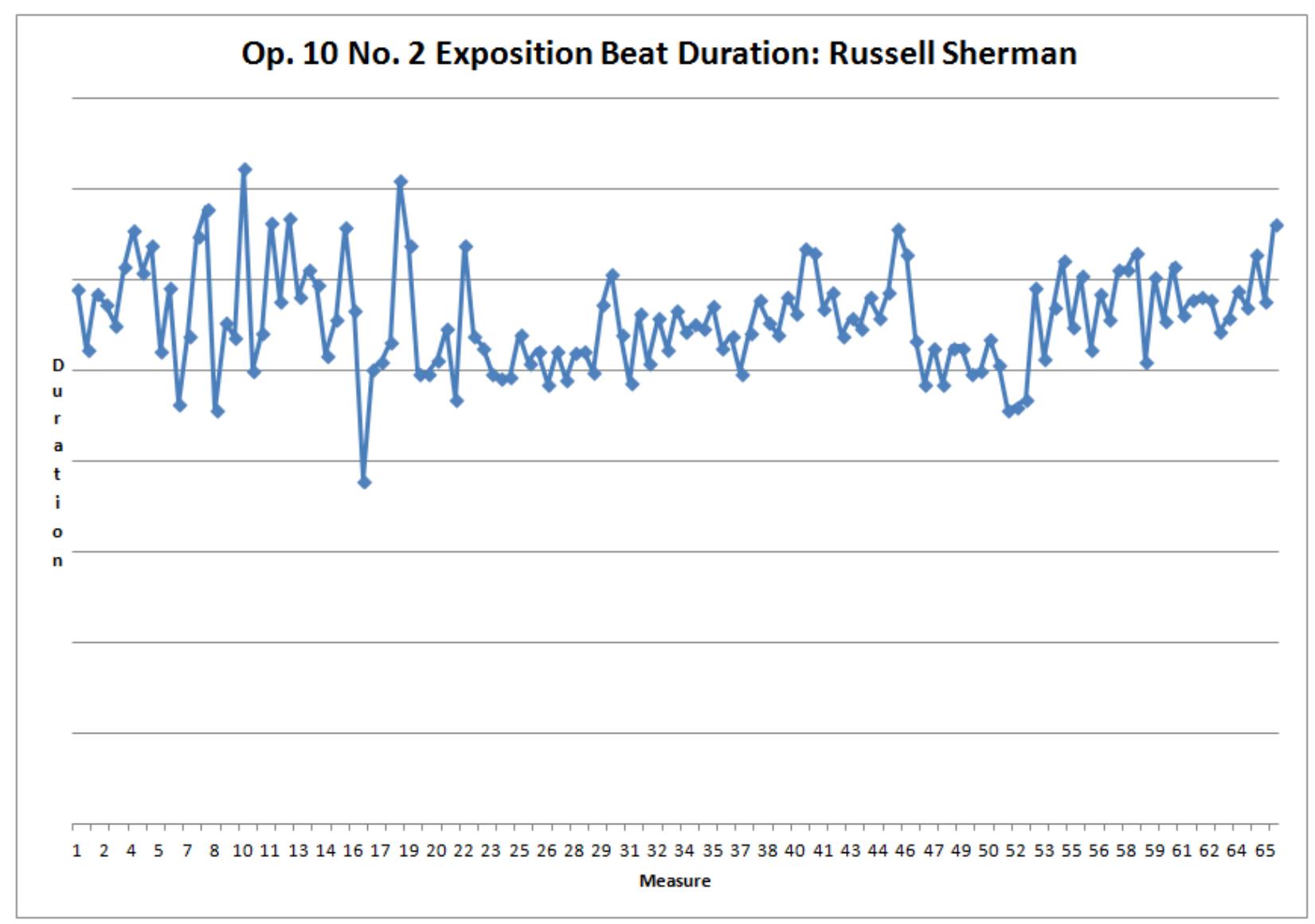


Table 4: Beat Duration Chart, Alfred Brendel (1931-), first movement of Op. 10 No. 2, Exposition

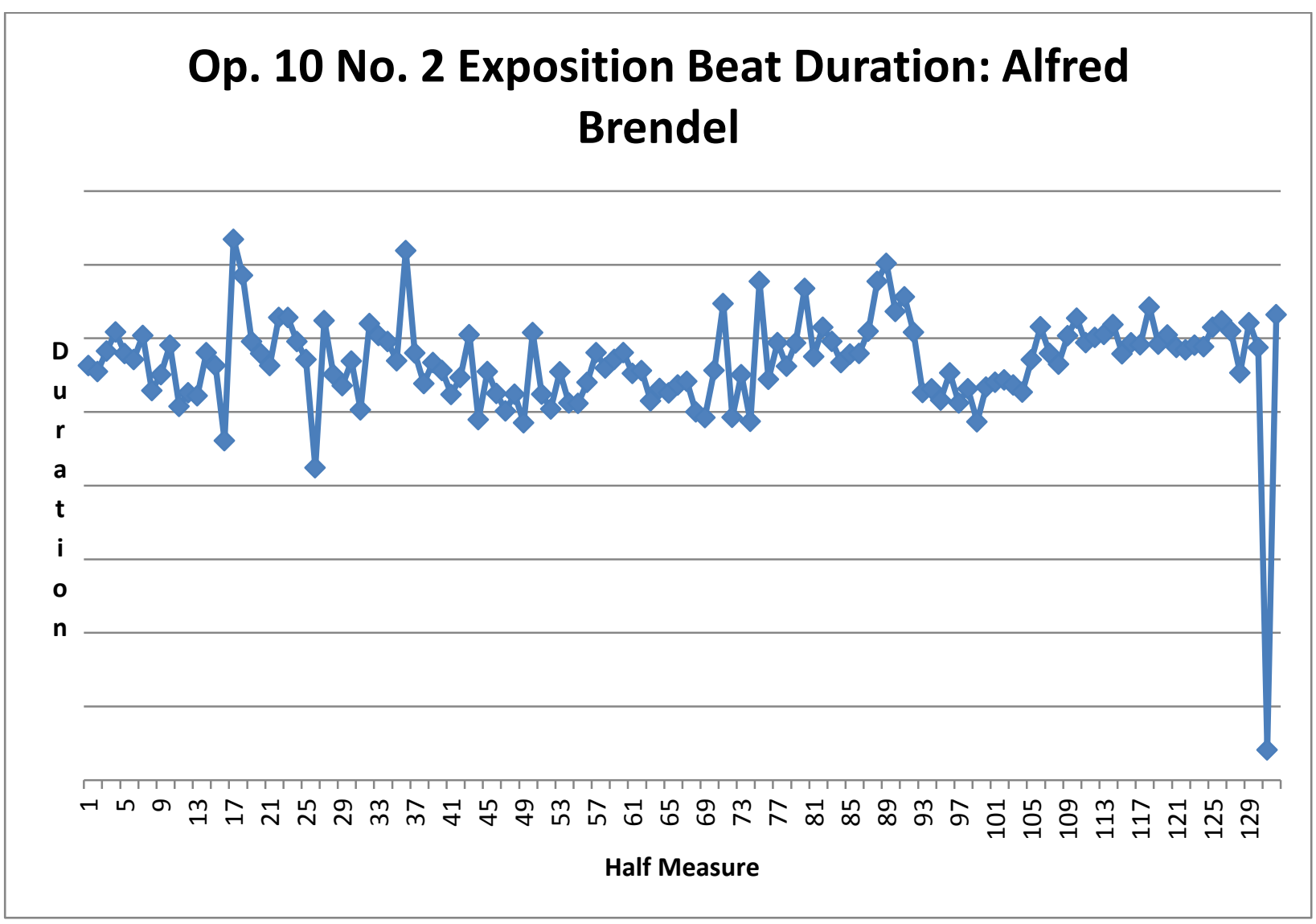


D’Elia 216

Table 5: Beat Duration Chart, Maurizio Pollini (1942-), first movement of Op. 10 No. 2, Exposition

Op. 10 No. 2 Exposition Beat Duration: Maurizio Pollini

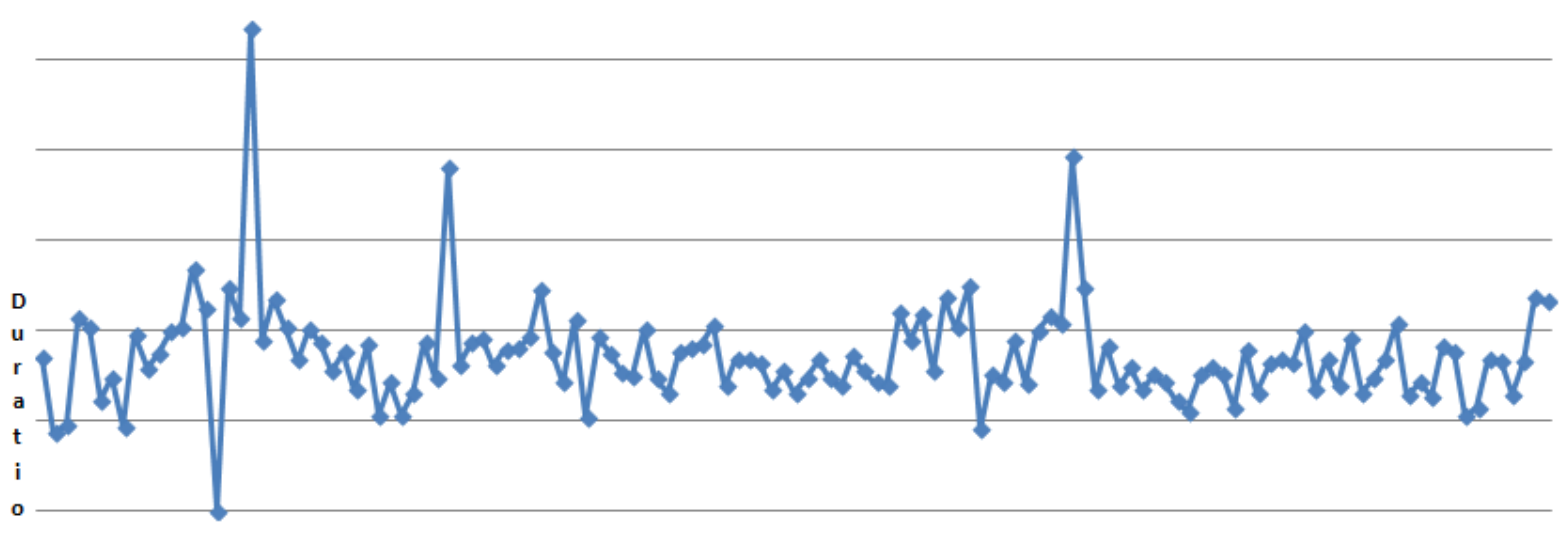

n

$124 \quad 5 \quad 7 \quad 81011131416171920222325262829313234353738404143444647495052535556585961626465$

Measure 
Table 6: Beat Duration Chart, Richard Goode (1943-), first movement of Op. 10 No. 2, Exposition

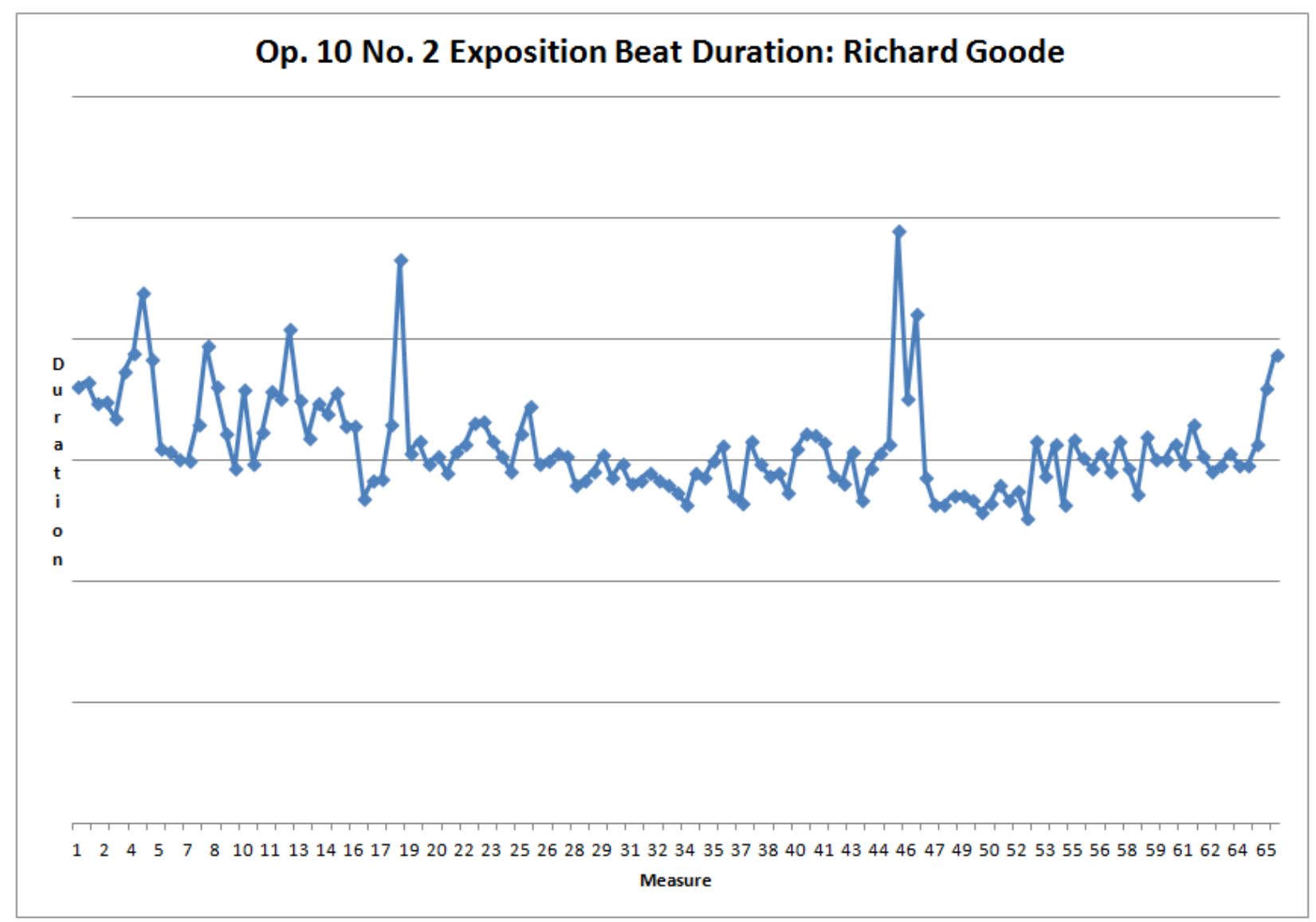


DElia 218

Table 7: Beat Duration Chart, John O'Conor (1947-), first movement of Op. 10 No. 2, Exposition

Op. 10 No. 2 Exposition Beat Duration: John O'Conor

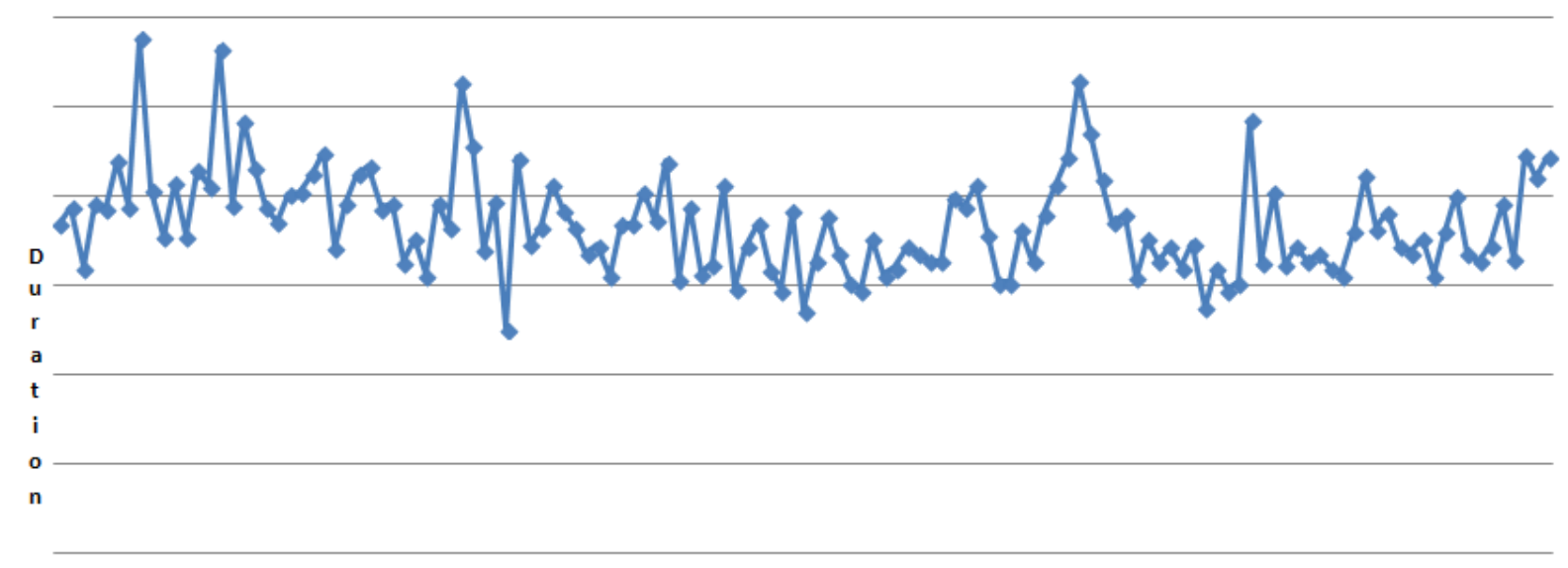

$124 \quad 5 \quad 7 \quad 81011131416171920222325262829313234353738404143444647495052535556585961626465$ 
Table 8: Beat Duration Chart, Ronald Brautigam (1954-), first movement of Op. 10 No. 2, Exposition

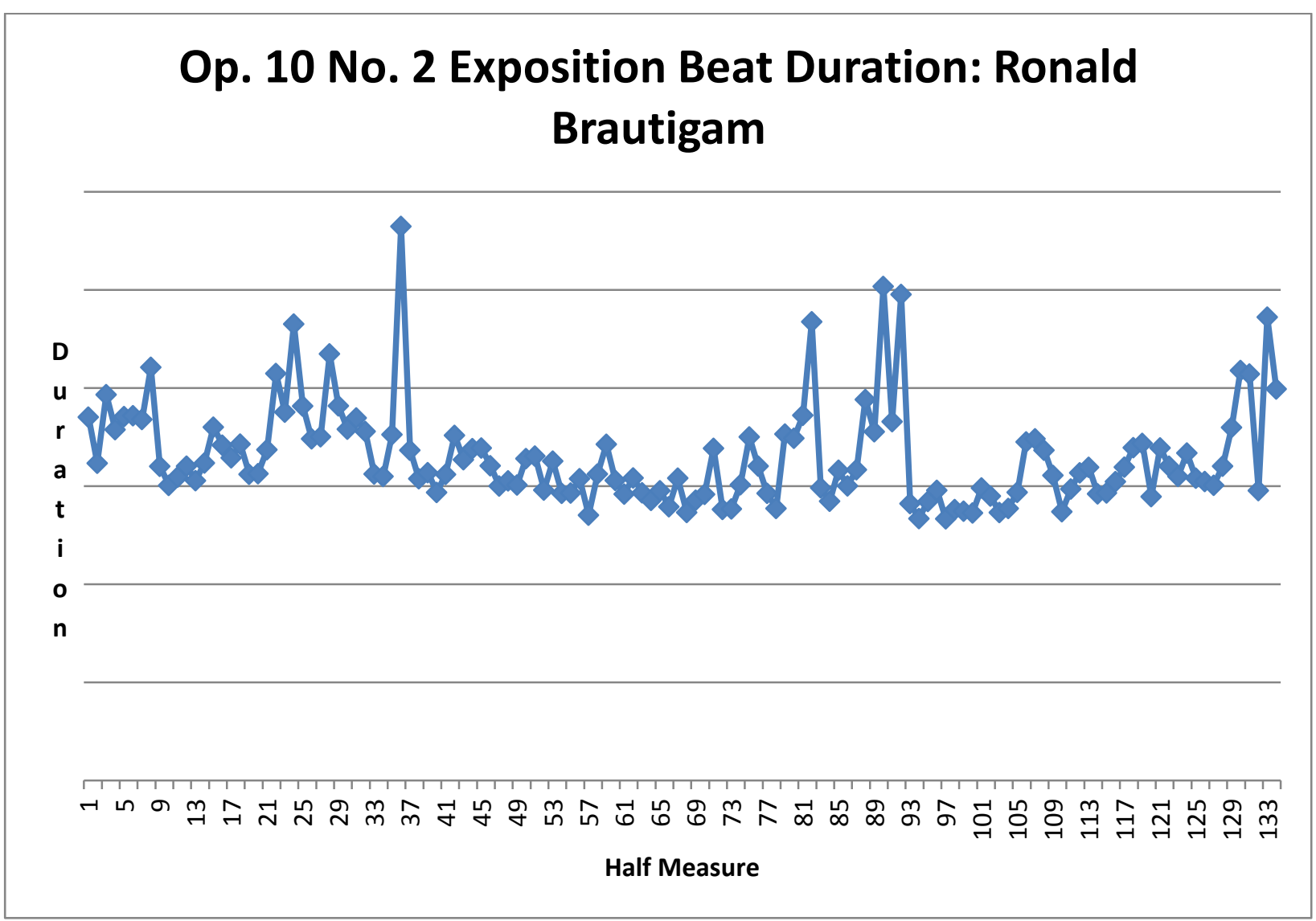


Table 9: Beat Duration Chart, Melvyn Tan (1956-), first movement of Op. 10 No. 2, Exposition

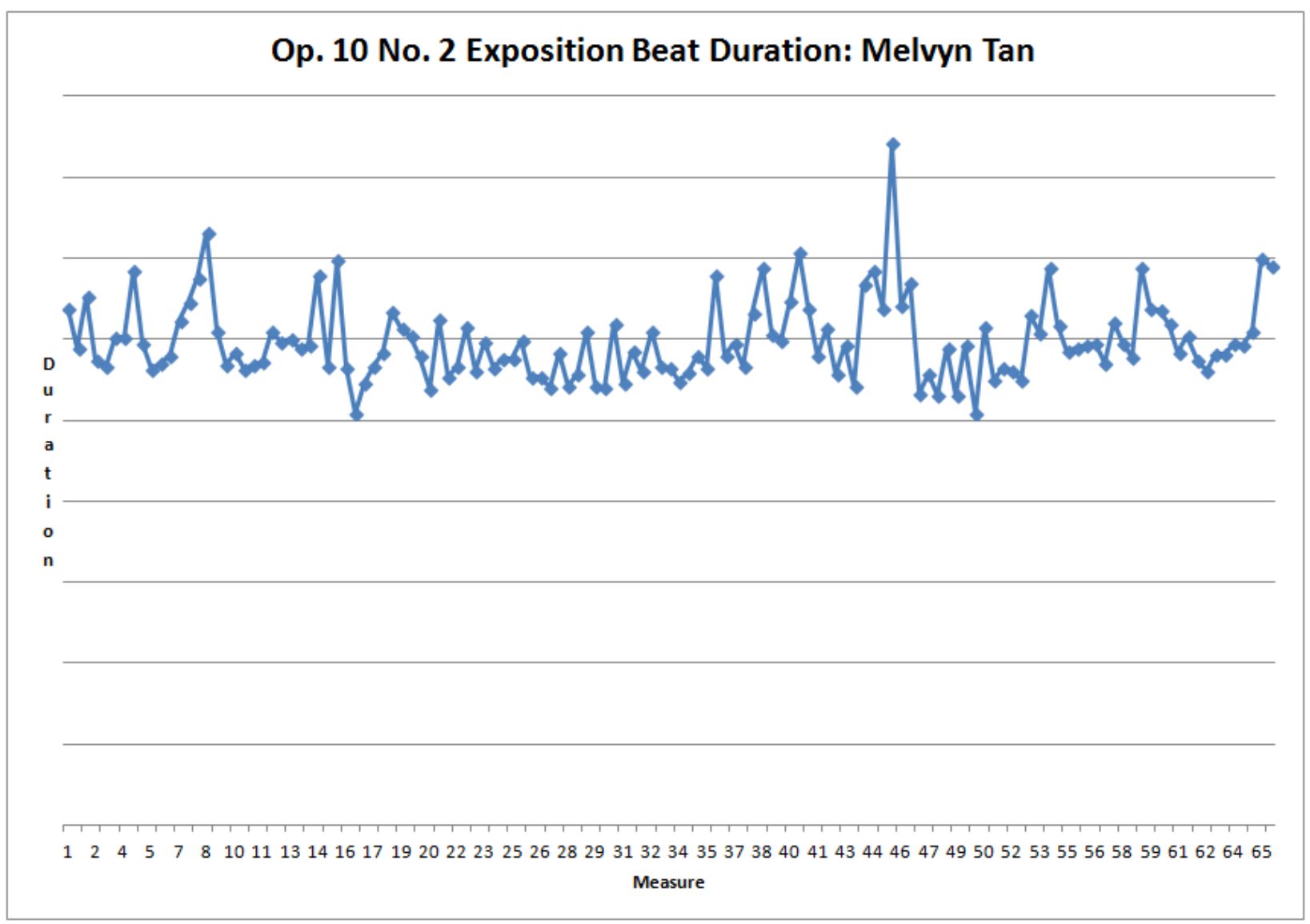


Table 8: Beat Duration Chart, Angela Hewitt (1958-), first movement of Op. 10 No. 2, Exposition

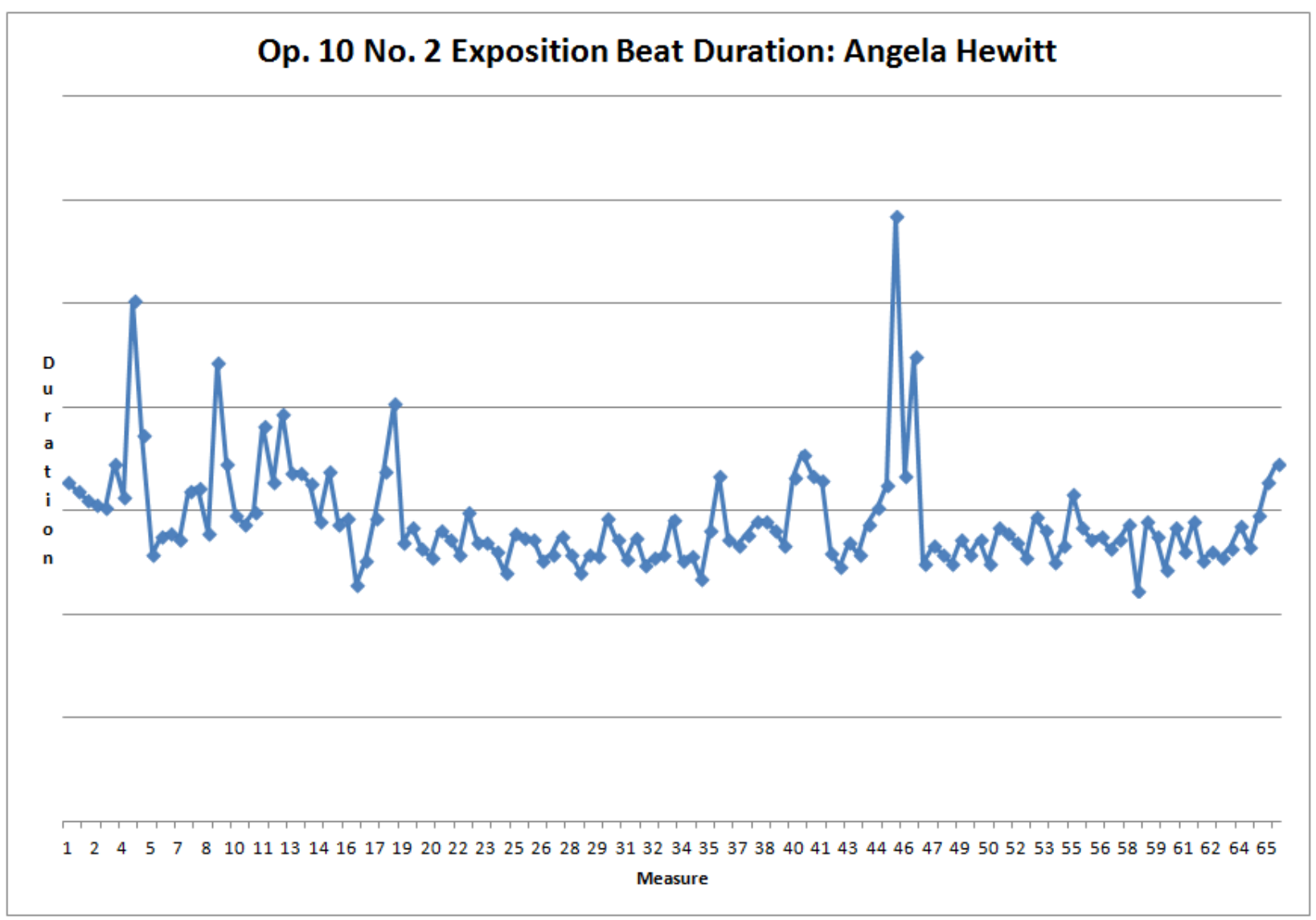


DElia 222

Table 9: Beat Duration Chart, Louis Lottie (1959-), first movement of Op. 10 No. 2, Exposition

Op. 10 No. 2 Exposition Beat Duration: Louis Lottie

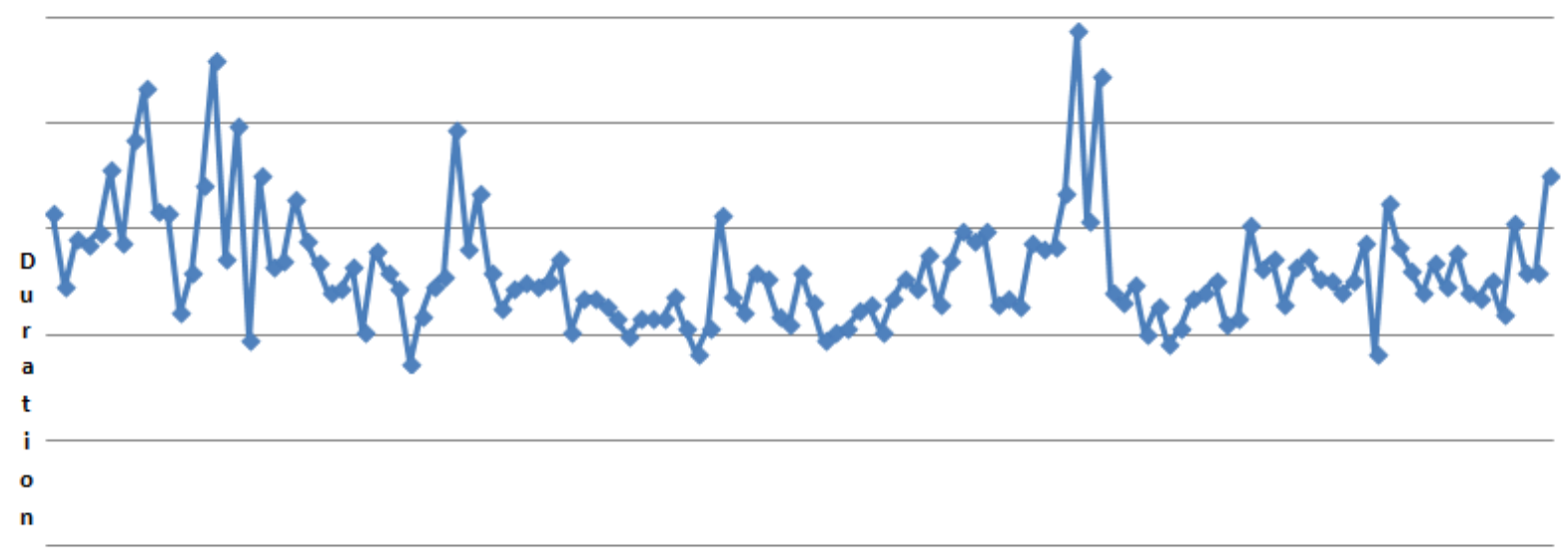

1245781011131416171920222325262829313234353738404143444647495052535556585961626465 
Table 10: Beat Duration Chart, Mikulas Skuta (1960-), first movement of Op. 10 No. 2, Exposition

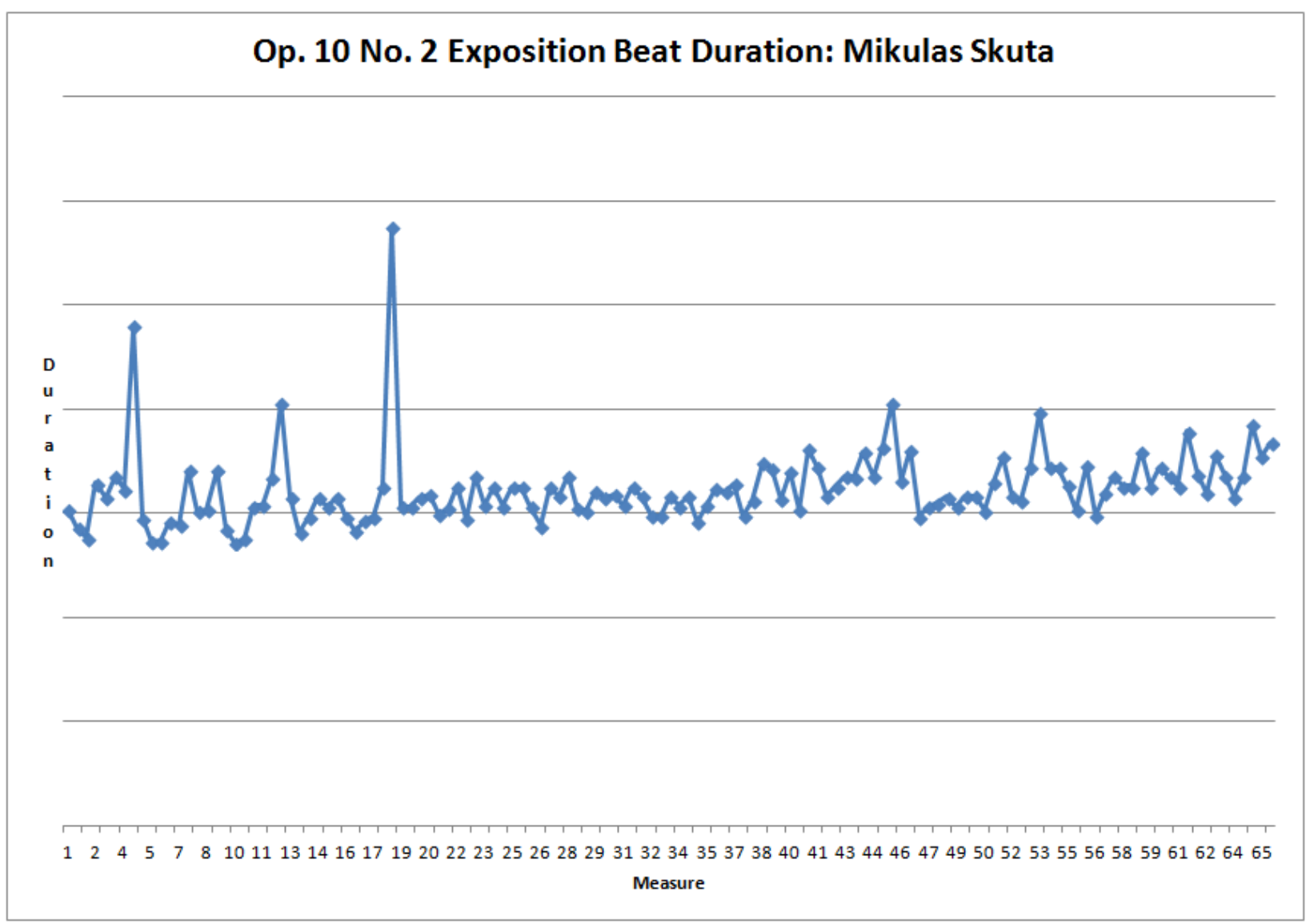


Table 11: Beat Duration Chart, Jean-Efflam Bavouzet (1962-), first movement of Op. 10 No. 2 , Exposition

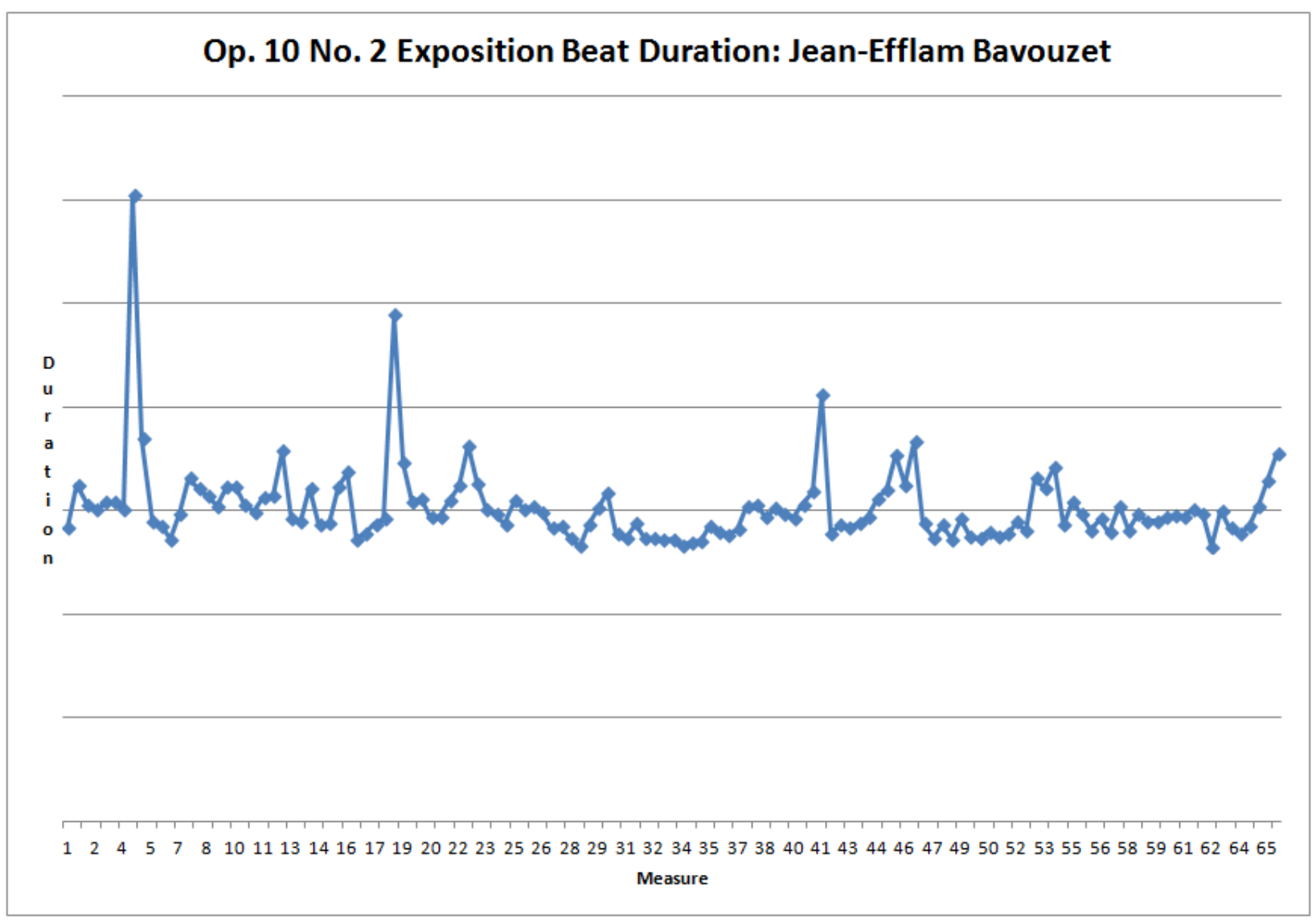


Table 12: Beat Duration Chart, Paul Lewis (1972-), first movement of Op. 10 No. 2, Exposition

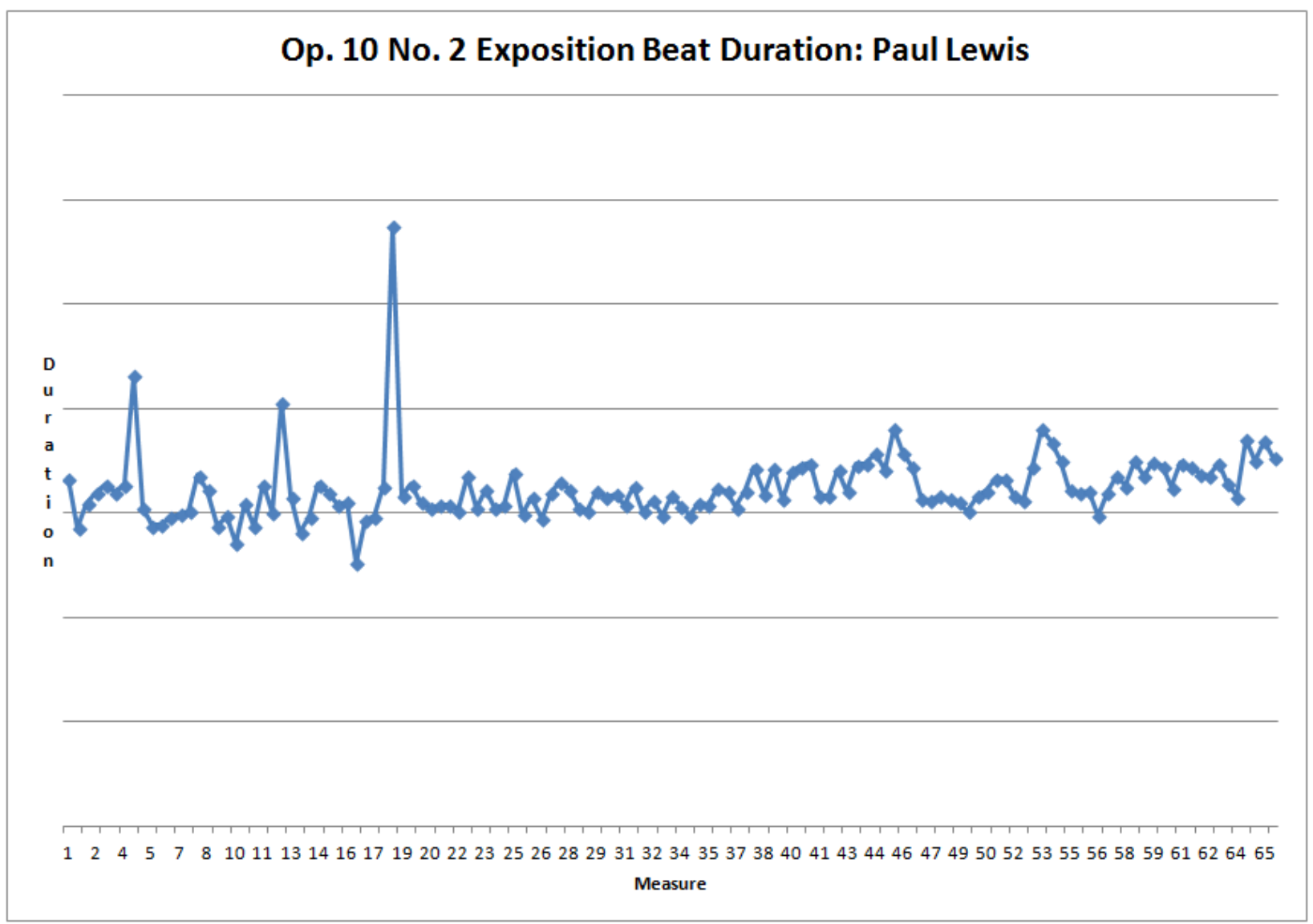




\section{Primary Sources}

Anderson, Emily, translator. Letters. New York: Saint Martin’s Press, 1961.

Baker, Nancy, and Thomas Christensen. Aesthetics and the Art of Musical Composition in the German Enlightenment: Selected Writings of Johann Georg Sulzer and Heinrich Christoph Koch. Cambridge: Cambridge University Press, 1995.

Bernstein, J.M., editor. Classic and Romantic German Aesthetics. Cambridge: Cambridge University Press, 2003.

Burke, Edmund. Reflections on the Revolution in France. Penguin Classics, 1986.

Eichendorff, Joseph von. Sämtliche Werke: Historisch-kritische Ausgabe, edited by Wolfram Mauser. Regensburg: Habbel, 1962.

Goethe, Johann Wolfgang von. The Maxims and Reflections of Goethe, translated by Bailey Saunders. New York: Macmillan, 1906.

Graun, Carl Heinrich. Der Tod Jesu, edited by Howard Serwer. Madison: A-R Editions, 1975.

Hamann, Johann Georg. Briefwechsel, edited by Walther Ziesemer and Arthur Henkel. 8 volumes. Wiesbaden/ Frankfurt: Insel Verlag, 1955-1975.

Hamann, Johann Georg. Writings on Philosophy and Language. Kenneth Haynes, editor. Cambridge: Cambridge University Press, 2007.

Heine, Heinrich. Die romantische Schule, Kritische Ausgabe, H. Weidmann, editor. Stuttgart, 1976.

Koch, Heinrich Christoph. Musikalisches Lexikon, vol. 2. Frankfort am Main: Bey A. Hermann dem Jungern, 1802.

Ruge, Arnold. "Plan der Deutsch-französische Jahrbücher,” in Werke. Mannheim, 1848.

Schlegel, Friedrich. Kritische Friedrich-Schlegel Ausgabe. München: F. Schöningh, 1958.

Senner, Wayne M., Robin Wallace, and William Meredith, editors. The Critical Reception of Beethoven by His German Contemporaries, Vol. I. Lincoln: University of Nebraska Press, 1999.

Sulzer, Johann Georg. Allgemeine Theorie der Schönen Künste, Volume 2. Leipzig: M.G. Weidmann, 1773-75. 
Tieck, Ludwig. Der gestiefelte Kater, edited and translated by Gerald Gillespie. Austin: University of Texas Press, 1974.

Unger, Rudolph. Hamann und die Aufklärung. Jena: Eugen Diederichs, 1911.

\section{Secondary Sources}

Armenteros, Carolina, and Richard A. Lebrun, editors. Joseph de Maistre and the Legacy of the Enlightenment. Oxford: Voltaire Foundation, 2011.

Barr, Raymond A. "Krause," in Grove Music Online.

Barth, George. The Pianist as Orator: Beethoven and the Transformation of Keyboard Style. Cornell University Press: Ithaca, NY, 1992.

Beiser, Frederick C. Enlightenment, Revolution, Romanticism: The Genesis of Modern German Political Thought, 1790-1800. Cambridge: Harvard University Press, 1992.

Beiser, Frederick C. The Fate of Reason: German Philosophy from Kant to Fichte. Cambridge: Harvard University Press, 1987.

Berlin, Isaiah. The Magus of the North: J.G. Hamann and the Origins of Modern Irrationalism. London: John Murray, 1993.

Beghin, Tom, and Sander Goldberg, editors. Haydn and the Performance of Rhetoric. Chicago: University of Chicago Press, 2007.

Betz, John. After Enlightenment: The Post-Secular Vision of J.G. Hamann. Malden, MA: WileyBlackwell Pub., 2009.

Blom, Eric. Beethoven's Pianoforte Sonatas Discussed, unabridged republication of the first edition published in 1938. New York: Da Capo Press, 1968.

Bodley, Lorraine Byrne. Schubert's Goethe Settings. Surrey, England: Ashgate, 2003.

Bonds, Mark Evan. "Rhetoric versus Truth: Listening to Haydn in the Age of Beethoven," in Haydn and the Performance of Rhetoric, edited by Tom Beghin and Sander M. Goldberg. Chicago: University of Chicago Press, 2007.

Bonds, Mark Evan. "Idealism and the Aesthetics of Instrumental Music at the Turn of the Nineteenth Century," Journal of the American Musicological Society 50/2-3 (SummerFall, 1997): 387-420. 
Bowen, José. "The History of Remembered Innovation: Tradition and Its Role in the Relationship Between Musical Works and Their Performances," Journal of Musicology 11/2 (Spring 1993): 139-73.

Boyle, Nicholas. Goethe: The Poet and the Age, Volume 1. Oxford: Clarendon Press, 1991.

Brown, Jane. "In the Beginning was Poetry," in The Cambridge Companion to the Lied, edited by James Parsons, 12-32. Cambridge: Cambridge University Press, 2004.

Burnham, Scott. "The Four Ages of Beethoven: Critical Reception and the Canonic Composer," in The Cambridge Companion to Beethoven, edited by Glenn Stanley, 272-91. Cambridge: Cambridge University Press, 2000.

Chua, Daniel. Absolute Music and the Construction of Meaning. Cambridge: Cambridge University Press, 1999.

Cook, Nicholas. Beyond the Score: Music as Performance. New York: Oxford University Press, 2013.

Cook, Nicholas. "The Ghost in the Machine,” Musicae Scientiae XIV/2 (Fall 2010): 3-21.

Cook, Nicholas. "Squaring the Circle: Phrase Archings in Recordings of Chopin's Mazurkas." Musica Humana I/1 (Spring 2009): 5-28.

Cooper, Barry, editor. The Beethoven Compendium. New York: Thames and Hudson, 1992.

Cooper, Barry. "Beethoven's Oratorio and the Heiligenstadt Testament," The Beethoven Journal 10/1 (Spring 1995): 19-24.

Dahlhaus, Carl. The Idea of Absolute Music, translated by Roger Lustig. Chicago: University of Chicago Press, 1989.

Daverio, John. "Dahlhaus's Beethoven and the Esoteric Aesthetics of the Early Nineteenth Century." Beethoven Forum 2/1 (1993): 189-204.

Dittrich, Marie-Agnes. "The Lieder of Schubert," in The Cambridge Companion to the Lied, edited by James Parsons, 83-100. Cambridge: Cambridge University Press, 2004.

Feder, Georg. "Decline and Restoration," translated by Reinhard G. Pauly, in Protestant Church Music, edited by Friedrich Blume, 319-404. New York: W.W. Norton, 1974.

Forbes, Elliot. Thayer's Life of Beethoven, Volume I. Princeton: Princeton University Press, 1967. 
Frogley, Alain. "Beethoven's Music in Performance: Historical Perspectives," in The Cambridge Companion to Beethoven, edited by Glenn Stanley, 255-71. Cambridge: Cambridge University Press, 2000.

Garrard, Graeme. Rousseau's Counter-Enlightenment: A Republican Critique of the Philosophes. Albany: State University of New York, 2003.

Glauert, Amanda. "The Lieder of Carl Philipp Emanuel Bach, Haydn, Mozart, and Beethoven," in The Cambridge Companion to the Lied, edited by James Parson, 63-84. Cambridge: Cambridge University Press, 2004.

Green, Jeffrey E. "Two Meanings of Disenchantment: Sociological Condition vs. Philosophical Act-Reassessing Max Weber's Thesis of the Disenchantment of the World," Philosophy \& Theology 17 1/2 (2005): 51-84.

Griffith-Dickson, Gwen. "Johann Georg Hamann." The Stanford Encyclopedia of Philosophy (Summer 2013 Edition), Edward N. Zalta (ed.), URL = $<$ http://plato.stanford.edu/archives/sum2013/entries/hamann/>.

Grout, Donald J., Claude V. Palisca, and J. Peter Burkholder, editors. A History of Western Music, 7th edition. New York: W.W. Norton, 2006.

Head, Matthew. "Beethoven Heroine: A Female Allegory of Music and Authorship in Egmont," $19^{\text {th }}$-Century Music 30/2 (Fall 2006): 97-132.

Kinderman, William. Beethoven. Berkeley: University of California Press, 1995.

Kinderman, William. “Beethoven's High Comic Style in Piano Sonatas of the 1790s, or Beethoven, Uncle Toby, and the "Muckcart-driver." Beethoven Forum 5 (1996): 119-38.

Kramer, Richard A. "Beethoven and Carl Heinrich Graun," in Beethoven Studies, edited by Alan Tyson, Volume I, 18-44. New York: W.W. Norton, 1974.

Leech-Wilkinson, Daniel. "Recordings and Histories of Performance Style." in The Cambridge Companion to Recorded Music, edited by Nicholas Cook et al, 246-62. Cambridge: Cambridge University Press, 2009.

Linden, Walther. "Umwertung der deutschen Romantik," Zeitschrift für Deutschkunde 47(1933): 243-75.

Littlejohns, Richard. "Crossing a Threshold: The Example of German Romanticism," in Schwellen: Germanistische Erkundungen einer Metapher, edited by N. Saul, D. Steuer, and F. Möbus, 152-63. Würzburg: Königshausen \& Neumann, 1999. 
Littlejohns, Richard. "Early Romanticism," in The Literature of German Romanticism, edited by Dennis F. Mahoney, 61-78. Rochester, NY: Camden House, 2004.

Lockwood, Lewis. "Beethoven, Florestan, and the Varieties of Heroism," in Beethoven and His World, edited by Scott Burnham and Michael P. Steinberg, 27-47. Princeton: Princeton University Press, 2000.

Lovejoy, A.O. "The Meaning of Romanticism for the Historian of Ideas," Journal of the History of Ideas 2/3 (June 1941): 257-78.

Luntz, George E. Musical and Literary Expression in Songs from Goethe's Wilhelm Meister. Ph.D. dissertation, State University of Iowa, 1953.

Lyons, Sara. "The Disenchantment/Re-Enchantment of the World: Aesthetics, Secularization, and the Gods of Greece from Friedrich Schiller to Walter Pater." The Modern Language Review 109/4 (October 2014): 873-95.

Mali, Joseph, et al. "Isaiah Berlin's Counter-Enlightenment," Transactions of the American Philosophical Society 93/5 (2003).

Malinowski, Bernadette. "German Romantic Poetry in Theory and Practice: The Schlegel Brothers, Schelling, Tieck, Novalis, Eichendorff, Brentano, and Heine," in The Literature of German Romanticism, edited by Dennis F. Mahoney, 147-70. Rochester, NY: Camden House, 2004.

Marshall, Robert L. and Diane M. McMullen, "Sperontes," in Grove Music Online.

Mathew, Nicholas. Political Beethoven. Cambridge: Cambridge University Press, 2013.

McMahon, Darrin. Enemies of the Enlightenment: The French Counter-Enlightenment and the Making of Modernity. New York: Oxford University Press, 2001.

Morrow, Mary Sue. German Music Criticism in the Late Eighteenth Century: Aesthetic Issues in Instrumental Music. Cambridge: Cambridge University Press, 1997.

Norton, Robert E. "The Myth of the Counter-Enlightenment," Journal of the History of Ideas 68/4 (October 2007): 635-58.

Ottenberg, Hans-Gunter. “Zelter, Carl Friedrich,” Grove Music Online.

Parsons, James. "The Eighteenth-Century Lied," in The Cambridge Companion to the Lied, edited by James Parsons, 33-62. Cambridge: Cambridge University Press, 2004.

Parsons, James. "Lieder c. 1740-1800" in The New Grove Online. 
Peter, Klaus. "History and Moral Imperatives: The Contradictions of Political Romanticism," in The Literature of German Romanticism, edited by Dennis F. Mahoney, 191-208. Rochester, NY: Camden House, 2004.

Philip, Robert. Early Recordings and Musical Style: Changing Tastes in Instrumental Performance, 1900-1950. Cambridge: Cambridge University Press, 1992.

Reed, T.J. “The 'Goethezeit,' and its Aftermath," in Germany: A Companion to German Studies, edited by Malcolm Pasley, 493-553. London: Methuen, 1972.

Réti, Rudolph. Thematic Patterns in Sonatas of Beethoven. New York: Macmillan Co., 1967.

Rink, John, Neta Spiro, and Nicolas Gold. "The Form of Performance: Analyzing Pattern Distribution in Select Recordings of Chopin's Mazurka Op. 24 No. 2," Musicae Scientiae XIV/2 (Fall 2010): 23-55.

Charles Rosen, Beethoven's Piano Sonatas: A Short Companion. New Haven: Yale University Press, 2002.

Rosen, Charles. The Classical Style: Haydn, Mozart, Beethoven. New York: The Viking Press, 1971.

Rumph, Stephen. Beethoven after Napoleon: Political Romanticism in the Late Works. Berkeley: University of California Press, 2004.

Sams, Eric. "Lied," Grove Music Online.

Saul, Nicholas. "Aesthetic Humanism (1790-1830)," in The Cambridge History of German Literature, edited by Helen Watanabe-O'Kelly, 202-71. Cambridge: Cambridge University Press, 1997.

Schmidt, James. "Enlightenment as Concept and Context." Journal of the History of Ideas 75/4 (October 2014): 677-85.

Schroeder, David P. "Haydn and Gellert: Parallels in Eighteenth-Century Music and Literature." Current Musicology 35 (1983): 7-18.

Schultz, Gerhard. "The Genesis of German Romanticism," in The Literature of German Romanticism, edited by Dennis F. Mahoney, 25-34. Rochester, NY: Camden House, 2004.

Seelig, Harry. "The Literary Context: Goethe as Source and Catalyst," in German Lieder in the Nineteenth Century, second edition, edited by Rufus Hallmark, 1-34. New York: Routledge, 2010. 
Seyhan, Azade. "What is Romanticism, and Where did it Come From?" In The Cambridge Companion to German Romanticism, edited by Nicholas Saul, 1-20. Cambridge: Cambridge University Press, 2009.

Small, Christopher. Musicking: The Meanings of Performing and Listening. Hanover, NH: University Press of New England, 1998.

Solie, Ruth. "Beethoven as a Secular Humanist: Ideology and the Ninth Symphony in Nineteenth-Century Criticism." In Explorations of Music, the Arts, and Ideas: Essays in Honor of Leonard B. Meyer, edited by Eugene Narmour and Ruth A. Solie, 1-42. Stuyvesant, NY: Pendragon Press, 1988.

Stone, Alison. "Alienation from Nature and Early German Romanticism," Ethical Theory and Moral Practice 17 (2014): 41-54.

Smither, Howard. A History of the Oratorio, Volume 3: The Oratorio in the Classical Era. Chapel Hill: The University of North Carolina Press, 1987.

Smither, Howard. "Oratorio." Grove Music Online.

Solomon, Maynard. Beethoven, $2^{\text {nd }}$ edition. New York: Schirmer Books, 1998.

Solomon, Maynard. "Beethoven: Beyond Classicism," in The Beethoven Quartet Companion, edited by Robert Winter and Robert Martin, 59-76. Berkeley: University of California Press, 1994.

Sparling, Robert Alan. Johann Georg Hamann and the Enlightenment Project. Toronto: University of Toronto Press, 2011.

Swafford, Jan. Beethoven: Anguish and Triumph. New York: Houghton Mifflin Harcourt, 2014.

Taruskin, Richard. Text and Act: Essays on Music and Performance. New York: Oxford University Press, 1995.

Taub, Robert. Playing the Beethoven Piano Sonatas. Portland, OR: Amadeus Press, 2002.

Taylor, Charles. A Secular Age. Cambridge: The Belknap Press of Harvard University Press, 2007.

Thalmann, Marianne. Ludwig Tieck: der romantische Weltmann aus Berlin. Bern: Francke, 1955.

Todd, Neil. "The Dynamics of Dynamics: A Model of Musical Expression," Journal of the Acoustical Society of America 91 (1992): 3540-50 
Tovey, Donald Francis. A Companion to Beethoven's Pianoforte Sonatas. London: Associated Board of the R.A.M. and the R.C.M., 1931.

Volioti, Georgia. "Playing with Tradition: Weighing up Similarity and the Buoyancy of the Game. Musicae Scientiae: The Journal of the European Society for the Cognitive Sciences of Music XIV/2 (Fall 2010): 85-114.

Weber, Max. "Science as a Vocation," in From Max Weber: Essays in Sociology, edited by H.H. Gerth and C. Wright Mills, 129-56. Abingdon, England: Routledge, 1991.

Webster, James. "Haydn: Style,” Grove Music Online.

Will, Richard. The Characteristic Symphony in the Age of Haydn and Beethoven. Cambridge: Cambridge University Press, 2002.

Youens, Susan. "Franz Schubert: The Lied Transformed," in German Lieder in the Nineteenth Century, second edition, edited by Rufus Hallmark. New York: Routledge, 2010.

Youngren, William H. C.P.E. Bach and the Rebirth of Strophic Song. Lanham, MD: Scarecrow Press, 2003.

Zohn, Steven. "Georg Philipp Telemann: Secular Vocal Music," in Grove Music Online. 